Portland State University

PDXScholar

Spring 4-11-2018

\title{
Combined Theoretical and Experimental Investigation of Hydrogen Production Catalysis
}

Carolyn Noelle Virca

Portland State University

Follow this and additional works at: https://pdxscholar.library.pdx.edu/open_access_etds

Part of the Chemistry Commons

Let us know how access to this document benefits you.

Recommended Citation

Virca, Carolyn Noelle, "Combined Theoretical and Experimental Investigation of Hydrogen Production Catalysis" (2018). Dissertations and Theses. Paper 4384.

https://doi.org/10.15760/etd.6268

This Dissertation is brought to you for free and open access. It has been accepted for inclusion in Dissertations and Theses by an authorized administrator of PDXScholar. Please contact us if we can make this document more accessible: pdxscholar@pdx.edu. 
Combined Theoretical and Experimental Investigation of Hydrogen Production

Catalysis

by

Carolyn Noëlle Virca

A dissertation submitted in partial fulfillment of the requirements for the degree of

Doctor of Philosophy

in

Chemistry

Dissertation Committee:

Theresa McCormick, Chair

Dave Stuart

Rob Strongin

Jun Jiao

Portland State University

2018 


\begin{abstract}
The widespread use of solar energy has been limited in part by the issue of effective storage. Water splitting is a means of converting solar energy into chemical fuel, in the form of hydrogen gas. It can be performed through both photochemical and electrochemical processes, via the two half reactions of water oxidation and proton reduction. Electrochemically, the catalyst receives electrons from an external circuit, which can be coupled to a renewable source such as a solar cell. Photochemically, a light-absorbing molecule provides an excited electron to a catalyst, which either generates oxygen or hydrogen gas. The work described herein studies both photochemical and electrochemical proton reduction using two different systems made of inexpensive transition metal and organic components.
\end{abstract}

Nickel pyridine 2-thiolate $\left(\mathrm{Ni}(\mathrm{PyS})_{3}{ }^{-}\right) \quad(\mathrm{PyS}=$ pyridinthiolate $)$ has been demonstrated to have good stability and activity as a proton reduction catalyst. It is applied here as an electrocatalyst, due to the wealth of mechanistic information that can be obtained through electrochemical experiments. In our study of $\mathrm{Ni}(\mathrm{PyS})_{3}{ }^{-}$, a previously proposed catalytic pathway was first supported through Density Functional Theory (DFT) computations. Thermodynamic properties of the molecular nickel compound were investigated through analysis of free energy changes along various reaction coordinates, spin states, localization of charge and geometry of the intermediates and transition states. An experimental and theoretical investigation of the effects of ligand modification on hydrogen production and the catalytic mechanisms was then undertaken. 
Six derivatives of $\mathrm{Ni}(\mathrm{PyS})_{3}{ }^{-}$were synthesized through uniform ligand modification to all three $\mathrm{PyS}^{-}$ligands using a series of electron rich or poor substituents. The physical properties of interest were investigated experimentally through electrochemical methods and UV-vis absorbance spectroscopy. Specifically, the desired properties for a hydrogen production catalyst are high proton affinity, quantified through the $\mathrm{p} K_{a}$, and low overpotential, quantified through $\mathrm{E}^{0}$. Each compound was also studied in depth using computational modeling of the various possible catalytic pathways. By combining the results of computational study with experimental results, mechanistic insight could be gained. Electron poor catalysts maintained the normal mechanism undergone by the unmodified $\mathrm{Ni}(\mathrm{PyS})_{3}{ }^{-}$catalyst, but these compounds also yielded low electrochemical hydrogen production rates. The highest rate of hydrogen production was noted for the most electron rich catalyst, which was found to proceed through a unique mechanism. Ultimately, its unique mechanism was attributed to favorable changes to its physical properties.

The same joint theoretical and experimental methodology has been used to study the effect of non-uniform ligand modification. Four heteroleptic compounds were selected for study, two containing electron poor ligands and two containing electron rich ligands in varied ratios. It was hypothesized that an appropriate ligand combination could target the desired properties necessary to increase hydrogen production rates. Catalysts were designed keeping in mind that more electron rich ligands were found to correlate with higher proton affinity, while electron poor ligands were found to promote lower overpotentials. By making heteroleptic compounds, these two physical properties 
are targeted independently from one another. What is found is that not only do the electronics of each ligand influence physical properties, but the placement of each ligand matters as well. Due to the unique structural features of heteroleptic compounds, the effectiveness of hydrogen production varies greatly. Thorough computational and experiential analysis provides insight into the underlying factors that govern these variations.

Finally, photochemical hydrogen production was performed using polyvinylpyrrolidone (PVP)-coated carbon quantum dots (CQDs) as a photosensitizer, and nickel nanoparticles (NiNPs) as a catalyst. Total hydrogen production by CQD/NiNP composites as a function of the amount of PVP coating was investigated as well as various mechanistic and photophysical properties. Hydrogen production was studied using a custom-made photoreactor and a quadrupole mass analyzer. Both fluorescence quantum yields and hydrogen production quantum yields were determined using a phosphoremeter with an integrating sphere. The mechanism of hydrogen production was probed using fluorescence spectroscopy as well. Finally, an investigation into whether or not CQDs are capable of performing upconversion, as has been previously noted in the literature, was undertaken. The fluorescence quantum yield of the CQDs was found to increase along with increased addition of PVP coating. It was also noted that composites with more PVP had decreased rates of hydrogen production, but it was sustained over a longer period of time. Duel hydrogen production mechanisms were also found to be possible. 


\section{DEDICATION}

This work is dedicated to my parents. 


\section{ACKNOWLEDGEMENTS}

I would like to express my gratitude to my advisor, mentor and committee chair, Dr. Theresa McCormick, and my committee members, Dr. Dave Stuart, Dr. Andrea Goforth, Dr. Rob Strongin, and Dr. Jun Jiao, for guidance, stimulating discussions and generous encouragement throughout the development of this work.

I must also recognize the family I have found within in my lab, and the mentors who have guided me. Graduate school would not have been the same without my friends Austin, Christine, Neal and the rest of the McCormick lab. I have also had the fortune of being guided by a series of strong female mentors who have aided not only in my academic development, but in my personal growth. Thank you to those women, especially Dr. Marilyn Mackiewicz and of course, my advisor Theresa. How fortunate I am that my life led me to you and your lab. It has been an honor being your student.

Finally, my biggest thanks is reserved for my family. Thank you to my parents, for your immeasurable support during the many difficult phases of this journey, and your encouragement and celebration during the highlights. Thank you to my aunt, who was my first strong female mentor, and the first person who told me to "Go get a PhD." Lastly, I must give thanks to my chosen family. Thank you Nick, for being my partner in every sense of the word for the last decade. There is no question that I would not have made it here without you.

This work was supported by my committee consisting of Dr. Theresa McCormick, Dr. David Stuart and Dr. Rob Strongin of the Department of Chemistry and 
Dr. Jun Jiao of the College of Engineering. Dr. Andrea Goforth also acted as a committee member previously and offered support, input and guidance.

Austin Shigemoto acquired all of the mass spectra in Chapters 4 and 5. ICPMS was performed by Dr. Martina Ralle at the Oregon Health and Science University. TEM was performed by Dr. Marilyn Mackiewicz at Portland State University. Dr. Edward Valente performed crystallographic measurements at the Univeristy of Portland.

Funding was provided by Portland State University. 
ABSTRACT

.. $\mathbf{i}$

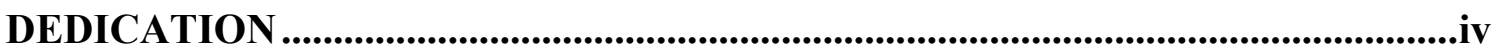

ACKNOWLEDGEMENTS ................................................................................................v

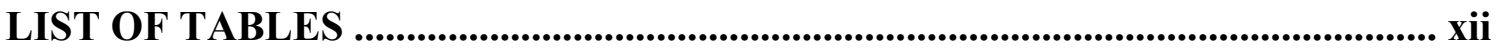

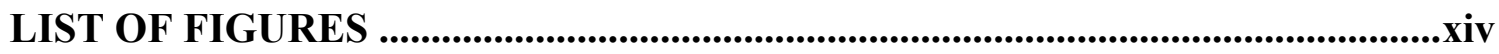

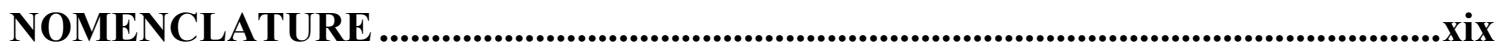

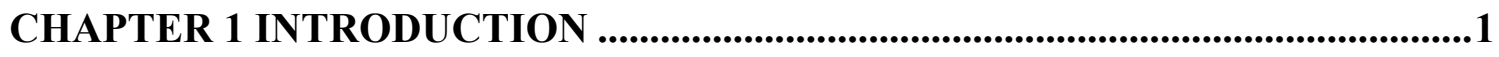

1.1 GLOBAL CONSUMPTION AND PRODUCTION OF ENERGY .............................

1.2 CONVERSION OF SOLAR ENERGY USING PHOTOVOLTAICS ...........................2

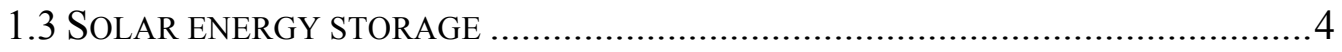

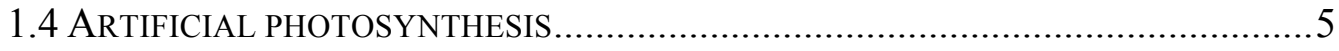

1.5 ELECTROCHEMICAL WATER SPLITTING ..................................................

1.5.1. Molecular electrocatalysis using transition metal proton reduction

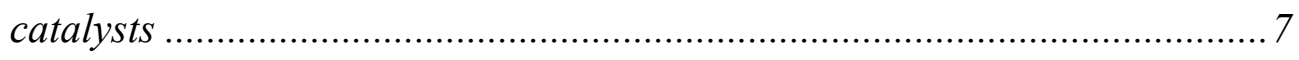

1.5.2. Electrocatalytic proton reduction using $\mathrm{Ni}(\mathrm{PyS})_{3}{ }^{-} \ldots \ldots \ldots \ldots \ldots \ldots \ldots \ldots . . . . . . . . . . .11$

1.6 PHOTOCHEMICAL WATER SPLITTING ................................................... 12

1.6.3. Quantum dot sensitizers for photochemical water splitting..............17

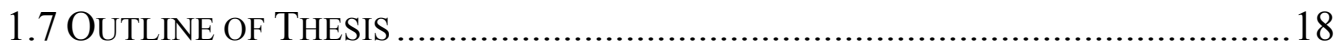

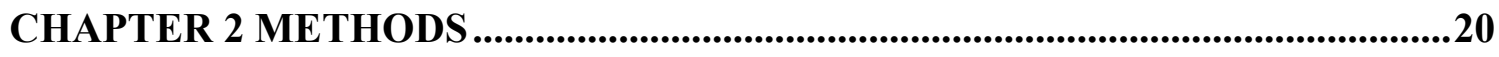

vii 


\subsection{EXPERIMENTAL AND COMPUTATIONAL METHODS TO STUDY}

ELECTROCATALYTIC PROTON REDUCTION .20

2.1.1. Computational determination of thermodynamic properties.... 20

2.1.2. Experimental determination of reduction potentials and rates of hydrogen production using cyclic voltammetry

2.1.3. Experimental determination of $p K a$ values using $U V$-vis spectroscopy

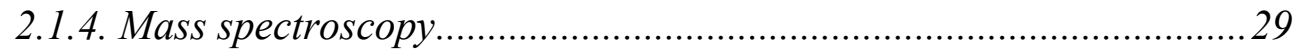

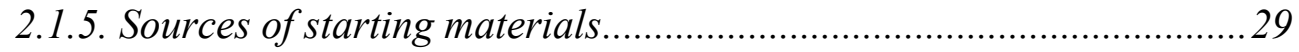

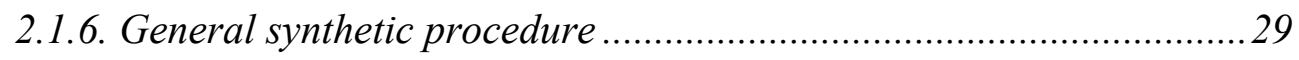

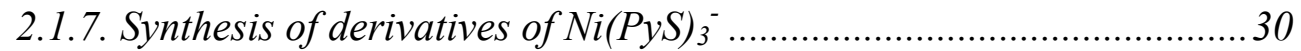

2.2 EXPERIMENTAL METHODS TO STUDY PHOTOCATALYTIC PROTON REDUCTION

2.2.8. Experimental conditions for photochemical hydrogen production ....39

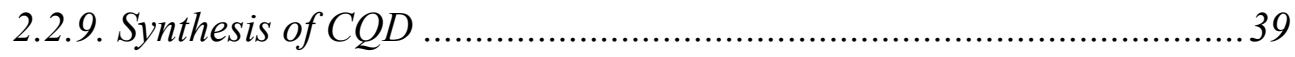

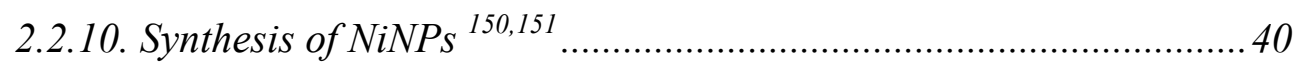

2.2.11. Transmission Electron Microscopy and EDX.............................41

2.2.12. Fluorescence Quantum Yield Measurements ................................41

2.2.13. Fluorescence quenching studies..............................................42

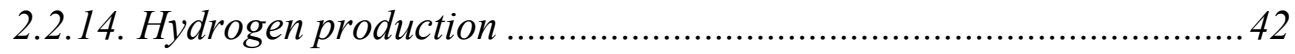

CHAPTER 3 INITIAL COMPUTATIONAL INVESTIGTION OF NICKEL

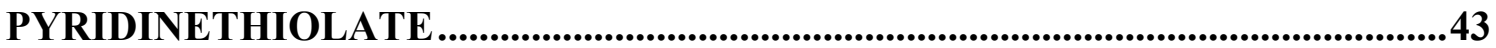

viii 
DFT ANALysis INTO THE INTERMEDIATES OF NiCKel PyRIDINETHIOLATE

CATALYZED PROTON REDUCTIONS ..................................................................

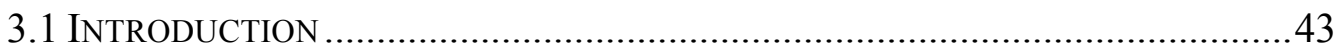

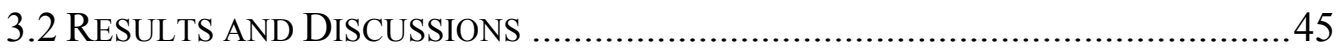

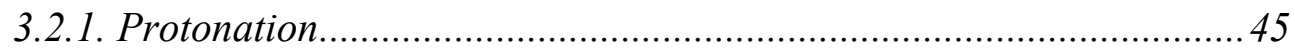

3.2.2. Geometry and Water Coordination ………......................................48

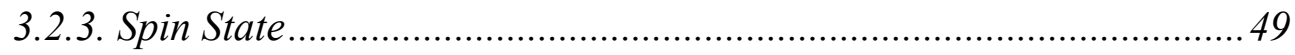

3.2.4. Hydride Formation.......................................................................... 51

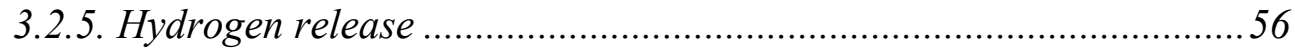

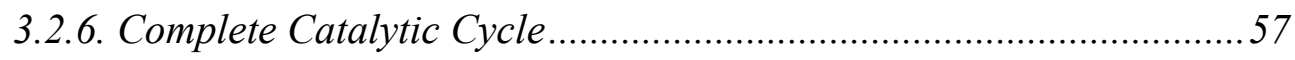

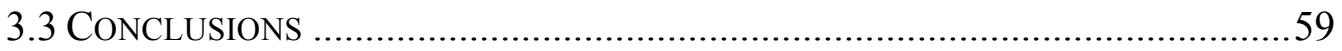

\section{CHAPTER 4 MODIFICATION OF PYRIDINETHIOLATE LIGANDS ................61}

INVESTIGATION INTO THE EFFECT OF LIGAND MODIFICATION ON DERIVATIVES OF A NI(PYS $)_{3}{ }^{-}$PROTON REDUCTION CATALYST USING JOINT COMPUTATIONAL AND

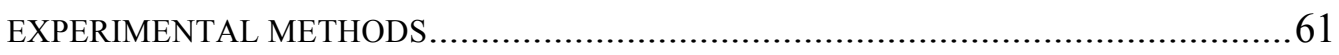

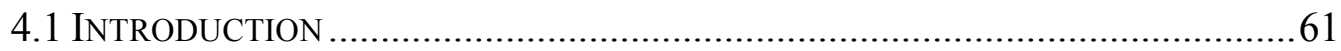

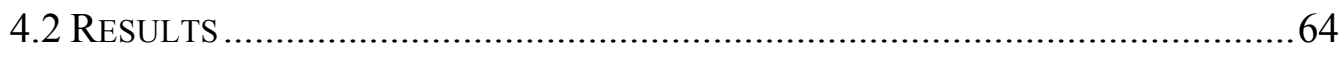

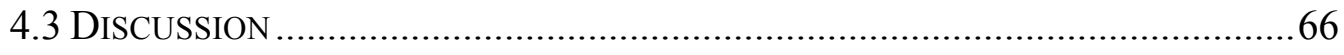

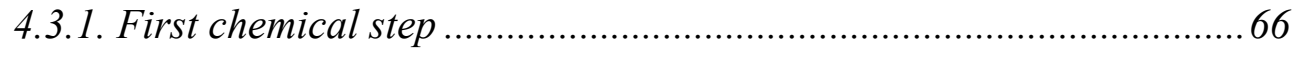

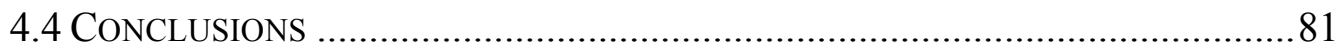

CHAPTER 5 HETEROLEPTIC MODIFICATION OF NICKEL

PYRIDINETHIOLATE ......................................................................................................82 
UNEXPECTED STRUCTURAL EFFECTS OF HETEROLEPTIC CATALYST DESIGN .......82

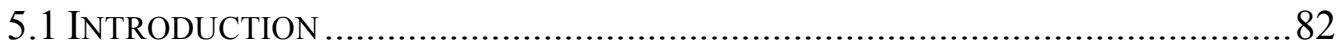

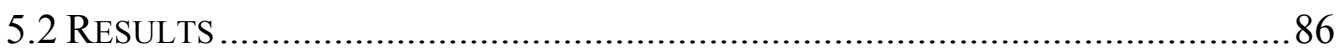

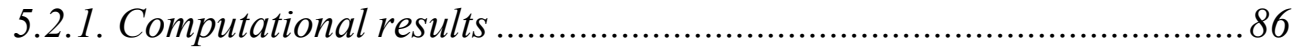

5.2.2. Experimental results............................................................... 94

5.2.3. $U V$-vis absorbance spectroscopy ........................................... 96

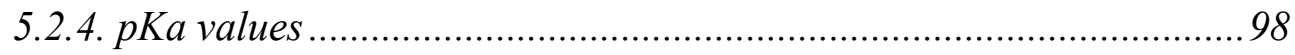

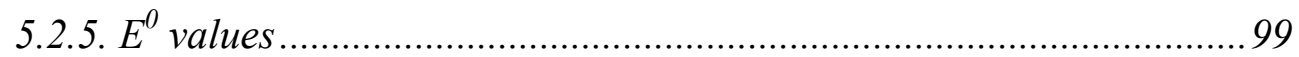

5.2.6. Electrochemical rates of hydrogen production .............................100

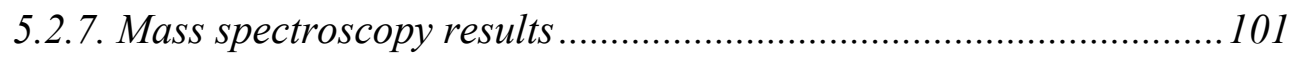

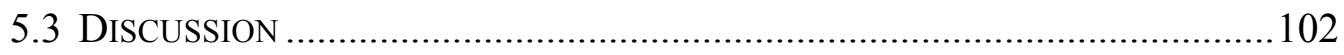

5.3.8. Support for formation of heteroleptic compounds ....................... 102

5.3.9. Effects of isomers on catalytic properties and effectiveness of

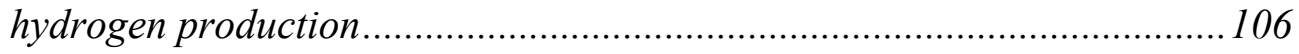

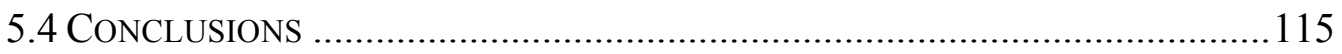

CHAPTER 6 PHOTOCHEMICAL CONVERSION OF SOLAR ENERGY ........118

Photocatalytic Water Reduction Using a Polymer Coated Carbon

Quantum Dot Sensitizer and a Nickel Nanoparticle CATAlyst ...........118

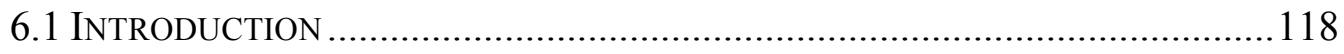

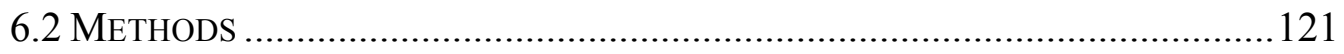

6.2.1. Potassium Ferrioxalate Actinometry ${ }^{146}$......................................... 121

6.2.2. CQD Composition and Morphology ......................................... 124 
6.2.3. Photoluminescence of PVP Coated CQDs

6.2.4. Hydrogen Production Using CQD Sensitizers and NiNP Catalysts.

6.2.5. Mechanistic Investigation via Fluorescence Quenching Titrations. 135

6.3 CONCLUSIONS .

CHAPTER 7 CONCLUSIONS

A MULTIFACETED APPROACH TO UNDERSTANDING SOLAR ENERGY CONVERSION

SYSTEMS

REFERENCES 146

APPENDIX ADDITIONAL EXPERIMENTAL AND COMPUTATIONAL DATA

180 


\section{LIST OF TABLES}

Table 2-1: Calculated bond lengths vs crystal structure bond lengths for different basis sets and levels of theories.

Table 2-2: Calculated error for computed bond lengths.

Table 4-1: Specified substitutions on $\mathrm{Ni}(\mathrm{PyS})_{3}{ }^{-}$schematic with associated Hammett constants. $^{189}$

Table 4-2: Computationally determined $\mathrm{p} K_{a}^{\mathrm{t}}$ values and reduction potentials* (V vs $\mathrm{SCE})$ with experimental $\mathrm{p} K_{a}$ 's, reduction potentials, TOFs and overpotentials $\left(\eta_{\text {exp }}\right)$.

Table 4-3: Second $\mathrm{p} K_{a}$ (with location of protonation) and second reduction potential (V vs SCE).

Table 5-1: Relative population for the three isomers of each heteroleptic compound determined from the energies of formation of each isomer.....

Table 5-2: $\mathrm{p} K_{a}$ values for protonation at each of the labeled ligand positions for the three isomers of each heteroleptic compound. Cells highlighted in red indicate ligands with electron withdrawing modification and cells highlighted in green indicate ligands with electron donating modifications....90

Table 5-3: Average values for $\mathrm{p} K_{a}$ and $\mathrm{E}^{0}$ values for corresponding numbered chemical $\left(C_{1}\right.$ and $\left.C_{2}\right)$ or electrochemical $\left(E_{1}\right.$ and $\left.E_{2}\right)$ steps. Specific sites of protonation are indicated.

Table 5-4: Reduction potentials for isomers of each heteroleptic compound. Columns indicate which ligand was protonated in the previous step. Only compounds with $\mathrm{p} K_{a}$ values greater than 5 were considered. Cells highlighted in red indicate ligands with electron withdrawing modification and cells highlighted in green indicate ligands with electron donating modifications....92

Table 5-5: Measured $\lambda_{\max }$ values for each heteroleptic complex in both acidic and basic conditions. Absorbance values in the visible region corresponding to $\mathrm{d}$ to $\mathrm{d}$ transitions included as well.

Table 5-6: Values for $\mathrm{E}^{0}$ and $\mathrm{p} K_{a}$ determined experimentally for homoleptic and heteroleptic compounds. For $\mathrm{Ni}\left(6-\mathrm{CH}_{3} \mathrm{PyS}\right)_{3}{ }^{-}$the reported values are computational values for the CECE mechanism for comparison purposes. ${ }^{\mathrm{e}}$ Indicates experimentally obtained values and ${ }^{c}$ denotes computed values..... 100 
Table 5-7: Mass spectra data for heteroleptic compounds. Each compound tested is highlighted in bold with important fragments listen underneath, along with their expected masses and measured masses.

Table 6-1: Quantum yields $(\Phi)$ for CQDs with various percentage PVP coatings by weight. Quantum yields were measured with $360 \mathrm{~nm}$ excitation and $470 \mathrm{~nm}$ excitation

Table 6-2: Instantaneous rates of $\mathrm{H}_{2}$ production of CQDs with varying polymer coating calculated at $\mathrm{t}=10$ mins and $\mathrm{t}=60 \mathrm{mins}$ using $6 \mu \mathrm{g} / \mathrm{mL}$ of NiNPs and $68 \mu \mathrm{g} / \mathrm{mL}$ of CQDs. Effect of PVP coating by weight percent of CQDs on total $\mathrm{H}_{2}$ production after $5 \mathrm{~h}$ in a total volume of $10 \mathrm{~mL}$. 


\section{LIST OF FIGURES}

Figure 1-1: Comparative scheme of the stored energy in one molecule of glucose vs the stored energy in one molecule of hydrogen gas.

Figure 1-2: A) Electrochemical water splitting scheme B) photochemical water

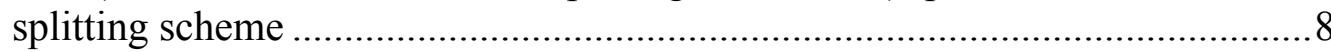

Figure 1-3: Structure of $\mathrm{Ni}(\mathrm{PyS})_{3}^{-}$

Figure 1-4: Integrated water splitting system with both water oxidation and proton reduction. Here two photosensitizers are pictured with conduction and valence bands located at the correct potentials to drive water oxidation ($1.23 \mathrm{~V}$ vs SHE) and proton reduction ( $0.00 \mathrm{~V}$ vs SHE).

Figure 1-5: Scheme of the mechanism of oxidative quenching (left) $v s$ mechanism of reductive quenching (right) for quenching of luminescence due to electron transfer. Circled numbers indicate the order in which each step is occurring. .15

Figure 2-1: Optimized structure of $\mathrm{Ni}(\mathrm{PyS})_{3}{ }^{-}$using A) $\mathrm{B} 3 \mathrm{LYP} /$ gas phase $\left.\mathrm{B}\right) \mathrm{B} 3 \mathrm{LYP} /$ water C) $\mathrm{B} 3 \mathrm{LYP} /$ ethanol D) B3P86/ gas phase E) B3P86/ water F) B3P86/ ethanol.

Figure 2-2: Single crystal X-ray structure obtained for $\mathrm{Ni}(\mathrm{PyS})_{3}\left[\mathrm{Et}_{4} \mathrm{~N}\right]$. Chemical formula: $\mathrm{C}_{23} \mathrm{H}_{32} \mathrm{~N}_{4} \mathrm{NiS}_{3}$. Space group: $\mathrm{P} 2{ }_{1} / \mathrm{c}$ (14). Cell Lengths: a 14.9857(11) b 9.1919(3) c 18.7452(11). Cell angles: a 90.039(4) b 104.865(5) g 90.067(4). Cell volume: 2495.68. Z,Z': Z: 4 Z': 0. RFactor(\%): 3.91 .

Figure 3-1: Proposed catalytic cycle for proton reduction by $\left[\mathrm{Ni}(\mathrm{PyS})_{3}\right]^{-}$with cation omitted.

Figure 3-2: Optimized structures of $\mathrm{Ni}(\mathrm{PyS})_{3} \mathrm{H}^{\mathrm{N}}{ }_{\text {(gas) }}, \mathrm{Ni}(\mathrm{PyS})_{3} \mathrm{H}^{\mathrm{N}}, \quad \mathrm{Ni}(\mathrm{PyS})_{3} \mathrm{H}^{\mathrm{S}}$ and $\mathrm{Ni}(\mathrm{PyS})_{3}{ }^{2-}$. Grey, carbon; Blue, nitrogen; Yellow, sulfur; White, hydrogen; Light Blue, nickel.

Figure 3-3: Energy coordinate diagram at $\mathrm{pH} 12$ of: Green: reduction of $\mathrm{Ni}(\mathrm{PyS})_{3}$; Red: protonation at sulfur followed by reduction; Blue: protonation at pyridyl nitrogen followed by reduction. Optimized structures of both $\mathrm{Ni}(\mathrm{PyS})_{3} \mathrm{H}^{\mathrm{N-}}$ and $\mathrm{Ni}(\mathrm{PyS})_{3} \mathrm{H}^{\mathrm{S}-}$ with doublet spin states.

Figure 3-4: Structure $\mathrm{Ni}(\mathrm{PyS})_{3} \mathrm{H}^{\mathrm{N}} \cdot \mathrm{H}_{2} \mathrm{O}$ optimized in water and in the gas phase and structure $\mathrm{Ni}(\mathrm{PyS})_{3} \mathrm{H}^{\mathrm{N}-} \bullet \mathrm{H}_{2} \mathrm{O}$ optimized using water with a CPCM solvation model. 
Figure 3-5: Optimized structure of $\mathrm{Ni}(\mathrm{PyS})_{3} \mathrm{H}^{\mathrm{N}}$ singlet. Electron spin density map of $\mathrm{Ni}(\mathrm{PyS})_{3} \mathrm{H}^{\mathrm{N}-}$ in the quartet spin state and doublet spin state. Optimized structure of $\mathrm{Ni}(\mathrm{PyS})_{3} \mathrm{H}^{\mathrm{N}-}$ in a quartet spin state....

Figure 3-6: Optimized structures of $\mathrm{Ni}(\mathrm{PyS})_{3} \mathrm{H}^{\mathrm{N}} \mathrm{H}^{\mathrm{Ni}-}$ singlet (gas), $\mathrm{Ni}(\mathrm{PyS})_{3} \mathrm{H}^{\mathrm{N}} \mathrm{H}^{\mathrm{Ni}-}$ singlet

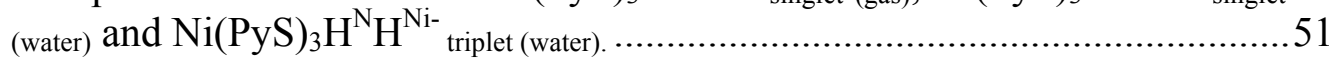

Figure 3-7: PCET alternative intermediates: second reduction, $\mathrm{Ni}(\mathrm{PyS})_{3} \mathrm{H}^{\mathrm{N}}{ }^{2-}$, protonation, $\mathrm{Ni}(\mathrm{PyS})_{3} \mathrm{H}^{\mathrm{N}} \mathrm{H}^{\mathrm{Ni}}$, and reduction with concerted proton migration, $\mathrm{Ni}(\mathrm{PyS})_{3} \mathrm{H}^{\mathrm{Ni} 2-}$.

Figure 3-8: Optimized structures of $\mathrm{Ni}(\mathrm{PyS})_{3} \mathrm{H}^{\mathrm{N}}{ }^{2-}{ }_{\text {singlet, }} \mathrm{Ni}(\mathrm{PyS})_{3} \mathrm{H}^{\mathrm{N}}{ }^{2-}$ triplet,

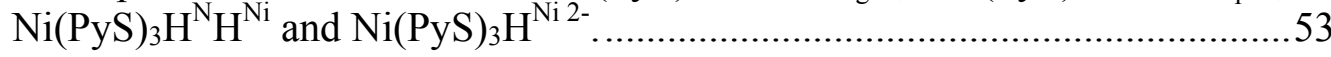

Figure 3-9: Energy coordinate diagram for alternative paths to PCET. Red trace: $\mathrm{Ni}(\mathrm{PyS})_{3} \mathrm{H}^{\mathrm{N}-}$ is first protonated $\left(\mathrm{Ni}(\mathrm{PyS})_{3} \mathrm{H}^{\mathrm{N}} \mathrm{H}^{\mathrm{Ni}}\right)$, then reduced at the nickel center. Green trace: $\mathrm{Ni}(\mathrm{PyS})_{3} \mathrm{H}^{\mathrm{N}-}$ is reduced to $\mathrm{Ni}(\mathrm{PyS})_{3} \mathrm{H}^{\mathrm{N} 2-}$, followed by proton migration to $\mathrm{Ni}(\mathrm{PyS})_{3} \mathrm{H}^{\mathrm{Ni} 2-}$. Blue trace: concerted PCET.

Figure 3-10: Spin density map for $\mathrm{Ni}(\mathrm{PyS})_{3} \mathrm{H}^{\mathrm{N}} \mathrm{H}^{\mathrm{Ni}-}$, triplet, left, and $\mathrm{Ni}(\mathrm{PyS})_{3} \mathrm{H}^{\mathrm{Ni} 2-}$, triplet, right, showing spin density located heavily on the hydride and protonated $\mathrm{PyS}^{-}$ligands respectively.

Figure 3-11: Structure of transition state between $\mathrm{Ni}(\mathrm{PyS})_{3} \mathrm{H}^{\mathrm{N}} \mathrm{H}^{\mathrm{Ni}-}$ and $\mathrm{Ni}(\mathrm{PyS})_{3}{ }^{-}+\mathrm{H}_{2}$ with bond lengths

Figure 3-12: Thermodynamic cycle for $\mathrm{H}_{2}$ production by $\mathrm{Ni}(\mathrm{PyS})_{3}{ }^{-}$. Electrochemical data reported vs SCE.

Figure 4-1: Schematic of $\mathrm{Ni}(\mathrm{PyS})_{3}{ }^{-}$compound, $\mathrm{R}$ groups are given in Table 4-1

Figure 4-2: Reaction coordinate diagram of the proposed catalytic cycle of hydrogen production by $\mathrm{Ni}\left(6-\mathrm{CH}_{3} \mathrm{PyS}\right)_{3}{ }^{-}$showing $\mathrm{CCEE}$ mechanism with proton shift from a ligand nitrogen to the Ni center (at $\mathrm{pH} 7$ ).

Figure 4-3: Reaction coordinate diagram showing prohibitively large $\Delta \mathrm{G}$ required to go from $\mathrm{Ni}\left(6-\mathrm{CH}_{3} \mathrm{PyS}\right)_{3} \mathrm{H}_{\mathrm{N}} \mathrm{H}_{\mathrm{N}}\{\mathrm{d}\}$ to $\mathrm{Ni}\left(6-\mathrm{CH}_{3} \mathrm{PyS}\right)_{3} \mathrm{H}_{\mathrm{N}} \mathrm{H}_{\mathrm{N}}{ }^{-}\{\mathrm{s}\}$ and $\mathrm{Ni}(6-$ $\left.\mathrm{CH}_{3} \mathrm{PyS}\right)_{3} \mathrm{H}_{\mathrm{N}} \mathrm{H}_{\mathrm{N}}^{-}\{\mathrm{t}\}$.

Figure 4-4: Reaction coordinate showing transition state between Ni(6$\left.\mathrm{CH}_{3} \mathrm{PyS}\right)_{3} \mathrm{~N}_{\mathrm{H}} \mathrm{N}_{\mathrm{H}}\{\mathrm{d}\}$ and $\mathrm{Ni}\left(6-\mathrm{CH}_{3} \mathrm{PyS}\right)_{3} \mathrm{~N}_{\mathrm{H}} \mathrm{Ni}_{\mathrm{H}}\{\mathrm{d}\}$. Bond lengths between $\mathrm{N}-\mathrm{H}$ and $\mathrm{Ni}-\mathrm{H}$ for the transition state are $1.66 \AA$ and $1.50 \AA$, respectively. ....71 
Figure 4-5: Reaction coordinate diagram comparing the four most likely pathways for $\mathrm{Ni}\left(6-\mathrm{CH}_{3} \mathrm{PyS}\right)_{3}{ }^{-}$catalyzed proton reduction. Thermodynamic values given for a solution of $\mathrm{pH} 7$ with no applied potential.

Figure 4-6: $\mathrm{MO}$ diagram for $\mathrm{Ni}(\mathrm{PyS})_{3} \mathrm{H}^{-}$for orbitals $100-103$ showing $\alpha$-orbitals 101 with contributions from both sulfur p-orbitals as well as nickel d-orbitals......75

Figure 4-7: $\mathrm{MO}$ diagrams from $\mathrm{Ni}(\mathrm{PyS})_{3} \mathrm{H}$ for orbitals 99,100 and 101, showing that the LUMO, 100- $\beta$, is localized at the nickel center, which would lead to a low spin configuration of $\mathrm{Ni}(\mathrm{PyS}){ }_{3} \mathrm{H}^{-}$following reduction.

Figure 4-8: A-F mapped SOMO's for derivatives demonstrating primary contribution from $\mathrm{S}$ p-orbitals. A2-F2 spin density maps for $\mathrm{Ni}(\mathrm{PyS})_{3}{ }^{-}$derivatives showing location of unpaired electron density. Atoms: white, hydrogen; grey, carbon; light blue, fluorine; dark blue, nitrogen; red, oxygen; yellow, sulfur; green, chlorine. A) $\left.\left.\mathrm{Ni}\left(3-\mathrm{CF}_{3} \mathrm{PyS}\right)_{3}{ }^{-} \mathrm{B}\right) \mathrm{Ni}\left(5-\mathrm{CF}_{3} \mathrm{PyS}\right)_{3}{ }^{-} \mathrm{C}\right) \mathrm{Ni}(6-\mathrm{S}-3-$ COOHPyS $\left.\left.\left.)_{3}{ }^{-} \mathrm{D}\right) \mathrm{Ni}(2-\mathrm{S}-3-\mathrm{COOHPyS})_{3}{ }^{-} \mathrm{E}\right) \mathrm{Ni}(5-\mathrm{ClPyS})_{3}{ }^{-} \mathrm{F}\right) \mathrm{Ni}\left(6-\mathrm{CH}_{3} \mathrm{PyS}\right)_{3}{ }^{-} .77$

Figure 4-9: Relationship between $\mathrm{E}^{0}$ from computed data and Hammett constants........78

Figure 5-1: Influence of electron donating and electron withdrawing modifications on the properties and mechanisms of homoleptic $\mathrm{Ni}(\mathrm{PyS})_{3}{ }^{-}$derivatives.

Figure 5-2: Electron rich 6- $\mathrm{CH}_{3} \mathrm{PyS}^{-}$and electron poor 3- $\mathrm{CF}_{3} \mathrm{PyS}^{-}$ligands chosen to make the heteroleptic compounds as well as the structure of the unmodified $\mathrm{Ni}(\mathrm{PyS})_{3}{ }^{-}$catalyst.

Figure 5-3: Scheme for the design of heteroleptic compounds

Figure 5-4: Naming scheme for the three isomers of $\mathrm{Ni}\left(6-\mathrm{CH}_{3} \mathrm{PyS}\right)_{2}(\mathrm{PyS})^{-}$. The naming scheme is used for all of the compounds when they are viewed with a vertical meridional plane with the sulfurs on top. The L, C and R distinctions designate the position of the one unique ligand.

Figure 5-5: Relative energies of the three isomers for each heteroleptic compound relative to the most stable isomer. $\mathrm{L}, \mathrm{C}$ and $\mathrm{R}$ indicate the position of the unique ligand for each isomer. A) $\left.\mathrm{Ni}\left(6-\mathrm{CH}_{3} \mathrm{PyS}\right)_{2}(\mathrm{PyS})^{-} \mathrm{B}\right) \mathrm{Ni}(\mathrm{PyS})_{2}(6-$ $\left.\left.\mathrm{CH}_{3} \mathrm{PyS}\right)^{-} \mathrm{C}\right) \mathrm{Ni}(\mathrm{PyS})_{2}\left(3-\mathrm{CF}_{3} \mathrm{PyS}\right)^{-}$and $\left.\mathrm{D}\right) \mathrm{Ni}\left(3-\mathrm{CF}_{3} \mathrm{PyS}\right)_{2}(\mathrm{PyS})^{-}$

Figure 5-6: A) Experimentally acquired spectra of $\mathrm{Ni}\left(6-\mathrm{CH}_{3} \mathrm{PyS}\right)_{2}(\mathrm{PyS})^{-}$(green) and $\mathrm{Ni}(\mathrm{PyS})_{2}\left(6-\mathrm{CH}_{3} \mathrm{PyS}\right)^{-}$(blue) in the UV and near UV region under both acidic and basic conditions. B) Experimentally acquired UV-vis absorbance spectra of compounds $\mathrm{Ni}(\mathrm{PyS})_{3}^{-}, \quad \mathrm{Ni}(\mathrm{PyS})_{2}\left(6-\mathrm{CH}_{3} \mathrm{PyS}\right)^{-}, \quad \mathrm{Ni}(6-$ $\left.\mathrm{CH}_{3} \mathrm{PyS}\right)_{2}(\mathrm{PyS})^{-}$and $\mathrm{Ni}\left(6-\mathrm{CH}_{3} \mathrm{PyS}\right)_{3}{ }^{-}$from left to right, showing the visible region where $\mathrm{d}$ to $\mathrm{d}$ metal transitions can be observed under neutral 
conditions C) Experimentally acquired spectra of $\mathrm{Ni}\left(3-\mathrm{CF}_{3} \mathrm{PyS}\right)_{2}(\mathrm{PyS})^{-}$ (red) and $\mathrm{Ni}(\mathrm{PyS})_{2}\left(3-\mathrm{CF}_{3} \mathrm{PyS}\right)^{-}$(blue) in the UV and near UV region. Dashed lines indicate solutions measured at $\mathrm{pH} 13$ and solid lines indicate solutions measured at $\mathrm{pH} 1.5 \mathrm{D})$ Experimentally acquired spectra of solution of a) $2: 1 \mathrm{Ni}(\mathrm{PyS})_{3}{ }^{-}$to $\mathrm{Ni}\left(3-\mathrm{CF}_{3} \mathrm{PyS}\right)_{3}{ }^{-}$at $\mathrm{pH} 13 \mathrm{~b}$ ) $2: 1 \mathrm{Ni}(\mathrm{PyS})_{3}{ }^{-}$to $\mathrm{Ni}\left(3-\mathrm{CF}_{3} \mathrm{PyS}\right)_{3}{ }^{-}$at $\left.\mathrm{pH} 1.5 \mathrm{c}\right) 2: 1 \mathrm{Ni}\left(3-\mathrm{CF}_{3} \mathrm{PyS}\right)_{3}{ }^{-}$to $\mathrm{Ni}(\mathrm{PyS})_{3}{ }^{-}$at $\left.\mathrm{pH} 13 \mathrm{~d}\right)$ 2:1 $\mathrm{Ni}\left(3-\mathrm{CF}_{3} \mathrm{PyS}\right)_{3}{ }^{-}$to $\mathrm{Ni}(\mathrm{PyS})_{3}{ }^{-}$at $\mathrm{pH} 1.5$.

Figure 5-7: $\mathrm{Ni}(\mathrm{PyS})_{2}\left(6-\mathrm{CH}_{3} \mathrm{PyS}\right)^{-}$data A) absorbance ratio of protonated and deprotonated catalyst as a function of $\mathrm{pH}$ where inflection point is used to determine $\mathrm{p} K_{a}$ B) UV-vis absorbance spectra.

Figure 5-8: A) Optimized structure of $\mathrm{Ni}(\mathrm{PyS})_{2}\left(3-\mathrm{CF}_{3} \mathrm{PyS}\right)^{-}$[L] B) $\mathrm{Ni}(\mathrm{PyS})_{2}(3-$ $\left.\mathrm{CF}_{3} \mathrm{PyS}\right)^{-}[\mathrm{C}]$ and $\left.\mathrm{C}\right) \mathrm{Ni}(\mathrm{PyS})_{2}\left(3-\mathrm{CF}_{3} \mathrm{PyS}\right)^{-}[\mathrm{R}]$ with three nitrogen protonation sites circled, with corresponding $\mathrm{p} K_{a}$ values beside them.

Figure 5-9: A) Cyclic voltammograms of $\mathrm{Ni}\left(6-\mathrm{CH}_{3} \mathrm{PyS}\right)_{2}(\mathrm{PyS})^{-}$with increasing concentration of 4-cyanoanilinium and increasing potential up to $0.1 \mathrm{M} \mathrm{4-}$ cyanoanilinium showing a change in catalytic zone B) continuation of $\mathrm{A}$ with additional acid and larger potential sweep, showing a continued change in catalytic zone C) cyclic voltammograms of $\mathrm{Ni}(\mathrm{PyS})_{2}\left(6-\mathrm{CH}_{3} \mathrm{PyS}\right)^{-}$with increasing concentration of 4-cyanoanilinium up to $0.03 \mathrm{M}$ 4cyanoanilinium D) continuation of $\mathrm{B}$ with additional acid and applied potential, showing a continued change in catalytic zone E) plot of $i_{\text {cat }} / i_{\mathrm{p}}$ for $\left.\mathrm{Ni}\left(6-\mathrm{CH}_{3} \mathrm{PyS}\right)_{2}(\mathrm{PyS})^{-}\right)$plot of $i_{\text {cat }} / i_{\mathrm{p}}$ for $\mathrm{Ni}(\mathrm{PyS})_{2}\left(6-\mathrm{CH}_{3} \mathrm{PyS}\right)^{-}$.

Figure 5-10: A) Cyclic voltammetry traces for $\mathrm{Ni}\left(3-\mathrm{CF}_{3} \mathrm{PyS}\right)_{2}(\mathrm{PyS})^{-}$with increasing additions of 4-cyanoanilinium up to $0.065 \mathrm{M}$ and B) plot of $i_{\text {cat }} / i_{p}$ vs [4cyanoanilinium]

Figure 5-11: Reaction coordinates for the three isomers of $\mathrm{Ni}\left(3-\mathrm{CF}_{3} \mathrm{PyS}\right)_{2}(\mathrm{PyS})^{-}$ highlighting numerical thermodynamic values for each protonation and reduction of $\mathrm{Ni}\left(3-\mathrm{CF}_{3} \mathrm{PyS}\right)_{2}(\mathrm{PyS})^{-}[\mathrm{C}]$. Relative energies of formation for each of the three isomers are depicted on the right, with $\mathrm{Ni}(3-$ $\left.\mathrm{CF}_{3} \mathrm{PyS}\right)_{2}(\mathrm{PyS})^{-}[\mathrm{R}]$ being the least stable and $\mathrm{Ni}\left(3-\mathrm{CF}_{3} \mathrm{PyS}\right)_{2}(\mathrm{PyS})^{-}[\mathrm{C}]$ being the most stable.

Figure 6-1: Schematic representation of electron movement through the CQD/NiNP $\mathrm{H}_{2}$ production system

Figure 6-2: TEM images of A) as synthesized NiNPs showing consistent size distribution (size distribution in S5) B) CQD showing crystal-lattice fringes C) PVP-coated NiNPs and CQDs D) reaction mixture after irradiation. 
Figure 6-3: A) uncoated CQD sample showing approximately $20 \mathrm{~nm}$ structures aggregated together B) uncoated CQD sample showing large amorphous sheets and C) PVP coated NiNPs and CQDs following irradiation with 470 $\mathrm{nm}$ light for 5 hours.

Figure 6-4: A) Emission for CQDs showing variation in emission based on excitation wavelength. B) UV-vis absorption spectra of CQDs with $0 \%, 20 \%$ and $50 \%$ PVP coating C) Emission of CQDs following excitation with 360 and 720 $\mathrm{nm}$; with and without a shortpass filter showing the disappearance of apparent upconversion with the filter in place.

Figure 6-5: A) $\mathrm{H}_{2}$ production over time for uncoated, $20 \%$ and $50 \%$ PVP-coated CQDs. B) $\mathrm{H}_{2}$ production starting again following addition of $60 \mu \mathrm{g}$ NiNPs after initial decrease in $\mathrm{H}_{2}$ production at $70 \mathrm{~min}$. Reactions run using $60 \mu \mathrm{g}$ NiNPs and $680 \mu \mathrm{g}$ CQDs in $10 \mathrm{~mL}$ of $0.5 \mathrm{M}$ EDTA in $1: 1 \mathrm{H}_{2} \mathrm{O} / \mathrm{EtOH}$, irradiated with $470 \mathrm{~nm}$ LEDs.

Figure 6-6: Effect of concentration of A) CQDs, with a constant $6 \mu \mathrm{g} / \mathrm{mL}$ of NiNPs and B) NiNPs, with a constant $68 \mu \mathrm{g} / \mathrm{mL}$ of CQD, on $\mathrm{H}_{2}$ production. $\mathrm{H}_{2}$ production amounts were measured over a period of five hours.

Figure 6-7: A) Effect of $\mathrm{pH}$ on total $\mathrm{H}_{2}$ production. Solution of $0.5 \mathrm{M}$ EDTA in 1:1 $\mathrm{H}_{2} \mathrm{O} / \mathrm{EtOH}$ used with $680 \mu \mathrm{g}$ CQD and $120 \mu \mathrm{g}$ NiNPs in a total volume of $10 \mathrm{~mL} \mathrm{~B}$ ) Effect of PVP coating by weight percent of CQDs on total $\mathrm{H}_{2}$ production after $5 \mathrm{~h}$. Solution of $0.5 \mathrm{M}$ EDTA in $1: 1 \mathrm{H}_{2} \mathrm{O} / \mathrm{EtOH}$ used with $680 \mu \mathrm{g}$ CQD and $60 \mu \mathrm{g}$ NiNP in a total volume of $10 \mathrm{~mL}$

Figure 6-8: A) $\mathrm{H}_{2}$ production over time with CQD added after 130 minutes B) $\mathrm{H}_{2}$ production over time with continued addition of NiNPs as indicated by arrows to maintain production for 150 minutes. Solution of $0.5 \mathrm{M}$ EDTA in 1:1 $\mathrm{H}_{2} \mathrm{O} / \mathrm{EtOH}$ used with $680 \mu \mathrm{g}$ CQD / $10 \mathrm{~mL}$ and $60 \mu \mathrm{g} \mathrm{NiNP} / 10 \mathrm{~mL}$ in total volume of $30 \mathrm{~mL}$. 


\section{NOMENCLATURE}

$\mathrm{Ag}^{+} / \mathrm{AgNO}_{3} \quad$ Silver/Silver nitrate reference electrode

C Chemical

CQD Carbon quantum dot

CV Cyclic voltammetry

DFT Density Functional Theory

E Electrochemical

$\mathrm{E}_{0} \quad$ Reduction potential under standard conditions (in V vs SCE)

E $\quad$ Ened $\quad$ Energy of products

$E_{\text {react }} \quad$ Energy of reactants

F Faraday's constant

$\mathrm{Fc} / \mathrm{Fc}^{+} \quad$ Ferrocene reference electrode

G Gibbs free energy

g grams

GDP Gross domestic product

$i_{\text {cat }} \quad$ Maximum current passed with excess substrate

$i_{\mathrm{p}} \quad$ Maximum current passed for activated catalyst

$\mathrm{k}_{\mathrm{obs}} \quad$ Observed rate constant

$\lambda_{\max } \quad$ Wavelength at which the maximum absorbance of a compound

occurs

L Liters

xix 


$\begin{array}{ll}\mathrm{m} & \text { mili } \\ \mu & \text { micro } \\ \mathrm{n} & \text { Number of electrons } \\ \text { NiNP } & \text { Nickel nanoparticle } \\ \mathrm{P} & \text { Pressure } \\ \mathrm{PyS} & \text { Pyridinethiolate } \\ \mathrm{PVP} & \text { Polyvinylpyrrolidone } \\ \mathrm{SCE} & \text { Saturated calomel electrode reference electrode } \\ \mathrm{T} & \text { Temperature (K) } \\ \mathrm{V} & \text { Volts }\end{array}$




\section{CHAPTER 1}

\section{INTRODUCTION}

\subsection{Global consumption and production of energy}

Developing effective, inexpensive technologies to curb current global $\mathrm{CO}_{2}$ production and preventing resulting climate change is a pressing contemporary scientific challenge. ${ }^{1-4}$ Since the advent of the industrial revolution in 1880 , atmospheric $\mathrm{CO}_{2}$ levels have been steadily on the rise, and mean global temperatures have followed. ${ }^{1,2,5-7}$ Consequences of increased global temperature include rising sea levels, disappearance of fragile ecosystems, flooding of coastal land, ocean acidification and severe weather patterns. $^{2,7-10}$ By 2050 the global population is expected to increase from 7 billion to 10 billion, with most of the increase in population occurring in developing nations. ${ }^{11,12}$ With a rise in the GDP of poorer nations, coupled with growing population, an estimated 30 terawatts of energy will be consumed annually (compared to 17 terawatts currently).,13-15 Currently $80 \%$ of the energy consumed globally is derived from fossil fuel sources such as oil, coal, peat and natural gas. ${ }^{16}$ If the bridge between current energy production and future energy needs is made through continued use of fossil fuels, climactic consequences will be significant. Using solar energy as a clean alternative to carbon based fuels is a viable solution as enough solar energy reaches the earth each hour to fuel our current energy needs for an entire year. ${ }^{3,17-20}$ 


\subsection{Conversion of solar energy using photovoltaics}

Currently, solar cells are the most widely adopted method for harnessing solar energy. Several types of solar cells exist, including crystalline silicon, organic polymer and Perovskite. These convert solar energy into electricity for immediate use. Silicon solar cells, which make up over $80 \%$ of existing solar cells, were invented in $1954 .^{21}$ Recently the market for silicon photovoltaics has grown $30-40 \%$ annually. ${ }^{20,22-24}$ Currently, the efficiency of silicon solar cells is approaching the theoretical limit of $29 \%$, with a recent 2017 report detailing a new maximum photoconversion efficiency of $26 \%$, outperforming the prior maximum efficiency of $25.6 \%$ achieved in $2012 .^{20,22,25}$ However, energy derived from fossil fuels is still less expensive than that derived from silicon solar cells. $^{20,26}$ Advances in engineering are still required in order to reduce the cost of installation to $\$ 1 /$ watt to make this energy conversion method competitive with current grid energy prices. ${ }^{27,28}$

Organic polymer solar cells are a second class of solar cell which is made of electron donor and acceptor $\pi$-conjugated small molecule polymers. ${ }^{29,30}$ The first widely employable polymers for this application were synthesized in 2001-2003, although they have been investigated since the late 1990's. ${ }^{31,32}$ Advantages of polymer solar cells are that the starting materials are inexpensive and benign and device fabrication requires mild conditions, unlike fabrication of silicon solar cells. ${ }^{33-35}$ Large-scale manufacturing is thus easier. ${ }^{29,36}$ Additionally, these devices are lightweight and flexible, making installation costs low. ${ }^{37}$ Currently, maximum efficiencies achieved for polymer solar cells are at 
slightly over $10 \%$ and $15 \%$ for tandem devices. ${ }^{38-41}$ However, polymer stability must be improved before these devices can be widely adopted and additional research is required to get more consistent outputs from device fabrication. ${ }^{29,33}$

The final type of solar cell that merits mention is Perovskite solar cells, made of mixed organic-inorganic halide perovskites. Perovskites are a family of materials whose structure is $\mathrm{ABX}_{3}$ where $\mathrm{X}$ is an anion, and $\mathrm{A}$ and $\mathrm{B}$ are cations. For photovoltaic applications, A, the larger cation, is typically methylammonium. $\mathrm{X}$ is typically iodine, although $\mathrm{Br}$ and $\mathrm{Cl}$ are also used. $\mathrm{B}$ is almost exclusively $\mathrm{Pb}$. Perovskite cells show potential due to their broad absorption of solar light and ease of fabrication. They offer a good alternative to silicon and organic polymer solar cells as they have both low manufacturing cost and high efficiency. ${ }^{42}$ The first notably efficient Perovskite solar cells were constructed in 2012, by 2013 they had a confirmed maximum efficiency of $16.2 \%$ and by 2014 the confirmed maximum efficiency had increased to $17.9 \%{ }^{43,44}$ Current maximum efficiencies have reached $22.7 \%{ }^{45}$ However, almost all of these devices contain lead, and some have shown stability issues when exposed to moisture and rain ultraviolet light. ${ }^{43,45,46}$ Finally and most importantly, all energy conversion methods such as silicon solar cells, organic polymer solar cells and Perovskite solar cells have one major flaw. They cannot produce electricity without continuous solar irradiation, and do not provide a means of energy storage. Thus, energy produced from any of these solar cells must be stored via an external process in the form of potential energy in order to be used in the absence of solar irradiation. 


\subsection{Solar energy storage}

Three currently employed large-scale solar energy storage methods include pumped hydroelectric storage, compressed air storage and batteries. Pumped hydroelectric storage is the largest commercially available means of energy storage and uses off-peak hour grid electricity to transfer water from a lower to an upper reservoir, where it is then stored in the form of gravitational potential energy. ${ }^{47,48}$ At times of higher energy demand, draining the upper reservoir creates hydroelectric energy. The efficiency of this method is $87 \%$, however geographical limitations make future facility development cost-prohibitive. ${ }^{49}$

Compressed air energy storage (CAES) uses the same method of taking off-peak hour energy and converting it to potential energy. In this case, air is pumped into subterranean caves, usually salt, hard rock or limestone, then during peak hours the air is released to generate electricity. ${ }^{48,50}$ CAES is $70 \%$ efficient but is also limited by geographical availability. ${ }^{49,51}$ Finally, deep cycle batteries are a common method of storing solar energy. Lithium ion (Li-ion), sodium sulfur ( $\mathrm{NaS})$ and nickel cadmium (NiCd) batteries have an efficiency range of $70-80 \%$, but each has its own shortcomings. ${ }^{52}$ Li-ion batteries are expensive and have short lifetimes, NaS batteries require operating temperatures of $300^{\circ} \mathrm{C}$ and $\mathrm{NiCd}$ batteries are large and have toxic

components. ${ }^{49,52}$ An alternative energy storage method that converts solar energy into clean chemical fuel is thus favored. Additionally, a transportable chemical fuel would be more easily incorporated into existing infrastructure and could be more easily distributed 
in developing nations. As such, scientists continue to research alternative solar energy storage methods, including those inspired by nature.

\subsection{Artificial photosynthesis}

Plants convert solar energy into chemical potential energy through photosynthesis, generating oxygen and sugar from sunlight, water and carbon dioxide. These sugars can be broken down to release energy at a later time, either by the plant or when they are consumed by other creatures and used as fuel. Photosynthesis occurs through step-by-step electron transfer reactions, in a process known as the Z-scheme. ${ }^{53}$ Two components are necessary, photosystems I and II. Photosystem I uses sunlight to split water into oxygen, which is released, and hydrogen. The hydrogen is combined with $\mathrm{CO}_{2}$ to produce sugars at photosystem II in a process known as carbon fixation. ${ }^{54}$ The

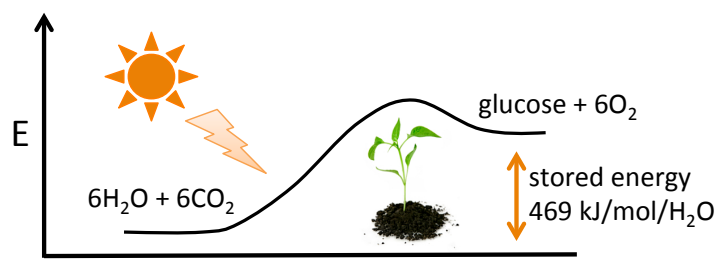

Plant photosynthesis

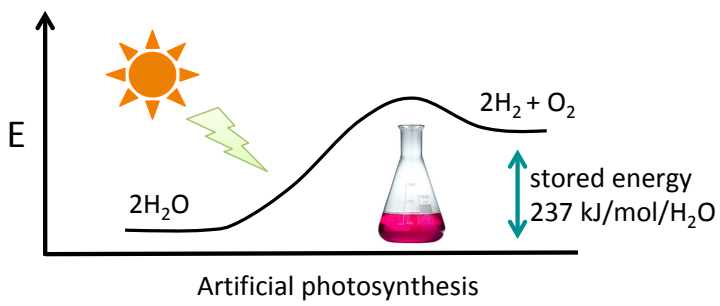

Figure 1-1: Comparative scheme of the stored energy in one molecule of glucose vs the stored energy in one molecule of hydrogen gas. 
ability of plants to use abundant materials such as sunlight, water and $\mathrm{CO}_{2}$ to produce fuel has inspired chemists to develop similar artificial photosynthesis systems in which solar energy is stored in the form of a chemical bond (Figure 1-1). Specifically, water splitting, which stores energy in the form of hydrogen gas, has attracted much attention since the 1970 's because it is a simple, environmentally friendly, two electron process. ${ }^{55}$ Additionally, hydrogen is used in many industrial syntheses of fine chemicals as well as ammonium fabrication for agriculture. ${ }^{56}$ Finding a clean method of generating hydrogen is thus of increased relevance.

Water splitting is described by the following half reactions, water oxidation (1) and proton reduction (2), and has a $\Delta \mathrm{G}=+237 \mathrm{~kJ} / \mathrm{mol} \mathrm{H}_{2} \mathrm{O}^{57}$ :

$$
\begin{aligned}
& 2 \mathrm{H}_{2} \mathrm{O} \rightarrow \mathrm{O}_{2}+4 \mathrm{H}^{+}+4 \mathrm{e}^{-} \\
& 4 \mathrm{H}^{+}+4 \mathrm{e}^{-} \rightarrow 2 \mathrm{H}_{2}
\end{aligned}
$$

There are two primary ways to perform water splitting using sunlight: electrochemically and photochemically (Figure 1-2). Electrochemical water splitting cells, which are coupled to a solar cell, use a water oxidation catalyst (or photocatalyst) at the anode to perform the first half reaction (Equation 1). Protons diffuse through an electrolyte solution while electrons are transferred through an external circuit. Electrons and protons then combine at the cathode to form hydrogen (Equation 2). ${ }^{58-60}$ The second method, photochemical water splitting, uses a water oxidation catalyst with a photosensitizer (light absorber) to perform water oxidation. Liberated electrons are transferred to a second sensitizer where another excitation process takes place and 
electron transfer to the proton reduction catalyst occurs. Once the catalyst has been protonated, these energized electrons provide the driving potential used to generate hydrogen gas. The sensitizer can be an organic dye, metal complex, semiconductor

nanoparticle or carbon based nanostructure. ${ }^{61-65}$ In order to improve the effectiveness of water oxidation and reduction, the two half-reactions are studied independently. The following discussion will explain the study of electrochemical and photochemical proton reduction systems, examined through both experimental and computational methods.

\subsection{Electrochemical water splitting}

\subsubsection{Molecular electrocatalysis using transition metal proton reduction catalysts}

Electrocatalytic hydrogen production requires the use of a proton reduction catalyst that preferably has a low overpotential and is capable of operating under neutral conditions. It is additionally desirable for the catalyst to be made of inexpensive and abundant materials. ${ }^{66-70}$ Thus, much research has gone into the development of homogenous transition-metal electrocatalysts capable of performing proton reduction under optimum conditions. Some of the most notable recent transition metal proton reduction catalysts include Ni-phosphine type compounds and various cobalt complexes. ${ }^{69,71-75}$ A great deal of effort has recently been focused on decreasing the necessary applied potential to drive the production of hydrogen. The main parameters that are used to gauge the effectiveness of proton reduction electrocatalysts include the turnover frequency $(\mathrm{TOF}=$ mols hydrogen/second), the overpotential (defined as the necessary applied potential beyond the standard potential at which hydrogen is generated) 
and the proton affinity (measured as the $\mathrm{p} K a$ ). A catalyst with a high proton affinity is capable of operating under neutral conditions, or in some cases even in basic conditions, allowing more efficient coupling to the oxygen evolving half reaction.

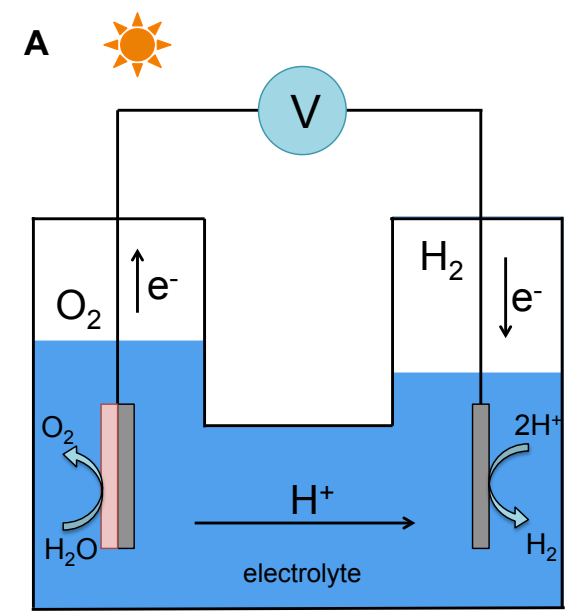

B

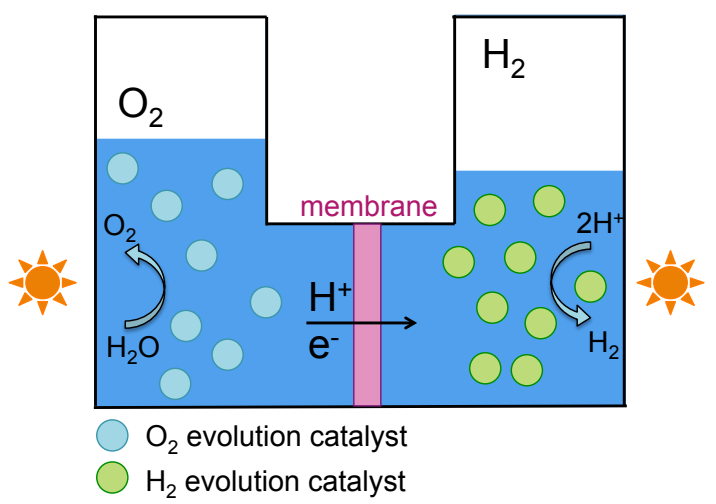

Figure 1-2: A) Electrochemical water splitting scheme B) photochemical water splitting scheme

In order to improve the effectiveness of electrochemical proton reduction catalysts, an understanding of their operative mechanism is important. ${ }^{66}$ Although proton reduction is a two-electron, two-proton process, the mechanisms by which hydrogen is produced can be surprisingly diverse and complex. Terminology used to describe the mechanisms of hydrogen production denote proton transfer steps as chemical steps (C) and electron transfer steps as electrochemical steps (E). For example, two typical hydrogen production mechanisms include a CECE mechanism and a CCEE mechanism. Additional complexity arises due to the fact that some of these steps can occur in a 
stepwise fashion while sometimes they can occur simultaneously. Distinguishing between sequential and concerted mechanisms is one of the challenges that arises in the study of electrochemical proton reduction catalysts. Extracting rate information in an appropriate manner given the operative mechanism is a complex process as well, but various methods exist to uncover mechanistic and kinetic information.

Both experimental and computational methods can be used to probe the catalytic cycles of transition-metal proton reduction catalysts. The tandem use of Density Functional Theory (DFT) along with experimental work has proven to be extremely valuable in the study of many solar energy conversion systems. ${ }^{76-78}$ Complicating issues such as those mentioned above can be dealt with through joint theoretical and experimental study. Specifically, DFT and electrochemistry provide a wealth of mechanistic information that ultimately allows for the development and improvement of new catalysts. Work by Sharon Hammes-Schiffer has provided significant insight into the computational determination of reduction potentials, $\mathrm{p} K a$ values and rates of proton and electron transfer for these types of compounds and is a good example of the level of detailed mechanistic understanding that can be gained through computational investigation. ${ }^{79-82}$ A significant volume of work also focuses on the study of protoncoupled-electron-transfer, which is of great importance in this field. ${ }^{79,81,83,84}$ Specific details explaining the methodology used to compute physical properties and determine reaction pathways is explained in the computational section of the methods chapter. 
Experimentally, two main methods are used to determine the key physical properties that dictate the effectiveness of proton reduction catalysts. The most comprehensive method is through the use of cyclic voltammetry. Work done by JeanMichel Savéant and later Jillian Dempsey provides a wealth of information about the mechanistic insight that can be gleaned through electrochemical experiments. ${ }^{85-88}$ Rates of reaction can be extracted from cyclic voltammograms and the mechanism of hydrogen production can be elucidated by studying the shapes of observed cyclic voltammetry traces. Specifically, a review by Dempsey and coworkers highlights the different catalytic zones than can be observed during electrochemical hydrogen production, and details how to interpret that information both qualitatively and quantitatively in terms of rates of product formation. ${ }^{86}$ Pure kinetic conditions, from which rate information can most easily be attained, result in $\mathrm{CV}$ traces that fall into what is called zone KS. They are easily identified by their S-shape, when the forward and reverse scans lie on top of each other. Clear examples can be seen in the work by Dempsey and coworkers. ${ }^{86}$ There is no substrate depletion in zone KS, as the concentration of substrate at the electrode matches that of the bulk solution. In this system, the substrate is the protons in solution. The most commonly encountered zone in the work undertaken here is called zone K, which is characterized by a reverse scan that does not retrace the forward scan. This shape results from depletion of substrate at the electrode surface and the rate-determining step of the reaction. Obtaining kinetic information from this zone is more challenging than zone KS, but by increasing the concentration of substrate or the scan rate, zone KS can be reached 
in some cases. More detailed explanation of the specific methods used to calculate rates of reaction can be found in the methods section.

The other informative experimental technique often employed in the study of electrochemical proton reduction catalysts is the utilization of UV-vis absorbance spectroscopy with simultaneous acid titration to determine the $\mathrm{p} K a$ values of compounds. Specifically, the ratio of the absorbance of deprotonated to protonated catalyst is plotted as a function of the $\mathrm{pH}$ of the solution. The inflection point of this curve is then taken as the $\mathrm{p} K a$ of the compound in solution. Again, specific details for both of these experimental techniques can be found in the methods chapter.

\subsubsection{Electrocatalytic proton reduction using $\mathrm{Ni}(\mathrm{PyS})_{3}{ }^{-}$}

Nickel pyridine 2-thiolate $\left(\mathrm{Ni}(\mathrm{PyS})_{3}{ }^{3}\right)$ is a proton reduction catalyst originally designed by Eisenberg and coworkers that effectively produces hydrogen both photocatalytically and electrocatalytically (Figure 1-3). It was found to be operative at high $\mathrm{pH}$ and with a relatively low overpotential. Eisenberg and coworkers previously

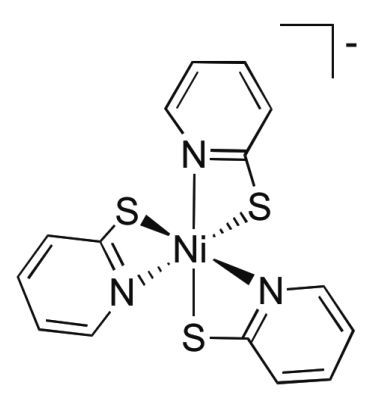

Figure 1-3: Structure of $\mathrm{Ni}(\mathrm{PyS})_{3}{ }^{-}$ 
proposed a CECE hydrogen production mechanism, where an initial protonation step occurs, followed by a reduction step, and then a proton-coupled electron transfer to yield a hydride intermediate prior to release of hydrogen gas. ${ }^{62,89}$ However, minimal experimental data existed in support of this mechanism. Chapter 1 describes the subsequent computational investigation that was undertaken herein to study the hydrogen production mechanism of this catalyst. This work ultimately supported the proposed mechanism and provided a foundation for further study of ten derivatives of $\mathrm{Ni}(\mathrm{PyS})_{3}$. Our study of $\mathrm{Ni}(\mathrm{PyS})_{3}{ }^{-}$derivatives looks at the impact of ligand modification on catalytic efficacy, quantified through observed reaction rates, as well as catalytic mechanisms. The previously mentioned experimental and theoretical methods are employed. Results of two separate studies, one on homoleptic derivatives and one on heteroleptic derivatives, are detailed in chapters II and III.

\subsection{Photochemical water splitting}

Photochemical proton reduction requires four main components: protons, electrons, a photosensitizer and a proton reduction catalyst (Figure 1-4).${ }^{90}$ In a fully integrated system, the protons and electrons would be liberated from water by the water oxidation catalyst. However, in order to study the efficiency of proton reduction, a sacrificial electron donor (SED) and a proton source are used instead. ${ }^{91}$ The SED is typically an organic molecule which gives up an electron to the photosensitizer and upon doing so does not interfere with hydrogen formation. The proton source can be the solvent itself. All components must have energy levels that are close enough to each 
other, in order for the process to occur. ${ }^{18}$ The following detailed explanation describes a fully integrated system using a semiconductor photosensitizer, although the same principles apply to the study of the proton reduction half reaction on its own as well.

As mentioned previously, water splitting is endothermic by $237 \mathrm{~kJ} / \mathrm{mol} .{ }^{57}$ This corresponds to $1.23 \mathrm{eV}$ of stored potential energy. Thus the band gap of the semiconductor photosensitizer (or the highest occupied/lowest unoccupied orbital gap in the case of molecular sensitizers) must be at least $1.23 \mathrm{~V} .^{92}$ However, in order for the reaction to be driven by visible light, the band gap must also be less than $3.0 \mathrm{~V} \cdot{ }^{93}$ Another option is to have two sensitizers with band gaps that together span the range from 1.23 and $3.00 \mathrm{~V}$ (Figure 1-4).${ }^{94}$ In addition to the magnitude of the band gap, the location of the conduction and valence bands come into play. The conduction band must be slightly

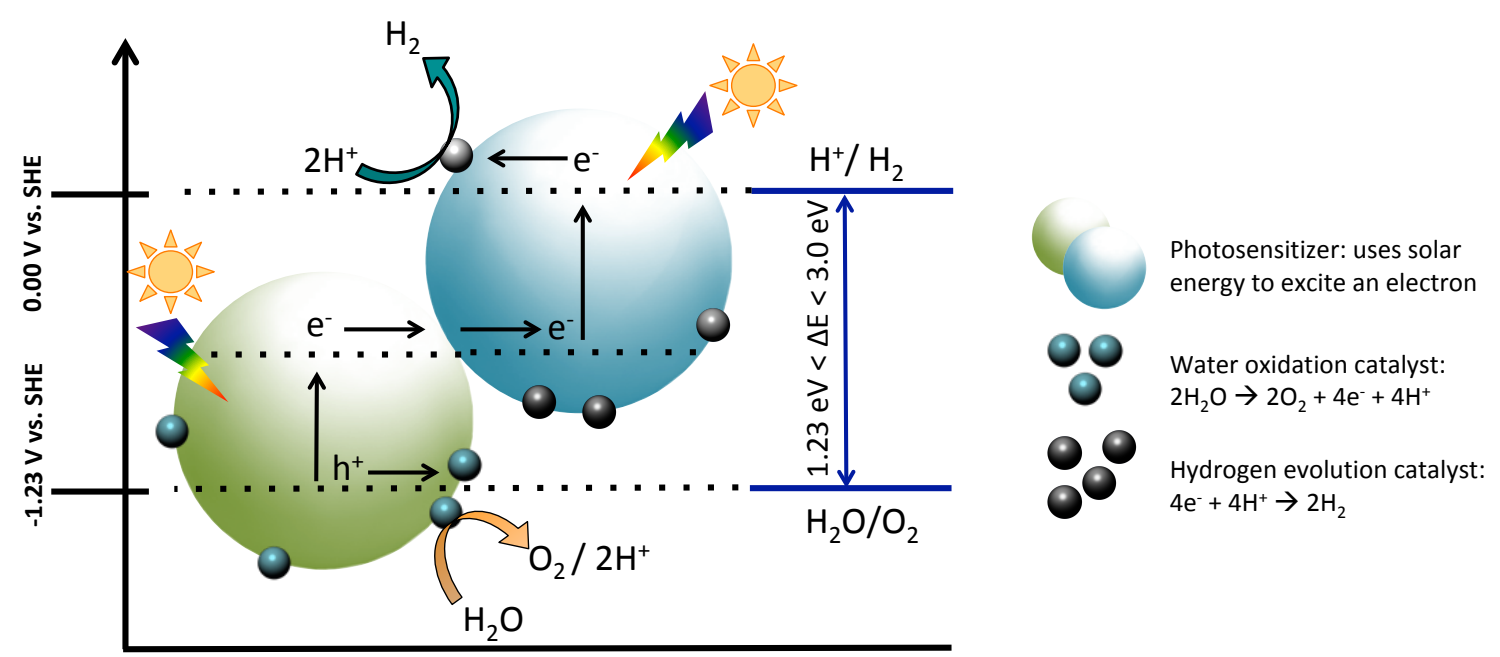

Figure 1-4: Integrated water splitting system with both water oxidation and proton reduction. Here two photosensitizers are pictured with conduction and valence bands located at the correct potentials to drive water oxidation (-1.23 V vs SHE) and proton reduction $(0.00 \mathrm{~V}$ vs SHE). 
more negative than the $\mathrm{H}^{+} / \mathrm{H}_{2}$ couple, which is at $0.00 \mathrm{~V}$ vs. the standard hydrogen electrode (SHE), and the valence band must be slightly more positive than the $\mathrm{O}_{2} / \mathrm{H}_{2} \mathrm{O}$ couple, which is at $1.23 \mathrm{~V}$ vs. SHE. ${ }^{93}$ Satisfying the necessary bandgap conditions takes care of the thermodynamic requirements to perform water splitting, but excited state lifetimes, charge separation, overpotential and other factors play an important role in determining hydrogen production as well. ${ }^{53,92,93}$

The process begins when the photosensitizer $(\mathrm{P})$ absorbs a photon to reach an excited state $\left(\mathrm{P}^{*}\right)$. From here, two mechanisms are possible; they are known as reductive quenching and oxidative quenching (Figure 1-5). ${ }^{95}$ In the reductive quenching mechanism, $\mathrm{P}^{*}$ is reduced by either electrons liberated from water, or the SED for the half reaction, to give $\mathrm{P}^{-}$. The electron is then transferred to the proton reduction catalyst. Oxidative quenching occurs when the excited electron is immediately transferred to the proton reduction catalyst, yielding $\mathrm{P}^{+}$. The photosensitizer is then reduced by either the SED of electrons from water. In both cases, the light absorber returns to the ground state. Mechanistic information can be determined experimentally through luminescence quenching experiments as well as electrochemical measurements. ${ }^{91}$ Determining whether electron transfer occurs through the reductive or oxidative mechanism gives insight into the relative rates of reaction. For example, if reductive quenching occurs, then the rate at which the hole is filled by a new electron is faster than the rate at which the excited electron transfers to the proton reduction catalyst. Luminescence, specifically fluorescence, will be looked at in more detail now. 
Molecules and structures such as quantum dots can absorb specific wavelengths of light, corresponding to the discrete energy levels of either their orbitals or conduction and valence bands. The energy that is absorbed causes an electron to be excited from the ground state to an excited state. For molecules, selection rules dictate that this transition can only occur between energy levels with the same multiplicity; e.g. singlet to singlet. Once an electron has been excited there are three possible ways in which it can return to the ground state. The first is non-radiative decay, where the energy is lost as heat. The second is non-radiative intersystem crossing, where the electron transitions to a lower energy triplet state. Lastly, radiative decay can occur; this is when the energy is emitted in the form of electromagnetic radiation (light) of a specific energy, again dictated by the discreet energy levels of the light absorber. When radiative decay occurs from states of

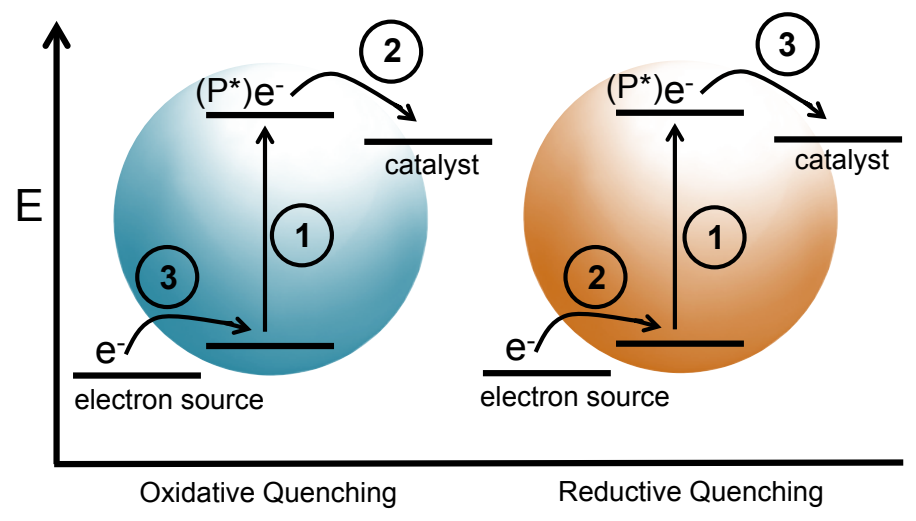

Figure 1-5: Scheme of the mechanism of oxidative quenching (left) $v s$ mechanism of reductive quenching (right) for quenching of luminescence due to electron transfer. Circled numbers indicate the order in which each step is occurring. 
the same multiplicity, the process is called fluorescence. When it occurs with a change in multiplicity it is called phosphorescence. If we think of fluorescence and phosphorescence in terms of absorption and emission of light, we note that in both cases the light that is emitted from the sample is red-shifted relative to the light that has been absorbed. For phosphorescence the shift is larger than for fluorescence, as the energy loss from intersystem crossing is greater than that of internal conversion. Internal conversion is the process by which the excited electron reaches the lowest vibrational energy state of the excited singlet state. ${ }^{96}$

When an oxidant or reductant (SED) with appropriate energy levels is combined in solution with a luminescent species, additional outcomes are possible. One such outcome is that the excited state electron can be transferred to a vacant orbital of the oxidizing species (Figure 1-5). The oxidant can be a catalyst such as a proton reduction catalyst, which then uses the high-energy electron to drive hydrogen production. Thus, luminescence quenching can be an effective tool for gauging whether or not a catalyst could be used in conjunction with a specific light absorber. Luminescence quenching is easily monitored using a fluoremeter and provides further insight including whether reductive quenching or oxidative quenching is occurring, depending on whether the reductant or the oxidant causes quenching. ${ }^{97-102}$ In the case of quantum dot sensitizers, the location of the conduction and valence bands can be determined by quenching luminescence with compounds that have known reduction and oxidation potentials. ${ }^{103}$ 
Additionally, the quenching constant may be derived using the Stern-Volmer equation (3) and can yield insight into the extent of quenching. ${ }^{88,104}$

$$
\mathrm{I}_{\mathrm{o}} / \mathrm{I}=\mathrm{K}_{\mathrm{sv}}[\mathrm{Q}]+1
$$

Equation 3 is the Stern-Volmer equation, where $I_{o}$ is the fluorescence intensity without quencher, I is the intensity of the same solution following addition of quencher, [Q] is the concentration of quencher and $\mathrm{K}_{\mathrm{sv}}$ is the fluorescence quenching constant. ${ }^{99,105}$

Finally, quantum yield $(\Phi)$ measurements can be used to characterize photosensitizers. Quantum yield is the ratio of emitted photons to absorbed photons as shown in equation 4.

$$
\Phi=\frac{\text { number of photons emitted }}{\text { number of photons absorbed }}
$$

A quantum yield of 1 means $100 \%$ of the photons absorbed undergo radiative decay back down to the ground state. Photosensitizers commonly used in water splitting applications include $\mathrm{Ru}(\mathrm{bpy})_{3}{ }^{2+}$ (bpy= bipyridine) which has a quantum yield of about 0.018-0.063, the organic dye Eosin $\mathrm{Y}$, and rhodamine dyes which have quantum yields around 0.57 and 0.9 respectively. ${ }^{106-109}$

\subsubsection{Quantum dot sensitizers for photochemical water splitting}

Study of potential photosensitizers for large-scale water splitting applications is of interest. ${ }^{110,111}$ Additionally, pairing the energy levels of newly developed sensitizers with those of proton reduction catalysts is an important step in ensuring that maximum hydrogen production efficiencies can be reached. Efficiency for hydrogen production can be measured through turnover number (TON) and hydrogen production quantum yield. 
TON measures mols $\mathrm{H}_{2} /$ mols of either catalyst or sensitizer. Hydrogen production quantum yield measures number of hydrogen molecules/ number of photons. Turnover frequency (TOF) shows the efficiency of the rate of hydrogen production measured as mols $\mathrm{H}_{2} /$ mols of either catalyst or sensitizer/ hour.

Herein, the ability of carbon quantum dots (CQDs) to act as sensitizers is studied and optimized. CQDs are carbon-based nanostructures, typically spherical, comprised of several carbon types including graphene, graphene oxide, amorphous carbon and diamond. ${ }^{65,112}$ These regions of varying carbon lattice type cause areas of aliphatic and aromatic carbon to become isolated, making them act like molecular sensitizers. Thus CQDs have a wide range of excitation and emission wavelengths, making them good candidates for use in water splitting. ${ }^{113-116}$ They have previously been used to enhance the effectiveness of semiconductor sensitizers and in one account have been used on their own to act as a light absorber for photochemical water splitting. ${ }^{65,115,117-119}$ The quantum yields of CQDs can be improved through surface modification and the optical properties can be modified. ${ }^{120}$ We take advantage of these effects to create more efficient photosensitizers.

\subsection{Outline of Thesis}

The subject of the enclosed dissertation is the study of photochemical and electrochemical energy conversion methods using both experimental and computational methods. Details of the computational and experimental work performed are given in the method section. The use of DFT to calculate reduction potentials and $\mathrm{pKa}$ values is 
explained. Electrochemical experiments used to obtain reduction potential and rates of hydrogen production are explained in detail as well as UV-vis absorption spectroscopy experiments to determine pKa values. Chapter 2 contains the initial investigation of the catalytic cycle of hydrogen production by $\mathrm{Ni}(\mathrm{PyS})_{3}{ }^{-}$using purely computational methods. This work was published in Dalton Transaction in 2015. ${ }^{121}$ Chapter 3 details the study of homoligated derivatives of $\mathrm{Ni}(\mathrm{PyS})_{3}{ }^{-}$, where each ligand is uniformly modified. The effects of symmetric ligand modification are studied by examining changes in the mechanism of hydrogen production, physical properties and effectiveness of compounds. The work on homoleptic modification of $\mathrm{Ni}(\mathrm{PyS})_{3}{ }^{-}$was published in 2018 in the Journal of Physical Chemistry A. ${ }^{207}$ Non-uniform ligand modification was studied next and is described in Chapter 4, which explains the increased complexity of heteroleptic catalyst design, synthesis and study. This work currently remains unpublished. Chapter 5 moves on to describe photocatalytic hydrogen production through the use of a dual nanomaterial system, when CQDs are used as a photosensitizer in conjunction with a NiNP catalyst. This work was published in IOP Nanotechnology in 2017. Final conclusions are in Chapter 7. 


\section{CHAPTER 2}

\section{METHODS}

\subsection{Experimental and computational methods to study electrocatalytic proton reduction}

\subsubsection{Computational determination of thermodynamic properties}

For the initial investigation of the catalytic cycle of $\mathrm{Ni}(\mathrm{PyS})_{3}{ }^{-}$, DFT calculations were performed using the Gaussian 09 suite of programs. ${ }^{122}$ Previous reports use either $\mathrm{B} 3 \mathrm{P} 6^{123-125} / 6-31+\mathrm{G}(\mathrm{d})$ or $\mathrm{B} 3 \mathrm{LYP}^{124,126} / 6-31+\mathrm{G}(\mathrm{d})$ for similar nickel based

A
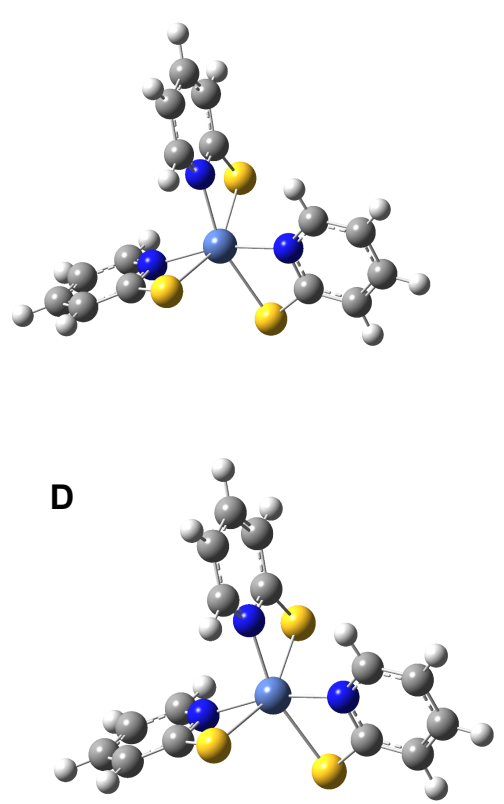

B

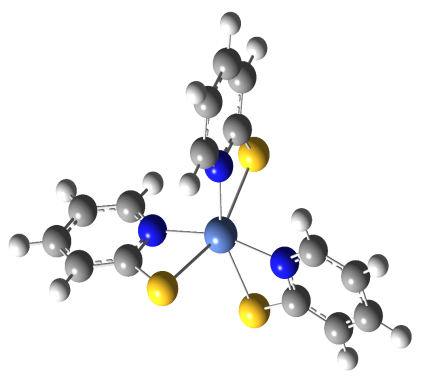

E

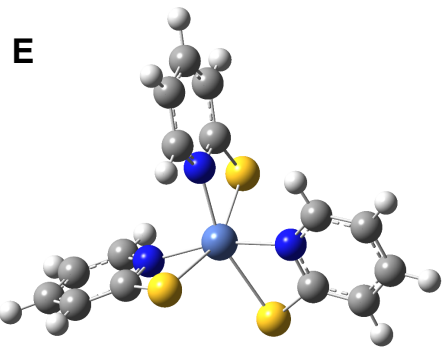

C
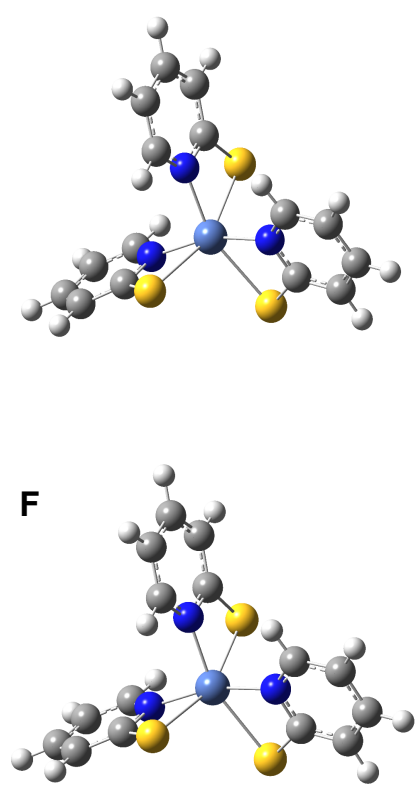

Figure 2-1: Optimized structure of $\mathrm{Ni}(\mathrm{PyS})_{3}{ }^{-}$using A) B3LYP/ gas phase B) B3LYP/ water C) B3LYP/ ethanol D) B3P86/ gas phase E) B3P86/ water F) B3P86/ ethanol. 
catalysts. $^{127,128}$ The structure of the starting catalyst $\mathrm{Ni}(\mathrm{PyS})_{3}{ }^{-}$was optimized using both levels of theory in the gas phase and using the $\mathrm{CPCM}^{129,130}$ solvation model for both ethanol and water (Figure 2-1).

It has been reported that the catalyst is active in a solvent mixture containing water and ethanol ${ }^{62}$, however since the dielectric constant of water is higher than for ethanol we used a pure water solvation model. The nickel-heteroatom bond lengths from the optimized geometries were compared to corresponding crystal structure (Table 2-1). ${ }^{131}$ Average deviation from crystal structure bond lengths obtained from B3LYP is $2.07 \%$ while the deviation obtained using B3P86 is only $0.42 \%$ (Table 2-2). Differences in bond lengths between the gas phase optimization and the optimized structure using a solvent model are negligible, however the total energy was lower using the solvent model. For these reasons, subsequent calculations were performed using B3P86/6-31+G(d) with the CPCM water solvation model.

The catalytic cycle laid out in the literature was used as a starting point for selecting intermediates of interest. ${ }^{62}$ Other isomers and alternative reaction paths were

Table 2-1: Calculated bond lengths vs crystal structure bond lengths for different basis sets and levels of theories.

\begin{tabular}{|c|c|c|c|c|c|c|c|}
\hline & $\begin{array}{l}\text { Crystal } \\
\text { Structure }\end{array}$ & $\begin{array}{c}\text { B3LYP } \\
\text { Ethanol CPCM }\end{array}$ & $\begin{array}{l}\text { B3LYP } \\
\text { gas }\end{array}$ & $\begin{array}{c}\text { B3LYP } \\
\text { Water CPCM }\end{array}$ & $\begin{array}{c}\text { B3P86 } \\
\text { Ethanol CPCM }\end{array}$ & $\begin{array}{l}\text { B3P86 } \\
\text { gas }\end{array}$ & $\begin{array}{l}\text { B3P86 } \\
\text { Water } \\
\text { CPCM }\end{array}$ \\
\hline Bond & Length & Length & Length & Length & Length & Length & Length \\
\hline $\mathrm{Ni}-\mathrm{N} 1$ & $2.034 \AA$ & $2.069 \AA$ & $2.064 \AA$ & $2.090 \AA$ & $2.063 \AA$ & $2.071 \AA$ & $2.062 \AA$ \\
\hline $\mathrm{Ni}-\mathrm{N} 2$ & $2.041 \AA$ & $2.102 \AA$ & $2.101 \AA$ & $2.065 \AA$ & $2.041 \AA$ & $2.044 \AA$ & $2.044 \AA$ \\
\hline $\mathrm{Ni}-\mathrm{N} 3$ & $2.081 \AA$ & $2.063 \AA$ & $2.071 \AA$ & $2.070 \AA$ & $2.044 \AA$ & $2.038 \AA$ & $2.041 \AA$ \\
\hline Ni-S1 & $2.541 \AA$ & $2.565 \AA$ & $2.609 \AA$ & $2.603 \AA$ & $2.549 \AA$ & $2.554 \AA$ & $2.549 \AA$ \\
\hline $\mathrm{Ni}-\mathrm{S} 2$ & $2.526 \AA$ & $2.608 \AA$ & $2.604 \AA$ & $2.596 \AA$ & $2.560 \AA$ & $2.548 \AA$ & $2.563 \AA$ \\
\hline $\mathrm{Ni}-\mathrm{S} 3$ & $2.518 \AA$ & $2.607 \AA$ & $2.564 \AA$ & $2.613 \AA$ & $2.545 \AA$ & $2.514 \AA$ & $2.545 \AA$ \\
\hline
\end{tabular}


also considered. Structures of selected intermediates were optimized with DFT to determine specific complex geometries, spin states, and total energies. Spin density maps of doublet, triplet and quartet states were generated using the cubegen utility in Gaussian 03.

The total energy of each intermediate was obtained from the total thermal and electronic energy from the frequency calculation. The $\Delta \mathrm{G}^{\circ}$ for each reaction at standard state was determined using Equation 1. $E_{\text {products }}$ and $E_{\text {reactants }}$ are the values of the total internal energy of the reaction components.

$$
\Delta \mathrm{G}_{\mathrm{rxn}}=\left[\Sigma \mathrm{E}_{\mathrm{prod}}\right]-\left[\Sigma \mathrm{E}_{\text {react }}\right]
$$

Reduction potentials were computed using isodesmic reactions with the experimental $\mathrm{Ni}(\mathrm{I})(\mathrm{PyS})_{3} \mathrm{H} / \mathrm{Ni}(\mathrm{II})(\mathrm{PyS})_{3} \mathrm{H}^{-}$couple as the theoretical reference reaction $\left(\mathrm{E}_{\text {ref }}=-1.62 \mathrm{~V}\right.$ vs SCE$)$ to generate a balanced redox reaction and calculate $\Delta \mathrm{G}_{\text {iso }}$ (Appendix Figure 1). Use of a reference reaction in this manner eliminates systematic errors resulting from electron exchange functionals and choice of basis set. ${ }^{80}$ Using the free energy change of the reaction below, the reduction potentials were determined.

Table 2-2: Calculated error for computed bond lengths.

\begin{tabular}{|c|c|c|c|c|c|c|}
\hline & $\begin{array}{c}\text { B3LYP } \\
\text { Ethanol CPCM }\end{array}$ & $\begin{array}{l}\text { B3LYP } \\
\text { gas }\end{array}$ & $\begin{array}{c}\text { B3LYP } \\
\text { Water CPCM }\end{array}$ & $\begin{array}{c}\text { B3P86 } \\
\text { Ethanol CPCM }\end{array}$ & $\begin{array}{l}\text { B3P86 } \\
\text { gas }\end{array}$ & $\begin{array}{c}\text { B3P86 } \\
\text { Water CPCM }\end{array}$ \\
\hline Bond & \%Error & $\%$ Error & \%Error & \%Error & $\%$ Error & \%Error \\
\hline Ni-N1 & 1.73 & 1.46 & 2.76 & 1.43 & 1.80 & 1.40 \\
\hline $\mathrm{Ni}-\mathrm{N} 2$ & 2.98 & 2.95 & 1.18 & 0.01 & 0.15 & 0.16 \\
\hline $\mathrm{Ni}-\mathrm{N} 3$ & -0.86 & -0.50 & -0.53 & -1.78 & -2.07 & -1.93 \\
\hline $\mathrm{Ni}-\mathrm{S} 1$ & 0.95 & 2.69 & 2.45 & 0.33 & 0.50 & 0.32 \\
\hline $\mathrm{Ni}-\mathrm{S} 2$ & 3.25 & 3.07 & 2.76 & 1.34 & 0.88 & 1.48 \\
\hline $\mathrm{Ni}-\mathrm{S} 3$ & 3.52 & 1.81 & 3.79 & 1.07 & -0.15 & 1.08 \\
\hline $\begin{array}{c}\text { Energy } \\
\text { ( Hartrees) }\end{array}$ & 3445.962706 & -3445.882271 & -3445.965484 & -3449.714625 & -3449.632615 & -3449.717432 \\
\hline
\end{tabular}




$$
\mathrm{Ox}+\mathrm{Ni}(\mathrm{I})(\mathrm{PyS})_{3} \mathrm{H}^{\mathrm{N}-} \rightarrow \operatorname{Red}+\mathrm{Ni}(\mathrm{II})(\mathrm{PyS})_{3} \mathrm{H}^{\mathrm{N}}
$$

Ox and Red are the oxidized and reduced intermediates of interest. The $\Delta G^{\circ}$ for these isodesmic reactions was used to calculate $E_{0}$ of the desired reaction using the Equation 3 where F is Faraday's constant. All reduction potentials are reported vs SCE to match experiment.

$$
\mathrm{E}_{0} \text { vs } \mathrm{SCE}=\left(-\Delta \mathrm{G}_{\text {iso }} / \mathrm{nF}\right)+\mathrm{E}_{\text {ref }}
$$

Since protonation at the ligand involves breaking the Ni-S or Ni-N bond, using an isodesmic reaction as a reference for determining the reaction $\mathrm{p} K_{a}$ becomes problematic. The reported error for $\mathrm{p} K_{a}$ calculations with B3P86 level of theory is 2.6 units if no isodesmic reaction is used to correct for systematic errors. ${ }^{132}$ To determine $\mathrm{p} K_{a}$ 's for the possible protonation sites and to calculate $\mathrm{G}$ the value of $-264 \mathrm{kcal} / \mathrm{mol}$ for water solvated $\mathrm{H}^{+}$was used. ${ }^{127}$ The $\mathrm{p} K_{a}$ was calculated using Equation 4, using $\Delta \mathrm{G}$ for the corresponding reaction below where B is the intermediate being protonated.

$$
\mathrm{B}+\mathrm{H}^{+} \rightarrow \mathrm{BH} \mathrm{p} K_{a}=-\Delta \mathrm{G} / \mathrm{RT} \ln 10
$$

Energy coordinate diagrams were generated from the free energy change of each step in the catalytic cycle with the reduction potentials referenced either to SCE or $-1.3 \mathrm{~V}$ vs SCE and a pH of 12 as indicated in the figure captions. These were chosen to indicate the reaction coordinates at experimental conditions. The reaction was optimal at $\mathrm{pH} 12$ and $-1.3 \mathrm{~V}$ is the reduction potential of reduced fluorescein dye. The $\Delta \mathrm{G}^{\circ}$ values reported in the text are at standard state, and the values in the figures are referenced to these experimental values. 
The structures of the transition states were determined using the QST2 method. Frequency calculations for the transition state structures were checked by ensuring only the presence of only one negative frequency. The normal modes for the negative frequencies were also checked to ensure that the proper transition state was being identified.

Example calculation for determination of the $p K_{a}$ of $\mathrm{Ni}(5-\mathrm{ClPyS})_{3}$

To begin, $\Delta \mathrm{G}_{\mathrm{rxn}}$ is calculated by subtracting the sum of the energies (in $\mathrm{kcal} / \mathrm{mol}$ ) of the starting catalyst and solvated proton from the energy of the protonated species:

$$
\begin{gathered}
\Delta \mathrm{G}_{\mathrm{rxn}}=\left[\Sigma \mathrm{E}_{\text {prod }}\right]-\left[\Sigma \mathrm{E}_{\text {react }}\right] \\
\Delta \mathrm{G}_{\mathrm{rxn}}=\left[\mathrm{NiE}_{3} \mathrm{NH}\right]-\left[\mathrm{NiE}_{3}^{-}+\mathrm{H}^{+}\right] \\
\Delta \mathrm{G}_{\mathrm{rxn}}=[-3028439.394]-[-3028164.751+-263.99961] \\
\Delta \mathrm{G}_{\mathrm{rxn}}=-10.64360115
\end{gathered}
$$

Next, the value of $\Delta \mathrm{G}$ is divided by $\mathrm{RT} \ln (10)$, when $\mathrm{R}$ is the gas constant and $\mathrm{T}$ is the temperature in $\mathrm{K}$, to determine $\mathrm{p} K_{a}$ :

$$
\begin{gathered}
\mathrm{pK}_{\mathrm{a}}=-\Delta \mathrm{G} /[\ln (10) \mathrm{RT}] \\
\mathrm{pK}_{\mathrm{a}}=-[-10.64360115] /[\ln (10) \mathrm{RT}] \\
\mathrm{pK}_{\mathrm{a}}=-[-10.64360115] /[1.364247] \\
\mathrm{pK}_{\mathrm{a}}=7.801813858
\end{gathered}
$$

This value can then be used to determined $\Delta \mathrm{G}$ for a reaction at given experimental conditions by first calculating an adjusted $\mathrm{p} K_{a}$. For a solution of $\mathrm{pH} 7$, the adjusted $\mathrm{p} K_{a}$ is: 


$$
\begin{gathered}
\mathrm{pK}_{\mathrm{a} \text { adj }}=\mathrm{pK}_{\mathrm{a}}-\mathrm{pH} \\
\mathrm{pK}_{\mathrm{a} \text { adj }}=7.801813858-7 \\
\mathrm{pK}_{\mathrm{a} \text { adj }}=0.801813858
\end{gathered}
$$

The adjusted $\mathrm{p} K_{a}$ value is then used to calculate a new value of $\Delta \mathrm{G}$, which accounts for the $\mathrm{pH}$ of the solution:

$$
\begin{gathered}
\mathrm{pK}_{\mathrm{a}}=-\Delta \mathrm{G} /[\ln (10) \mathrm{RT}] \\
\Delta \mathrm{G}=-\mathrm{pK}_{\mathrm{a}} * /[\ln (10) \mathrm{RT}] \\
\Delta \mathrm{G}=-0.801813858 * 1.364247 \\
\Delta \mathrm{G}=-1.09387215 \mathrm{kcal} / \mathrm{mol}
\end{gathered}
$$

Example calculation for determination of the $\mathrm{E}^{0}$ of $\mathrm{Ni}(5-\mathrm{ClPyS})_{3}$

Next, $\Delta \mathrm{G}_{\text {iso }}$ is calculated via an isodesmic reaction, by subtracting the sum of the energies of the reactants, in this case the oxidized species $\mathrm{Ni}(5-\mathrm{ClPyS})_{3} \mathrm{H}$ and the reduced reference species $\mathrm{Ni}(\mathrm{PyS})_{3} \mathrm{H}^{-}$, from the energy of the reduced species, $\mathrm{Ni}(5-\mathrm{ClPyS})_{3} \mathrm{H}$ and the oxidized reference $\mathrm{Ni}(\mathrm{PyS})_{3} \mathrm{H}$ :

$$
\begin{gathered}
\Delta \mathrm{G}_{\text {iso }}=\left[\Sigma \mathrm{E}_{\text {prod }}\right]-\left[\Sigma \mathrm{E}_{\text {react }}\right] \\
\Delta \mathrm{G}_{\text {iso }}=\left[\mathrm{NiE}_{3} \mathrm{NH}^{-}+\mathrm{Ni}(\mathrm{PyS})_{3} \mathrm{H}\right]-\left[\mathrm{NiE}_{3} \mathrm{H}+\mathrm{Ni}(\mathrm{PyS})_{3} \mathrm{H}^{-}\right] \\
\Delta \mathrm{G}_{\text {iso }}=[-3028534.654+-2173599.531]-[-3028439.394+-2173689.218] \\
\Delta \mathrm{G}_{\mathrm{rxn}}=-5.57253879
\end{gathered}
$$

This value of $\Delta \mathrm{G}$ is then used to calculate the unreferenced value of $\mathrm{E}_{0}$, using $\mathrm{F}$, Faraday's constant, and n, the number of electrons involved in the reaction:

$$
\mathrm{E}_{0 \mathrm{vac}}=\left(-\Delta \mathrm{G}_{\mathrm{iso}} / \mathrm{nF}\right)
$$




$$
\begin{gathered}
\mathrm{E}_{0 \mathrm{vac}}=(-(-5.57253879) / 23.06) \\
\mathrm{E}_{0 \mathrm{vac}}=0.241653894 \mathrm{~V} \text { vs vacuum }
\end{gathered}
$$

This value is then corrected using the reference value of $-1.18 \mathrm{~V}$ vs SCE for $\mathrm{Ni}(\mathrm{PyS})_{3} \mathrm{H}^{-} / \mathrm{Ni}(\mathrm{PyS})_{3} \mathrm{H}$ reference reaction, making the final value of $\mathrm{E}_{0}$ referenced against SCE:

$$
\begin{gathered}
\mathrm{E}_{0 \mathrm{SCE}}=\mathrm{E}_{0 \text { vac }}+\mathrm{E}_{\text {ref }} \\
\mathrm{E}_{0 \mathrm{SCE}}=0.241653894 \mathrm{~V}+-1.18 \mathrm{~V} \\
\mathrm{E}_{0 \mathrm{SCE}}=-0.938346106 \mathrm{~V} \text { vs SCE } \\
\mathrm{E}_{0 \mathrm{SCE}}=-0.94 \mathrm{~V} \text { vs SCE }
\end{gathered}
$$

\subsubsection{Experimental determination of reduction potentials and rates of hydrogen production using cyclic voltammetry}

Cyclic voltammetry measurements were performed with a Biologic SP 200 potentiostat using a one-compartment cell with a glassy carbon working electrode, a Ptwire counter electrode and a $\mathrm{Ag}^{+} / \mathrm{AgNO}_{3}$ acetonitrile reference electrode. $\mathrm{A} 10^{-3} \mathrm{M}$ solution of catalyst made in dry/degassed acetonitrile was titrated with up to 30 equivalents of a 1.0 M solution of 4-cyanoanilinium in dry/degassed acetonitrile, with $\mathrm{N}_{2}$ flowing in the headspace of the container. The potential was first swept from $0.0 \mathrm{~V}$ vs $\mathrm{Ag}^{+} / \mathrm{AgNO}_{3}$ to $-1.2 \mathrm{~V}$ vs $\mathrm{Ag}^{+} / \mathrm{AgNO}_{3}$, then back to $0 \mathrm{~V}$ vs $\mathrm{Ag}^{+} / \mathrm{AgNO}_{3}$ sweeping through $+0.5 \mathrm{~V} \mathrm{vs} \mathrm{Ag}^{+} / \mathrm{AgNO}_{3}$. Two scans were run sequentially before the next addition of acid and the electrodes were cleaned in between each run. Following an addition of acid, the solution was bubbled with $\mathrm{N}_{2}$ for two minutes before performing another scan. 
Overpotentials were determined by calculating the standard reduction potential $\left(\mathrm{E}_{\mathrm{HA} / \mathrm{H}_{2}}^{\circ}\right)$ of 4-cyanoanilinium using the equation ${ }^{86,133,134}$ :

$$
\mathrm{E}_{\mathrm{HA} / \mathrm{H}_{2}}^{\circ}=\mathrm{E}_{\mathrm{H}^{+} / \mathrm{H}_{2}}^{\circ}-\left(\frac{2.303 \mathrm{RT}}{\mathrm{F}}\right) \mathrm{pK}_{a, \mathrm{HA}, \mathrm{S}}
$$

Where $\mathrm{E}_{\mathrm{H}^{+} / \mathrm{H}_{2}}^{\circ}$ is the standard potential for the solvated proton and dihydrogen couple for a chosen solvent. The reported value of $-0.028 \mathrm{~V} \mathrm{vs} \mathrm{Fc}^{+} / \mathrm{Fc}$ in acetonitrile was used. ${ }^{135}$ The overpotential, $\eta$, is defined as the difference between $\mathrm{E}^{0}-\mathrm{E}_{\mathrm{HA} / \mathrm{H}_{2}}^{0}$. Prior to addition of acid, a reduction peak was not observed within the solvent window for any of the derivatives. Following addition of acid, a reduction peak was observed (one equivalent of acid was added to all derivatives except those containing carboxylic acid substituents, which needed four equivalents to ensure protonation of the carboxylic acid groups). Subsequent addition of acid led to a catalytic wave in all cases.

The observed rate of hydrogen production was measured by plotting the ratio of $i_{\text {cat }} / i_{\mathrm{p}}$ vs concentration of acid, until the ratio approached a plateau $\left(i_{\text {cat }}=\right.$ catalytic current and $i_{\mathrm{p}}=$ initial current). In the region where there is no longer a linear dependence on the concentration of acid, the ratio of $i_{\text {cat }} / i_{p}$ was used to calculate $k_{\text {obs }}$ (observed rate constant) and the TOF. The process is described in detail in the experimental section, using the approximate model for a pseudo-first order catalytic system. ${ }^{85,86,136-138}$ The shape of the catalytic curve indicates that pure kinetic conditions with substrate consumption are never reached. It is often challenging to reach pure kinetic conditions due to the occurrence of multiple reaction mechanisms, especially in cases where isomers exist. ${ }^{75}$ 
Extracted $k_{\text {obs }}$ are used for internal comparison between the selected catalysts in this study. This method has previously been used to estimate the rates (TOF's) of systems with complex or unknown catalytic mechanisms. ${ }^{139-145}$ Electrocatalytic TOF's determined using this method follow the same trends as the photocatalytic TOF previously determined by Eisenberg and coworkers. ${ }^{62}$

The kinetic isotope effect was observed in $\mathrm{CV}$ traces obtained using a $1 \mathrm{M} \mathrm{HCl}$ solution, made in either $10 \mathrm{~mL}$ of $\mathrm{H}_{2} \mathrm{O}$ or $\mathrm{D}_{2} \mathrm{O}$ to titrate a $10^{-3} \mathrm{M}$ solution of catalyst in a solution of $\mathrm{H}_{2} \mathrm{O}$ or $\mathrm{D}_{2} \mathrm{O}$, respectively. The experiment was performed using the same scan rate and applied potential as above.

\subsubsection{Experimental determination of $\mathrm{p} K a$ values using $U V$-vis spectroscopy}

An aqueous $1 \mathrm{M}$ solution of $\mathrm{NaOH}$ was added to a $7.5 \times 10^{-4} \mathrm{M}$ solution of catalyst in 1:1 EtOH/ $\mathrm{H}_{2} \mathrm{O}$ until the catalyst was completely deprotonated as monitored by UV-vis using a StellarNet SILVER-Nova25 BW16 Spectrometer. The sample was then titrated with $1 \mathrm{M}$ and $0.1 \mathrm{M} \mathrm{HCl}$, taking UV-Vis absorption spectra and recording $\mathrm{pH}$ between each addition, until the catalyst was completely protonated. To address the error introduced by concentration differences in each measurement, the ratio of the catalyst's absorbance at two different wavelengths was plotted against $\mathrm{pH}$. The $\mathrm{p} K_{a}$ of the catalyst was obtained by the inflection point of a fitted curve which was found by taking the second derivative of the equation of the curve and setting it equal to zero (a third or fourth degree polynomial). 


\subsubsection{Mass spectroscopy}

Mass spectroscopy was performed on a Thermo Electron LTQ-Orbitrap Discovery high-resolution mass spectrometer with electrospray ionization in negative mode.

\subsubsection{Sources of starting materials}

6-Mercaptopyridine-3-carboxylic acid, 2-Mercaptopyridine-3-carboxylic acid, 3(Trifluoromethyl)pyridine-2-thiol， 5-(Trifluoromethyl)pyridine-2-thiol，2-Mercapto-6methylpyridine, 5-chloropyridine-2-thiol, nickel (II) chloride, and sodium metal were purchased from Sigma Aldrich and used as received. Ferrocene was purchased from Acros Organics and used without purification. Lithium chloride was purchased from Fluka and used as received. Solvents were used without further purification from the MBraun Solvent system.

Chemicals used in the study of photochemical hydrogen production by CQD's and NiNP's were purchased from Sigma Aldrich or Fisher Scientific and used without further purification. $\mathrm{NiCl}_{2}(98 \% ; 1 \mathrm{~A}$ carcinogen) and citric acid (99\%) were purchased from Sigma Aldrich. PVP (molecular biology grade, $>95 \%$ ) was purchased from Fisher. The hydrogen production quantum yield was determined using a potassium ferrioxalate actinometer following published procedures. ${ }^{146}$

\subsubsection{General synthetic procedure}

All syntheses were performed using dry/degassed solvents under $\mathrm{N}_{2}$ atmosphere and complexes were stored under $\mathrm{N}_{2}$ atmosphere. Compounds $\mathrm{Ni}\left(5-\mathrm{CF}_{3} \mathrm{PyS}\right)_{3}{ }^{-}, \mathrm{Ni}(5-$ 
$\mathrm{ClPyS})_{3}{ }^{-}$, and $\mathrm{Ni}\left(6-\mathrm{CH}_{3} \mathrm{PyS}\right)_{3}{ }^{-}$were synthesized using the previously described methods. ${ }^{62}$ The remaining catalysts, $\mathrm{Ni}\left(3-\mathrm{CF}_{3} \mathrm{PyS}\right)_{3}{ }^{-}, \mathrm{Ni}(6-\mathrm{S}-3-\mathrm{COOH})_{3}{ }^{-}$, and $\mathrm{Ni}(2-\mathrm{S}-3-$ COOHPyS $)_{3}^{-}$were synthesized using a modified procedure, where a solution of deprotonated ligand was prepared using sodium methoxide in dry/degassed methanol. Following color change, indicative of deprotonation, an equivalent of $\left[\mathrm{Et}_{4} \mathrm{~N}\right] \mathrm{Br}$ was added to exchange the counter ion. Solvent was removed in vacuo and the remaining solid was dispersed into dry/degassed acetonitrile, to remove the residual salt by filtration. A solution of $\left[\mathrm{Et}_{4} \mathrm{~N}\right]_{2} \mathrm{NiCl}_{4}$ in acetonitrile was added slowly over the course of 30 minutes and allowed to react for at least two hours, until green product was formed. The catalyst then precipitated out which allowed us to remove residual salts through filtration following reduction of the solution volume by about half. Reduction potentials and rates of hydrogen production were determined as described in Chapter 2 . Electrocatalytic TOF's determined using this method (Table 4-2) follow the same trends as the photocatalytic TOF previously determined by Eisenberg and coworkers. ${ }^{62}$ $\left[\mathrm{Et}_{4} \mathrm{~N}_{2} \mathrm{NiCl}_{4}\right.$

Literature procedure ${ }^{147}$ for synthesis of the nickel precursor was followed with the exception that the stoichiometry of $\mathrm{NiCl}_{2}$ to $\left[\mathrm{Et}_{4} \mathrm{~N}\right] \mathrm{Br}$ was changed from 1:2 to 1:4. Appearance of product was as previously noted.

\subsubsection{Synthesis of derivatives of $\mathrm{Ni}(\mathrm{PyS})_{3}{ }^{-}$}

Note: the counter ion for all compounds is $\left[\mathrm{Et}_{4} \mathrm{~N}\right]^{+}$. $\mathrm{Ni}(\mathrm{PyS})_{3}\left[E t_{4} N\right]$ 
$\mathrm{Ni}(\mathrm{PyS})_{3}{ }^{-}$was synthesized as previously reported, with results as described in the literature. ${ }^{148}$ A crystal structure was obtained for $\mathrm{Ni}(\mathrm{PyS})_{3}{ }^{-}$.

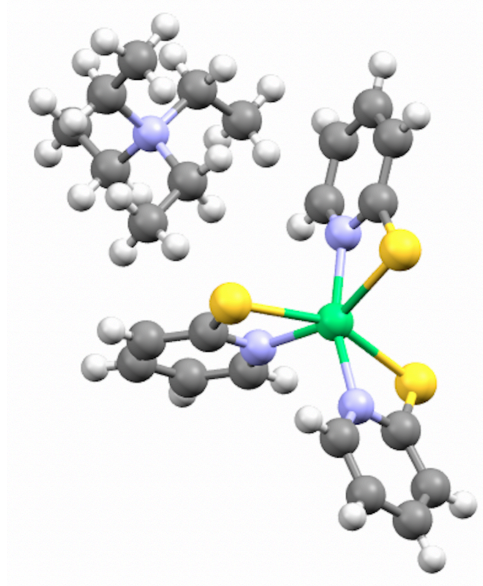

Figure 2-2: Single crystal $\mathrm{X}$-ray structure obtained for $\mathrm{Ni}(\mathrm{PyS})_{3}\left[\mathrm{Et}_{4} \mathrm{~N}\right]$. Chemical formula: $\mathrm{C}_{23} \mathrm{H}_{32} \mathrm{~N}_{4} \mathrm{NiS}_{3}$. Space group: $\mathrm{P} 2{ }_{1} / \mathrm{c}$ (14). Cell Lengths: a 14.9857(11) $\AA$ b 9.1919(3) $\AA$ c $18.7452(11) \AA$. Cell angles: a $90.039(4)^{\circ}$ b $104.865(5)^{\circ}$ g 90.067(4) ${ }^{\circ}$. Cell volume: 2495.68. Z,Z': Z: 4. R-Factor(\%): 3.91.

$\mathrm{Ni}\left(3-\mathrm{CF}_{3} \mathrm{Py}-2-\mathrm{S}\right)_{3}\left[\mathrm{Et}_{4} \mathrm{~N}\right]$

Sodium metal (.07 mmols, $1.6 \mathrm{mg})$ was dissolved into $1 \mathrm{~mL}$ of dry/degassed methanol to yield the necessary solution of sodium methoxide. Into this solution 0.26 mmols (463mg) of 3-(trifluoromethyl)pyridine-2-thiol was added and allowed to dissolve resulting in a clear yellow solution. Then 0.9 mmols $(18.9 \mathrm{mg})$ of $\left[\mathrm{Et}_{4} \mathrm{~N}\right] \mathrm{Br}$ was then added and allowed to react for one hour before solvent was removed by rotary evaporation and the remaining solid was dissolved into $0.8 \mathrm{~mL}$ of acetonitrile. Residual salt was removed through filtration before the solution was placed back under $\mathrm{N}_{2}$. A solution of 0.26 mmols $(119.86 \mathrm{mg})$ of $\left[\mathrm{Et}_{4} \mathrm{~N}\right]_{2} \mathrm{NiCl}_{4}$ in $0.8 \mathrm{~mL}$ of acetonitrile was slowly 
added via syringe over the course of 30 minutes. If the nickel precursor is added too quickly, a brown solution results instead of a green one. During the addition, if slight brown precipitate was observed, the addition could be slowed down and the reaction proceeded as intended. The final mixture was allowed to react for two hours, or until complete color change to blue/green occurred. The volume of solution was reduced by half prior to filtering to remove salt byproducts and was stored under $\mathrm{N}_{2}$ at $-10^{\circ} \mathrm{C}$. FTMS-p ESI Calcd. for $\mathrm{C}_{18} \mathrm{H}_{9} \mathrm{~N}_{3} \mathrm{~S}_{3} \mathrm{~F}_{9} \mathrm{Ni}$, 591.9168; found, 591.8486.

$\mathrm{Ni}\left(5-\mathrm{CF}_{3} \mathrm{Py2}-\mathrm{S}\right)_{3}[\mathrm{Et} 4 \mathrm{~N}]$

Sodium metal (3.4 mmols, $7.8 \mathrm{mg})$ was combined with $5 \mathrm{~mL}$ of dry/degassed methanol to make sodium methoxide. 5-(trifluoromethyl)pyridine-2-thiol (3.4 mmols, $605 \mathrm{mg}$ ) was added to this solution and yielded a clear yellow solution once dissolved, after which $3.4 \mathrm{mmol}(714 \mathrm{mg})$ of [ $\left.\mathrm{Et}_{4} \mathrm{~N}\right] \mathrm{Br}$ was added and allowed to react for one hour. Following this, solvent was removed in vacuo and the resulting solid was dissolved into $10 \mathrm{~mL}$ of dry/degassed acetonitrile. Salts were filtered out and the remaining solution was placed back under $\mathrm{N}_{2}$ before a $10 \mathrm{~mL}$ solution of $0.85 \mathrm{mmol}(392 \mathrm{mg})\left[\mathrm{Et}_{4} \mathrm{~N}\right]_{2} \mathrm{NiCl}_{4}$ in $10 \mathrm{~mL}$ of acetonitrile was slowly added over 30 minutes. Following the addition, complete color change to blue/green occurred and the volume of the solution was reduced by half before being stored at $-10^{\circ} \mathrm{C}$ under $\mathrm{N}_{2}$. FTMS $-\mathrm{p}$ ESI Calcd. for $\mathrm{C}_{18} \mathrm{H}_{9} \mathrm{~N}_{3} \mathrm{~S}_{3} \mathrm{~F}_{9} \mathrm{Ni}$, 591.9168; found, 591.8523.

$\mathrm{Ni}(3-\mathrm{COOHPy}-6-S)_{3}\left[E t_{4} N\right]$ 
Sodium methoxide was made by dissolving $2.88 \mathrm{mmols}(66 \mathrm{mg})$ of sodium into $2.2 \mathrm{~mL}$ of dry/degassed methanol. 6-mercaptopyridine-3-carboxylic acid (1.44 mmols, $222 \mathrm{mg}$ ) was then added and allowed to react over the course of an hour, ultimately yielding a clear yellow solution into which 2.88 mmols $(605 \mathrm{mg})$ of [ $\left[\mathrm{t}_{4} \mathrm{~N}\right] \mathrm{Br}$ was added. This solution was allowed to stir for an hour before the solvent was removed in vacuo and the resulting solid was dissolved into $4.3 \mathrm{~mL}$ of dry/degassed acetonitrile. Salts were removed through filtration and the solution was placed under an atmosphere of $\mathrm{N}_{2}$. A solution of 0.36 mmols $(166 \mathrm{mg})$ of $\left[\mathrm{Et}_{4} \mathrm{~N}_{2} \mathrm{NiCl}_{4}\right.$ in $4.3 \mathrm{~mL}$ of acetonitrile was made and slowly added over the course of 60 minutes. The length of time of the addition was increased to an hour to avoid solubility issues resulting from the formation of the carboxylate. Once the reaction mixture appeared blue/green, the volume was reduced by half and the solution was placed under $\mathrm{N}_{2}$ at $-10^{\circ} \mathrm{C}$ and the solid product was collected. FTMS - p ESI Calcd. for $\mathrm{C}_{18} \mathrm{H}_{10} \mathrm{~N}_{3} \mathrm{~S}_{3} \mathrm{O}_{4} \mathrm{Na}_{2} \mathrm{Ni}$, 531.8983; found, 531.9774. $\mathrm{Ni}\left(3-\mathrm{COOH}_{3} \mathrm{Py}-2-\mathrm{S}\right)_{3}\left[\mathrm{Et}_{4} \mathrm{~N}\right]$

A $2.2 \mathrm{~mL}$ solution of sodium methoxide was made by combining $2.88 \mathrm{mmols}$ (66mg) of sodium with $2.2 \mathrm{~mL}$ of dry/degassed methanol. 2-mercaptopyridine-3carboxylic acid, $1.44 \mathrm{mmols}(222 \mathrm{mg}$ ) was added and allowed to stir for an hour to ensure deprotonation, at which point 2.88 mmols $(605 \mathrm{mg})$ of [ $\left.\mathrm{Et}_{4} \mathrm{~N}\right] \mathrm{Br}$ was added and allowed to react for an hour. Solvent was then removed in vacuo and the resulting solid was dissolved into $4.3 \mathrm{~mL}$ of dry/degassed acetonitrile with residual salts removed by filtration. This solution was placed under $\mathrm{N}_{2}$ and over the course of 60 minutes a solution 
of 0.36 mmols $(166 \mathrm{mg})$ of $\left[\mathrm{Et}_{4} \mathrm{~N}\right]_{2} \mathrm{NiCl}_{4}$ in $4.3 \mathrm{~mL}$ of acetonitrile was added to yield a blue/green product. The final volume of solution was reduced to half in vacuo and stored under $\mathrm{N}_{2}$ at $-10^{\circ} \mathrm{C}$ to yield a solid product. FTMS - $\mathrm{p}$ ESI Calcd. for $\mathrm{C}_{18} \mathrm{H}_{10} \mathrm{~N}_{3} \mathrm{~S}_{3} \mathrm{O}_{4} \mathrm{Na}_{2} \mathrm{Ni}$, 531.8983; found, 531.9769.

$\mathrm{Ni}\left(5-\mathrm{Cl}_{3} P \mathrm{P}-2-\mathrm{S}\right)_{3}\left[\mathrm{Et}{ }_{4} \mathrm{~N}\right]$

Sodium methoxide was made by dissolving $1.44 \mathrm{mmols}(33 \mathrm{mg})$ of sodium into $2.2 \mathrm{~mL}$ of dry/degassed methanol and used to dissolve $1.44 \mathrm{mmols}$ (210mg) 5chloropyridine-2-thiol. Following addition of ligand the solution immediately turned clear yellow and 1.44 mmols $(302 \mathrm{mg})$ of [ $\left.\mathrm{Et}_{4} \mathrm{~N}\right] \mathrm{Br}$ was added and allowed to react for an hour. After an hour, the solvent was removed and the resulting solid was dissolved into $4.3 \mathrm{~mL}$ of dry/degassed acetonitrile. Residual salts were filtered off and the solution was placed back under $\mathrm{N}_{2}$. Into this solution a $4.3 \mathrm{~mL}$ solution of $\left[\mathrm{Et}_{4} \mathrm{~N}_{2} \mathrm{NiCl}_{4}\right.$ in acetonitrile was slowly added over the course of 30 minutes to yield a bright green solution of mixture, the volume of which was reduced by half before storing at $-10^{\circ} \mathrm{C}$ under $\mathrm{N}_{2}$ to afford the solid product. FTMS - p ESI Calcd. for $\mathrm{C}_{15} \mathrm{H}_{9} \mathrm{~N}_{3} \mathrm{~S}_{3} \mathrm{Cl}_{3} \mathrm{Ni}$, 491.8348; found 491.7782 .

$\mathrm{Ni}\left(6-\mathrm{CH}_{3} \mathrm{Py}-2-\mathrm{S}\right)_{3}\left[\mathrm{Et}{ }_{4} \mathrm{~N}\right]$

Sodium metal (3.4 mmols, 78mg) was dissolved into $5 \mathrm{~mL}$ of dry/degassed methanol to form a solution of sodium methoxide. Into this solution 3.4 mmols $(422 \mathrm{mg})$ of 6-methylpyridine-2-thiol was dissolved and combined with 3.4 mmols (714mg) of $\left[\mathrm{Et}_{4} \mathrm{~N}\right] \mathrm{Br}$ before being allowed to react for an hour. After an hour, the solvent was 
removed and the resulting solid was dissolved into $10 \mathrm{~mL}$ of dry/degassed acetonitrile. Salts were removed using filtration and the solution was placed back under $\mathrm{N}_{2}$. Over the course of 30 minutes a $10 \mathrm{~mL}$ solution of $\left[\mathrm{Et}_{4} \mathrm{~N}\right]_{2} \mathrm{NiCl}_{4}$ in acetonitrile was added to yield a light green product. The volume was reduced by half and the final solution was placed under $\mathrm{N}_{2}$ at $-10^{\circ} \mathrm{C}$. $\mathrm{Ni}\left(6-\mathrm{CH}_{3} \mathrm{Py}-2-\mathrm{S}_{3}{ }^{-}\right.$was isolated as a very light green solid. Calcd. For the ligand $\mathrm{C}_{6} \mathrm{NSH}_{6} ; 124.0221$ found 124.0092 .

$\mathrm{Ni}\left(6-\mathrm{CH}_{3} \mathrm{PyS}\right)_{2}(\mathrm{PyS})\left[\mathrm{Et}_{4} \mathrm{~N}\right]$

A $5 \mathrm{~mL}$ solution of $\mathrm{NaOCH}_{3}$ was made, by dissolving 3.4 mmols $(79 \mathrm{mg})$ of solid sodium into $5 \mathrm{~mL}$ of dry/degassed methanol. This was split into two portions of $3.33 \mathrm{~mL}$ and $1.67 \mathrm{~mL}$ to deprotonate the $\left(6-\mathrm{CH}_{3}\right) \mathrm{PySH}$ and $\mathrm{PySH}$, respectively. 2.27 mmols $(285 \mathrm{mg})$ of $\left(6-\mathrm{CH}_{3}\right) \mathrm{PySH}$ was deprotonated in the $\mathrm{NaOCH}_{3}$ and $2.27 \mathrm{mmols}$ $(580 \mathrm{mg})$ of $\left[\mathrm{Et}_{4} \mathrm{~N}\right] \mathrm{Br}$ was added. This solution was allowed to stir for one hour before removing the solvent in vacuo. The resulting solid was dispersed into $6.67 \mathrm{~mL}$ of acetonitrile and salt was filtered to yield a light yellow, transparent solution. A blue solution of $0.85 \mathrm{mmols}(390 \mathrm{mg})$ of $\left[\mathrm{Et}_{4} \mathrm{~N}_{2} \mathrm{NiCl}_{4}\right.$ in $10 \mathrm{~mL}$ of acetonitrile was then gradually added over the course of an hour. An initial color change to green occurred, followed by a final color change to a brown, opaque solution following complete addition of the nickel precursor. This solution was allowed to stir over night. A solution of PyS, $1.13 \mathrm{mmols}(125 \mathrm{mg})$, in $1.67 \mathrm{~mL}$ of $\mathrm{NaOCH}_{3}$ was then made and reacted for one hour with $1.13 \mathrm{mmols}$ of [ $\left.\mathrm{Et}_{4} \mathrm{~N}\right] \mathrm{Br}$. Solvent was removed and the resulting solid dispersed into $3.33 \mathrm{~mL}$ of acetonitrile and filtered to yield a transparent yellow solution. This ligand 
solution was added gradually to the brown, opaque reaction mixture, which gradually began to turn green. The reaction was allowed to proceed overnight and by morning the solution was a bright, opaque green. Total volume was reduced by half and residual salt was filtered. $\lambda_{\max }$ of absorbance was observed at $677 \mathrm{~nm}$. FTMS - p ESI Calculated for $\mathrm{NiC}_{17} \mathrm{H}_{15} \mathrm{~N}_{3} \mathrm{~S}_{3}$ at 414.97816 , seen at 124.00907 corresponding to $\left(6-\mathrm{CH}_{3}\right) \mathrm{PyS} \mathrm{S}^{-}$ligand and 110.90974 corresponding to PyS ${ }^{-}$ligand.

$\mathrm{Ni}(\mathrm{PyS})_{2}\left(6-\mathrm{CH}_{3} \mathrm{PyS}\right)\left[\mathrm{Et}{ }_{4} \mathrm{~N}\right]$

A $5 \mathrm{~mL}$ solution of $\mathrm{NaOCH}_{3}$ was made and separated into two portions of $3.33 \mathrm{~mL}$ and $1.67 \mathrm{~mL}$ to deprotonate $\left(6-\mathrm{CH}_{3}\right) \mathrm{PySH}$ and PySH. $252 \mathrm{mg}$ of PySH (2.27 mmols) was added into the $3.33 \mathrm{~mL}$ portion and $162 \mathrm{mg}$ of $\left(6-\mathrm{CH}_{3}\right) \mathrm{PySH}$ was added to the $1.67 \mathrm{~mL}$ portion. $240 \mathrm{mg}$ of $\left[\mathrm{Et}_{4} \mathrm{~N}\right] \mathrm{Br}$ was added to the solution of (6$\left.\mathrm{CH}_{3}\right) \mathrm{PySH}$, then solvent was removed in vacuo. The product was dissolved in acetonitrile and salt was removed though filtration. $480 \mathrm{mg}$ of $\left[\mathrm{Et}_{4} \mathrm{~N}\right] \mathrm{Br}$ was added to the PySH and allowed to react for an hour before solvent was removed in vacuo. The resulting solid was dispersed into $6.67 \mathrm{~mL}$ of acetonitrile and residual salt was filtered off. A $10 \mathrm{~mL}$ solution of $\left[\mathrm{Et}_{4} \mathrm{~N}\right]_{2} \mathrm{NiCl}_{4}$ in acetonitrile was gradually added drop-wise to this solution over the course of 30 mins, resulting in the formation of a bright green, opaque solution that gradually became full of brown/orange precipitate. An additional $4 \mathrm{~mL}$ of acetonitrile was added and the solution was allowed to stir overnight. It remained brown and opaque until the solution of $\left(6-\mathrm{CH}_{3}\right) \mathrm{PyS}^{-}$in acetonitrile was slowly added drop-wise. The previously brown solution underwent a rapid change to a bright green, opaque 
solution which was allowed to stir overnight. $\lambda_{\max }$ of absorbance was observed at $639 \mathrm{~nm}$. FTMS - p ESI Calculated for $\mathrm{NiC}_{16} \mathrm{H}_{12} \mathrm{~N}_{3} \mathrm{~S}_{3}$ at 399.95468 ; seen 401.92438, could correspond to doubly protonated species. Also see peaks at 124.0100 and 109.9900 corresponding to 6- $\mathrm{CH}_{3} \mathrm{PyS}^{-}$and $\mathrm{PyS}^{-}$ligands. Interpretation of these results is discussed in Chapter 5. $\mathrm{Ni}(\mathrm{PyS})_{2}\left(3-\mathrm{CF}_{3} \mathrm{PyS}\right)\left[\mathrm{Et} t_{4} \mathrm{~N}\right]$

A $5 \mathrm{~mL}$ solution of $\mathrm{NaOCH}_{3}$ was made and partitioned into two solutions of $1.67 \mathrm{~mL}$ and $3.33 \mathrm{~mL}$ to dissolve the $\left(3-\mathrm{CH}_{3}\right) \mathrm{PySH}(203 \mathrm{mg}, 1.13 \mathrm{mmols})$ and $\mathrm{PySH}$ (252 mg, 2.27 mmols) respectively. Once the $\mathrm{PyS}^{-}$was fully dissolved, $480 \mathrm{mg}$ (2.27 mmols) of $\left[\mathrm{Et}_{4} \mathrm{~N}\right] \mathrm{Br}$ counter ion was added and the solution was allowed to react for an hour before solvent was removed. The solid was dissolved in $6.67 \mathrm{~mL}$ of acetonitrile and the residual salt was filtered off. Into this solution, the blue, transparent, $10 \mathrm{~mL}$ solution of $\left[\mathrm{Et}_{4} \mathrm{~N}\right]_{2} \mathrm{NiCl}_{4}(390 \mathrm{mg}, 0.85 \mathrm{mmols})$ in acetonitrile was added dropwise over the course of 30 minutes. As the addition progressed, the solution became opaque and light green, eventually turning to a brown/green color. It was allowed to react overnight. The second ligand solution was made by dissolving the $\left(3-\mathrm{CH}_{3}\right) \mathrm{PySH}$ in the remaining $1.67 \mathrm{~mL}$ of $\mathrm{NaOCH}_{3}$, adding $240 \mathrm{mg}(1.13 \mathrm{mmols})$ of $\left[\mathrm{Et}_{4} \mathrm{~N}\right] \mathrm{Br}$ and allowing these to react for one hour. Solvent was removed and the product was re-dispersed in $3.33 \mathrm{~mL}$ of acetonitrile before residual salt was removed. This ligand solution was gradually added to the reaction mixture, which remained green and opaque and was allowed to react overnight again. The next day all precipitates were filtered off and the 
volume was reduced to approximately $5 \mathrm{~mL}$ which cause white precipitate to crash out, leaving behind a dark forest green solution. Salts were filtered off. FTMS - p ESI Calculated for $\mathrm{NiC}_{16} \mathrm{H}_{9} \mathrm{~N}_{3} \mathrm{~S}_{3} \mathrm{~F}_{3}$ at 453.92641 ; seen 523.87260 (expected for $\mathrm{Ni}(3$ $\left.\left.\mathrm{CF}_{3} \mathrm{PyS}\right)_{2}(\mathrm{PyS})^{-}\right)$. UV-vis absorbance recorded at $619 \mathrm{~nm}$. $\mathrm{Ni}\left(3-\mathrm{CF}_{3} \mathrm{PyS}\right)_{2}(\mathrm{PyS})\left[E t_{4} \mathrm{~N}\right]$

$\mathrm{NaOCH}_{3}, 5 \mathrm{~mL}$, was made and separated into two parts, $1.67 \mathrm{~mL}$ and $3.33 \mathrm{~mL}$, for PySH (126 mg, $1.13 \mathrm{mmols})$ and (3- $\left.\mathrm{CH}_{3}\right) \mathrm{PySH}(406 \mathrm{mg}, 2.27 \mathrm{mmols})$ respectively. Once both ligands were dissolved into the $1.67 \mathrm{~mL}$ and $3.33 \mathrm{~mL}$ aliquots of $\mathrm{NaOCH}_{3}$, $240 \mathrm{mg}$ of $\left[\mathrm{Et}_{4} \mathrm{~N}\right] \mathrm{Br}$ was added to the $\mathrm{PyS}^{-}$solution and $480 \mathrm{mg}$ of $\left[\mathrm{Et}_{4} \mathrm{~N}\right] \mathrm{Br}$ was added to the $\left(3-\mathrm{CH}_{3}\right) \mathrm{PyS}^{-}$solution. These solutions were allowed to react for an hour before solvent was removed from each in vacuo. The resulting deprotonated compound PyS[Et $4 \mathrm{~N}]$ was dissolved into $3.33 \mathrm{~mL}$ of acetonitrile and the deprotonated compound (3$\left.\mathrm{CH}_{3}\right) \mathrm{PyS}\left[\mathrm{Et}_{4} \mathrm{~N}\right]$ was dissolved into $6.67 \mathrm{~mL}$ of acetonitrile. Residual salts were filtered from both. The solution of $\left(3-\mathrm{CH}_{3}\right) \mathrm{PyS}\left[\mathrm{Et}_{4} \mathrm{~N}\right]$ was dark yellow/brown and transparent. Into this solution was added the blue, transparent acetonitrile solution of $\left[\mathrm{Et}_{4} \mathrm{~N}\right]_{2} \mathrm{NiCl}_{4}$ (390 mg, $0.85 \mathrm{mmols}$ in $10 \mathrm{~mL}$ ) yielding a green/blue solution with a slight amount of yellow precipitate. The remaining yellow ligand solution of $\left.\mathrm{PyS}_{\mathrm{E}} \mathrm{Et}_{4} \mathrm{~N}\right]$ was added slowly and yielded no apparent, immediate color change. This reaction mixture was allowed to stir overnight. After reacting overnight, the solution was still an opaque blue/green and the precipitate was filtered. The final volume was brought down to about $5 \mathrm{~mL}$ and white salt crystals precipitated out of solution. These were removed by decanting the solution. 
FTMS - p ESI Calculated for $\mathrm{NiC}_{17} \mathrm{~N}_{3} \mathrm{~S}_{3} \mathrm{H}_{10} \mathrm{~F}_{6}$ (due to $\mathrm{pH}$ of solution catalyst is protonated) at 523.92161 ; seen 523.87260 . UV-vis absorbance $\lambda_{\max }=625 \mathrm{~nm}$; broad peak.

\subsection{Experimental methods to study photocatalytic proton reduction}

\subsubsection{Experimental conditions for photochemical hydrogen production}

Gas concentrations were measured on a Hiden Analytical quadrupole mass

analyser. Emission measurements were made on a PTI Quantumax 300. ${ }^{1} \mathrm{H}$ NMR spectra were collected on a $400 \mathrm{MHz}$ Bruker Avance III spectrometer, running at $400.13 \mathrm{MHz}$ with a 9.4 Tesla magnet. The ${ }^{13} \mathrm{C}$ NMR were collected on a $600 \mathrm{MHz}$ Bruker Avance III spectrometer with a 14 Tesla magnet, operating at $150 \mathrm{MHz}$, fitted with a $5 \mathrm{~mm} \mathrm{BBO}$ probe. UV-vis spectra were taken on a StellarNet SILVER-Nova25 BW16 Spectrometer.

\subsubsection{Synthesis of CQD}

CQDs were synthesized based on the procedure used by Reisner and coworkers. ${ }^{149}$ Citric acid (100 g) was heated to $453 \mathrm{~K}$ and allowed to stir for 24 hours. After 24 hours no more stirring was possible. The white powder became a light yellow liquid and darkened until it became a hard black solid. Small samples were taken, dispersed in $\mathrm{D}_{2} \mathrm{O}$ and brought to $\mathrm{pH} 10$ using $\mathrm{NaOH}$ at 5 hours and 24 hours and analyzed with ${ }^{1} \mathrm{H}$ NMR. After 24 hours, the CQDs were allowed to cool to room temperature, subsequently half of the total solid product was dispersed in $3 \mathrm{~L}$ of water and brought to $\mathrm{pH} 10$ using $\mathrm{NaOH}$. Blue fluorescence was noted when irradiated with 
$365 \mathrm{~nm}$ light. The remaining sample was split into two batches, one was left as synthesized and to the other $29 \mathrm{~K} \mathrm{MW}$ polyvinylpyrrolidone (PVP) was added at the following percentages by weight of the CQDs: 5\% (0.5 g PVP), 10\% (1.0 g PVP), 20\% (2.0 g PVP), 35\% (3.5 g PVP), 50\% (5.0 g PVP). ${ }^{1} \mathrm{H}$ NMR $\left(\mathrm{CDCl}_{3}, 20^{\circ} \mathrm{C}\right): \delta \mathrm{ppm} 8.40$, $7.75,7.25,5.45,3.5,2.0-2.5,0.75-1.75 .{ }^{1} \mathrm{C}$ NMR $\left(\mathrm{H}_{2} \mathrm{O}\right): \delta \mathrm{ppm} 180-185,120-145,10-42$.

\subsubsection{Synthesis of NiNPs ${ }^{150,151}$}

$\mathrm{Ni}(\text { acac })_{2}(520 \mathrm{mg}, 2 \mathrm{mmol})$ was mixed into oleylamine $(2 \mathrm{~mL})$ in a $100 \mathrm{~mL}$ oneneck round-bottom flask, filled with an Ar atmosphere. The resulting blue slurry was stirred for 20 minutes at $100^{\circ} \mathrm{C}$. Trioctylphosphine (TOP, $5 \mathrm{~mL}$ ) was injected into the slurry, resulting in a translucent blue solution after 2 minutes of stirring. The temperature was increased to $200^{\circ} \mathrm{C}$, and the solution turned from blue to deep black. The solution was kept at $200^{\circ} \mathrm{C}$ for 30 minutes, then cooled to room temperature in a water bath. The solution was transferred to a centrifuge tube, in which the nanoparticles were flocculated by the addition of $35 \mathrm{~mL}$ ethanol and centrifuged for 15 minutes at $3.0 \mathrm{rcf}$. The ethanol was decanted off, and the particles were washed 3 times in $40 \mathrm{~mL}$-hexane/ethanol (1:3), centrifuging each wash for 30 minutes at $3.0 \mathrm{rcf}$.

NiNPs $(100 \mathrm{mg})$ were then dispersed in $10 \mathrm{~mL}$ of n-hexane in a $100 \mathrm{~mL}$ one-neck round-bottom flask. PVP $29 \mathrm{~K}(700 \mathrm{mg})$ was dissolved in $6 \mathrm{~mL}$ of chloroform and added to the flask. The flask was stoppered, placed under an Ar atmosphere, then stirred and heated at $65^{\circ} \mathrm{C}$ for 12 hours. After cooling to room temperature, the solution was transferred to a centrifuge tube in which the nanoparticles were flocculated with $20 \mathrm{~mL}$ 
ethanol and centrifuged for $20 \mathrm{~min}$ at $3.0 \mathrm{rcf}$. The solvents were decanted off, and the particles were washed 3 times with acetone/ethanol (1:1), centrifuging each wash for 30 minutes at 3.0 rcf. $^{151}$

\subsubsection{Transmission Electron Microscopy and EDX}

Transmission Electron Microscopy (TEM) and Energy Dispersive X-ray Spectroscopy (EDX) were performed on a FEI Technai F-20 operating at $200 \mathrm{kV}$ and equipped with an Oxford Instruments EDX detector. The sample grids used were Lacey Carbon Film over 400 mesh copper purchased from Ted Pella. Samples were prepared by sonicating a moderately dilute sample $(10 \mathrm{mg} / 1 \mathrm{~mL})$ for 10 seconds, then drop casting onto the grid. The samples were left to dry in air for 3 hours prior to imaging. No heat was applied.

\subsubsection{Fluorescence Quantum Yield Measurements}

Quantum yield measurements were performed using a petite integrating sphere attachment. The excitation and emission spectra were corrected using the Emcorr_Quanta_Solid/Sphere correction with the Felix software. A 2.0 optical density neutral density filter was used while measuring the excitation light. Each sample contained $1.4 \mathrm{mg}$ of CQD diluted to a total volume of $10 \mathrm{~mL}$ in $1: 1 \mathrm{water} / \mathrm{EtOH}$. The quantum yield of the $0 \%, 5 \%, 10 \%, 20 \%, 35 \%$ and $50 \%$ PVP-coated particles were measured at various excitation wavelengths. 


\subsubsection{Fluorescence quenching studies}

A solution of $4 \mathrm{mg} C Q D$ in $10 \mathrm{~mL}$ of $1: 1 \mathrm{H}_{2} \mathrm{O} / \mathrm{EtOH}$ was titrated with a variety of sacrificial electron donor solutions (triethylamine, ascorbic acid, triethanolamine and EDTA) as well as NiNP solution. After each addition of quencher, the emission intensity of the CQDs was measured.

\subsubsection{Hydrogen production}

Hydrogen production was carried out in sealed $50 \mathrm{~mL}$ vials equipped with septa and $10 \mathrm{~mL}$ of solution. Each vial was purged five times and reactions were run under $\mathrm{N}_{2}$ at atmospheric pressure in an ice bath. The $\mathrm{N}_{2}$ was used as an internal standard for the hydrogen production measurement. The gas composition of the headspace was measured with the mass analyzer. All measurements were repeated three times at a minimum. Reaction rates were determined by continuous monitoring of $\mathrm{N}_{2}$ gas bubbled through the reaction mixture. An oil bubbler outlet was used to ensure the reaction remained at a constant internal pressure. The samples were irradiated with $470 \mathrm{~nm}$ light from LEDs. Specific reagents used and their corresponding concentrations are reported in Chapter 6. 
CHAPTER 3

INITIAL COMPUTATIONAL INVESTIGTION OF NICKEL PYRIDINETHIOLATE DFT Analysis into the Intermediates of Nickel Pyridinethiolate Catalyzed Proton

\section{Reductions}

This work is published in Dalton Transactions.

Virca, C. N.; Mccormick, T. M. DFT Analysis into the Intermediates of Nickel Pyridine Thiolate Catalyzed Proton Reduction: Supporting Information. Dalt. Trans. 2015, 1-28.

\subsection{Introduction}

Finding an efficient way to generate clean, low-cost energy is fundamental for environmental preservation and the improvement of living conditions for people in developing nations. ${ }^{3,13}$ Converting water to hydrogen as a clean fuel source using precious-metal free water reduction catalysts is of great interest. ${ }^{63,152,153}$ Both cobalt and nickel catalysts have been shown to be effective for water reduction. ${ }^{62,64,89,102,143,154-160}$ Specifically, the $\mathrm{Ni}(\mathrm{PyS})_{3}{ }^{-}$catalyst has shown high activity and stability in photochemical systems. $^{62,89}$

The reaction pathway for this catalyst has been proposed from experimental observations (Figure 3-1). ${ }^{62}$ In the proposed reaction pathway, $\mathrm{Ni}(\mathrm{PyS})_{3}{ }^{-}$undergoes protonation at a pyridyl nitrogen to form $\mathrm{Ni}(\mathrm{PyS})_{3} \mathrm{H}^{\mathrm{N}}$, followed by reduction $\left(\mathrm{Ni}(\mathrm{PyS})_{3} \mathrm{H}^{\mathrm{N}-}\right)$ then proton coupled electron transfer to make the hydride, $\mathrm{Ni}(\mathrm{PyS})_{3} \mathrm{H}^{\mathrm{N}} \mathrm{H}^{\mathrm{Ni}}$, 
and finally release of hydrogen. In this study we examine electronic and structural properties of the reaction intermediates using DFT calculations.

A recent review highlighted several advancements towards using computations in rational design of water-reduction catalysts. ${ }^{161}$ Computational methods have previously been used to enhance knowledge of hydrogen evolution catalytic cycles in a similar manner, ${ }^{77,82,127,128,158,159,162-164}$ including those of cobalt glyoxime $e^{80,165,166}$ and $\mathrm{Ni}$ P2N2 $2^{141,167-169}$ type catalysts. The objective of the work in this chapter is to use DFT methods to probe the intermediates in the proton reduction pathway of $\mathrm{Ni}(\mathrm{PyS})_{3}{ }^{-}$. DFT can provide information on reaction intermediates that are difficult to probe experimentally, eg. spin state, localization of charges and structure. Also identification of high-energy intermediates could help target catalyst modification to increase catalytic

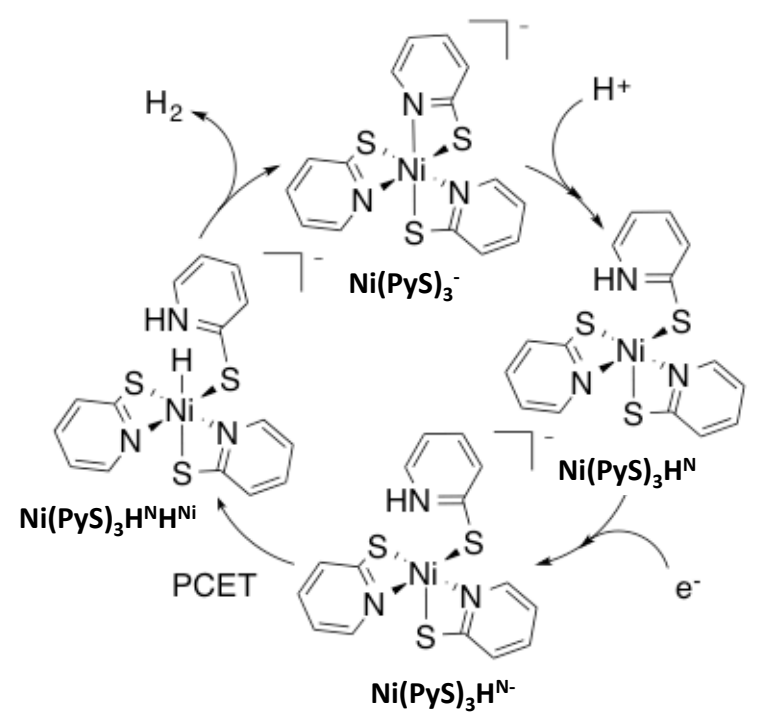

Figure 3-1: Proposed catalytic cycle for proton reduction by $\left[\mathrm{Ni}(\mathrm{PyS})_{3}\right]^{-}$with cation omitted. 
turnover frequency.

To this end, we have determined the energies of key intermediates through frequency calculations, identified a potential transition state and generated spin density maps for intermediates in various spin states. Geometries were determined through optimization calculations performed on possible intermediates of the reaction pathway. Optimized structures allowed us to explore the possibility of solvent coordination at a vacant site on the nickel during the catalytic cycle.

\subsection{Results and Discussions}

\subsubsection{Protonation}

Experimental results indicate protonation occurs prior to reduction; a reduction wave is only observed after addition of acid to the catalyst. ${ }^{89}$ We calculated the reduction potential of $\mathrm{Ni}(\mathrm{PyS})_{3}{ }^{-}$to be $-1.9 \mathrm{~V}$. This potential is too negative to be reduced under experimental conditions, corroborating that protonation must occur first.

Protonation can occur at either the sulfur or pyridyl nitrogen; resulting in dechelation of the ligand. Protonation of the pyridyl nitrogen is proposed by Eisenberg et al. A crystal structure of a similar compound, $\mathrm{Ni}(\mathrm{H}-\mathrm{PyS})_{4},{ }^{62}$ shows protonation of the pyridyl nitrogen in a square planar compound with only remaining sulphur coordination. However, for a similar complex with a tris-phosphine chelating ligand and a PyS ${ }^{-}$ligand, it has been suggested that protonation occurs at the sulphur without detachment from the nickel, followed by proton migration to the detached pyridyl nitrogen. ${ }^{170}$ To probe the preferred protonation site we optimized structures with one protonated sulfur, both 
attached (ring closed) $\mathrm{Ni}(\mathrm{PyS})_{3} \mathrm{H}^{\mathrm{S}}{ }_{\text {closed }}$ and detached (ring open) $\mathrm{Ni}(\mathrm{PyS})_{3} \mathrm{H}^{\mathrm{S}}$ open from the nickel, and the protonated pyridyl nitrogen (ring open), $\mathrm{Ni}(\mathrm{PyS})_{3} \mathrm{H}^{\mathrm{N}}$. The open and closed structures of the protonated sulfur optimize to the same open structure, $\mathrm{Ni}(\mathrm{PyS})_{3} \mathrm{H}^{\mathrm{S}}$ (Figure 3-2). Dechelation of the protonated ligand results in a square pyramidal structure. The meridional geometry of $\mathrm{Ni}(\mathrm{PyS})_{3}{ }^{-}$results in two distinct pyridyl nitrogen sites. Protonation to form the cis isomer is statistically more likely, and slightly lower in energy; as such we only consider the cis geometry.

Using the energy of a solvated proton, the $\mathrm{p} K_{a}$ for the species protonated at the sulfur and nitrogen were calculated to be 3.2 and 9.9 respectively (Equation 5 and 6 in standard state). The experimentally determined $\mathrm{p} K_{a}$ of the catalyst is $12.1 .^{89}$ The

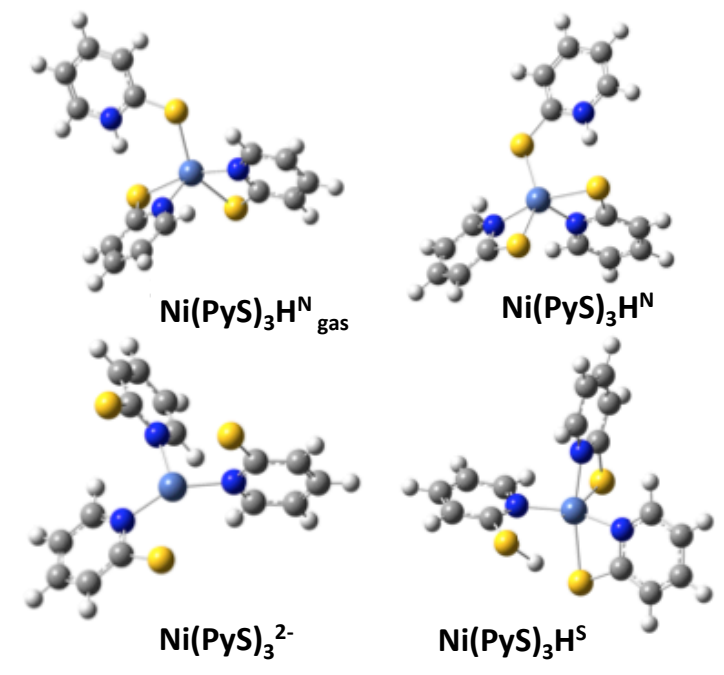

Figure 3-2: Optimized structures of $\mathrm{Ni}(\mathrm{PyS})_{3} \mathrm{H}^{\mathrm{N}}{ }_{(\mathrm{gas})}, \mathrm{Ni}(\mathrm{PyS})_{3} \mathrm{H}^{\mathrm{N}}, \quad \mathrm{Ni}(\mathrm{PyS})_{3} \mathrm{H}^{\mathrm{S}}$ and $\mathrm{Ni}(\mathrm{PyS})_{3}{ }^{2-}$. Grey, carbon; Blue, nitrogen; Yellow, sulfur; White, hydrogen; Light Blue, nickel. 
calculated $\mathrm{p} K_{a}$ of 9.9 for the species protonated at the pyridyl nitrogen is within the 2.6 unit error typical for this method. ${ }^{127}$ The photocatalytic experimental reaction conditions report an optimal $\mathrm{pH}$ of 12 . Protonation at the sulfur under these conditions is less favored than protonation at the nitrogen and unlikely to occur (Figure 3-3).

$$
\begin{array}{ll}
\mathrm{Ni}(\mathrm{PyS})_{3}{ }^{-}+\mathrm{H}^{+} \rightarrow \mathrm{Ni}(\mathrm{PyS})_{3} \mathrm{H}^{\mathrm{S}} & \Delta \mathrm{G}^{\circ}=-4.31 \mathrm{kcal} / \mathrm{mol} \text {, pKa } 3.2 \\
\mathrm{Ni}(\mathrm{PyS})_{3} \mathrm{H}^{-}+\mathrm{H}^{+} \rightarrow \mathrm{Ni}(\mathrm{PyS})_{3} \mathrm{H}^{\mathrm{N}} & \Delta \mathrm{G}^{\circ}=-13.5 \mathrm{kcal} / \mathrm{mol}, \mathrm{pKa} 9.9
\end{array}
$$

The calculated $\mathrm{p} K_{a}$ for the species protonated at the pyridyl nitrogen supports that the catalytic cycle starts with protonation and subsequent reduction to form complex $\mathrm{Ni}(\mathrm{PyS})_{3} \mathrm{H}^{\mathrm{N}-}$.

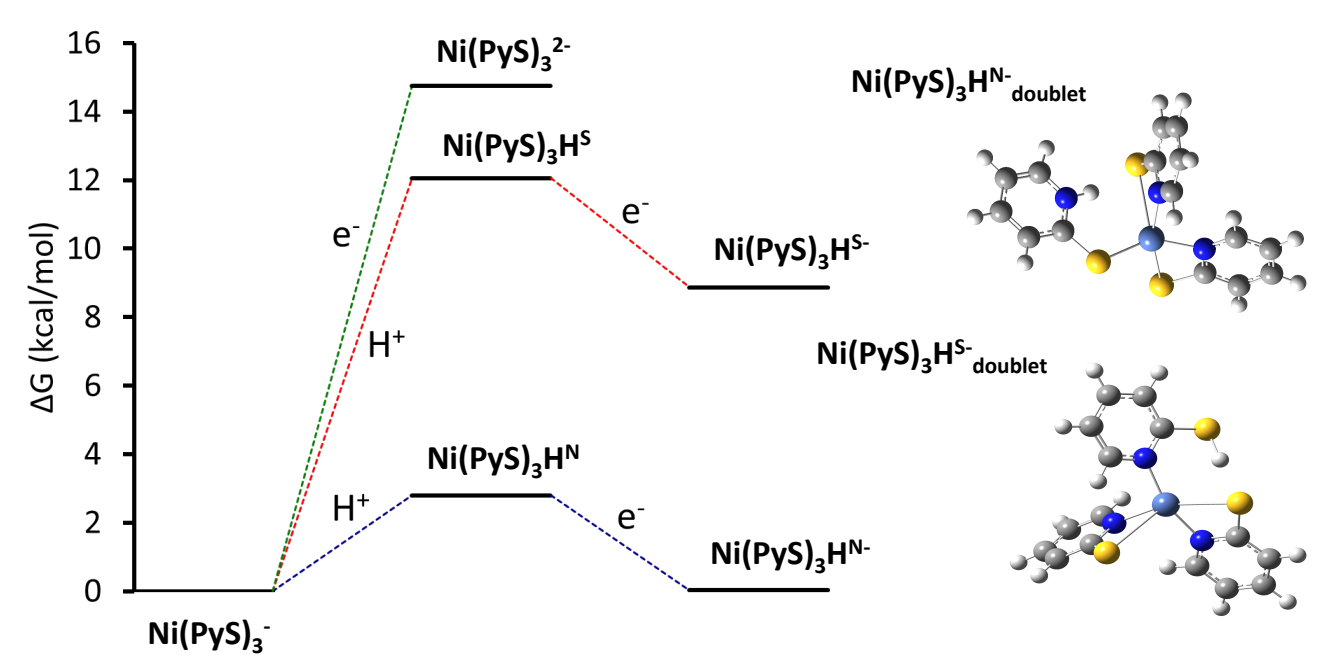

Figure 3-3: Energy coordinate diagram at $\mathrm{pH} 12$ of: Green: reduction of $\mathrm{Ni}(\mathrm{PyS})_{3}{ }^{-}$; Red: protonation at sulfur followed by reduction; Blue: protonation at pyridyl nitrogen followed by reduction. Optimized structures of both $\mathrm{Ni}(\mathrm{PyS})_{3} \mathrm{H}^{\mathrm{N}-}$ and $\mathrm{Ni}(\mathrm{PyS})_{3} \mathrm{H}^{\mathrm{S}-}$ with doublet spin states. 


\subsubsection{Geometry and Water Coordination}

The catalyst, $\mathrm{Ni}(\mathrm{PyS})_{3}{ }^{-}$is in an octahedral configuration. Initial protonation at a pyridyl nitrogen detaches the nitrogen at which point the complex is five-coordinate square-pyramidal leaving a vacant coordination site that could be occupied by solvent. The reaction solvent is a mixture of water and ethanol. Due to electrostatic potential and size of water we considered water coordination. To explore water coordination, we optimized the geometry and performed frequency calculations on the intermediates both with $\left(\mathrm{Ni}(\mathrm{PyS})_{3} \mathrm{H}^{\mathrm{N}} \cdot \mathrm{H}_{2} \mathrm{O}\right)$ and without $\left(\mathrm{Ni}(\mathrm{PyS})_{3} \mathrm{H}^{\mathrm{N}}\right)$ a coordinated explicit water molecule (Figure 3-4). Compound $\mathrm{Ni}(\mathrm{PyS})_{3} \mathrm{H}^{\mathrm{N}} \cdot \mathrm{H}_{2} \mathrm{O}$ has a similar geometry as $\mathrm{Ni}(\mathrm{PyS})_{3} \mathrm{H}^{\mathrm{N}}$, but with a water molecule occupying the vacant coordination site.

Coordination of water to the vacant site is not energetically favorable for the protonated compound $\mathrm{Ni}(\mathrm{PyS})_{3} \mathrm{H}^{\mathrm{N}}$ by $6.42 \mathrm{kcal} / \mathrm{mol}$ (Equation 7). The standard state is calculated with $1 \mathrm{M} \mathrm{H}_{2} \mathrm{O}$; considering water as a solvent $(55 \mathrm{M})$ this reaction is also not
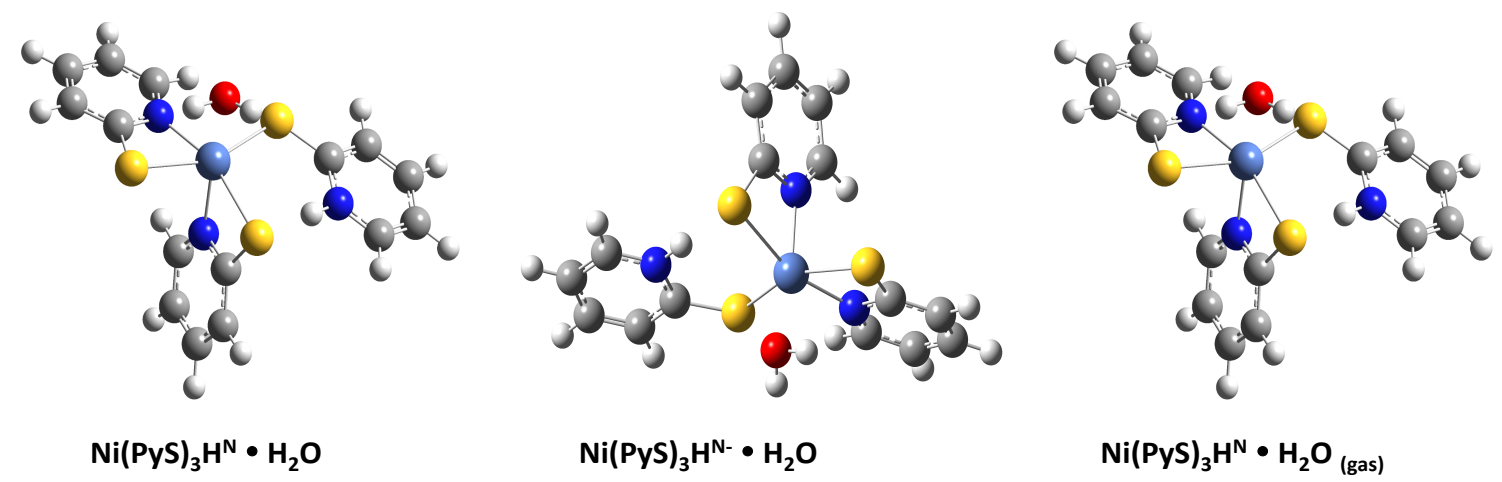

Figure 3-4: Structure $\mathrm{Ni}(\mathrm{PyS})_{3} \mathrm{H}^{\mathrm{N}} \cdot \mathrm{H}_{2} \mathrm{O}$ optimized in water and in the gas phase and structure $\mathrm{Ni}(\mathrm{PyS})_{3} \mathrm{H}^{\mathrm{N}-} \bullet \mathrm{H}_{2} \mathrm{O}$ optimized using water with a CPCM solvation model. 
spontaneous. Furthermore, the reduction potential of $\mathrm{Ni}(\mathrm{PyS})_{3} \mathrm{H}^{\mathrm{N}} \bullet \mathrm{H}_{2} \mathrm{O}$ is $-2.4 \mathrm{~V}$, far from the experimentally observed value of $-1.18 \mathrm{~V}$.

$$
\begin{array}{ll}
\mathrm{Ni}(\mathrm{PyS})_{3} \mathrm{H}^{\mathrm{N}}+\mathrm{H}_{2} \mathrm{O} \rightarrow \mathrm{Ni}(\mathrm{PyS})_{3} \mathrm{H}^{\mathrm{N}} \bullet \mathrm{H}_{2} \mathrm{O} & \Delta \mathrm{G}^{\circ}=+6.42 \mathrm{kcal} / \mathrm{mol} \\
\mathrm{Ni}(\mathrm{PyS})_{3} \mathrm{H}^{\mathrm{N}-}+\mathrm{H}_{2} \mathrm{O} \rightarrow \mathrm{Ni}(\mathrm{PyS})_{3} \mathrm{H}^{\mathrm{N}-} \bullet \mathrm{H}_{2} \mathrm{O} & \Delta \mathrm{G}^{\circ}=+34.96 \mathrm{kcal} / \mathrm{mol}
\end{array}
$$

After reduction the catalyst is still five coordinate. Likewise, water coordination after reduction is thermodynamically unfavorable with $\Delta \mathrm{G}=+34.96 \mathrm{kcal} / \mathrm{mol}$ (Equation 8). Calculations indicate that although there is a vacant coordination site on complex $\mathrm{Ni}(\mathrm{PyS})_{3} \mathrm{H}^{\mathrm{N}}$ and $\mathrm{Ni}(\mathrm{PyS})_{3} \mathrm{H}^{\mathrm{N}-}$, water coordination to make $\mathrm{Ni}(\mathrm{PyS})_{3} \mathrm{H}^{\mathrm{N}} \cdot \mathrm{H}_{2} \mathrm{O}$ and $\mathrm{Ni}(\mathrm{PyS})_{3} \mathrm{H}^{\mathrm{N}-} \bullet \mathrm{H}_{2} \mathrm{O}$ is not energetically favorable and is unlikely to occur.

However, coordination of a hydroxide to $\mathrm{Ni}(\mathrm{PyS})_{3} \mathrm{H}^{\mathrm{N}}$ to get $\mathrm{Ni}(\mathrm{PyS})_{3} \mathrm{H}^{\mathrm{N}} \cdot \mathrm{OH}^{-}$ ion is exothermic, $\Delta \mathrm{G}^{\circ}=-11.38 \mathrm{kcal} / \mathrm{mol}$. The reduction potential of $\mathrm{Ni}(\mathrm{PyS})_{3} \mathrm{H}^{\mathrm{N}} \cdot \mathrm{OH}^{-}$ is $-1.7 \mathrm{~V}$, outside the potential available under experimental conditions indicating that either reduction of $\mathrm{Ni}(\mathrm{PyS})_{3} \mathrm{H}^{\mathrm{N}}$ is kinetically favored over hydroxide coordination or hydroxide coordination is reversible. This intermediate is unlikely to contribute to the catalytic cycle and is not considered further.

\subsubsection{Spin State}

The spin state of the complex is set by the user in the calculation setup, allowing both investigation into various spin states and room for error in choosing the incorrect spin state. For most organic molecules all electrons are paired and a singlet spin state can be assumed, however transition metal complexes are more complicated. ${ }^{171,172} \mathrm{Six}$ coordinate $\mathrm{Ni}(\mathrm{II})$ is octahedral $\mathrm{d}^{8}$ so $\mathrm{Ni}(\mathrm{PyS})_{3} \mathrm{H}^{-}$and $\mathrm{Ni}(\mathrm{PyS})_{3} \mathrm{H}^{\mathrm{N}}$ have a triplet ground 
state with two unpaired electrons (Figure 3-5). When $\mathrm{Ni}(\mathrm{PyS})_{3} \mathrm{H}^{\mathrm{N}}$ was optimized as a singlet, the geometry changed to square planar with dechelation of two ligands and the complex was $7.0 \mathrm{kcal} / \mathrm{mol}$ higher energy than the triplet.

Intermediate $\mathrm{Ni}(\mathrm{PyS})_{3} \mathrm{H}^{\mathrm{N}-}$, could be either a doublet, with an unpaired electron on the metal, or a quartet with one unpaired electron on a ligand and two on the metal. The geometry was optimized for the complex in both spin states. Many redox catalysts operate through redox active (non-innocent) ligands. ${ }^{173,174}$ Spin localization can be difficult to determine experimentally for intermediates not long-lived enough for electron paramagnetic resonance (EPR) experiments, however localization of spin density can be determined through computationally generated spin density maps.

Spin density maps were generated to localize the electron density of the unpaired electrons (Figure 3-5). The geometry optimizations of $\mathrm{Ni}(\mathrm{PyS})_{3} \mathrm{H}^{\mathrm{N}-}$ as a doublet and
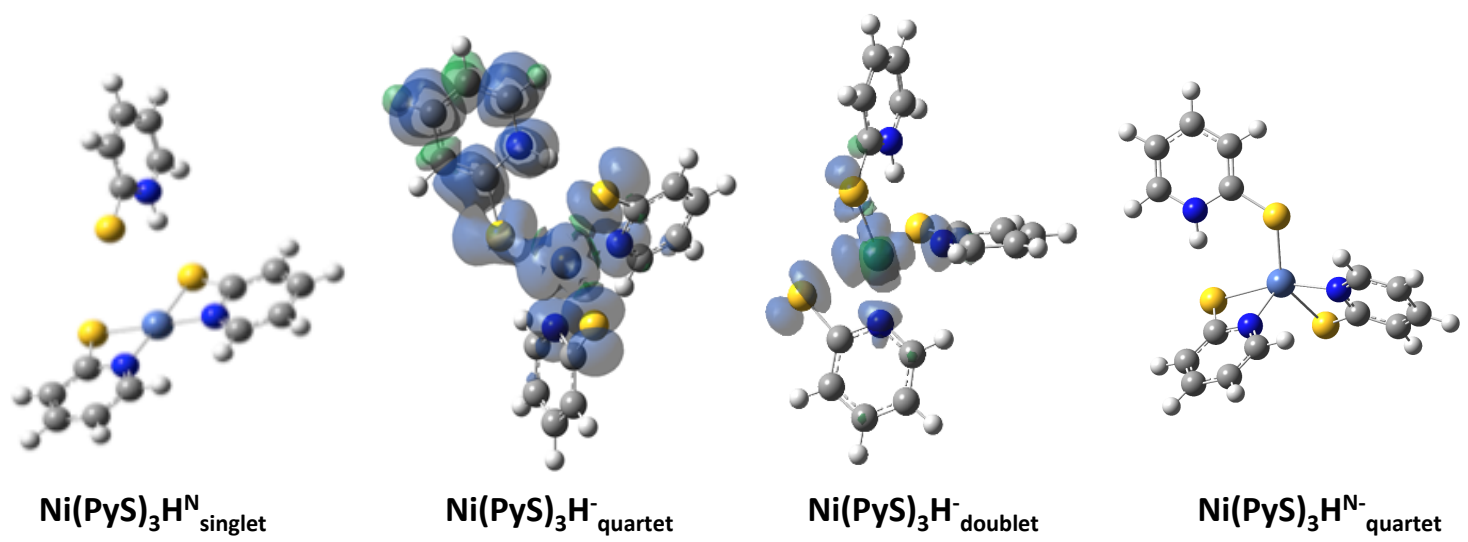

$\mathrm{Ni}(\mathrm{PyS})_{3} \mathrm{H}_{\text {quartet }}$

$\mathrm{Ni}(\mathrm{PyS})_{3} \mathrm{H}_{\text {doublet }}$

$\mathrm{Ni}(\mathrm{PyS})_{3} \mathrm{H}^{\mathrm{N}-}$ quartet

Figure 3-5: Optimized structure of $\mathrm{Ni}(\mathrm{PyS})_{3} \mathrm{H}^{\mathrm{N}}$ singlet. Electron spin density map of $\mathrm{Ni}(\mathrm{PyS})_{3} \mathrm{H}^{\mathrm{N}-}$ in the quartet spin state and doublet spin state. Optimized structure of $\mathrm{Ni}(\mathrm{PyS})_{3} \mathrm{H}^{\mathrm{N}-}$ in a quartet spin state 
quartet show minimal change in structure. However, from the spin density maps it is evident that the electron density of the doublet of complex $\mathrm{Ni}(\mathrm{PyS})_{3} \mathrm{H}^{\mathrm{N}-}$ is heavily localized on the central nickel atom. The quartet spin has electron density more delocalized across the ligands, predominantly on the protonated pyridyl ligand. The doublet zero-point energy is lower by $87.2 \mathrm{kcal} / \mathrm{mol}$ than the quartet. The lower energy of the doublet state indicates that reduction of $\mathrm{Ni}(\mathrm{PyS})_{3} \mathrm{H}^{\mathrm{N}}$ results in a doublet state with electron density on the nickel center, not the ligand.

\subsubsection{Hydride Formation}

The final intermediate in the proposed reaction pathway is a nickel hydride $\left(\mathrm{Ni}(\mathrm{PyS})_{3} \mathrm{H}^{\mathrm{N}} \mathrm{H}^{\mathrm{Ni}-}\right)$ formed through a second reduction and protonation. Experimentally the hydride has not been isolated but is thought to form through a concerted proton coupled electron transfer (PCET) step. ${ }^{62}$ The hydride $\left(\mathrm{Ni}(\mathrm{PyS})_{3} \mathrm{H}^{\mathrm{N}} \mathrm{H}^{\mathrm{Ni}-}\right)$ could be formed in one PCET step, or in two sequential steps, protonation and reduction. ${ }^{175,176}$

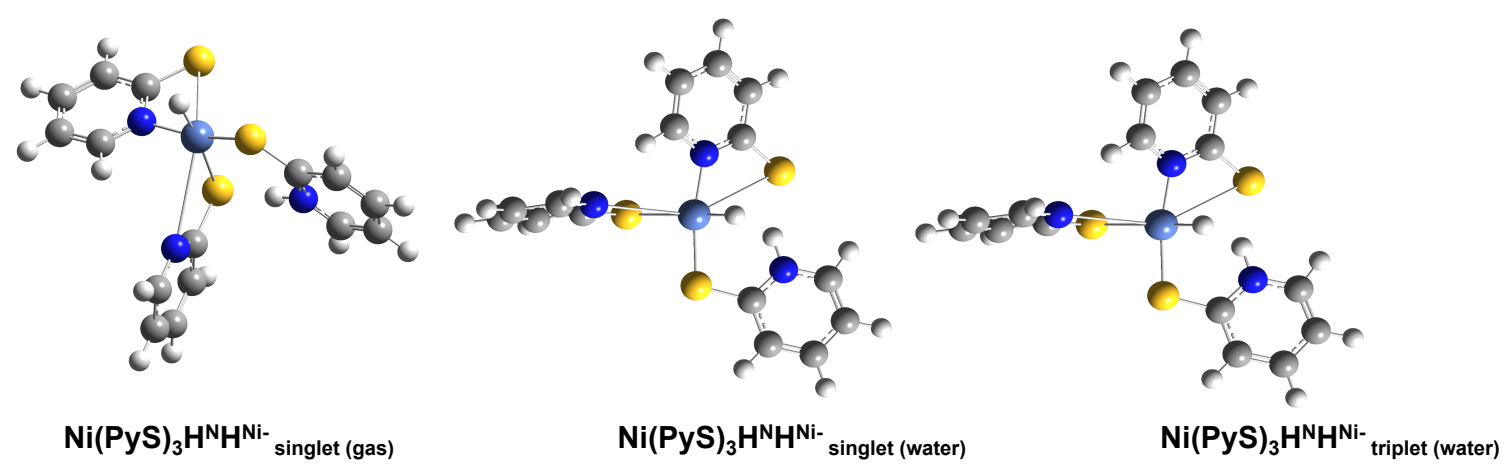

Figure 3-6: Optimized structures of $\mathrm{Ni}(\mathrm{PyS})_{3} \mathrm{H}^{\mathrm{N}} \mathrm{H}^{\mathrm{Ni}-}{ }_{\text {singlet (gas) }}, \mathrm{Ni}(\mathrm{PyS})_{3} \mathrm{H}^{\mathrm{N}} \mathrm{H}^{\mathrm{Ni}-}$ singlet (water) and $\mathrm{Ni}(\mathrm{PyS})_{3} \mathrm{H}^{\mathrm{N}} \mathrm{H}^{\mathrm{Ni}-}$ triplet (water). 
$\mathrm{Ni}(\mathrm{PyS})_{3} \mathrm{H}^{\mathrm{N}} \mathrm{H}^{\mathrm{Ni}-}$ was optimized as a triplet with a water solvation model as well as a singlet in both solvent and the gas phase (Figure 3-6). Optimized geometries for the reduced compound, $\mathrm{Ni}(\mathrm{PyS})_{3} \mathrm{H}^{\mathrm{N} 2-}$, and the protonated compound, $\mathrm{Ni}(\mathrm{PyS})_{3} \mathrm{H}^{\mathrm{N}} \mathrm{H}^{\mathrm{Ni}}$, were found to give stable structures suggesting a possible sequential reaction pathway (Figure 3-7).

Considering these intermediates the following options were considered: A) reduction of $\mathrm{Ni}(\mathrm{PyS})_{3} \mathrm{H}^{\mathrm{N}-}$ to yield complex $\mathrm{Ni}(\mathrm{PyS})_{3} \mathrm{H}^{\mathrm{N} 2-}$, then addition of a proton at the nickel center to yield complex $\mathrm{Ni}(\mathrm{PyS})_{3} \mathrm{H}^{\mathrm{N}} \mathrm{H}^{\mathrm{Ni}-}$, B) reduction of $\mathrm{Ni}(\mathrm{PyS})_{3} \mathrm{H}^{\mathrm{N}-}$ with concerted migration of the proton to the nickel, to yield complex $\mathrm{Ni}(\mathrm{PyS})_{3} \mathrm{H}^{\mathrm{Ni} 2-}$ and subsequent protonation to yield complex $\mathrm{Ni}(\mathrm{PyS})_{3} \mathrm{H}^{\mathrm{N}} \mathrm{H}^{\mathrm{Ni}-} \mathrm{C}$ ) protonation of the nickel center of $\mathrm{Ni}(\mathrm{PyS})_{3} \mathrm{H}^{\mathrm{N}-}$ to yield complex $\mathrm{Ni}(\mathrm{PyS})_{3} \mathrm{H}^{\mathrm{N}} \mathrm{H}^{\mathrm{Ni}}$, then reduction of the complex to again form $\mathrm{Ni}(\mathrm{PyS})_{3} \mathrm{H}^{\mathrm{N}} \mathrm{H}^{\mathrm{Ni}-}$, and $\left.\mathrm{D}\right)$ concerted PCET, which was modeled by addition of
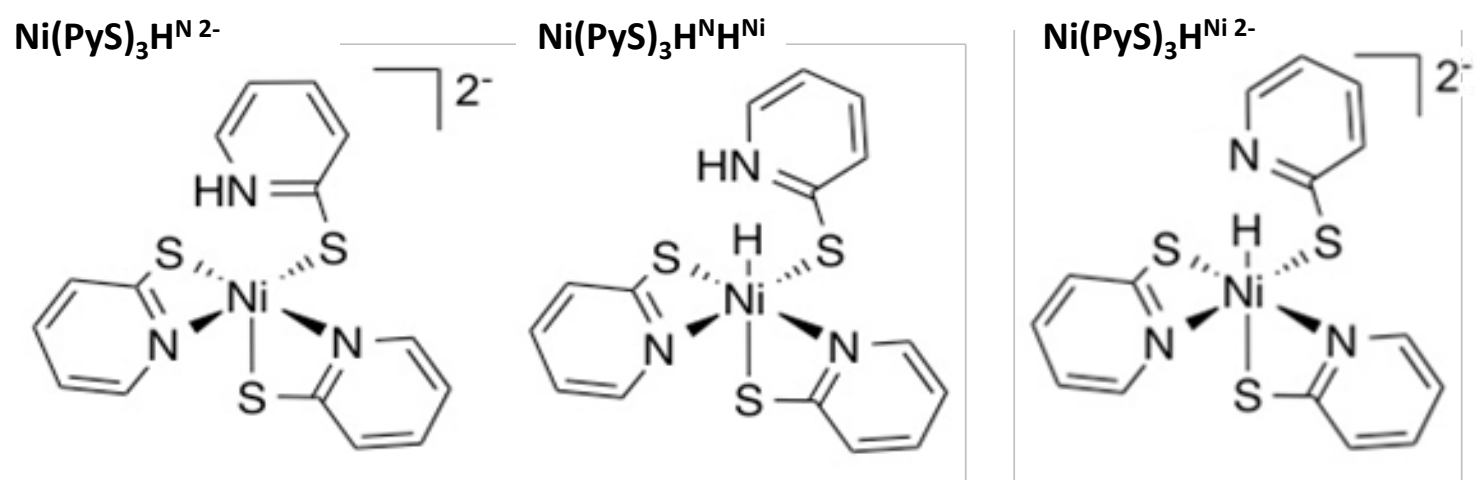

Figure 3-7: PCET alternative intermediates: second reduction, $\mathrm{Ni}(\mathrm{PyS})_{3} \mathrm{H}^{\mathrm{N}}{ }^{2-}$, protonation, $\mathrm{Ni}(\mathrm{PyS})_{3} \mathrm{H}^{\mathrm{N}} \mathrm{H}^{\mathrm{Ni}}$, and reduction with concerted proton migration, $\mathrm{Ni}(\mathrm{PyS})_{3} \mathrm{H}^{\mathrm{Ni} 2-}$. 
a proton at the nickel center and simultaneous addition of an electron. Note the final intermediate, $\mathrm{Ni}(\mathrm{PyS})_{3} \mathrm{H}^{\mathrm{N}} \mathrm{H}^{\mathrm{Ni}-}$, is the same in all four options.

To begin, we consider reduction of $\mathrm{Ni}(\mathrm{PyS})_{3} \mathrm{H}^{\mathrm{N}-}$ to yield $\mathrm{Ni}(\mathrm{PyS})_{3} \mathrm{H}^{\mathrm{N}}{ }^{2-}$. The calculated reduction potentials for $\mathrm{Ni}(\mathrm{PyS})_{3} \mathrm{H}^{\mathrm{N}-}$ is $-2.1 \mathrm{~V}$. Under experimental photocatalytic conditions, electron transfer is thought to occur through a reductive quenching mechanism such that the electrons would come from reduced dye, fluorescein, at a potential of $-1.3 \mathrm{~V} .{ }^{89}$ This would not have enough potential to reduce $\mathrm{Ni}(\mathrm{PyS})_{3} \mathrm{H}^{\mathrm{N}-}$. Due to the high reduction potential for $\mathrm{Ni}(\mathrm{PyS})_{3} \mathrm{H}^{\mathrm{N}-}$, we no longer consider option $\mathrm{A}$.

Option B, proton transfer from the pyridyl nitrogen to the metal center with $\mathrm{Ni}(\mathrm{PyS})_{3} \mathrm{H}^{\mathrm{N}-}$ reduction, results in a hydride intermediate, $\mathrm{Ni}(\mathrm{PyS})_{3} \mathrm{H}^{\mathrm{Ni2}-}$ that is $-42.14 \mathrm{kcal} / \mathrm{mol}$ more stable than complex $\mathrm{Ni}(\mathrm{PyS})_{3} \mathrm{H}^{\mathrm{N} 2-}$. Concerted proton transfer to the $\mathrm{Ni}$ and reduction has a calculated potential of $-1.8 \mathrm{~V}$. Protonation of this complex is
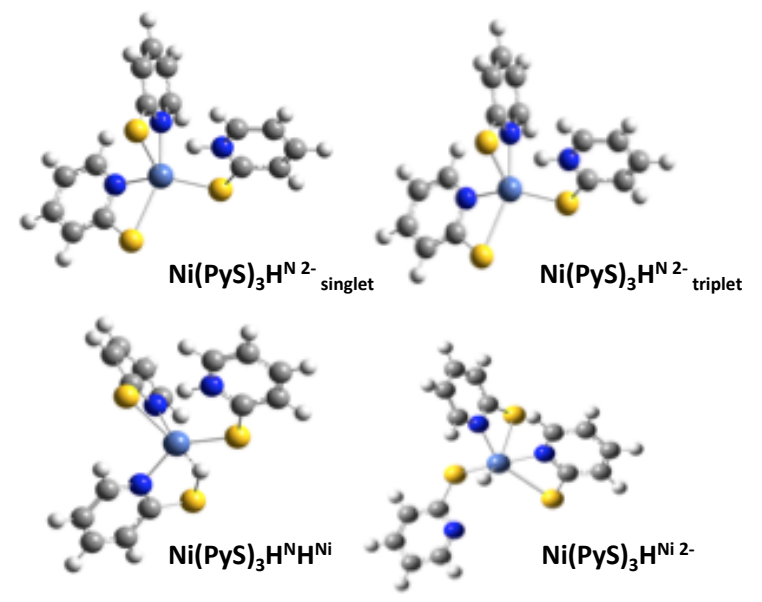

Figure 3-8: Optimized structures of $\mathrm{Ni}(\mathrm{PyS})_{3} \mathrm{H}^{\mathrm{N}}{ }^{2-}{ }_{\text {singlet, }} \mathrm{Ni}(\mathrm{PyS})_{3} \mathrm{H}^{\mathrm{N}} \quad{ }^{2-}$ triplet, $\mathrm{Ni}(\mathrm{PyS})_{3} \mathrm{H}^{\mathrm{N}} \mathrm{H}^{\mathrm{Ni}}$ and $\mathrm{Ni}(\mathrm{PyS})_{3} \mathrm{H}^{\mathrm{Ni} 2-}$. 
unfavorable by $30.49 \mathrm{kcal} / \mathrm{mol}$. Attempts to model an intermolecular PCET reaction with an explicit water molecule did not optimize to a protonated structure.

Option C, formation of $\mathrm{Ni}(\mathrm{PyS})_{3} \mathrm{H}^{\mathrm{N}} \mathrm{H}^{\mathrm{Ni}}$, is exergonic by $11.96 \mathrm{kcal} / \mathrm{mol}$, this corresponds to a pKa of 8.8 for the Ni-H on compound $\mathrm{Ni}(\mathrm{PyS})_{3} \mathrm{H}^{\mathrm{N}} \mathrm{H}^{\mathrm{Ni}}$.

$$
\mathrm{Ni}(\mathrm{PyS})_{3} \mathrm{H}^{\mathrm{N-}}+\mathrm{H}^{+} \rightarrow \mathrm{Ni}(\mathrm{PyS})_{3} \mathrm{H}^{\mathrm{N}} \mathrm{H}^{\mathrm{Ni}} \Delta \mathrm{G}^{\circ}=-11.96 \mathrm{kcal} / \mathrm{mol} \text {, pKa } 8.8
$$

Experimentally, the reaction occurs at a $\mathrm{pH}$ of $12 .{ }^{89}$ Even considering a $2.6 \mathrm{pKa}$ unit margin of error, equilibrium likely lies towards having higher concentrations of $\mathrm{Ni}(\mathrm{PyS})_{3} \mathrm{H}^{\mathrm{N}-}$, rather than protonated compound $\mathrm{Ni}(\mathrm{PyS})_{3} \mathrm{H}^{\mathrm{N}} \mathrm{H}^{\mathrm{Ni}}$. Interestingly Eisenberg et al noted a small reduction wave in the $\mathrm{CV}$ around $-1.0 \mathrm{~V}$ that did not show any catalytic behavior and that disappeared upon neutralization. ${ }^{62}$ Our results indicate this

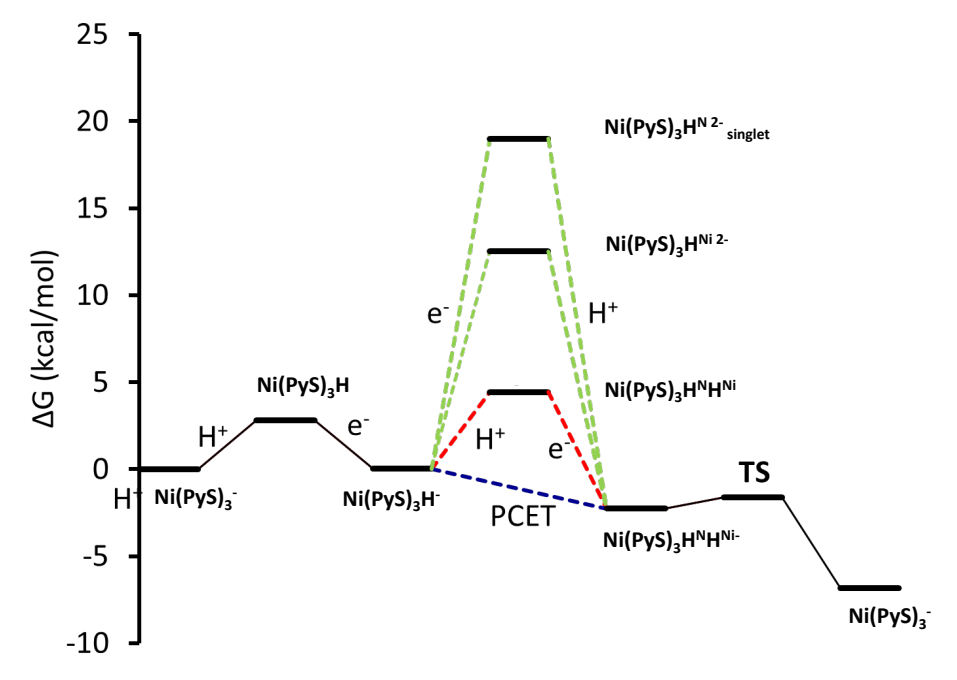

Figure 3-9: Energy coordinate diagram for alternative paths to PCET. Red trace: $\mathrm{Ni}(\mathrm{PyS})_{3} \mathrm{H}^{\mathrm{N}-}$ is first protonated $\left(\mathrm{Ni}(\mathrm{PyS})_{3} \mathrm{H}^{\mathrm{N}} \mathrm{H}^{\mathrm{Ni}}\right)$, then reduced at the nickel center. Green trace: $\mathrm{Ni}(\mathrm{PyS})_{3} \mathrm{H}^{\mathrm{N}-}$ is reduced to $\mathrm{Ni}(\mathrm{PyS})_{3} \mathrm{H}^{\mathrm{N} 2-}$, followed by proton migration to $\mathrm{Ni}(\mathrm{PyS})_{3} \mathrm{H}^{\mathrm{Ni} 2-}$. Blue trace: concerted PCET. 
peak may correspond to reduction of $\mathrm{Ni}(\mathrm{PyS})_{3} \mathrm{H}^{\mathrm{N}} \mathrm{H}^{\mathrm{Ni}}$ that has a calculated reduction potential of $-1.0 \mathrm{~V}$. At $\mathrm{pH} 12$ protonation of $\mathrm{Ni}(\mathrm{PyS})_{3} \mathrm{H}^{\mathrm{N}-}$ is only exothermic by 4.41 $\mathrm{kcal} / \mathrm{mol}$. Although only small amounts of $\mathrm{Ni}(\mathrm{PyS})_{3} \mathrm{H}^{\mathrm{N}} \mathrm{H}^{\mathrm{Ni}}$ may be formed it would be easily reduced, driving this reaction.

Finally, Equation 10, concerted protonation and reduction was calculated to require $2.3 \mathrm{kcal} / \mathrm{mol}$. In the absence of kinetic data, we hypothesize that the transition from $\mathrm{Ni}(\mathrm{PyS})_{3} \mathrm{H}^{\mathrm{N}-}$ to $\mathrm{Ni}(\mathrm{PyS})_{3} \mathrm{H}^{\mathrm{N}} \mathrm{H}^{\mathrm{Ni}-}$ will have a lower barrier of activation than the transition from $\mathrm{Ni}(\mathrm{PyS})_{3} \mathrm{H}^{\mathrm{N}} \mathrm{H}^{\mathrm{Ni}}$ to $\mathrm{Ni}(\mathrm{PyS})_{3} \mathrm{H}^{\mathrm{N}} \mathrm{H}^{\mathrm{Ni}-}$ (Figure 3-9).

$$
\mathrm{Ni}(\mathrm{PyS})_{3} \mathrm{H}^{\mathrm{N}-}+\mathrm{e}^{-}+\mathrm{H}^{+} \rightarrow \mathrm{Ni}(\mathrm{PyS})_{3} \mathrm{H}^{\mathrm{Ni}} \quad \Delta \mathrm{G}^{\circ}=2.35 \mathrm{kcal} / \mathrm{mol}
$$
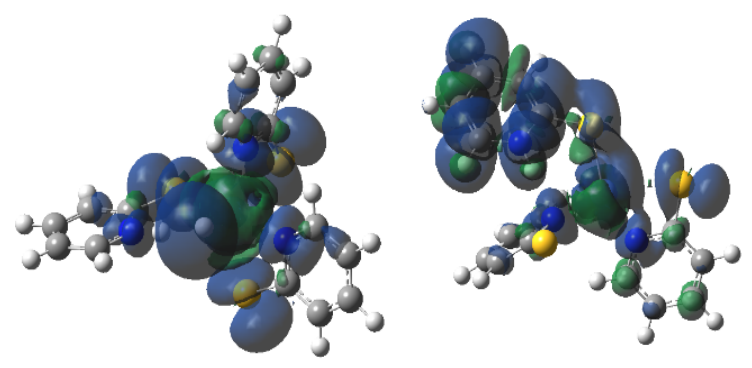

Figure 3-10: Spin density map for $\mathrm{Ni}(\mathrm{PyS})_{3} \mathrm{H}^{\mathrm{N}} \mathrm{H}^{\mathrm{Ni}-}$, triplet, left, and $\mathrm{Ni}(\mathrm{PyS})_{3} \mathrm{H}^{\mathrm{Ni}}$ 2- $^{2}$, triplet, right, showing spin density located heavily on the hydride and protonated $\mathrm{PyS}^{-}$ ligands respectively.

The ground state of the hydride, $\mathrm{Ni}(\mathrm{PyS})_{3} \mathrm{H}^{\mathrm{N}} \mathrm{H}^{\mathrm{Ni}-}$, and the doubly reduced compound, $\mathrm{Ni}(\mathrm{PyS})_{3} \mathrm{H}^{\mathrm{N} 2-}$, could be either a singlet state or a triplet state. Knowing where electron density is localized is important for ligand design. The energy of the triplet state for $\mathrm{Ni}(\mathrm{PyS})_{3} \mathrm{H}^{\mathrm{N}} \mathrm{H}^{\mathrm{Ni}-}$ is $61.7 \mathrm{kcal} / \mathrm{mol}$ lower in energy than the singlet state. The spin density map of $\mathrm{Ni}(\mathrm{PyS})_{3} \mathrm{H}^{\mathrm{N}} \mathrm{H}^{\mathrm{Ni}-}$ in a triplet state shows electron density on both the metal 
and the hydride, supporting the hydride designation of this complex (Figure 3-10). Likewise, the triplet state of $\mathrm{Ni}(\mathrm{PyS})_{3} \mathrm{H}^{\mathrm{N} 2-}$ is $35.6 \mathrm{kcal} / \mathrm{mol}$ lower in energy than the singlet. The electron density is located primarily on the protonated ligand. These electron density maps suggest that unlike the first reduction, which was centered on the nickel, the second reduction is ligand based.

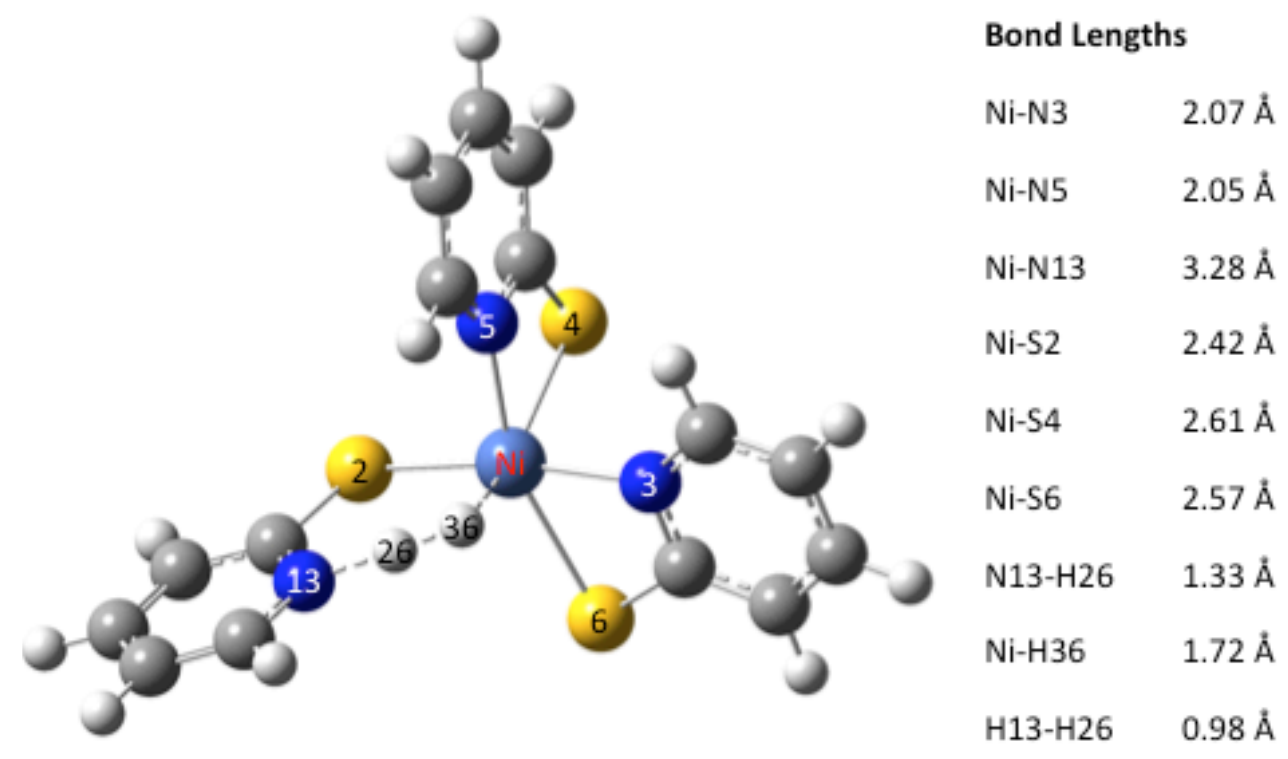

Figure 3-11: Structure of transition state between $\mathrm{Ni}(\mathrm{PyS})_{3} \mathrm{H}^{\mathrm{N}} \mathrm{H}^{\mathrm{Ni}-}$ and $\mathrm{Ni}(\mathrm{PyS})_{3}{ }^{-}+\mathrm{H}_{2}$ with bond lengths.

\subsubsection{Hydrogen release}

After formation of the nickel hydride, $\mathrm{Ni}(\mathrm{PyS})_{3} \mathrm{H}^{\mathrm{N}} \mathrm{H}^{\mathrm{Ni}-}$, the catalyst has the two electrons and two protons required to produce hydrogen. In the octahedral complex $\mathrm{Ni}(\mathrm{PyS})_{3} \mathrm{H}^{\mathrm{N}} \mathrm{H}^{\mathrm{Ni}-}$ the proton on the pyridyl nitrogen and nickel are close together (1.44 $\AA$ ). In the optimized structure of the transition state the $\mathrm{H}-\mathrm{H}$ bond length is $0.98 \AA$. The Ni-H 
bond length has extended to $1.72 \AA$, and the N-H bond length is $1.33 \AA$ (Figure 3-11). The transition state is only $0.64 \mathrm{kcal} / \mathrm{mol}$ higher in energy than $\mathrm{Ni}(\mathrm{PyS})_{3} \mathrm{H}^{\mathrm{N}} \mathrm{H}^{\mathrm{Ni}-}$. The release of hydrogen from the transition state is exergonic by $5.2 \mathrm{kcal} / \mathrm{mol}$, suggesting that hydrogen elimination has a low barrier of activation.

\subsubsection{Complete Catalytic Cycle}

Thermodynamic cycles were used to determine the most catalytically favored pathway. The reduction potentials and $\mathrm{p} K_{a}$ 's connecting each intermediate are shown in Figure 3-12. ${ }^{177,178}$ We calculated that reduction of $\mathrm{Ni}(\mathrm{PyS})_{3}{ }^{-}$prior to protonation would require a potential of $-1.9 \mathrm{~V}$. Thus, it is evident that initial protonation is more favorable than initial reduction of $\mathrm{Ni}(\mathrm{PyS})_{3}{ }^{-}$. This is in agreement with electrochemical experimental data indicating that without acid present in solution, no cyclic voltammetry wave is observed at potentials less negative that $-2.0 \mathrm{~V} .{ }^{89}$ The calculated $\mathrm{p} K_{a}$ of $\mathrm{Ni}(\mathrm{PyS})_{3} \mathrm{H}^{\mathrm{N}}$ is 9.9 , which is in relatively good agreement with the experimentally measured $\mathrm{p} K_{a}$ of 12 . Given the 2.6 unit margin of error, protonation of compound $1^{-}$is likely at $\mathrm{pH} 12$, which was used in the photocatalytic experiment. 
From experiment it is still unclear if the formation of the hydride, $\mathrm{Ni}(\mathrm{PyS})_{3} \mathrm{H}^{\mathrm{N}} \mathrm{H}^{\mathrm{Ni}-}$ occurs through sequential or concurrent protonation and reduction. Structures of protonated intermediate $\mathrm{Ni}(\mathrm{PyS})_{3} \mathrm{H}^{\mathrm{N}} \mathrm{H}^{\mathrm{Ni}}$ and reduced intermediates $\mathrm{Ni}(\mathrm{PyS})_{3} \mathrm{H}^{\mathrm{N} 2-}$ and $\mathrm{Ni}(\mathrm{PyS})_{3} \mathrm{H}^{\mathrm{Ni}}{ }^{2-}$ were optimized suggesting these may be stable intermediates and sequential PCET may occur. However, the reduction potential of $\mathrm{Ni}(\mathrm{PyS})_{3} \mathrm{H}^{\mathrm{N-}}$ to make $\mathrm{Ni}(\mathrm{PyS})_{3} \mathrm{H}^{\mathrm{N} 2-}$ and $\mathrm{Ni}(\mathrm{PyS})_{3} \mathrm{H}^{\mathrm{Ni} 2-}$ are $-2.1 \mathrm{~V}$ and $-1.8 \mathrm{~V}$ respectively, making formation of these intermediates unlikely (Figure 3-12). The protonated compound $\mathrm{Ni}(\mathrm{PyS})_{3} \mathrm{H}^{\mathrm{N}} \mathrm{H}^{\mathrm{Ni}}$, if present in solution, is likely found in low concentrations, however the low reduction

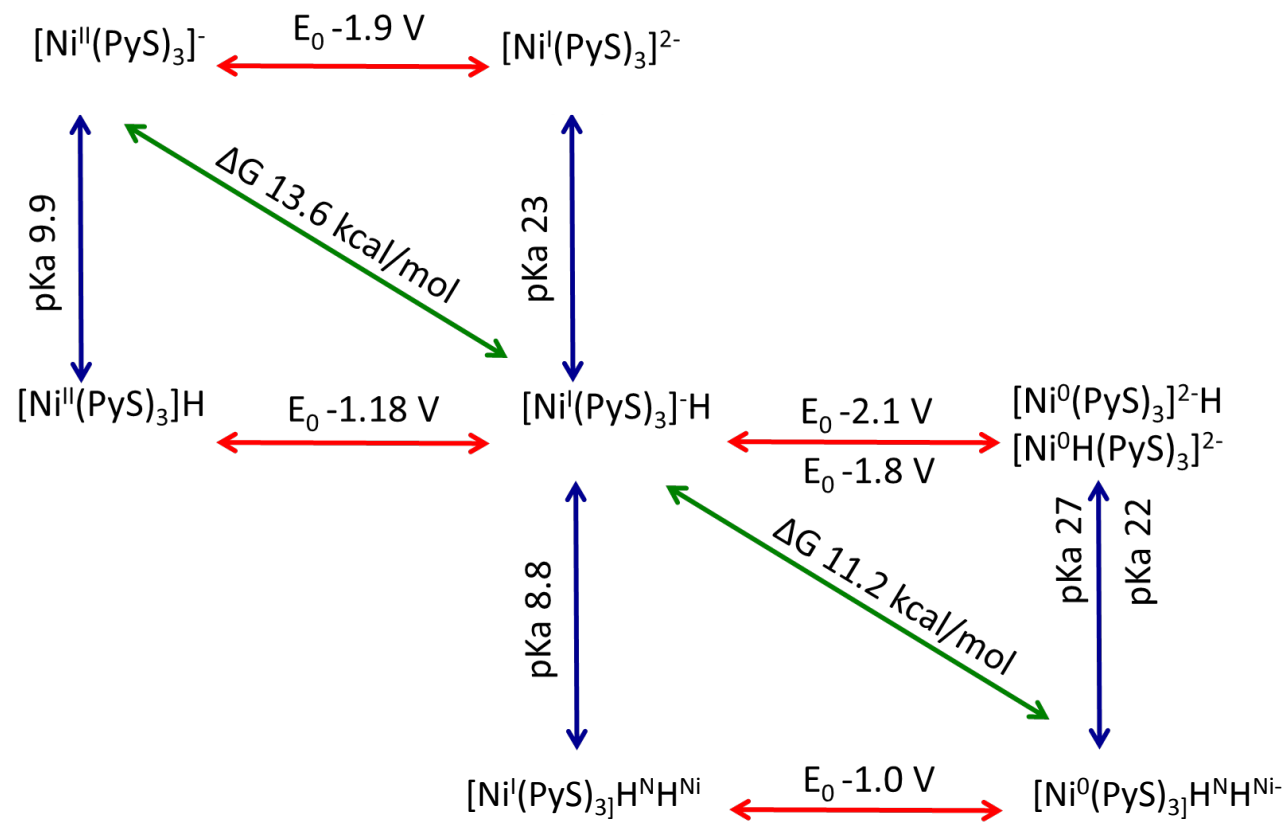

Figure 3-12: Thermodynamic cycle for $\mathrm{H}_{2}$ production by $\mathrm{Ni}(\mathrm{PyS})_{3}$. Electrochemical data reported vs SCE. 
potential would drive this reaction toward the hydride $\mathrm{Ni}(\mathrm{PyS})_{3} \mathrm{H}^{\mathrm{N}} \mathrm{H}^{\mathrm{Ni}}$. Additionally, electrochemical data indicates the presence of a second reduction at $-1.0 \mathrm{~V}$. Our calculated reduction potential of $-1.0 \mathrm{~V}$ for $\mathrm{Ni}(\mathrm{PyS})_{3} \mathrm{H}^{\mathrm{N}} \mathrm{H}^{\mathrm{Ni}}$ indicates correct identification of this reduction wave. Taking into consideration the $\mathrm{p} K_{a}$ 's and reduction potentials a sequential PCET where protonation occurs before reduction is most consistent with experimental results. However, the overall $\Delta \mathrm{G}$ of $2.35 \mathrm{kcal} / \mathrm{mol}$ for PCET, where $\mathrm{Ni}(\mathrm{PyS})_{3} \mathrm{H}^{\mathrm{N-}}$ becomes $\mathrm{Ni}(\mathrm{PyS})_{3} \mathrm{H}^{\mathrm{N}} \mathrm{H}^{\mathrm{Ni}-}$, suggests a low barrier to a concerted mechanism. The structure of the hydride $\mathrm{Ni}(\mathrm{PyS})_{3} \mathrm{H}^{\mathrm{N}} \mathrm{H}^{\mathrm{Ni}-}$ shows the protons in close proximity, requiring very little energy to generate the transition state for hydrogen elimination to regenerate the initial catalyst $\mathrm{Ni}(\mathrm{PyS})_{3}{ }^{-}$.

These calculations suggest two main routes to improve catalyst design, first sterically hindering the space around the nickel could prevent coordination of a hydroxide that forms a complex that cannot continue through the catalytic cycle. Secondly, the high energy steps are protonations, thus increasing the basicity of the ligand may result in a more active catalyst. Also the reduction potentials determined suggest that a less reducing photosensitizer would still provide the potential needed to drive this reaction and could allow for ideal matching of photosensitizer and catalysts. Further studies into this hypothesis are underway.

\subsection{Conclusions}

This study explored the $\mathrm{Ni}(\mathrm{PyS})_{3}{ }^{-}$intermediates throughout the catalytic cycle of proton reduction. Specifically, DFT calculations support the experimentally proposed 
catalytic cycle while providing insight into intermediate complex geometries and electron localization of the reduced intermediates. Catalyst protonation at the pyridyl nitrogen is required to lower the reduction potential of the catalyst so that it can be reduced by the photosensitizer. This protonation leads to ligand dechelation, leaving a vacant coordination site. Water coordination following initial protonation is thermodynamically unfavorable, however hydroxide coordination is exothermic and could lead to an intermediate that would not continue through the catalytic cycle. The spin density map of the reduced catalyst $\left(\mathrm{Ni}(\mathrm{PyS})_{3} \mathrm{H}^{\mathrm{N}-}\right)$ reveals electron density is localized at the metal center. The formation of the nickel-hydride intermediate $\mathrm{Ni}(\mathrm{PyS})_{3} \mathrm{H}^{\mathrm{N}} \mathrm{H}^{\mathrm{Ni}-}$ occurs through sequential proton-electron transfer, and the hydride nature was confirmed through a spin density map. Hydrogen elimination from this species is not energetically demanding, as demonstrated through determination of the transition state energy. Through the use of DFT calculations, we elucidated features of intermediates along the catalytic cycle of $\mathrm{Ni}(\mathrm{PyS})_{3}{ }^{-}$which were experimentally unexplored. 


\section{CHAPTER 4}

\section{MODIFICATION OF PYRIDINETHIOLATE LIGANDS}

\section{Investigation into the effect of ligand modification on derivatives of a $\mathrm{Ni}(\mathrm{PyS})_{3}{ }^{-}$}

proton reduction catalyst using joint computational and experimental methods

This work is published in ACS Journal of Physical Chemistry A.

Virca, C. N.; Lohmolder, J. R.; Tsang, J. B.; Davis, M. M.; McCormick, T. M. Effect of

Ligand Modification on the Mechanism of Electrocatalytic Hydrogen Production by Ni(pyridinethiolate) ${ }_{3}{ }^{-}$Derivatives. J. Phys. Chem. A Just Accept. Manuscr. 2018.

\subsection{Introduction}

Computational design of molecular hydrogen evolution catalysts made from earth abundant materials is an active area of research with significance for driving the development of effective renewable-energy storage technologies. ${ }^{63,66,67,80,144,152,163,179-181}$ Rationally designed homogenous catalysts with computationally predicted properties could be formulated to operate under ideal conditions, at neutral $\mathrm{pH}$ and with low overpotentials. ${ }^{166,182,183}$ One goal of computationally driven catalyst design is to elucidate reaction mechanisms of catalysts by determining the $\mathrm{p} K_{a}$ 's and reduction potentials of intermediates for each possible protonation and reduction step along the catalytic cycle. Given defined experimental parameters such as $\mathrm{pH}$, the energy change of each step can be calculated and used to generate reaction coordinate diagrams. ${ }^{79,180}$ Mechanistic insights 
are obtained through study of the molecular geometry, energy, and electronic structure of reaction intermediates. ${ }^{80,84,127,163,178,180,184-187}$

Nickel-pyridinethiolate $\left(\mathrm{Ni}(\mathrm{PyS})_{3}{ }^{-}\right)$, and simple derivatives of this compound, have been shown to be effective hydrogen evolution catalysts, under both photocatalytic and electrocatalytic conditions, capable of operating at $\mathrm{pH} 12$ and with relatively low overpotentials. $^{62,155}$ The work on $\mathrm{Ni}(\mathrm{PyS})_{3}{ }^{-}$detailed in Chapter 3 supports the catalytic Chemical-Electrochemical-Chemical-Electrochemical (CECE) mechanism of hydrogen production put forth by Eisenberg and co-workers under the given experimental conditions, ${ }^{188}$ as calculated $\mathrm{pK}_{\mathrm{a}}$ values and reduction potentials correlate well to those determined experimentally. In this work, we build on our previous study by probing how $\mathrm{p} K_{a}$ and $\mathrm{E}^{0}$ are affected by modifying the pyridine ligand moiety with electron donating and withdrawing substituents spanning a range of Hammett constants. It has been previously shown that a methyl-substituted catalyst results in increased photocatalytic hydrogen production rates, in this work we suggest an alternative mechanism for this derivative. $^{62}$ The investigated substituents are as follows: 3-(trifluoromethyl)pyridine-2thiol (3- $\left.\mathrm{CF}_{3} \mathrm{PyS}\right)$, 5-(trifluoromethyl)pyridine-2-thiol $\left(5-\mathrm{CF}_{3} \mathrm{PyS}\right),{ }^{62}$ 6-mercaptopyridine3-carboxylic acid (6-S-3-COOHPyS), 2-mercaptopyridine-3-carboxylic acid (2-S-3COOHPyS), 5-chloropyridine-2-thiol (5-ClPyS), ${ }^{62}$ 6-methylpyridine-2-thiol (6$\left.\mathrm{CH}_{3} \mathrm{PyS}\right)^{62}$ (structures in Figure 4-1 and Table 4-1). The catalytic cycles of these compounds were studied computationally and the complexes were subsequently synthesized and characterized experimentally. 
The previously supported CECE mechanism of $\mathrm{Ni}(\mathrm{PyS})_{3}{ }^{-}$serves as the starting point for analysis of the catalytic cycle. The most notable finding of our study is that for the most electron donating substituent $6-\mathrm{CH}_{3} \mathrm{PyS}$, agreement between experimental and theoretical data suggests a unique CCEE mechanism. Initial protonation and reduction steps are studied by visualization of the frontier molecular orbitals, spin density maps, $\mathrm{p} K_{a}$ values of various sites, $\mathrm{E}^{0}$ values, and thermodynamic reaction coordinate diagrams for reaction intermediates. Remaining protonation and reduction steps are discussed and

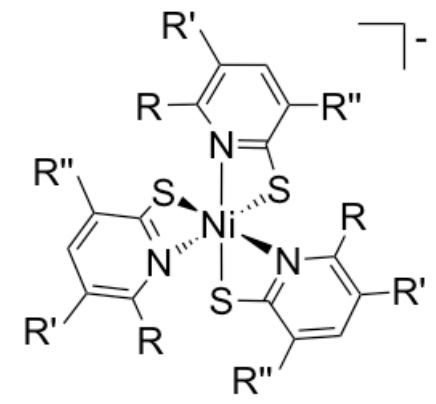

Figure 4-1: Schematic of $\mathrm{Ni}(\mathrm{PyS})_{3}{ }^{-}$compound, R groups are given in Table 4-1

Table 4-1: Specified substitutions on $\mathrm{Ni}(\mathrm{PyS})_{3}{ }^{-}$schematic with associated Hammett constants. $^{189}$

\begin{tabular}{|c|c|c|c|c|}
\hline & $\mathbf{R}$ & $\mathbf{R}^{\prime}$ & $\mathbf{R}^{\prime}$ & $\boldsymbol{\sigma}$ \\
\hline$\left(3-\mathrm{CF}_{3} \mathrm{PyS}\right)$ & $-\mathrm{H}$ & $-\mathrm{H}$ & $-\mathrm{CF}_{3}$ & 0.43 \\
\hline$\left(5-C_{3} P y S\right)$ & $-\mathrm{H}$ & $-\mathrm{CF}_{3}$ & $-\mathrm{H}$ & 0.43 \\
\hline (6-S-3-COOHPyS) & $-\mathrm{H}$ & $-\mathrm{COOH}$ & $-\mathrm{H}$ & 0.37 \\
\hline (2-S-3-COOHPyS) & $-\mathrm{H}$ & $-\mathrm{H}$ & $-\mathrm{COOH}$ & 0.37 \\
\hline (5-CIPyS) & $-\mathrm{H}$ & $-\mathrm{Cl}$ & $-\mathrm{H}$ & 0.37 \\
\hline$\left(6-\mathrm{CH}_{3} \mathrm{PyS}\right)$ & $-\mathrm{CH}_{3}$ & $-\mathrm{H}$ & $-\mathrm{H}$ & -0.07 \\
\hline
\end{tabular}


the effect of $\mathrm{p} K_{a}$ and $\mathrm{E}^{0}$ on experimentally determined TOFs is proposed. We use this data to investigate the relationship between $\mathrm{E}^{0}, \mathrm{p} K_{a}$ and $\sigma$ (Hammett constant), used to quantify the effect of the electron donating/withdrawing ability of the ligand substituent.

\subsection{Results}

Compounds $\mathrm{Ni}\left(5-\mathrm{CF}_{3} \mathrm{PyS}\right)_{3}{ }^{-}, \quad \mathrm{Ni}(5-\mathrm{ClPyS})_{3}{ }^{-}, \quad$ and $\mathrm{Ni}\left(6-\mathrm{CH}_{3} \mathrm{PyS}\right)_{3}{ }^{-}$were synthesized as previously described. ${ }^{62}$ Compounds $\mathrm{Ni}\left(3-\mathrm{CF}_{3} \mathrm{PyS}\right)_{3}{ }^{-}$, Ni(6-S-3-COOH $)_{3}{ }^{-}$, and $\mathrm{Ni}(2-\mathrm{S}-3-\mathrm{COOHPyS})_{3}{ }^{-}$were synthesized using a similar procedure, detailed in Chapter 2. Reduction potentials and rates of hydrogen production were determined as

Table 4-2: Computationally determined $\mathrm{p} K_{a}^{\mathrm{t}}$ values and reduction potentials* (V vs $\mathrm{SCE})$ with experimental $\mathrm{p} K_{a}$ 's, reduction potentials, TOFs and overpotentials $\left(\eta_{\text {exp }}\right)$.

\begin{tabular}{|c|c|c|c|c|c|c|c|}
\hline Ligand & $\begin{array}{c}\mathbf{N} \mathbf{p} K_{a} \\
\text { (calc) }\end{array}$ & $\begin{array}{c}\mathbf{S} \mathbf{~ p} K_{a} \\
\text { (calc) }\end{array}$ & $\begin{array}{l}\mathbf{p} \boldsymbol{K}_{a} \\
\text { (exp) }\end{array}$ & $\mathbf{E}_{\text {(calc) }}^{0}$ & $\mathbf{E}_{(\text {exp) }}^{0}$ & TOF s ${ }^{-1}$ & $\eta_{\text {exp }}$ \\
\hline$\left(3-\mathrm{CF}_{3} \mathrm{PyS}\right)$ & 6.3 & -7.7 & $\overline{8.3}$ & -1.34 & -1.26 & 42 & $325 \mathrm{mV}$ \\
\hline$\left(5-\mathrm{CF}_{3} \mathrm{PyS}\right)$ & 6.6 & 1.5 & 7.4 & -1.30 & -1.29 & 53 & $354 \mathrm{mV}$ \\
\hline $\begin{array}{c}\text { (6-S-3- } \\
\text { COOHPyS) }\end{array}$ & 9.9 & -0.2 & 10.3 & -1.36 & -1.13 & 164 & $194 \mathrm{mV}$ \\
\hline $\begin{array}{c}(2-S-3- \\
\text { COOHPyS) }\end{array}$ & 7.0 & 4.5 & 8.6 & -1.37 & -1.25 & 164 & $315 \mathrm{mV}$ \\
\hline (5-CIPyS) & 7.8 & 4.0 & 7.6 & -1.38 & -1.31 & 314 & $375 \mathrm{mV}$ \\
\hline$\left(6-\mathrm{CH}_{3} \mathrm{PyS}\right)$ & 16.3 & 7.6 & 10.7 & -1.55 & -1.09 & 332 & $155 \mathrm{mV}$ \\
\hline
\end{tabular}

${ }_{\mathrm{p}}^{\mathrm{t}} K_{a}$ values calculated from the triplet state. *Electrochemical data in Appendix Figure 2 to Appendix Figure 7. Computed values for formation of the doublet state. $\mathrm{E}^{0}$ taken as the cathodic maximum current with one equivalent of acid. 
described in Chapter 2. Electrocatalytic TOF's determined using this method (Table 4-2) follow the same trends as the photocatalytic TOF previously determined by Eisenberg and coworkers. ${ }^{62}$

To determine the $\mathrm{p} K_{a}$ 's of each derivative, solutions in $1: 1 \mathrm{H}_{2} \mathrm{O} / \mathrm{EtOH}$ with catalyst concentration of the order of $10^{-4} \mathrm{M}$ were fully deprotonated using aqueous $\mathrm{NaOH}$ and the UV-vis absorbance of the deprotonated catalysts was determined. Samples were titrated with aqueous $\mathrm{HCl}$ and the $\mathrm{pH}$ and absorbance spectra were monitored throughout, until complete conversion to the protonated catalyst as noted by no further change in the absorbance spectra. Absorbance spectra of the fully protonated and fully deprotonated catalysts can be seen in Appendix Figure 9 as well as the titration spectra and accompanying plots of the absorbance ratio vs $\mathrm{pH}$ in Appendix Figure 2 to Appendix Figure 7. The $\mathrm{pKa}$ was chosen to be the minimum value of the second derivative of the curve of best fit of the ratio of $\lambda_{\max }$ of the protonated and deprotonated catalysts plotted against $\mathrm{pH}$, which corresponds to its inflection point. Not all of the plots of UV-vis absorbance spectra show a clear isosbestic point in moving from the protonated to the deprotonated species in solution. We attribute this to the presence of isomers of the catalyst in solution caused by the meridional structure. Current work is ongoing to further investigate the effects of having multiple isomers of nickel-based proton reduction catalysts. By using the experimental properties of each derivative we were able to undertake a more focused computational investigation into the mechanism of hydrogen production by these compounds. 


\subsection{Discussion}

\subsubsection{First chemical step}

The first step of the catalytic cycle of hydrogen production by $\mathrm{Ni}(\mathrm{PyS})_{3}{ }^{-}$was previously determined to be protonation. ${ }^{188}$ For each derivative reduction prior to protonation would require large potentials. Under our experimental conditions, reduction was observed for all catalysts using an applied potential of $-1.58 \mathrm{~V}$ vs SCE or less only after a proton source was added (Appendix Figure 10), thus protonation was considered to be the first step in the catalytic cycle of all derivatives. The catalyst could be protonated at a pyridyl nitrogen, or on a sulfur atom. In Chapter 3, exploring the catalytic cycle of $\mathrm{Ni}(\mathrm{PyS})_{3}{ }^{-}$, we supported the experimentally determined site of protonation by comparing $\Delta \mathrm{G}$ for protonation at various possible sites and selecting the most thermodynamically favored option. For $\mathrm{Ni}(\mathrm{PyS})_{3}{ }^{-}$this was found to be on the dechelated pyridyl nitrogen.

Furthermore, protonation at the pyridyl nitrogen is supported by a previously reported single crystal X-ray structure of a similar compound, $\left[\mathrm{Ni}(\mathrm{HpyS})_{4}\right]\left(\mathrm{NO}_{3}\right)_{2} \cdot \mathrm{EtOH}$, which has all four ligands protonated at the pyridyl nitrogen and dechelated. ${ }^{62}$ For all six derivatives, protonation at the pyridyl nitrogen is thermodynamically favored relative to a sulfur atom. Our computed values $\mathrm{p} K_{\mathrm{a}}$ generally agree with experimental data, with the exception of $\mathrm{Ni}\left(6-\mathrm{CH}_{3} \mathrm{PyS}\right)_{3}{ }^{-}$. For $\mathrm{Ni}\left(6-\mathrm{CH}_{3} \mathrm{PyS}\right)_{3}{ }^{-}$neither the computed $\mathrm{p} K_{a}$ for protonation of nitrogen nor sulfur matches the experimentally obtained value. This inconsistency suggests a deviation from the CECE mechanism. 
We have found that $\mathrm{Ni}\left(6-\mathrm{CH}_{3} \mathrm{PyS}\right)_{3}{ }^{-}$follows a unique catalytic mechanism due to the electron donating effect of the methyl substitution on the pyridinethiolate ligands. Although the Hammett constant of a methyl substituent does not differ greatly relative to the Hammett constant of a $\mathrm{H}$ substituent, it appears that this minor increase in electron density allows access to a new mechanism. Interestingly, this catalyst has the highest electrochemical TOF of $332 \mathrm{~s}^{-1}$ (plots of $i_{\text {cat }} / i_{\mathrm{p}}$ used to generate the TOF's can be seen in Appendix Figure 2 to Appendix Figure 7). This follows the previously reported

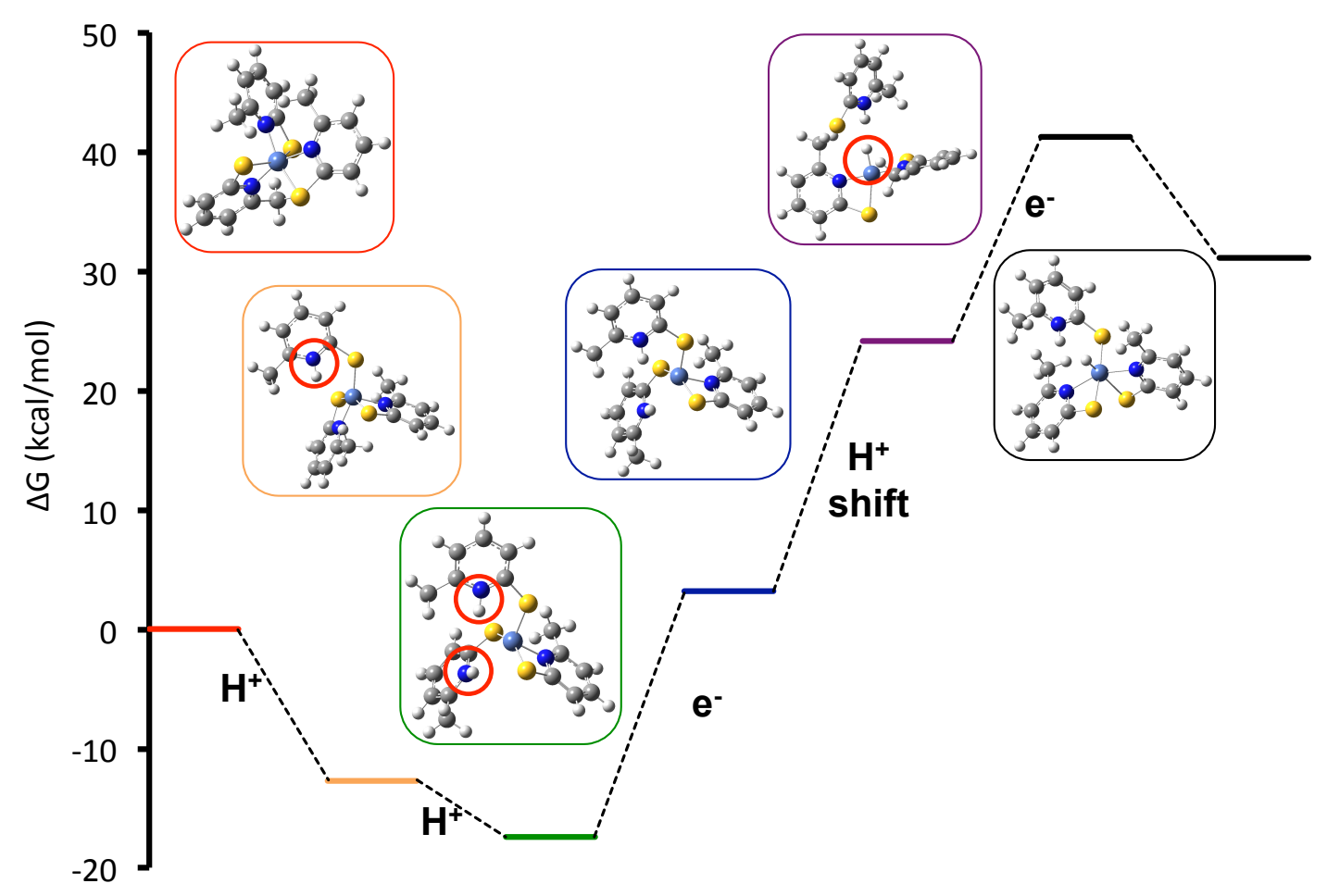

Figure 4-2: Reaction coordinate diagram of the proposed catalytic cycle of hydrogen production by $\mathrm{Ni}\left(6-\mathrm{CH}_{3} \mathrm{PyS}\right)_{3}{ }^{-}$showing CCEE mechanism with proton shift from a ligand nitrogen to the $\mathrm{Ni}$ center (at $\mathrm{pH} 7$ ). 
photocatalytic activity of this catalyst that was found to have the highest TOF out of a series of nickel pyridinethiolate complexes. ${ }^{62}$

We investigated the possible protonation sites for $\mathrm{Ni}\left(6-\mathrm{CH}_{3} \mathrm{PyS}\right)_{3}{ }^{-}$. The cycle begins with $\mathrm{Ni}\left(6-\mathrm{CH}_{3} \mathrm{PyS}\right)_{3}{ }^{-}$in a triplet-spin-state, which will be denoted $\{\mathrm{t}\}$. The tripletspin-state is selected over the singlet-spin-state, $\{s\}$, as it is the lower energy conformation and has the appropriate octahedral geometry (Figure 4-2). As with the other derivatives, protonation of $\mathrm{Ni}\left(6-\mathrm{CH}_{3} \mathrm{PyS}\right)_{3}{ }^{-}\{\mathrm{t}\}$ could be the first step, occurring at either a $\mathrm{S}$ or $\mathrm{N}$ of the pyridinethiolate ligand. The calculated $\mathrm{p} K_{\mathrm{a}}$ 's are 7.6 for sulfur protonation and 16.3 for nitrogen protonation, indicating that with experimental conditions at $\mathrm{pH} 7$ both of these sites can be protonated. The intermediate protonated at a nitrogen is more thermodynamically favored with a $\Delta \mathrm{G}$ at $\mathrm{pH} 7 \mathrm{of}-12.7 \mathrm{kcal} / \mathrm{mol}$ compared to the $\Delta \mathrm{G}$ for protonation at a ligand sulfur atom of only $-1 \mathrm{kcal} / \mathrm{mol}$.

Following initial protonation, $\mathrm{Ni}\left(6-\mathrm{CH}_{3} \mathrm{PyS}\right){ }_{3} \mathrm{H}_{\mathrm{N}}\{\mathrm{t}\}$ can either undergo a second protonation at a $\mathrm{S}, \mathrm{N}$ or $\mathrm{Ni}$, or be reduced to either $\mathrm{Ni}\left(6-\mathrm{CH}_{3} \mathrm{PyS}\right)_{3} \mathrm{H}^{-}\{\mathrm{d}\}$ or $\mathrm{Ni}(6-$ $\left.\mathrm{CH}_{3} \mathrm{PyS}\right)_{3} \mathrm{H}^{-}\{\mathrm{q}\}$. Protonation at $\mathrm{S}$ and $\mathrm{Ni}$ have respective $\mathrm{p} K_{a}$ 's of 1.0 and -2.6 , as such, neither species will be present at $\mathrm{pH}$ 7. However, dechelation and protonation of a second ligand nitrogen corresponds to a $\mathrm{p} K_{a}$ of $10.44(\Delta \mathrm{G}=-4.7 \mathrm{kcal} / \mathrm{mol}$ at $\mathrm{pH} 7)$ (Figure 4-2). The experimentally measured $\mathrm{p} K_{a}$ for $\mathrm{Ni}\left(6-\mathrm{CH}_{3} \mathrm{PyS}\right)_{3}{ }^{-}$is 10.7 , suggesting that proceeding through a doubly protonated intermediate could be a viable pathway. Due to the method by which we determined $\mathrm{p} K_{a}$ 's experimentally, without the application of an externally applied potential, the measured $\mathrm{p} K_{a}$ of 10.7 must necessarily correspond to a step that 
occurs prior to reduction. We propose that two sequential protonation events start the catalytic cycle, given experimentally determined $\mathrm{p} K_{a}$.

After undergoing two protonations, $\mathrm{Ni}\left(6-\mathrm{CH}_{3} \mathrm{PyS}\right){ }_{3} \mathrm{H}_{\mathrm{N}} \mathrm{H}_{\mathrm{N}}{ }^{+}\{\mathrm{t}\}$ can be reduced to $\mathrm{Ni}\left(6-\mathrm{CH}_{3} \mathrm{PyS}\right)_{3} \mathrm{H}_{\mathrm{N}} \mathrm{H}_{\mathrm{N}}\{\mathrm{d}\}$ or $\mathrm{Ni}\left(6-\mathrm{CH}_{3} \mathrm{PyS}\right)_{3} \mathrm{H}_{\mathrm{N}} \mathrm{H}_{\mathrm{N}}\{\mathrm{q}\}$. The double-state has electrons localized on the metal, while the quartet-state would have electrons localized on a ligand. $\mathrm{E}_{\text {calc }}^{0}$ for reduction to $\mathrm{Ni}\left(6-\mathrm{CH}_{3} \mathrm{PyS}\right)_{3} \mathrm{H}_{\mathrm{N}} \mathrm{H}_{\mathrm{N}}\{\mathrm{d}\}$ is $-0.89 \mathrm{~V}$, while $\mathrm{E}^{0}$ to $\mathrm{Ni}(6-$ $\left.\mathrm{CH}_{3} \mathrm{PyS}\right)_{3} \mathrm{H}_{\mathrm{N}} \mathrm{H}_{\mathrm{N}}\{\mathrm{q}\}$ is $-2.16 \mathrm{~V}$. Experimentally, the measured reduction potential is -1.09 $\mathrm{V}$ vs SCE. Thus, reduction to the doublet-state, with the electrons on the metal center, is preferred. From $\mathrm{Ni}\left(6-\mathrm{CH}_{3} \mathrm{PyS}\right)_{3} \mathrm{H}_{\mathrm{N}} \mathrm{H}_{\mathrm{N}}\{\mathrm{d}\}$, the necessary second reduction to yield $\mathrm{Ni}(6-$ $\left.\mathrm{CH}_{3} \mathrm{PyS}\right)_{3} \mathrm{H}_{\mathrm{N}} \mathrm{H}_{\mathrm{N}}{ }^{-}\{\mathrm{s}\} \quad$ or $\quad \mathrm{Ni}\left(6-\mathrm{CH}_{3} \mathrm{PyS}\right)_{3} \mathrm{H}_{\mathrm{N}} \mathrm{H}_{\mathrm{N}}{ }^{-}\{\mathrm{t}\} \quad$ requires $\quad-2.80 \mathrm{~V}$ and $-2.58 \mathrm{~V}$, respectively, making both reductions too energetically demanding to occur under the electrochemical hydrogen production conditions used herein (Figure 4-3). This suggests that hydrogen production is occurring through reduction a different intermediate. 


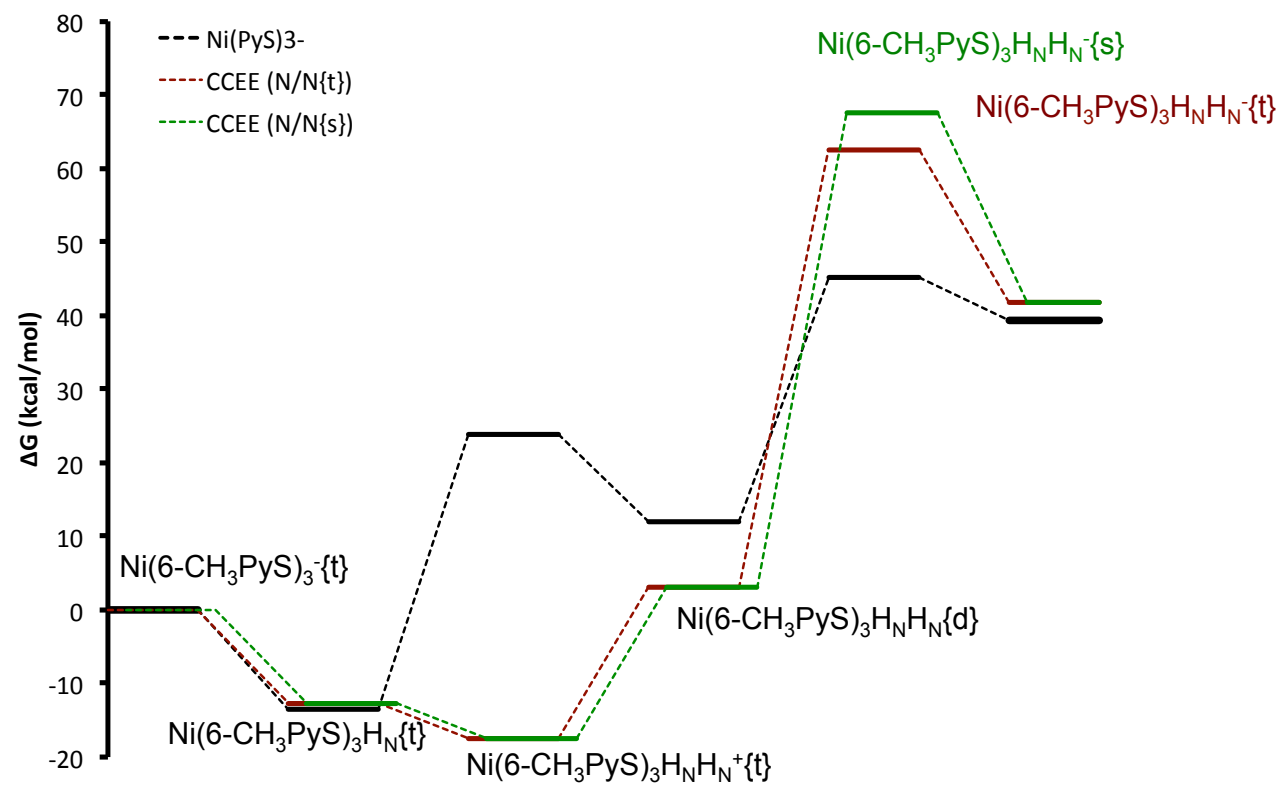

Figure 4-3: Reaction coordinate diagram showing prohibitively large $\Delta \mathrm{G}$ required to go from $\mathrm{Ni}\left(6-\mathrm{CH}_{3} \mathrm{PyS}\right)_{3} \mathrm{H}_{\mathrm{N}} \mathrm{H}_{\mathrm{N}}\{\mathrm{d}\}$ to $\mathrm{Ni}\left(6-\mathrm{CH}_{3} \mathrm{PyS}\right)_{3} \mathrm{H}_{\mathrm{N}} \mathrm{H}_{\mathrm{N}}{ }^{-}\{\mathrm{s}\}$ and $\mathrm{Ni}\left(6-\mathrm{CH}_{3} \mathrm{PyS}\right)_{3} \mathrm{H}_{\mathrm{N}} \mathrm{H}_{\mathrm{N}}{ }^{-}\{\mathrm{t}\}$.

An intermediate with a proton on the nickel center, $\mathrm{Ni}\left(6-\mathrm{CH}_{3} \mathrm{PyS}\right)_{3} \mathrm{H}_{\mathrm{N}} \mathrm{H}_{\mathrm{Ni}}\{\mathrm{d}\}$ has a calculated reduction potential of $-1.18 \mathrm{~V}$ vs SCE, which is in agreement with the experimentally determined potential of $-1.09 \mathrm{~V}$ vs SCE. Although direct protonation of the metal center is not favored ( $\mathrm{p} K_{a}$ of -2.6 ), proton shifts have been previously reported in proton reduction catalytic cycles; from pendant amines to nickel centers in NiP2N2 type catalysts. ${ }^{190}$ We propose that an internal proton shift occurs from a protonated ligand nitrogen to the metal center for $\mathrm{Ni}\left(6-\mathrm{CH}_{3} \mathrm{PyS}\right)_{3}^{-}$. This shift requires $21 \mathrm{kcal} / \mathrm{mol}$, and leads to the formation of $\mathrm{Ni}\left(6-\mathrm{CH}_{3} \mathrm{PyS}\right)_{3} \mathrm{H}_{\mathrm{N}} \mathrm{H}_{\mathrm{Ni}}\{\mathrm{d}\}$. The transition state corresponding to this movement of the proton from the ligand to the metal center was optimized and can be 
seen on the reaction coordinate diagram the transition from $\mathrm{Ni}\left(6-\mathrm{CH}_{3} \mathrm{PyS}\right){ }_{3} \mathrm{H}_{\mathrm{N}} \mathrm{H}_{\mathrm{N}}\{\mathrm{d}\}$ to $\mathrm{Ni}\left(6-\mathrm{CH}_{3} \mathrm{PyS}\right){ }_{3} \mathrm{H}_{\mathrm{N}} \mathrm{H}_{\mathrm{Ni}}\{\mathrm{d}\}$ in Figure 4-4.

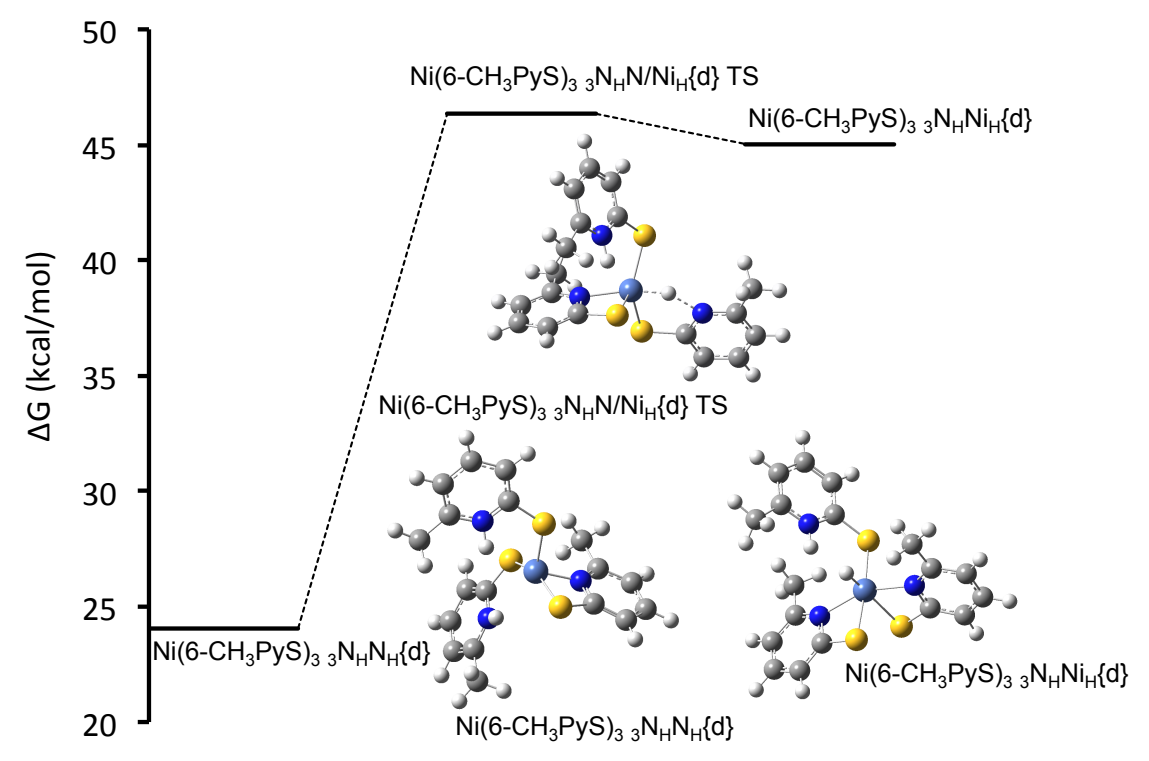

Figure 4-4: Reaction coordinate showing transition state between $\mathrm{Ni}(6-$ $\left.\mathrm{CH}_{3} \mathrm{PyS}\right)_{3} \mathrm{~N}_{\mathrm{H}} \mathrm{N}_{\mathrm{H}}\{\mathrm{d}\}$ and $\mathrm{Ni}\left(6-\mathrm{CH}_{3} \mathrm{PyS}\right)_{3} \mathrm{~N}_{\mathrm{H}} \mathrm{Ni}_{\mathrm{H}}\{\mathrm{d}\}$. Bond lengths between N-H and Ni-H for the transition state are $1.66 \AA$ and $1.50 \AA$, respectively.

In order to circumvent the large energetic requirement, we propose the proton shift and reduction occur simultaneously. Without computationally generated kinetic data we must rely on electrochemical data to support this claim. Reduction potentials are shifted negatively by approximately $10 \mathrm{mV}$ in deuterated solvent vs protonated solvent, suggesting PCET is occurring (Appendix Figure 8). This mechanism accounts for both the experimentally measured $\mathrm{p} K_{a}$ and reduction potential and helps to explain why $\mathrm{Ni}(6-$ $\left.\mathrm{CH}_{3} \mathrm{PyS}\right)_{3}{ }^{-}$ultimately has the lowest overpotential and highest TOF of the derivatives that were studied. $\mathrm{Ni}\left(6-\mathrm{CH}_{3} \mathrm{PyS}\right)_{3}{ }^{-}$can be readily protonated twice at $\mathrm{pH} 7$ and subsequently 
be reduced at lower potentials than the other derivatives. The CCEE mechanism of Ni(6$\left.\mathrm{CH}_{3} \mathrm{PyS}\right)_{3}{ }^{-}$contains the smallest energy fluctuations of all of the hydrogen production pathways considered (Figure 4-5).

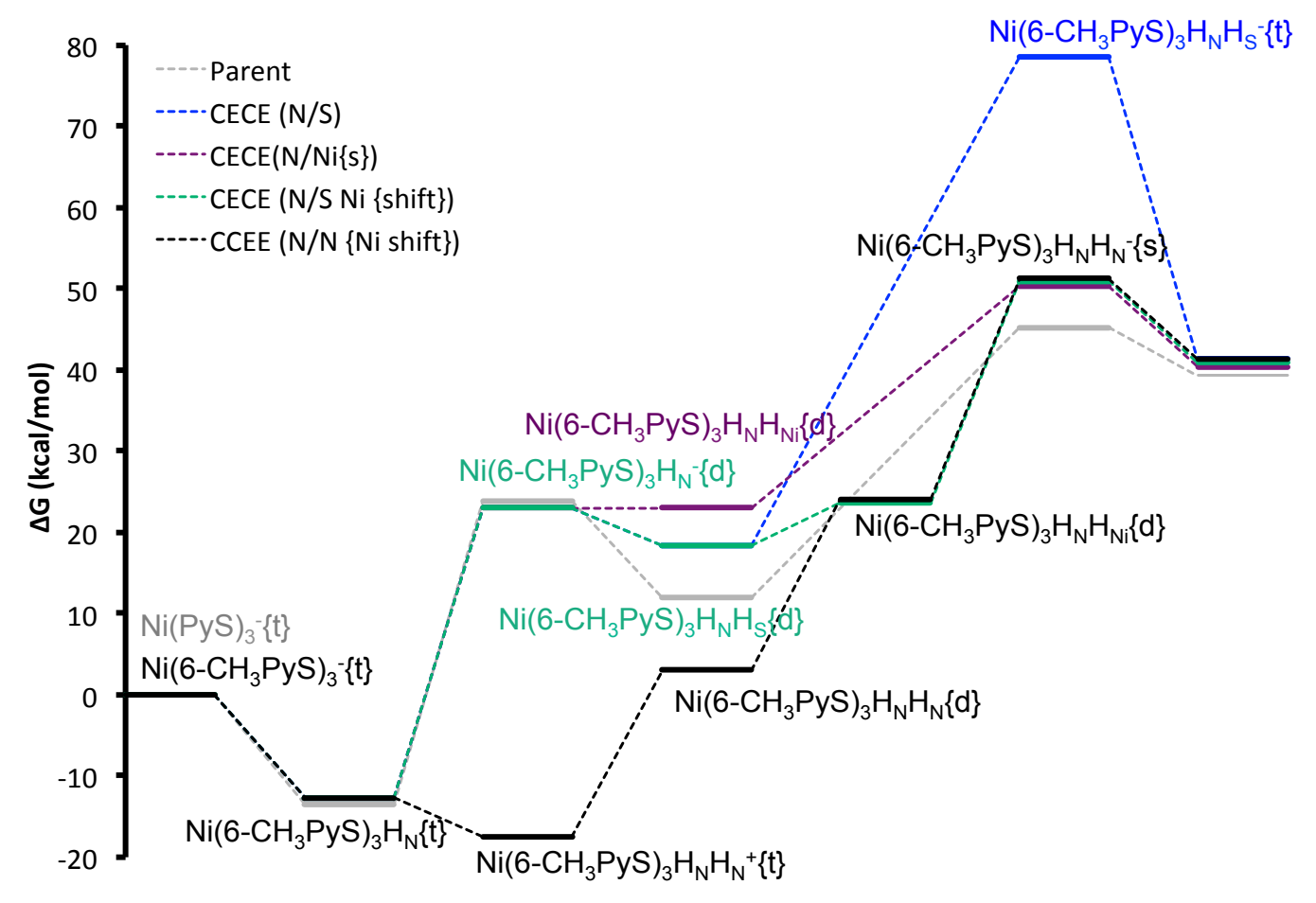

Figure 4-5: Reaction coordinate diagram comparing the four most likely pathways for $\mathrm{Ni}\left(6-\mathrm{CH}_{3} \mathrm{PyS}\right)_{3}{ }^{-}$catalyzed proton reduction. Thermodynamic values given for a solution of $\mathrm{pH} 7$ with no applied potential.

One final point of consideration for $\mathrm{Ni}\left(6-\mathrm{CH}_{3} \mathrm{PyS}\right)_{3}{ }^{-}$is the position of the electron-donating group on the pyridyl ring. The electron-donating group is in the ortho position relative to the nitrogen, while electron withdrawing substitutions we studied are in the meta positions for compounds $\mathrm{Ni}\left(3-\mathrm{CF}_{3} \mathrm{PyS}\right)_{3}{ }^{-} \mathrm{Ni}(5-\mathrm{ClPyS})_{3}{ }^{-}$; these derivatives were chosen due to commercial availability of the ligands. In order to ensure that steric 
effects are not responsible for the unique mechanism of this catalyst, analogous computations were performed with the donating group at the meta and para position relative to the pyridyl nitrogen, to minimize steric hindrance. The corresponding $\mathrm{p} K_{a}$ 's for the protonated meta and para substituted derivatives are 14.6 and 15.1, respectively compared to 16.3 for $\mathrm{Ni}\left(6-\mathrm{CH}_{3} \mathrm{PyS}\right)_{3}{ }^{-}$. Though there is an effect on $\mathrm{p} K_{a}$ as a result of substitution position, all three of these compounds are still significantly more basic than compounds $\mathrm{Ni}\left(3-\mathrm{CF}_{3} \mathrm{PyS}\right)_{3}{ }^{-}-\mathrm{Ni}(5-\mathrm{ClPyS})_{3}{ }^{-}$, whose $\mathrm{p} K_{a}$ 's range from 6.3 to 7.8 . Subsequent protonation required for the CCEE mechanism is possible again for both isomers at $\mathrm{pH} 7\left(\mathrm{p} K_{a \text { para }}=9.3\right.$ and $\left.\mathrm{p} K_{a \text { meta }}=7.1\right)$. The remaining two electrical steps occur for the meta isomer at $-0.95 \mathrm{~V}$ vs SCE and $-1.10 \mathrm{~V}$ vs SCE, and at $-1.04 \mathrm{~V}$ vs SCE and $-1.10 \mathrm{~V}$ vs SCE for the para isomer (Table S1). These values are similar to those calculated for $\mathrm{Ni}\left(6-\mathrm{CH}_{3} \mathrm{PyS}\right)_{3}{ }^{-}$ortho of $-0.89 \mathrm{~V}$ vs SCE and $-1.18 \mathrm{~V}$ vs SCE. Finally, the energetic requirement for the proton shift from the pyridyl $\mathrm{N}$ to the Ni center for both of these isomers are within $1 \mathrm{kcal} / \mathrm{mol}$ of the $21 \mathrm{kcal} / \mathrm{mol}$ requirement for $\mathrm{Ni}\left(6-\mathrm{CH}_{3} \mathrm{PyS}\right)_{3}{ }^{-}$. Thus, regardless of the position of the electron donating substituent, its impact on the catalytic mechanism is maintained. 
Table 4-3: Second $\mathrm{p} K_{a}$ (with location of protonation) and second reduction potential (V vs SCE)

\begin{tabular}{|c|c|c|}
\hline Ligand & $\mathrm{p} K_{a \text { (calc) }}(2)$ & $\mathbf{E}_{\text {(calc) }}^{0}(2)$ \\
\hline$\left(3-\mathrm{CF}_{3} \overline{\mathrm{PyS}}\right)$ & $2.35(\mathrm{Ni})$ & -0.96 \\
\hline$\left(5-C_{3} P y S\right)$ & $2.38(\mathrm{Ni})$ & -1.04 \\
\hline (6-S-3-COOHPyS) & $-1.80(\mathrm{Ni})$ & -0.88 \\
\hline (2-S-3-COOHPyS) & $9.23(\mathrm{Ni})$ & -0.94 \\
\hline (5-CIPyS) & $8.86(\mathrm{Ni})$ & -1.38 \\
\hline$\left(6-\mathrm{CH}_{3} \mathrm{PyS}\right)$ & $10.44(\mathrm{~N})$ & -1.18 \\
\hline
\end{tabular}

However, for electron-withdrawing $-\mathrm{COOH}$ substitutions the position has a significant effect on the $\mathrm{p} K_{\mathrm{a}}$ of the third intermediate. For compounds $\mathrm{Ni}(6-\mathrm{S}-3-\mathrm{COOH})_{3}{ }^{-}$ and $\mathrm{Ni}(2-\mathrm{S}-3-\mathrm{COOH})_{3}{ }^{-}$, which contain $-\mathrm{COOH}$ in para and ortho positions, respectively relative to the sulfur, $\mathrm{Ni}(6-\mathrm{S}-3-\mathrm{COOH})_{3}{ }^{-}$has a $\mathrm{p} K_{a}$ of -1.80 and $\mathrm{Ni}(2-\mathrm{S}-3-\mathrm{COOH})_{3}{ }^{-}$has a $\mathrm{p} K_{a}$ of 9.23 (Table 4-3). We suspect the difference in acidity for these two compounds is a result of the proximity of the ortho $-\mathrm{COOH}$ substituent to the metal center which can stabilize the protonated state by acting as an intra-molecular proton shuttle. Work studying the effects of pendant amines on $\mathrm{Ni}$ containing catalysts has shown that pendant ligands, when in the vicinity of the metal center, can have stabilizing effects on critical reaction intermediates such as hydrogen and hydride containing complexes. ${ }^{79,191-193}$ This leads to significant increases in the $\mathrm{p} K_{a}$ for stabilized intermediates. An increase in basicity of $8 \mathrm{p} K_{a}$ units has been reported for isomers of a hydrogenase models that 
contain amine/metal center interactions. ${ }^{32}$ This same effect of position on $\mathrm{p} K_{a}$ is not observed when comparing the $-\mathrm{CF}_{3}$ derivatives, $\mathrm{Ni}\left(3-\mathrm{CF}_{3} \mathrm{PyS}\right)_{3}{ }^{-}$and $\mathrm{Ni}\left(5-\mathrm{CF}_{3} \mathrm{PyS}\right)_{3}{ }^{-}$that have very similar $\mathrm{p} K_{a}$ values of 2.35 and 2.38 respectively.

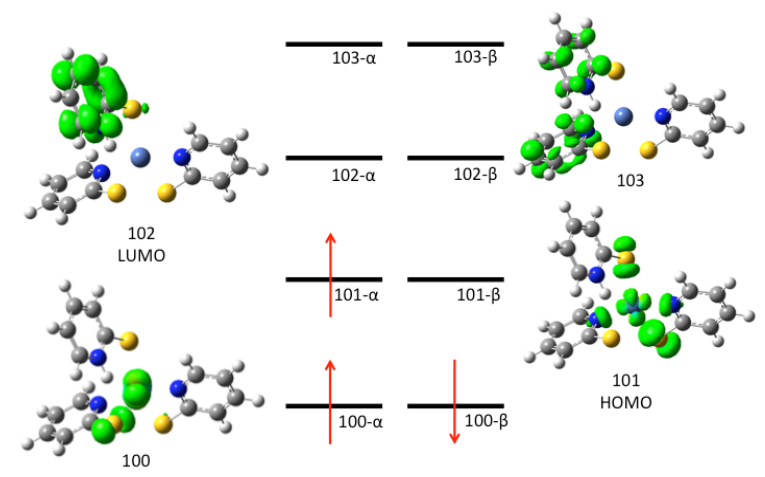

Figure 4-6: $\mathrm{MO}$ diagram for $\mathrm{Ni}(\mathrm{PyS})_{3} \mathrm{H}^{-}$for orbitals $100-103$ showing $\alpha$-orbitals 101 with contributions from both sulfur p-orbitals as well as nickel d-orbitals.

Ligand involvement is not restricted to protonation events. Non-innocent ligands can also influence reduction. In the CECE mechanism, the compound is reduced after the first protonation. Our intuition suggests reduction of compounds with decreased electron density may be ligand centered rather than metal centered. The first reduction in the catalytic cycle brings the compound back to an overall -1 charge and could result in a doublet-spin-state if reduction occurs at the metal center, or a quartet-spin-state, for which electron density is distributed on the protonated ligand. The parent compound, $\mathrm{Ni}(\mathrm{PyS})_{3} \mathrm{H}$, was determined to undergo reduction to a low spin, doublet state, where the incoming electron is localized on a d-orbital at the nickel center (Figure 4-6). The LUMO (designated as $100 \beta$-orbital) is the logical recipient for this first electron (Figure 4-7). 
From visual inspection of this unoccupied frontier molecular orbital, it is apparent that a portion of the orbital is indeed the result of contributions from d-orbitals of the nickel center. Furthermore, calculated values of $\mathrm{E}^{0}$ are systematically higher for reduction to the quartet-spin-state, resulting from reduction of the ligand, than for the metal-centered reduction to the doublet-state.

A second protonation and reduction must occur to produce hydrogen. For all compounds, except $\mathrm{Ni}(5-\mathrm{ClPyS})_{3}{ }^{-}$and $\mathrm{Ni}\left(6-\mathrm{CH}_{3} \mathrm{PyS}\right)_{3}{ }^{-}$, the first calculated reduction potential corresponds to the experimentally measured $\mathrm{E}^{0}$ value. Reduction of $\mathrm{Ni}(5-$ $\mathrm{ClPyS})_{3}{ }^{-}$was calculated at $-1.38 \mathrm{~V}$ for both the first and second reduction, making it impossible to distinguish which event is being measured experimentally. In our initial computational investigation of $\mathrm{Ni}(\mathrm{PyS})_{3}{ }^{-}$catalyzed proton-reduction, the second

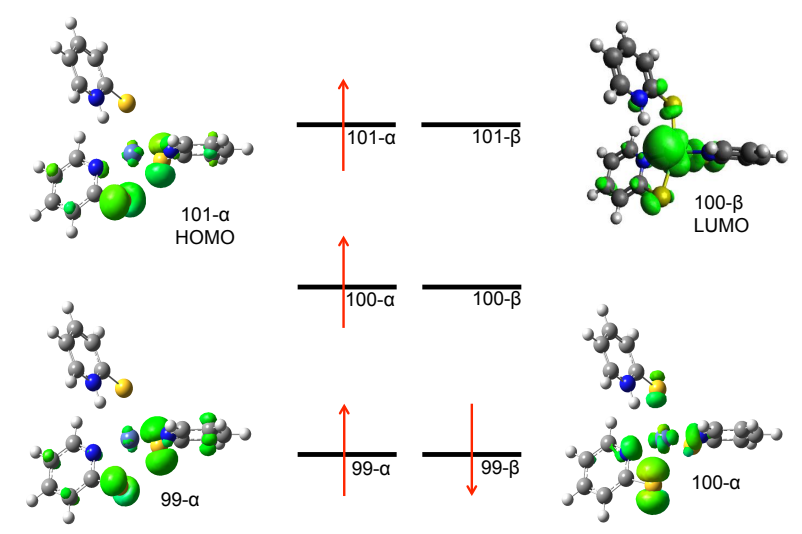

Figure 4-7: $\mathrm{MO}$ diagrams from $\mathrm{Ni}(\mathrm{PyS})_{3} \mathrm{H}$ for orbitals 99, 100 and 101, showing that the LUMO, 100- $\beta$, is localized at the nickel center, which would lead to a low spin configuration of $\mathrm{Ni}(\mathrm{PyS})_{3} \mathrm{H}^{-}$following reduction. 
reduction is attributed to formation of a Ni-hydride through PCET. ${ }^{188}$

The CECE pathway was modeled with placement of the second proton on the nickel center. The $\mathrm{p} K_{a}$ 's for these species can be seen in Table 3. For $\mathrm{Ni}\left(3-\mathrm{CF}_{3} \mathrm{PyS}\right)_{3}{ }^{-}$, $\mathrm{Ni}\left(5-\mathrm{CF}_{3} \mathrm{PyS}\right)_{3}{ }^{-}$and $\mathrm{Ni}(6-\mathrm{S}-3-\mathrm{COOH})_{3}{ }^{-}$highly acidic compounds result, indicating that for these derivatives this chemical step may be occurring via PCET to yield a hydride intermediate, as was the case for $\mathrm{Ni}(\mathrm{PyS})_{3}{ }^{-}$. It has been noted previously that when highenergy intermediates result from proton transfer steps, the energetic barrier can be

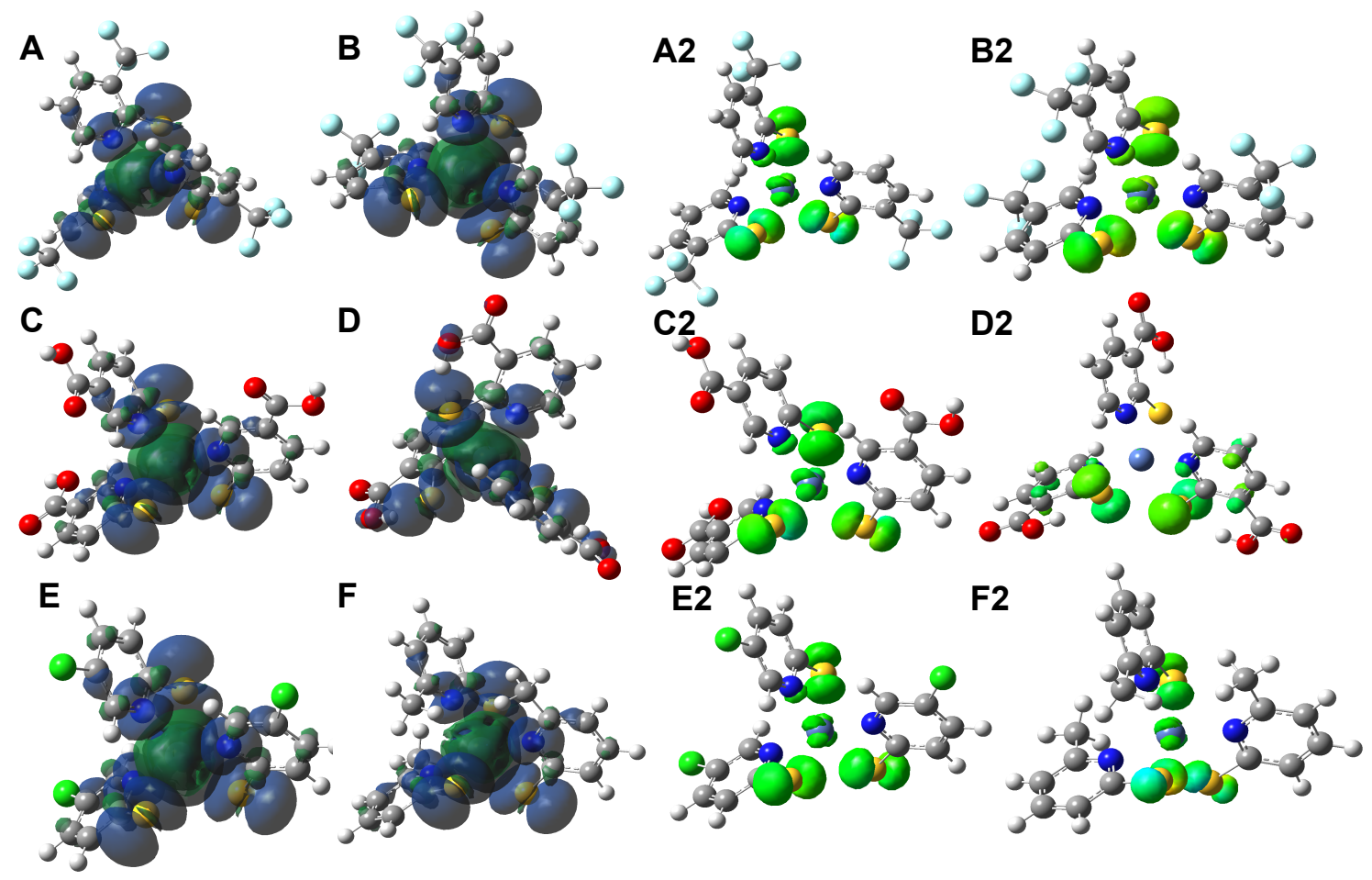

Figure 4-8: A-F mapped SOMO's for derivatives demonstrating primary contribution from $\mathrm{S}$ p-orbitals. A2-F2 spin density maps for $\mathrm{Ni}(\mathrm{PyS})_{3}{ }^{-}$derivatives showing location of unpaired electron density. Atoms: white, hydrogen; grey, carbon; light blue, fluorine; dark blue, nitrogen; red, oxygen; yellow, sulfur; green, chlorine. A) $\left.\mathrm{Ni}\left(3-\mathrm{CF}_{3} \mathrm{PyS}\right)_{3}{ }^{-} \mathrm{B}\right)$ $\left.\left.\left.\left.\mathrm{Ni}\left(5-\mathrm{CF}_{3} \mathrm{PyS}\right)_{3}{ }_{3}^{-} \mathrm{C}\right) \mathrm{Ni}(6-\mathrm{S}-3-\mathrm{COOHPyS})_{3}{ }^{-} \mathrm{D}\right) \mathrm{Ni}(2-\mathrm{S}-3-\mathrm{COOHPyS})_{3}{ }^{-} \mathrm{E}\right) \mathrm{Ni}(5-\mathrm{ClPyS})_{3}{ }_{3}^{-} \mathrm{F}\right)$ $\mathrm{Ni}\left(6-\mathrm{CH}_{3} \mathrm{PyS}\right)_{3}{ }^{-}$ 
bypassed by concerted addition of a proton and an electron simultaneously. ${ }^{79}$ Computational investigation of PCET steps were not considered in this study. Rather we look at the second protonation and reduction as two separate steps to distinguish the thermodynamic requirements of each.

Thus, the final step is a reduction, which brings all compounds back to an overall -1 charge and results in formation of an intermediate that can exist as either a triplet or a singlet-spin-state. A singlet-state would require the electron to be localized on the metal center, while a triplet-spin-state could be a result of electron density located on either the $\mathrm{H}$ atom or a PyS ligand. Spin density maps of the unpaired electron density supports formation of a hydride (Figure 4-8). The triplet-states for most of the compounds are lower in energy than their singlet-state analogues. The triplet-state of $\mathrm{Ni}\left(5-\mathrm{CF}_{3} \mathrm{PyS}\right)_{3}{ }^{-}$is

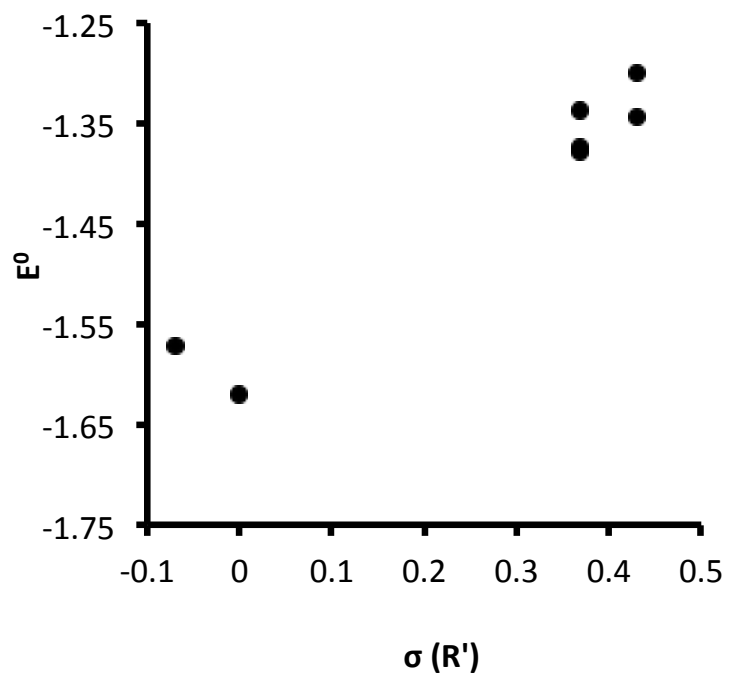

Figure 4-9: Relationship between $\mathrm{E}^{0}$ from computed data and Hammett constants. 
slightly higher in energy than the singlet-state, however, the singlet-state intermediate has complete dechelation of the protonated ligand. Furthermore, the proton and hydride are not spatially oriented for elimination of hydrogen in the singlet-state-intermediate, thus we suggest that the triplet-state-intermediate is still part of the reaction pathway.

The meridional geometry for these complexes results in two unique chemical environments for the pyridyl nitrogen. Thus the second protonation of $\mathrm{Ni}\left(6-\mathrm{CH}_{3} \mathrm{PyS}\right)_{3}{ }^{-}$ could occur at the nitrogen atom either trans or cis to the protonated nitrogen. The protonation of the nitrogen atom located cis to the already protonated nitrogen was discussed above. Protonating in the trans geometry results in a $\mathrm{pK}_{\mathrm{a}}$ of 26.9 , which is likely stabilized by hydrogen-bonding interactions with the nearby sulfur atom. However, because the $\mathrm{p} K_{a}$ value is not directly supported with experimental data, it was not highlighted alongside the described CCEE mechanism above, though it is a possible intermediate given the experimental conditions used. Optimized structures of both of these doubly protonated compounds can be seen in Appendix Figure 11. The CCEE mechanism for the derivatives of $\mathrm{Ni}(\mathrm{PyS})_{3}{ }^{-}$without electron-rich substituents was also investigated (Appendix Figure 11). Several isomers exist for each compound and both protonation sites are unique, with different $\mathrm{p} K_{a}$ values. For example, for $\mathrm{Ni}\left(3-\mathrm{CF}_{3} \mathrm{PyS}\right)_{3}{ }^{-}$ the trans protonation site has a $\mathrm{p} K_{a}$ of 4.6 while the cis position has a $\mathrm{p} K_{a}$ of 6.0 . Computational results alone suggest that in some instances, a second protonation may be possible, but due to a lack of experimental agreement including subsequent reduction potentials this pathway was not considered further. 
The relationship between initial $\mathrm{p} K_{a}$, initial $\mathrm{E}^{0}$ and Hammett constant is consistent with the literature. ${ }^{182}$ As substituents become more electron withdrawing, $\mathrm{E}^{0}$ decreases in magnitude, a desirable result to decrease required overpotentials (Figure 4-9). The reverse relationship is observed between $\mathrm{pK}_{\mathrm{a}}$ values and Hammett constant. As electronwithdrawing capability increases, $\mathrm{pK}_{\mathrm{a}}$ decreases, limiting the range of $\mathrm{pH}$ 's at which the protonated species can exist and begin the catalytic cycle. Consequently, $\mathrm{pK}_{\mathrm{a}}$ and $\mathrm{E}^{0}$ are inversely affected by substitution. This inverse relationship makes it difficult to optimize both the $\mathrm{p} K_{a}$ and reduction potential using simple ligand substitution. However, as shown in the discussion of $\mathrm{Ni}\left(6-\mathrm{CH}_{3} \mathrm{PyS}\right)_{3}{ }^{-}$, changes in the mechanism that result from ligand modification can supersede this relationship. Furthermore, this is observed in the influence of ligand modification on the experimentally measured electrochemical TOF.

Catalytic efficiency was quantified through TOFs, which were determined electrochemically ${ }^{86,194-197}$ It appears that the most electron withdrawing substitutions negatively impact the rate of hydrogen production, as seen in Table 4-2 where compounds $\mathrm{Ni}\left(3-\mathrm{CF}_{3} \mathrm{PyS}\right)_{3}{ }^{-}$and $\mathrm{Ni}\left(5-\mathrm{CF}_{3} \mathrm{PyS}\right)_{3}{ }^{-}$have lowest experimentally measured TOF's. The two carboxylic acid containing catalysts, $\mathrm{Ni}(6-\mathrm{S}-3-\mathrm{COOH})_{3}{ }^{-}$and $\mathrm{Ni}(2-\mathrm{S}-3-$ $\mathrm{COOH})_{3}{ }^{-}$, show a mild increase in TOF relative to $\mathrm{Ni}\left(3-\mathrm{CF}_{3} \mathrm{PyS}\right)_{3}{ }^{-}$and $\mathrm{Ni}\left(5-\mathrm{CF}_{3} \mathrm{PyS}\right)_{3}{ }^{-}$. Although $\mathrm{Ni}(5-\mathrm{ClPyS})_{3}{ }^{-}$is substituted with $-\mathrm{Cl}$ groups that have the same Hammettconstant as the $-\mathrm{COOH}$ groups, it has a TOF that is nearly double, $314 \mathrm{~s}^{-1}$ for $\mathrm{Ni}(5-$ $\mathrm{ClPyS}_{3}{ }^{-}$compared to $164 \mathrm{~s}^{-1}$ for $\mathrm{Ni}(6-\mathrm{S}-3-\mathrm{COOH})_{3}{ }^{-}$and $\mathrm{Ni}(2-\mathrm{S}-3-\mathrm{COOH})_{3}{ }^{-}$. The TOF of $\mathrm{Ni}(5-\mathrm{ClPyS})_{3}{ }^{-}$is quite similar to that of $\mathrm{Ni}\left(6-\mathrm{CH}_{3} \mathrm{PyS}\right)_{3}{ }^{-}\left(332 \mathrm{~s}^{-1}\right)$, which has the most 
electron rich ligands. The effect of these substituents on the rate of hydrogen production warrants further investigation.

\subsection{Conclusions}

Through the joint use of computational and experimental means, six derivatives of $\mathrm{Ni}(\mathrm{PyS})_{3}{ }^{-}$were studied to evaluate the effect of ligand modification on properties of the catalysts and their hydrogen production mechanisms. Compounds containing electron poor ligands maintain the CECE mechanism followed by the parent compound. The TOF's of these derivatives are limited by the initial metal-centered reduction event, which occurs at a greater potential than the second reduction. $\mathrm{E}^{0}$ and $\mathrm{p} K_{a}$ for the first two steps of these catalytic cycles show linear correlation with Hammett-constants and the relationship between these two parameters is inversely favorable. The electron rich ligand has the most substantial impact on the mechanism of hydrogen production, causing deviation from a CECE mechanism in favor of a CCEE mechanism, which involves a proton shift from a pyridyl nitrogen to the nickel center following the second protonation. 
CHAPTER 5

\section{HETEROLEPTIC MODIFICATION OF NICKEL PYRIDINETHIOLATE Unexpected structural effects of heteroleptic catalyst design}

\subsection{Introduction}

Unpublished work.

Rational design of transition metal catalysts has been pursued for decades as a way of methodically creating new compounds for the conversion of solar energy into chemical fuel. ${ }^{56,179}$ The computational study of transition metal electrocatalysts for water splitting is one such area that has received great attention in recent years. ${ }^{77,163,164,198-200}$ However, the purely theoretical assessment of target catalysts remains slightly out of reach, and thus a joint theoretical and experimental approach currently provides an accessible means of studying and improving complex catalytic systems. ${ }^{181,201}$ When applying theoretical and experimental methods to the study of proton reduction catalysts, such as $\mathrm{Ni}(\mathrm{PyS})_{3}{ }^{-}$and its derivatives, particular focus is given to the determination of $\mathrm{p} K_{a}$ values and $\mathrm{E}^{0}$ values, ${ }^{202}$ as these thermodynamic properties are indicators of how easily the catalyst will be protonated and reduced. ${ }^{121}$ By extension, this affects the $\mathrm{pH}$ at which hydrogen generation is possible, in addition to the required overpotential for proton reduction. Ideally, hydrogen production would occur at low overpotentials and in either neutral or basic solution, so as to be more easily coupled with the oxygen evolving half reaction of water splitting. ${ }^{203}$ Ligand modification is one way to design new proton 
reduction catalysts with these targeted properties, ${ }^{166,204,205}$ however unexpected outcomes are possible due to the variety and complexity of catalytic pathways that can be accessed. $^{87,206,207}$

In Chapter 4 we presented a series of six derivatives of $\mathrm{Ni}(\mathrm{PyS})_{3}{ }^{-}$, made by uniform ligand modification to all three $\mathrm{PyS}^{-}$ligands, with either electron donating or withdrawing substituents (Figure 5-1). ${ }^{208}$ The original Ni(PyS $)_{3}{ }^{-}$catalyst was previously found to operate via a CECE (chemical-electrochemical-chemical-electrochemical) mechanism, where the initial protonation step occurs at a pyridyl nitrogen and the second protonation likely occurs through concerted PCET (proton-coupled electron transfer) to generate a nickel hydride. ${ }^{121}$ Due to agreement between the existing experimental data and our calculated results, this mechanism was chosen as the starting point for the study of the six $\mathrm{Ni}(\mathrm{PyS})_{3}{ }^{-}$derivatives. We found that electron-withdrawing substituents tend to

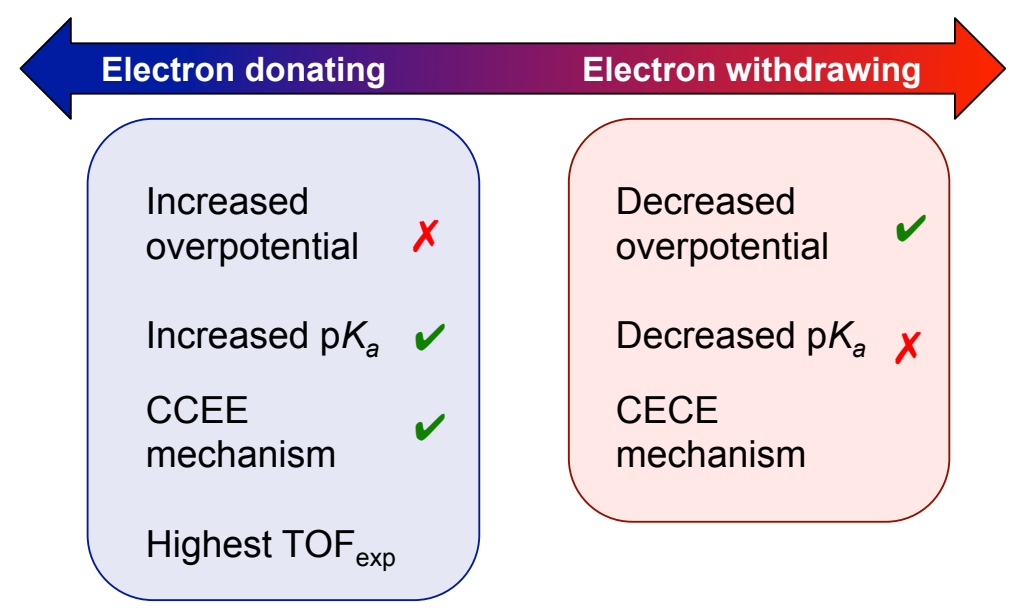

Figure 5-1: Influence of electron donating and electron withdrawing modifications on the properties and mechanisms of homoleptic $\mathrm{Ni}(\mathrm{PyS})_{3}{ }^{-}$derivatives. 
maintain the CECE mechanism, but result in low electrochemical hydrogen production rates. On the other hand, the most electron rich substituent $\left(-\mathrm{CH}_{3}\right)$ was found not only to correlate to a high rate of hydrogen production, but was also found to preferentially proceed through a CCEE mechanism. These results serve as an example of the complexity often encountered in the study of electrochemical hydrogen production by transition metal catalysts.

In the current study, the effect of non-uniform ligand modification was studied using the same joint theoretical and experimental method. A series of four heteroleptic compounds were chosen for study, using ligands $3-\mathrm{CF}_{3} \mathrm{PyS}^{-}$and $6-\mathrm{CH}_{3} \mathrm{PyS}^{-}$as the respective electron withdrawing and donating ligands (Figure 5-2). These are referred to as $\mathrm{Ni}\left(6-\mathrm{CH}_{3} \mathrm{PyS}\right)_{2}(\mathrm{PyS})^{-}, \quad \mathrm{Ni}(\mathrm{PyS})_{2}\left(6-\mathrm{CH}_{3} \mathrm{PyS}\right)^{-}, \quad \mathrm{Ni}(\mathrm{PyS})_{2}\left(3-\mathrm{CF}_{3} \mathrm{PyS}\right)^{-}$and $\mathrm{Ni}(3-$ $\left.\mathrm{CF}_{3} \mathrm{PyS}\right)_{2}(\mathrm{PyS})^{-}$(Figure 5-3). We hypothesize that it is possible choose ligand combinations to target the desired properties mentioned above for an ideal proton

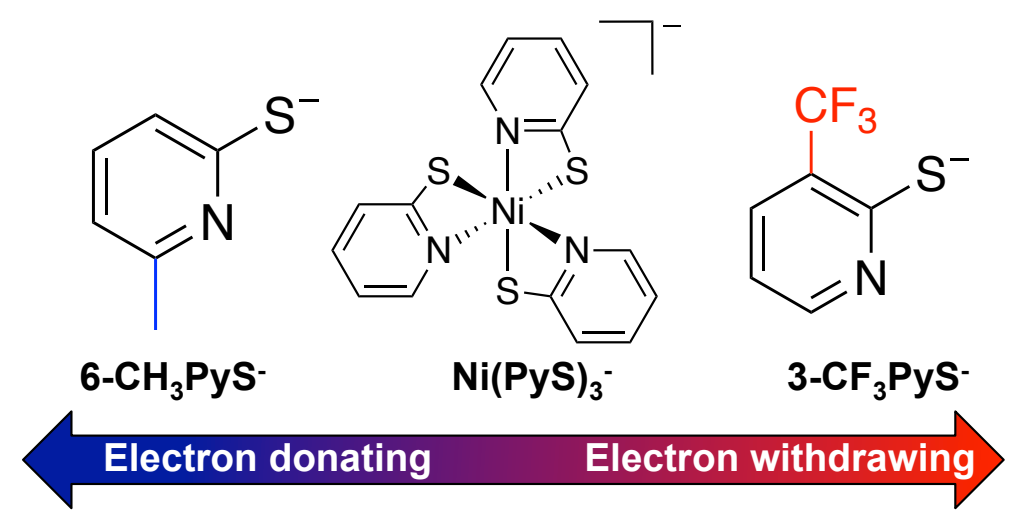

Figure 5-2: Electron rich $6-\mathrm{CH}_{3} \mathrm{PyS}^{-}$and electron poor $3-\mathrm{CF}_{3} \mathrm{PyS}^{-}$ligands chosen to make the heteroleptic compounds as well as the structure of the unmodified $\mathrm{Ni}(\mathrm{PyS})_{3}{ }^{-}$ catalyst. 
reduction catalyst, namely high $\mathrm{p} K_{a}$ and low $\mathrm{E}^{0}$ values. These predictions build off of the findings presented in Chapter 4 , where changes in $\mathrm{p} K_{a}$ and $\mathrm{E}^{0}$ were studied as a function of the electron donating or withdrawing nature of the selected ligands, quantified by their Hammet-constants. The more electron rich ligands were found to promote higher $\mathrm{p} K_{a}$ values, and the electron poor ligands were found to promote lower reduction potentials. This trend has been previously noted for catalysts such as $\mathrm{Co}(\mathrm{dmg})_{2}{ }^{182}$ Through the use of heteroleptic compounds, we attempt to tune these two physical properties independently of one another. Electron rich ligands are expected to provide a more electron rich site for protonation, thus allowing hydrogen production under more basic conditions, while electron poor ligands are expected to offset increased electron density at the metal center, thus facilitating reduction and resulting in lower overpotentials.

This type of heteroleptic nickel catalyst for proton reduction has, to our knowledge, never previously been reported. The results of this study demonstrate the subtle complexity of this class of compounds and how unanticipated structural effects lead to complex outcomes. Specifically, due to the geometry of these heteroleptic nickel

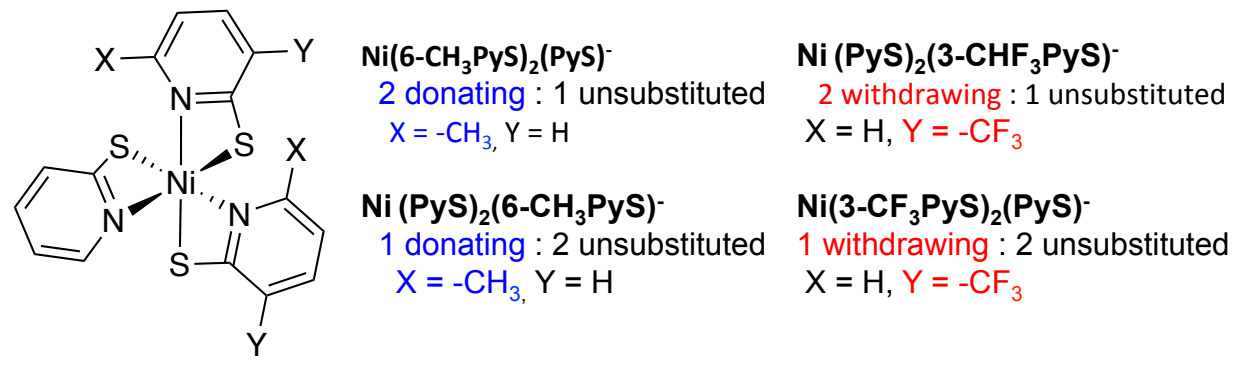

Figure 5-3: Scheme for the design of heteroleptic compounds. 
complexes, a variety of isomers exist for each compound that can have greatly differing physical properties. For example, for the same protonation step the $\mathrm{p} K_{a}$ can vary by as much as $6 \mathrm{p} K_{a}$ units. Ultimately, this leads to a large variety of possible hydrogen production mechanisms, even among isomers of the same heteroleptic compound. Because each catalyst has three starting isomers, after just the first protonation step it is possible to have nine different isomers for each compound, and that is only after consideration of the initial pronation step occurring at a pyridyl nitrogen. As such, one of the goals of this work is to use illustrative examples to highlight the most important outcomes of making and studying heteroleptic compounds as well as to propose a method for how to approach similar problems in the study of heteroleptic compounds for different applications.

\subsection{Results}

\subsubsection{Computational results}

Initial isomers of heteroleptic compounds

Heteroleptic compounds were designed to target both high $\mathrm{p} K_{a}$ values and low overpotentials. This is achieved by either substituting one or two ligands with an electron rich group, thereby increasing proton affinity, or by substituting one or two ligands with an electron withdrawing group to reduce the overpotential. To identify the unique effect of each type of substituent on the properties and effectiveness of heteroleptic compounds, we chose to study compounds using 2:1 and 1:2 ratios of substituted ligand to unsubstituted ligand (Figure 5-3). Due to the geometry of the bidentate ligands about the 


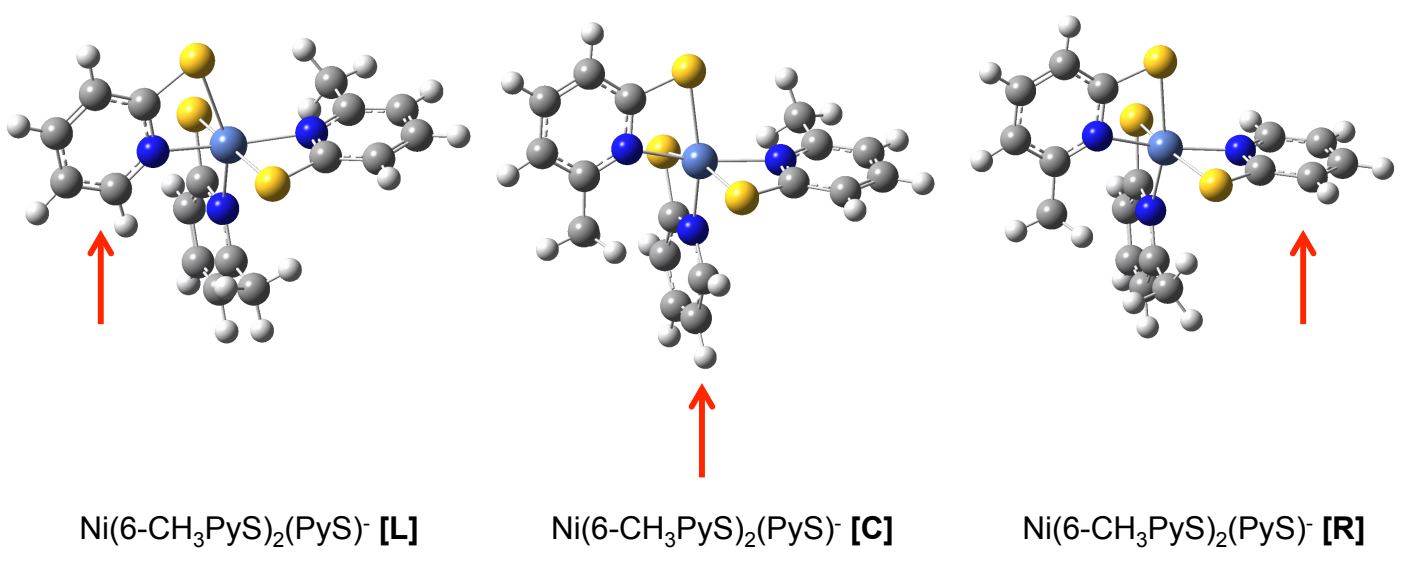

Figure 5-4: Naming scheme for the three isomers of $\mathrm{Ni}\left(6-\mathrm{CH}_{3} \mathrm{PyS}\right)_{2}(\mathrm{PyS})^{-}$. The naming scheme is used for all of the compounds when they are viewed with a vertical meridional plane with the sulfurs on top. The L, C and R distinctions designate the position of the one unique ligand.

nickel center, each heteroatom is in a unique chemical environment. This results in three possible isomers for each heteroleptic catalyst prior to the first step in the catalytic cycle. The geometry can best be observed when viewing the catalyst such that the meridional planes are vertical and the sulfurs are on top. When the three isomers are aligned in this way the one unique ligand will appear either to the right of the plane of sulfurs [R], in the plane (center) [C], or to the left of the plane [L] (Figure 5-4). The back sulfur must be connected to the ligand that lies in the same plane as the meridional sulfur atoms. We have established a naming scheme based on viewing the molecules in this way. For example, for $\mathrm{Ni}\left(6-\mathrm{CH}_{3} \mathrm{PyS}\right)_{2}(\mathrm{PyS})^{-}$, when the catalyst is viewed as shown in Figure 5-4, the compound is named $\mathrm{Ni}\left(6-\mathrm{CH}_{3} \mathrm{PyS}\right)_{2}(\mathrm{PyS})^{-}[\mathrm{C}]$ when the unique ligand is positioned centrally. When the unique ligand is on either the left or the right, the isomer is then called $\mathrm{Ni}\left(6-\mathrm{CH}_{3} \mathrm{PyS}\right)_{2}(\mathrm{PyS})^{-[\mathrm{L}]}$ or $\mathrm{Ni}\left(6-\mathrm{CH}_{3} \mathrm{PyS}\right)_{2}(\mathrm{PyS})^{-}[\mathrm{R}]$, respectively. Each of the 
three isomers is unique and has its own energy of formation as well as multiple values for $\mathrm{p} K_{a}$ and $\mathrm{E}^{0}$

The structures of all three isomers for each heteroleptic catalyst were optimized and the relative energies of the isomers were compared to determine the likelihood that they will be formed experimentally (Figure 5-5 and Table 5-1). The most electron rich catalyst $\mathrm{Ni}\left(6-\mathrm{CH}_{3} \mathrm{PyS}\right)_{2}(\mathrm{PyS})^{-}$is most stable in the $\mathrm{Ni}\left(6-\mathrm{CH}_{3} \mathrm{PyS}\right)_{2}(\mathrm{PyS})^{-}$[C] conformation, with the unsubstituted ligand in the central position. On the other hand, for the second electron rich catalyst, $\mathrm{Ni}(\mathrm{PyS})_{2}\left(6-\mathrm{CH}_{3} \mathrm{PyS}\right)^{-}$, the most stable conformation is $\mathrm{Ni}(\mathrm{PyS})_{2}\left(6-\mathrm{CH}_{3} \mathrm{PyS}\right)^{-}[\mathrm{L}]$, and the most unstable is $\mathrm{Ni}(\mathrm{PyS})_{2}\left(6-\mathrm{CH}_{3} \mathrm{PyS}\right)^{-}[\mathrm{C}]$, where the one unique ligand is centrally positioned. Interestingly, $\mathrm{Ni}(\mathrm{PyS})_{2}\left(6-\mathrm{CH}_{3} \mathrm{PyS}\right)^{-}[\mathrm{R}]$ is relatively low in energy, suggesting that placement of ligand $6-\mathrm{CH}_{3} \mathrm{PyS}^{-}$in the central
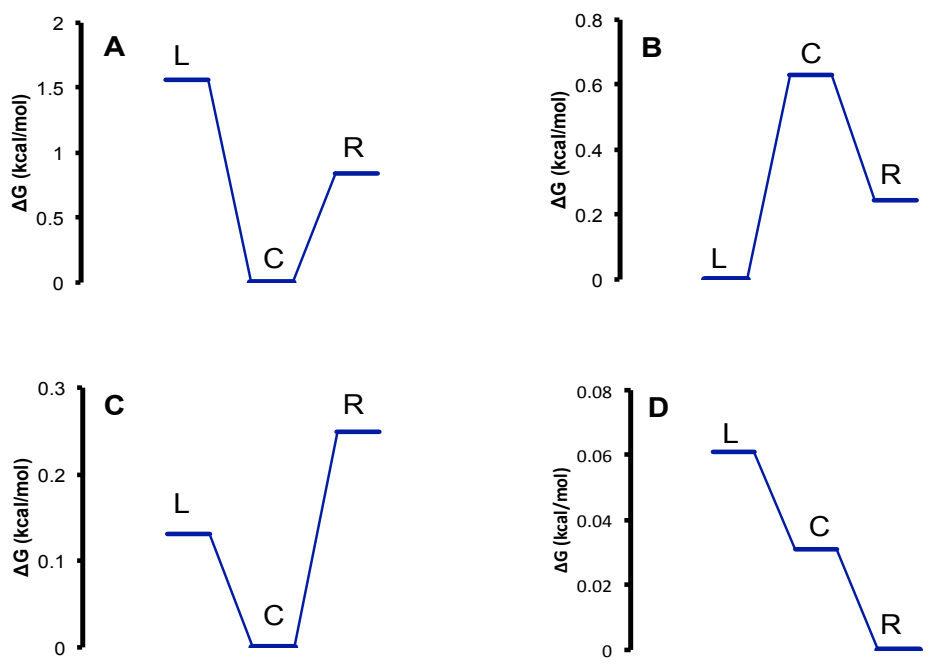

Figure 5-5: Relative energies of the three isomers for each heteroleptic compound relative to the most stable isomer. $\mathrm{L}, \mathrm{C}$ and $\mathrm{R}$ indicate the position of the unique ligand for each isomer. A) $\left.\left.\mathrm{Ni}\left(6-\mathrm{CH}_{3} \mathrm{PyS}\right)_{2}(\mathrm{PyS})^{-} \mathrm{B}\right) \mathrm{Ni}(\mathrm{PyS})_{2}\left(6-\mathrm{CH}_{3} \mathrm{PyS}\right)^{-} \mathrm{C}\right) \mathrm{Ni}(\mathrm{PyS})_{2}(3-$ $\left.\mathrm{CF}_{3} \mathrm{PyS}\right)^{-}$and $\left.\mathrm{D}\right) \mathrm{Ni}\left(3-\mathrm{CF}_{3} \mathrm{PyS}\right)_{2}(\mathrm{PyS})^{-}$. 
position is generally disfavored. For the electron poor compound $\mathrm{Ni}(\mathrm{PyS})_{2}\left(3-\mathrm{CF}_{3} \mathrm{PyS}\right)$, the most stable confirmation has the one electron poor ligand in the central position. The least stable conformation has the substituted ligand in the $\mathrm{R}$ position, though all three isomers are fairly close in energy. Compound $\mathrm{Ni}(\mathrm{PyS})_{2}\left(3-\mathrm{CF}_{3} \mathrm{PyS}\right)^{-}$is most stable when the substituted ligand is in the R position, although the distribution in energy for the three isomers of $\mathrm{Ni}(\mathrm{PyS})_{2}\left(3-\mathrm{CF}_{3} \mathrm{PyS}\right)^{-}$is the smallest of the four heteroleptic three catalysts. After determining the relative energy of each starting isomer for the four heteroleptic catalysts, the relative distribution of isomers at room temperature can be determined using a Boltzmann distribution. Although factors such as barriers to formation are not considered, this information still helps us to understand differences in catalytic activity when we begin comparing experimental and theoretical data.

Table 5-1: Relative population for the three isomers of each heteroleptic compound determined from the energies of formation of each isomer

\begin{tabular}{|c|c|c|c|}
\hline & {$[\mathrm{L}]$} & {$[\mathrm{C}]$} & [R] \\
\hline $\mathrm{Ni}(\mathrm{PyS})_{2}\left(6-\mathrm{CH}_{3} \mathrm{PyS}\right)^{-}$ & 0.1 & 1.0 & 0.2 \\
\hline $\mathrm{Ni}\left(6-\mathrm{CH}_{3} \mathrm{PyS}\right)_{2}(\mathrm{PyS})^{-}$ & 1.0 & 0.3 & 0.7 \\
\hline $\mathrm{Ni}\left(3-\mathrm{CF}_{3} \mathrm{PyS}\right)_{2}(\mathrm{PyS})^{-}$ & 0.8 & 1.0 & 0.7 \\
\hline $\mathrm{Ni}(\mathrm{PyS})_{2}\left(3-\mathrm{CF}_{3} \mathrm{PyS}\right)^{-}$ & 0.9 & 0.9 & 1.0 \\
\hline
\end{tabular}


Table 5-2: $\mathrm{p} K_{a}$ values for protonation at each of the labeled ligand positions for the three isomers of each heteroleptic compound. Cells highlighted in red indicate ligands with electron withdrawing modification and cells highlighted in green indicate ligands with electron donating modifications.

\begin{tabular}{|c|c|c|c|}
\hline Compound & L pKa & C pKa & R pKa \\
\hline $\mathrm{Ni}\left(3-\mathrm{CF}_{3} \mathrm{PyS}\right)_{2}(\mathrm{PyS})^{-[\mathrm{L}]}$ & 8.80 & 2.10 & 1.90 \\
\hline $\mathrm{Ni}\left(3-\mathrm{CF}_{3} \mathrm{PyS}\right)_{2}(\mathrm{PyS})^{-}[\mathrm{C}]$ & 5.30 & 5.20 & 5.20 \\
\hline $\mathrm{Ni}\left(3-\mathrm{CF}_{3} \mathrm{PyS}\right)_{2}(\mathrm{PyS})^{-[R]}$ & 6.50 & 2.90 & 8.40 \\
\hline $\mathrm{Ni}(\mathrm{PyS})_{2}\left(3-\mathrm{CF}_{3} \mathrm{PyS}\right)^{-[L]}$ & 7.00 & 6.30 & 8.60 \\
\hline $\mathrm{Ni}(\mathrm{PyS})_{2}\left(3-\mathrm{CF}_{3} \mathrm{PyS}\right)^{-[\mathrm{C}]}$ & 9.20 & 2.70 & 8.70 \\
\hline $\mathrm{Ni}(\mathrm{PyS})_{2}\left(3-\mathrm{CF}_{3} \mathrm{PyS}\right)^{-}[\mathrm{R}]$ & 9.10 & 5.70 & 7.10 \\
\hline $\mathrm{Ni}(\mathrm{PyS})_{2}\left(6-\mathrm{CH}_{3} \mathrm{PyS}\right)^{-}[\mathrm{L}]$ & 11.62 & 8.14 & 9.37 \\
\hline $\mathrm{Ni}(\mathrm{PyS})_{2}\left(6-\mathrm{CH}_{3} \mathrm{PyS}\right)^{-[\mathrm{C}]}$ & 8.94 & 10.31 & 9.61 \\
\hline $\mathrm{Ni}(\mathrm{PyS})_{2}\left(6-\mathrm{CH}_{3} \mathrm{PyS}\right)^{-[\mathrm{R}]}$ & 9.12 & 9.13 & 11.45 \\
\hline $\mathrm{Ni}\left(6-\mathrm{CH}_{3} \mathrm{PyS}\right)_{2}(\mathrm{PyS})^{-[\mathrm{L}]}$ & 11.20 & 15.10 & 13.10 \\
\hline $\mathrm{Ni}\left(6-\mathrm{CH}_{3} \mathrm{PyS}\right)_{2}(\mathrm{PyS})^{-[\mathrm{C}]}$ & 13.00 & 13.00 & 12.40 \\
\hline $\mathrm{Ni}\left(6-\mathrm{CH}_{3} \mathrm{PyS}\right)_{2}(\mathrm{PyS})^{-}[\mathrm{R}]$ & 11.83 & 11.77 & 10.63 \\
\hline
\end{tabular}

\section{Computed physical properties}

$\mathrm{E}^{0}$ and $\mathrm{p} K_{a}$ values were calculated for each step and intermediate along the catalytic cycle. We began our investigation of the physical properties by calculating the $\mathrm{p} K_{a}$ values for each heteroleptic catalyst (Table 5-2). The presence of multiple possible starting isomers, which are heavily influenced by the electronics and position of the ligands, greatly complicates the investigation of these properties. We must consider each possible protonation site for the initial chemical step. This means that when considering only protonation at the ligand nitrogen atom, each isomer contains three distinct protonation sites, with unique $\mathrm{p} K_{a}$ values resulting in each heteroleptic compound having nine distinct isomers following the first protonation step. The second protonation event 
could occur at one of three remaining protonation sites, the nitrogen atoms on the remaining two ligands or the central nickel atom, resulting in 27 isomers for each compound.

The nine possible $\mathrm{p} K_{a}$ values for each of the four heteroleptic catalysts for the first protonation step can be seen in Table 5-2 The mean values aid in the observation of general trends in the proton and electron affinity of each heteroleptic compound (Table 5-3). The data shows an overall trend for the initial protonation step, where adding more electron rich ligands leads to an overall increase in the $\mathrm{p} K_{a}$ of all protonation sites, despite the large variability in $\mathrm{p} K_{a}$ between isomers of the same compound. This result is in line with the results of our previous studies and our hypothesis for the current work. However, when the $\mathrm{p} K_{a}$ values are inspected more closely, it is clear that the positioning of the ligands plays an important role in influencing the proton affinity of each nitrogen as well. This observation will be expounded upon in the discussion section.

Table 5-3: Average values for $\mathrm{p} K_{a}$ and $\mathrm{E}^{0}$ values for corresponding numbered chemical $\left(\mathrm{C}_{1}\right.$ and $\left.\mathrm{C}_{2}\right)$ or electrochemical $\left(\mathrm{E}_{1}\right.$ and $\left.\mathrm{E}_{2}\right)$ steps. Specific sites of protonation are indicated.

\begin{tabular}{|c|c|c|c|c|}
\hline & $\mathrm{Ni}\left(3-\mathrm{CF}_{3} \mathrm{PyS}\right)_{2}(\mathrm{PyS})^{-}$ & $\mathrm{Ni}(\mathrm{PyS})_{2}\left(3-\mathrm{CF}_{3} \mathrm{PyS}\right)^{-}$ & $\mathrm{Ni}(\mathrm{PyS})_{2}\left(6-\mathrm{CH}_{3} \mathrm{PyS}\right)^{-}$ & $\mathrm{Ni}\left(6-\mathrm{CH}_{3} \mathrm{PyS}\right)_{2}(\mathrm{PyS})$ \\
\hline $\mathrm{C}_{1}\left(\mathrm{p} K_{a}\right)$ & 5.1 & 7.2 & 9.7 & 12.4 \\
\hline$E_{1}\left(E^{0}\right)$ & -1.46 & -1.57 & -1.60 & -1.72 \\
\hline $\mathrm{C}_{2}$ nickel $\left(\mathrm{p} K_{a}\right)$ & 0.24 & 3.24 & 2.40 & 3.69 \\
\hline $\mathrm{C}_{2}$ nitrogen $\left(\mathrm{p} K_{a}\right)$ & 11.51 & 13.09 & 14.58 & 16.52 \\
\hline$E_{2}$ nickel $\left(E^{0}\right)$ & -1.96 & -2.10 & -2.29 & -2.17 \\
\hline$E_{2}$ nitrogen $\left(E^{0}\right)$ & -1.07 & -1.05 & -1.1 & -1.59 \\
\hline $\mathrm{C}_{2}\left(\mathrm{p} K_{a}\right)$ & - & - & 3.44 & 5.1 \\
\hline
\end{tabular}


For a CECE mechanism, reduction is the next step that must be investigated. Reduction potentials were calculated for any compounds that could be protonated at neutral $\mathrm{pH}$, or in the case of the most electron poor catalyst $\mathrm{Ni}\left(3-\mathrm{CF}_{3} \mathrm{PyS}\right)_{2}(\mathrm{PyS})^{-}$, for those compounds with $\mathrm{p} K_{a}$ values greater than 5 (Table 5-4). The trend in the reduction potentials for the four heteroleptic compounds is as expected, with the most electron poor compound $\mathrm{Ni}\left(3-\mathrm{CF}_{3} \mathrm{PyS}\right)_{2}(\mathrm{PyS})^{-}$having the lowest average reduction potential and the most electron rich compound $\mathrm{Ni}\left(6-\mathrm{CH}_{3} \mathrm{PyS}\right)_{2}(\mathrm{PyS})^{-}$having the highest average reduction potential.

As mentioned previously, for each compound there are three possible sites of

Table 5-4: Reduction potentials for isomers of each heteroleptic compound. Columns indicate which ligand was protonated in the previous step. Only compounds with $\mathrm{p} K_{a}$ values greater than 5 were considered. Cells highlighted in red indicate ligands with electron withdrawing modification and cells highlighted in green indicate ligands with electron donating modifications.

\begin{tabular}{|c|c|c|c|}
\hline Compound & $L^{0} E^{0}$ & $\mathrm{CE}^{0}$ & $\mathrm{RE}^{\mathbf{0}}$ \\
\hline $\mathrm{Ni}\left(3-\mathrm{CF}_{3} \mathrm{PyS}\right)_{2}(\mathrm{PyS})^{-[L]}$ & -1.53 & - & - \\
\hline $\mathrm{Ni}\left(3-\mathrm{CF}_{3} \mathrm{PyS}\right)_{2}(\mathrm{PyS})^{-}[\mathrm{C}]$ & -1.41 & -1.33 & -1.51 \\
\hline $\mathrm{Ni}\left(3-\mathrm{CF}_{3} \mathrm{PyS}\right)_{2}(\mathrm{PyS})^{-[R]}$ & - & - & -1.54 \\
\hline $\mathrm{Ni}(\mathrm{PyS})_{2}\left(3-\mathrm{CF}_{3} \mathrm{PyS}\right)^{-[\mathrm{L}]}$ & -1.53 & - & -1.56 \\
\hline $\mathrm{Ni}(\mathrm{PyS})_{2}\left(3-\mathrm{CF}_{3} \mathrm{PyS}\right)^{-}[\mathrm{C}]$ & -1.56 & - & -1.61 \\
\hline $\mathrm{Ni}(\mathrm{PyS})_{2}\left(3-\mathrm{CF}_{3} \mathrm{PyS}\right)^{-[R]}$ & -1.52 & - & -1.62 \\
\hline $\mathrm{Ni}(\mathrm{PyS})_{2}\left(6-\mathrm{CH}_{3} \mathrm{PyS}\right)^{-}[\mathrm{L}]$ & -1.67 & -1.50 & -1.70 \\
\hline $\mathrm{Ni}(\mathrm{PyS})_{2}\left(6-\mathrm{CH}_{3} \mathrm{PyS}\right)^{-}[\mathrm{C}]$ & -1.60 & -1.56 & -1.57 \\
\hline $\mathrm{Ni}(\mathrm{PyS})_{2}\left(6-\mathrm{CH}_{3} \mathrm{PyS}\right)^{-[\mathrm{R}]}$ & -1.55 & -1.55 & -1.67 \\
\hline $\mathrm{Ni}\left(6-\mathrm{CH}_{3} \mathrm{PyS}\right)_{2}(\mathrm{PyS})^{-[\mathrm{L}]}$ & -2.21 & -1.55 & -1.86 \\
\hline $\mathrm{Ni}\left(6-\mathrm{CH}_{3} \mathrm{PyS}\right)_{2}(\mathrm{PyS})^{-}[\mathrm{C}]$ & -1.65 & -1.71 & -1.69 \\
\hline $\mathrm{Ni}\left(6-\mathrm{CH}_{3} \mathrm{PyS}\right)_{2}(\mathrm{PyS})^{-[R]}$ & -1.54 & -1.55 & -1.72 \\
\hline
\end{tabular}


protonation for the second chemical step, the remaining two nitrogen atoms of the ligands and the central nickel. The $\mathrm{p} K_{a}$ values for protonation at each of these sites were computed for viable intermediates (Appendix Table 1). Protonation at the metal center for nearly every isomer of the four heteroleptic complexes is thermodynamically disfavored. However, we have previously shown migration is possible from a ligand nitrogen to the nickel atom. Proton affinities at the metal center are similar for all four compounds.

Two unique nitrogen protonation sites exist for each isomer for the second chemical step and can both be protonated (Appendix Table 1). The $\mathrm{p} K_{a}$ values computed for second protonation at the remaining nitrogen sites follow the trend that is expected given the type and number of ligands present. The most electron rich compound is most easily protonated while the most electron poor compound has the lowest proton affinity. The computed $\mathrm{p} K_{a}$ values for these compounds are generally quite large and may lead to thermodynamic sinks and inert intermediates.

Finally, reduction potentials for the second electrochemical step in a CECE mechanism were computed for compounds where the second protonation occurred at the metal center, as well as for compounds where second protonation occurred on a ligand (Appendix Table 2). These reduction potentials also follow the expected trend, with higher overpotentials noted for more electron rich compounds and lower overpotentials noted for electron poor compounds. When the twice protonated intermediate has one proton located at the metal center rather than a second ligand, the required reduction 
potential is significantly lower for all four heteroleptic compounds. The trends in reduction potentials for intermediates protonated at the metal center do not track exactly with the number and type of ligand.

\subsubsection{Experimental results}

Experimentally, the four heteroleptic compounds were synthesized, characterized, and subsequently tested for their ability to produce hydrogen electrochemically. The synthesis of heteroleptic compounds is uniquely challenging in that the thermodynamic formation of homoleptic compounds may be favored, or one heteroleptic compound may be more thermodynamically favored than the other, causing mixture of compounds in solution. Even if care is taken to promote the formation of the heteroleptic compound, the existence of the three isomers for each heteroleptic catalyst further complicates the synthesis of a single, pure product. There are thermodynamic differences in the formation of the three isomers of the electron rich heteroleptic compounds $\mathrm{Ni}\left(6-\mathrm{NiCH}_{3} \mathrm{PyS}\right)_{2}(\mathrm{PyS})^{-}$ and $\mathrm{Ni}(\mathrm{PyS})_{2}\left(6-\mathrm{CH}_{3} \mathrm{PyS}\right)^{-} v s$ the possible homoleptic products $\mathrm{Ni}\left(6-\mathrm{CH}_{3} \mathrm{PyS}\right)_{3}^{-}$and $\mathrm{Ni}(\mathrm{PyS})_{3}$. The same is true for electron poor heteroleptic compounds $\mathrm{Ni}(3-$ $\left.\mathrm{CF}_{3} \mathrm{PyS}\right)_{2}(\mathrm{PyS})^{-}$and $\mathrm{Ni}(\mathrm{PyS})_{2}\left(3-\mathrm{CF}_{3} \mathrm{PyS}\right)^{-} v s$ their homoleptic counterparts $\mathrm{Ni}(3-$ $\left.\mathrm{CF}_{3} \mathrm{PyS}\right)_{3}{ }^{-}$and $\mathrm{Ni}(\mathrm{PyS})_{3}{ }^{-}$. Our strategy to promote the formation of the desired heteroleptic product was to carry out the synthesis in a two-step fashion. Addition of the majority ligand was performed first, followed by addition of the third ligand to generate the final octahedral $\mathrm{Ni}(\mathrm{II})$ compound. Color changes during the course of synthesis suggest transition from the intermediate nickel compound to the final compound did 
occur. The detailed synthetic procedures for each heteroleptic compound are explained in the experimental section.

The identity and properties of the compounds were probed through the use of mass spectroscopy, UV-vis absorption spectroscopy and cyclic voltammetry. When possible, the results of experimental characterization were compared to computationally generated data. Cyclic voltammetry and UV-vis absorption spectroscopy were also used to experimentally determine $\mathrm{E}^{0}$ and $\mathrm{p} K_{a}$ values, respectively. Because the reductions are irreversible, $\mathrm{E}^{0}$ for each compound was chosen to be the point at which the maximum current was passed. The rate of hydrogen production, $k_{\mathrm{obs}}$ was determined for each compound through titration of a solution of catalyst with 4-cyanoanilinium. In addition to $k_{\mathrm{obs}}$, insight into the mechanism of hydrogen formation could be obtained through interpretation of the shape of the $\mathrm{CV}$ traces, aided by comparison of $\mathrm{E}^{0}$ with computational results. $^{85,197,209}$

The presence of multiple isomers of the same catalyst adds an element of complexity to the study of their kinetics. We thus chose one systematic approach to report $k_{\mathrm{obs}}$, keeping in mind that we are only looking at observed rates for the purposes of assessing how they are affected by differences in the type and number of ligand modifications. The analysis of selected cyclic voltammograms is detailed in the discussion section to illustrate how this kind of electrochemical study can be used to understand heteroleptic compounds. 


\subsubsection{UV-vis absorbance spectroscopy}

UV-vis absorbance spectra were taken for each heteroleptic compound under both acidic and basic conditions (Figure 5-6). The $\lambda_{\max }$ values for each compound under acidic and basic conditions can be seen listed in Table 5-5. Distinct absorbance peaks are seen for all compounds. The electron rich compounds have the same $\lambda_{\max }$ values for the highenergy transition, but different values of $\lambda_{\max }$ for the low-energy transition (Figure 5-6A). Both of the electron poor heteroleptic catalysts have unique $\lambda_{\max }$ values for the high and low energy transitions (Figure 5-6C). For all four heteroleptic compounds a bathochromic shift is observed when the catalyst becomes protonated. This shift was used to identify the relative concentration of the deprotonated $v s$ protonated product in solution at various $\mathrm{pH}$ 's and obtain $\mathrm{p} K_{a}$ values. Within the visible region, a second absorption is observed for the electron rich compounds, attributed to a $\mathrm{d}$ to $\mathrm{d}$ transition at the nickel center. The $\lambda_{\max }$ values resulting from these transitions shift bathochromically as electron density increases in the ligands. For the electron poor compounds, there is no peak in the visible range due to overlap with the higher energy peak (Appendix Figure 12). The absorbance of two mixtures of the homoleptic catalysts $\mathrm{Ni}(\mathrm{PyS})_{3}{ }^{-}$and $\mathrm{Ni}\left(3-\mathrm{CF}_{3} \mathrm{PyS}\right)_{3}{ }^{-}$were measured under acidic and basic conditions. These solutions contained 2:1 and 1:2 ratios of the two homoleptic products. Absorption maxima for the mixtures are distinct from those of the heteroleptic compounds. 

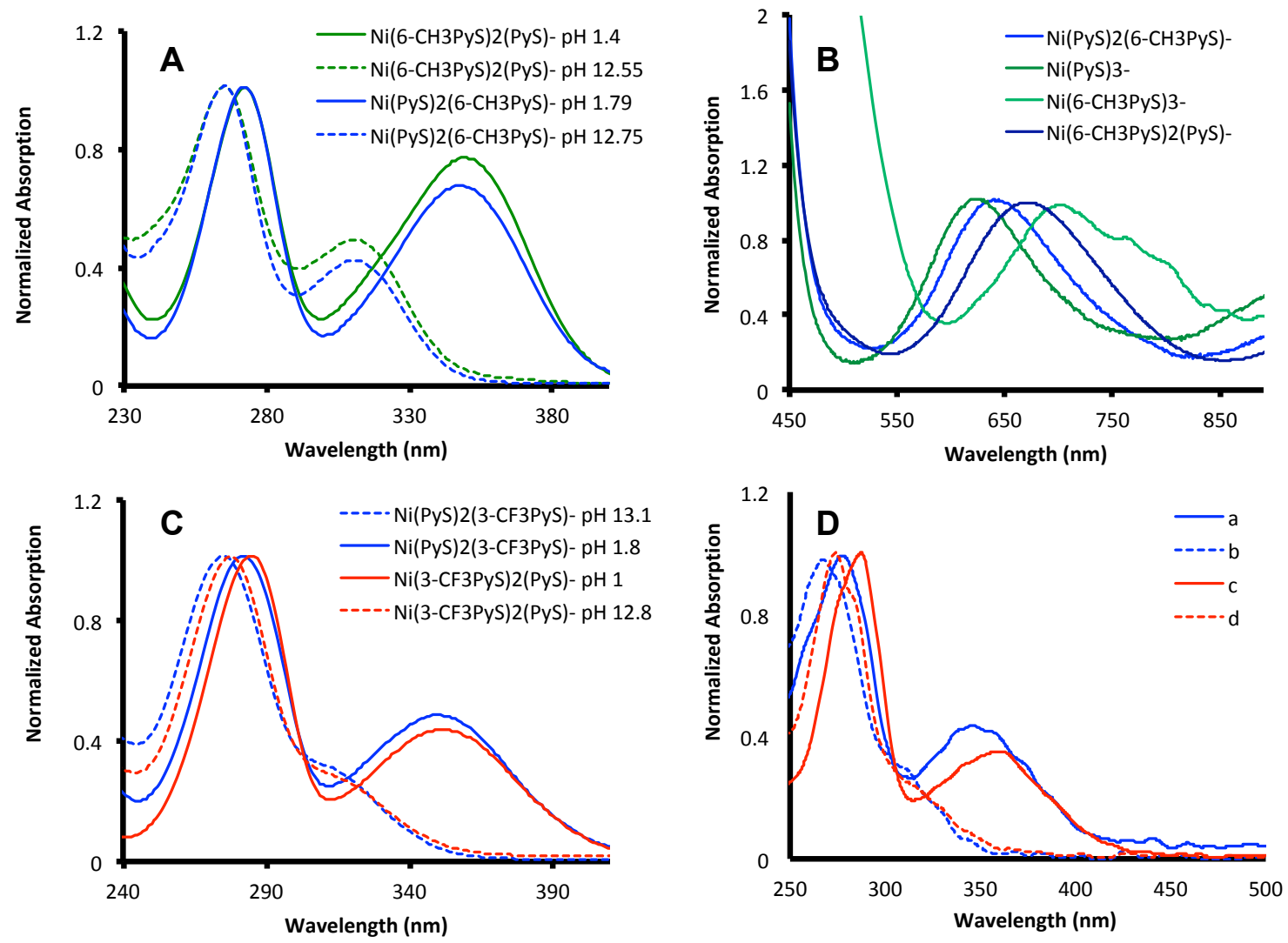

Figure 5-6: A) Experimentally acquired spectra of $\mathrm{Ni}\left(6-\mathrm{CH}_{3} \mathrm{PyS}\right)_{2}(\mathrm{PyS})^{-}$(green) and $\mathrm{Ni}(\mathrm{PyS})_{2}\left(6-\mathrm{CH}_{3} \mathrm{PyS}\right)^{-}$(blue) in the UV and near UV region under both acidic and basic conditions. B) Experimentally acquired UV-vis absorbance spectra of compounds $\mathrm{Ni}(\mathrm{PyS})_{3}{ }^{-}, \mathrm{Ni}(\mathrm{PyS})_{2}\left(6-\mathrm{CH}_{3} \mathrm{PyS}\right)^{-}, \mathrm{Ni}\left(6-\mathrm{CH}_{3} \mathrm{PyS}\right)_{2}(\mathrm{PyS})^{-}$and $\mathrm{Ni}\left(6-\mathrm{CH}_{3} \mathrm{PyS}\right)_{3}{ }^{-}$from left to right, showing the visible region where $\mathrm{d}$ to $\mathrm{d}$ metal transitions can be observed under neutral conditions $\mathrm{C}$ ) Experimentally acquired spectra of $\mathrm{Ni}\left(3-\mathrm{CF}_{3} \mathrm{PyS}\right)_{2}(\mathrm{PyS})^{-}$(red) and $\mathrm{Ni}(\mathrm{PyS})_{2}\left(3-\mathrm{CF}_{3} \mathrm{PyS}\right)^{-}$(blue) in the UV and near UV region. Dashed lines indicate solutions measured at $\mathrm{pH} 13$ and solid lines indicate solutions measured at $\mathrm{pH} 1.5 \mathrm{D}$ ) Experimentally acquired spectra of solution of a) $2: 1 \mathrm{Ni}(\mathrm{PyS})_{3}{ }^{-}$to $\mathrm{Ni}\left(3-\mathrm{CF}_{3} \mathrm{PyS}\right)_{3}{ }^{-}$at $\mathrm{pH}$ 13 b) $2: 1 \mathrm{Ni}(\mathrm{PyS})_{3}{ }^{-}$to $\mathrm{Ni}\left(3-\mathrm{CF}_{3} \mathrm{PyS}\right)_{3}{ }^{-}$at $\left.\mathrm{pH} 1.5 \mathrm{c}\right) 2: 1 \mathrm{Ni}\left(3-\mathrm{CF}_{3} \mathrm{PyS}\right)_{3}{ }^{-}$to $\mathrm{Ni}(\mathrm{PyS})_{3}{ }^{-}$at $\mathrm{pH}$ 13 d) $2: 1 \mathrm{Ni}\left(3-\mathrm{CF}_{3} \mathrm{PyS}\right)_{3}{ }^{-}$to $\mathrm{Ni}(\mathrm{PyS})_{3}{ }^{-}$at $\mathrm{pH} 1.5$. 
Table 5-5: Measured $\lambda_{\max }$ values for each heteroleptic complex in both acidic and basic conditions. Absorbance values in the visible region corresponding to $d$ to $d$ transitions included as well

\begin{tabular}{|c|c|c|c|}
\hline & $\lambda_{\max }$ basic $(\mathrm{nm})$ & $\lambda_{\max }$ acidic $(\mathrm{nm})$ & $\lambda_{\max } d$ to $d(n m)$ \\
\hline $\mathrm{Ni}\left(6-\mathrm{CH}_{3} \mathrm{PyS}\right)_{3}$ & 310 & 347 & 612 \\
\hline $\mathrm{Ni}\left(6-\mathrm{CH}_{3} \mathrm{PyS}\right)_{2}(\mathrm{PyS})^{-}$ & 275,321 & 284,355 & 628 \\
\hline $\mathrm{Ni}(\mathrm{PyS})_{2}\left(6-\mathrm{CH}_{3} \mathrm{PyS}\right)^{-}$ & 275,316 & 284,352 & 656 \\
\hline $\mathrm{Ni}(\mathrm{PyS})_{3}$ & $\mathrm{~N} / \mathrm{A}$ & $\mathrm{N} / \mathrm{A}$ & 682 \\
\hline $\mathrm{Ni}(\mathrm{PyS})_{2}\left(3-\mathrm{CF}_{3} \mathrm{PyS}\right)^{-}$ & 260,305 & 270,343 & N/A \\
\hline $\mathrm{Ni}\left(3-\mathrm{CF}_{3} \mathrm{PyS}\right)_{2}(\mathrm{PyS})^{-}$ & 264,305 & 269,345 & N/A \\
\hline $\mathrm{Ni}\left(3-\mathrm{CF}_{3} \mathrm{PyS}\right)_{3}$ & 275,308 & 280,350 & N/A \\
\hline
\end{tabular}

\subsection{4. pKa values}

The $\mathrm{p} K_{a}$ was determined using the absorption spectra of the fully deprotonated compound and monitoring both changes in absorbance and $\mathrm{pH}$ as acid was titrated into the solution. A titration curve plotting the ratio of $\lambda_{\max }$ for the protonated and deprotonated compounds as a function of $\mathrm{pH}$ was generated. The UV-vis absorbance data of the electron rich compound $\mathrm{Ni}(\mathrm{PyS})_{2}\left(6-\mathrm{CH}_{3} \mathrm{PyS}\right)^{-}$can be seen in Figure 5-7, as an example, along with the corresponding plot of absorbance ratio $v s \mathrm{pH}$. The inflection point of this titration curve corresponds to the $\mathrm{p} K_{a}$ of the compound in solution. Remaining spectra and plots for the other three heteroleptic compounds can be seen in the Appendix. Due to the existence of multiple isomers of each compound in solution, the experimental determination of physical properties becomes complicated. For example, in the evaluation of $\mathrm{p} K_{a}$ values for certain homoleptic compounds, clear isosbestic points 
can be seen, indicating direct transformation of the unprotonated to the protonated compound. For heteroleptic compounds, the lack of an isosbestic point found in UV-vis spectra likely results from the isomers being protonated and those resulting after protonation. Thus, the extracted $\mathrm{p} K_{a}$ value is taken as an average of all species in solution. Experimentally measured $\mathrm{p} K_{a}$ values can be seen in Table 5-6. Measured $\mathrm{p} K_{a}$ values follow the expected trend, based on the electronic properties of the ligands. More electron rich ligands have higher measured $\mathrm{p} K_{a}$ values and more electron poor catalysts have lower $\mathrm{p} K_{a}$ values. The previously measured values of the homoleptic compounds $\mathrm{Ni}\left(6-\mathrm{CH}_{3} \mathrm{PyS}\right)_{3}{ }^{-}, \mathrm{Ni}(\mathrm{PyS})_{3}{ }^{-}$and $\mathrm{Ni}\left(3-\mathrm{CF}_{3} \mathrm{PyS}\right)_{3}{ }^{-}$also follow the expected trend.
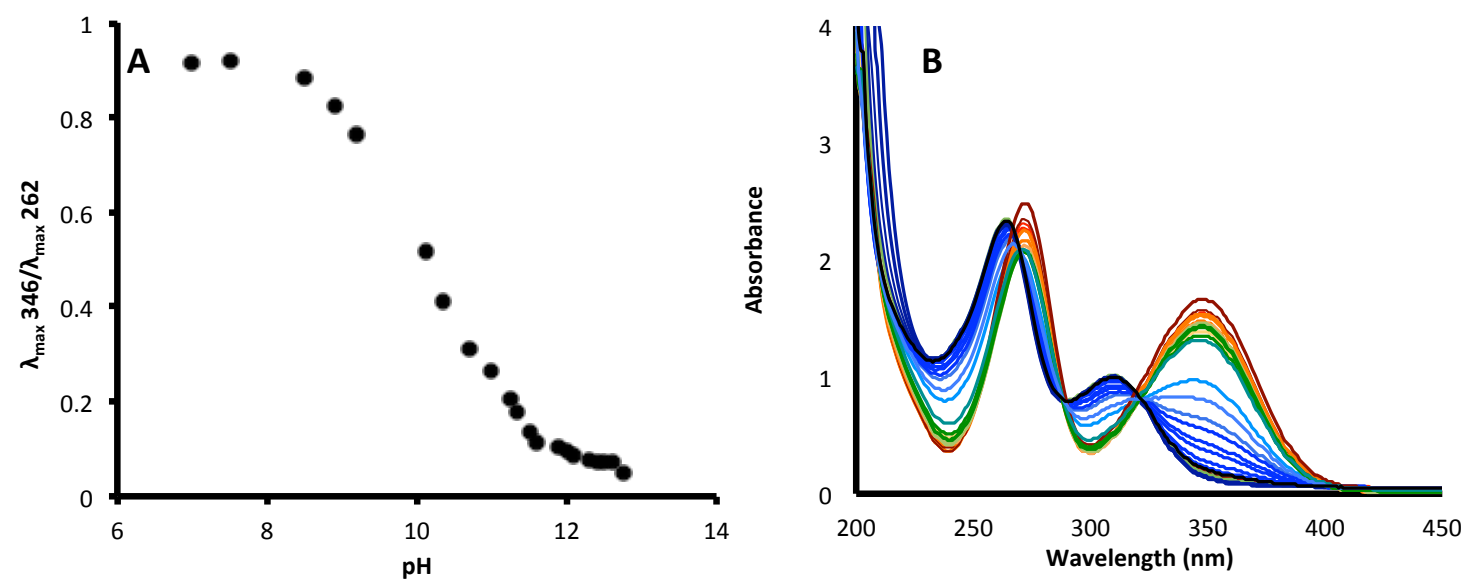

Figure 5-7: $\mathrm{Ni}(\mathrm{PyS})_{2}\left(6-\mathrm{CH}_{3} \mathrm{PyS}\right)^{-}$data $\left.\mathrm{A}\right)$ absorbance ratio of protonated and deprotonated catalyst as a function of $\mathrm{pH}$ where inflection point is used to determine $\mathrm{p} K_{a}$ B) UV-vis absorbance spectra.

\subsection{5. $\mathrm{E}^{0}$ values}

Reduction potentials were measured using cyclic voltammetry. Without addition of acid, no reduction peak is seen in the scan window of $0.5 \mathrm{~V}$ to $-2.00 \mathrm{~V}$ vs SCE using a $10^{-3} \mathrm{M}$ solution of catalyst. Following the first addition of acid, a peak corresponding to 
the $\mathrm{Ni}(\mathrm{II}) / \mathrm{Ni}(\mathrm{I})$ (Appendix Figure 13) is observed for all four compounds. A catalytic wave was observed with increasing acid concentration. Experimentally measured reduction potentials can be seen in Table 5-6 and cyclic voltammograms can be seen in Appendix Figure 14 to Appendix Figure 16.

\subsubsection{Electrochemical rates of hydrogen production}

The rate of hydrogen production was measured by determining the catalytic current under high acid conditions, with the applied potential swept from $0.5 \mathrm{~V}$ vs SCE to $-2.0 \mathrm{~V}$ vs SCE. The acid independent regime was determined by titration of a $10^{-3} \mathrm{M}$ solution of catalyst with 4-cyanoanilinium until a linear dependence on the acid concentration could no longer be identified for the current response. An initial scan was run with a concentration of $5.4 \times 10^{-3} \mathrm{M}$ 4-cyanoanilinium, with the potential swept from $0.5 \mathrm{~V}$ vs SCE to $-2.0 \mathrm{~V}$ vs SCE, to establish the current response corresponding to reduction of the catalyst, to get $i_{\mathrm{p}}$. A subsequent scan under the same conditions was run after increasing the concentration of 4-cyanoanilinium to $2.2 \times 10^{-2} \mathrm{M}$. At this concentration the reaction rate is no longer affected by depletion of acid at the electrode

Table 5-6: Values for $\mathrm{E}^{0}$ and $\mathrm{p} K_{a}$ determined experimentally for homoleptic and heteroleptic compounds. For $\mathrm{Ni}\left(6-\mathrm{CH}_{3} \mathrm{PyS}\right)_{3}{ }^{-}$the reported values are computational values for the CECE mechanism for comparison purposes. ${ }^{\mathrm{e}}$ Indicates experimentally obtained values and ${ }^{\mathrm{c}}$ denotes computed values.

\begin{tabular}{|c|c|c|c|c|c|c|c|}
\hline & $\mathrm{Ni}(\mathrm{PyS})_{3}$ & $\begin{array}{l}\mathrm{Ni}(6- \\
\left.\mathrm{CH}_{3} \mathrm{PyS}\right)_{3}^{-}\end{array}$ & $\begin{array}{l}\mathrm{Ni}(6- \\
\left.\mathrm{CH}_{3} \mathrm{PyS}\right)_{2}(\mathrm{PyS})^{-}\end{array}$ & $\begin{array}{l}\mathrm{Ni}(\mathrm{PyS})_{2}(6- \\
\left.\mathrm{CH}_{3} \mathrm{PyS}\right)^{-}\end{array}$ & $\begin{array}{l}\mathrm{Ni}(\mathrm{PyS})_{2}(3- \\
\left.\mathrm{CF}_{3} \mathrm{PyS}\right)^{-}\end{array}$ & $\begin{array}{l}\mathrm{Ni}(3- \\
\left.\mathrm{CF}_{3} \mathrm{PyS}\right)_{2}(\mathrm{PyS})^{-}\end{array}$ & $\begin{array}{l}\mathrm{Ni}(3- \\
\left.\mathrm{CF}_{3} \mathrm{PyS}\right)_{3}\end{array}$ \\
\hline $\mathrm{p} K_{a}{ }^{\mathrm{e}}$ & $12.0^{\mathrm{e}}$ & $16.3^{c}$ & $11.2^{\mathrm{e}}$ & $10.2^{\mathrm{e}}$ & $9.8^{\mathrm{e}}$ & $9.5^{\mathrm{e}}$ & $6.3^{\mathrm{e}}$ \\
\hline $\begin{array}{l}\mathrm{E}^{0} \mathrm{e}^{\mathrm{e}} \mathrm{V} \text { vs } \\
\mathrm{SCE}\end{array}$ & $-1.62^{\mathrm{e}}$ & $-1.55^{c}$ & $-1.55^{\mathrm{e}}$ & $-1.55^{\mathrm{e}}$ & $-1.44^{\mathrm{e}}$ & $-1.42^{\mathrm{e}}$ & $-1.26^{\mathrm{e}}$ \\
\hline
\end{tabular}


surface. Cyclic voltammograms can be seen in Appendix Figure 17. The measured current corresponds to $i_{\text {cat }}$ and is used to calculate the rate of hydrogen production. The measured rates of hydrogen production are $4400 \mathrm{~s}^{-1}$ for $\mathrm{Ni}\left(6-\mathrm{CH}_{3} \mathrm{PyS}\right)_{2}(\mathrm{PyS})^{-}, 3300 \mathrm{~s}^{-1}$ for $\mathrm{Ni}(\mathrm{PyS})_{2}\left(6-\mathrm{CH}_{3} \mathrm{PyS}\right)^{-}, 2100 \mathrm{~s}^{-1}$ for $\mathrm{Ni}(\mathrm{PyS})_{2}\left(3-\mathrm{CF}_{3} \mathrm{PyS}\right)^{-}$and $3200 \mathrm{~s}^{-1}$ for $\mathrm{Ni}(3-$ $\left.\mathrm{CF}_{3} \mathrm{PyS}\right)_{2}(\mathrm{PyS})^{-}$, compared to $332 \mathrm{~s}^{-1}$ and $42 \mathrm{~s}^{-1}$ for $\mathrm{Ni}\left(6-\mathrm{CH}_{3} \mathrm{PyS}\right)_{3}{ }^{-}$and $\mathrm{Ni}\left(3-\mathrm{CF}_{3} \mathrm{PyS}\right)_{3}{ }^{-}$.

\subsubsection{Mass spectroscopy results}

Mass spectra were taken for each of the four heteroleptic catalysts (Appendix Figure 18). Computed values for the mass peaks of each compound along with fragments of importance and measured values can be seen in Table 5-7. The calculated mass peak for the most electron poor compound $\mathrm{Ni}\left(3-\mathrm{CF}_{3} \mathrm{PyS}\right)_{2}(\mathrm{PyS})^{-}$was found experientally at 523.87260. For the second electron poor compound $\mathrm{Ni}(\mathrm{PyS})_{2}\left(3-\mathrm{CF}_{3} \mathrm{PyS}\right)^{-}$, the mass peak was not observed. For both of the electron rich compounds, $\mathrm{Ni}\left(6-\mathrm{CH}_{3} \mathrm{PyS}\right)_{2}(\mathrm{PyS})^{-}$and $\mathrm{Ni}(\mathrm{PyS})_{2}\left(6-\mathrm{CH}_{3} \mathrm{PyS}\right)^{-}$the peaks corresponding to ligands $\mathrm{PyS}^{-}$and $6-\mathrm{CH}_{3} \mathrm{PyS}^{-}$were found. We have previously noted that for electron rich compounds, only the ligand peaks are observed in the mass spectra. For $\mathrm{Ni}\left(6-\mathrm{CH}_{3} \mathrm{PyS}\right)_{2}(\mathrm{PyS})^{-}$, ligands $\mathrm{PyS}^{-}$and $6-\mathrm{CH}_{3} \mathrm{PyS}{ }^{-}$ appear in a 2:10 ratio, while for compound $\mathrm{Ni}(\mathrm{PyS})_{2}\left(6-\mathrm{CH}_{3} \mathrm{PyS}\right)^{-}$they appear in a 9:10 ratio. Complication in the identification of metal-pyridinethiolate complexes using ESI mass spectroscopy could be arising from transformations such as the oxidation of analyte into disulfide species, as has been reported in a comprehensive mass spectroscopy study on the behavior of 2-mercaptopyridine metal complexes. ${ }^{210}$ 
Table 5-7: Mass spectra data for heteroleptic compounds. Each compound tested is highlighted in bold with important fragments listen underneath, along with their expected masses and measured masses.

\begin{tabular}{|c|c|c|c|c|}
\hline Compound & Formula & Calculated & Found & Counts \\
\hline \multicolumn{5}{|l|}{$\mathrm{Ni}\left(6-\mathrm{CH}_{3} \mathrm{PyS}\right)_{2}(\mathrm{PyS})^{-}$} \\
\hline $\mathrm{Ni}\left(6-\mathrm{CH}_{3} \mathrm{PyS}\right)_{2}(\mathrm{PyS})^{-}$ & $\mathrm{NiN}_{3} \mathrm{~S}_{3} \mathrm{C}_{17} \mathrm{H}_{19}$ & 419.00946 & N/A & \\
\hline $6-\mathrm{CH}_{3} \mathrm{PyS}^{-}$ & $\mathrm{C}_{6} \mathrm{H}_{6} \mathrm{NS}$ & 124.02209 & 124.00998 & 100 \\
\hline Pys- & $\mathrm{C}_{5} \mathrm{H}_{4} \mathrm{NS}$ & 110.00644 & 109.99496 & 20 \\
\hline \multicolumn{5}{|l|}{$\mathrm{Ni}(\mathrm{PyS})_{2}\left(6-\mathrm{CH}_{3} \mathrm{PyS}\right)^{-}$} \\
\hline $\mathrm{Ni}(\mathrm{PyS})_{2}\left(6-\mathrm{CH}_{3} \mathrm{PyS}\right)^{-}$ & $\mathrm{NiN}_{3} \mathrm{~S}_{3} \mathrm{C}_{17} \mathrm{H}_{19}$ & 419.00946 & N/A & \\
\hline 6- $\mathrm{CH}_{3} \mathrm{PyS}-$ & $\mathrm{C}_{6} \mathrm{H}_{6} \mathrm{NS}$ & 124.02209 & 124.00998 & 92 \\
\hline Pys- & $\mathrm{C}_{5} \mathrm{H}_{4} \mathrm{NS}$ & 110.00644 & 109.99566 & 100 \\
\hline \multicolumn{5}{|l|}{$\mathrm{Ni}\left(3-\mathrm{CF}_{3} \mathrm{PyS}\right)_{2}(\mathrm{PyS})^{-}$} \\
\hline $\mathrm{Ni}\left(3-\mathrm{CF}_{3} \mathrm{PyS}\right)_{2}(\mathrm{PyS})^{-}$ & $\mathrm{C}_{17} \mathrm{H}_{10} \mathrm{~N}_{3} \mathrm{~S}_{3} \mathrm{~F}_{6} \mathrm{Ni}$ & 523.929453 & 523.87260 & 5 \\
\hline \multicolumn{5}{|l|}{$\mathrm{Ni}(\mathrm{PyS})_{2}\left(3-\mathrm{CF}_{3} \mathrm{PyS}\right)^{-}$} \\
\hline $\mathrm{Ni}(\mathrm{PyS})_{2}\left(3-\mathrm{CF}_{3} \mathrm{PyS}\right)^{-}$ & $\mathrm{C}_{16} \mathrm{H}_{11} \mathrm{~N}_{3} \mathrm{~S}_{3} \mathrm{~F}_{3} \mathrm{Ni}$ & 455.942069 & N/A & \\
\hline
\end{tabular}

\subsection{Discussion}

\subsubsection{Support for formation of heteroleptic compounds}

The identity of the complexes in solution was supported by considering UV-vis absorption spectroscopy in conjunction with measured physical properties and some mass spectral data. Absorbance data for the four heteroleptic catalysts studied supports the existence of these compounds in solution. The UV-vis absorbance spectra of solutions of the electron rich catalysts $\mathrm{Ni}\left(6-\mathrm{CH}_{3} \mathrm{PyS}\right)_{2}(\mathrm{PyS})^{-}$vs $\mathrm{Ni}(\mathrm{PyS})_{2}\left(6-\mathrm{CH}_{3} \mathrm{PyS}\right)^{-}$in acetonitrile, as well as the homoleptic complexes $\mathrm{Ni}\left(6-\mathrm{CH}_{3} \mathrm{PyS}\right)_{3}{ }^{-}$and $\mathrm{Ni}(\mathrm{PyS})_{3}{ }^{-}$, each have a unique absorption profile at neutral $\mathrm{pH}$ (Table 5-6). In particular, the lowest energy $\mathrm{d}$ to $\mathrm{d}$ 
transition appears in the range between $615 \mathrm{~nm}$ and $685 \mathrm{~nm}$, and each has a unique $\lambda_{\max }$, with a bathochromic shift increasing as the number of electron rich ligands is increased, as would be expected (Table 5-6A). This suggests that each of these solutions contain unique compounds. In the UV region, the absorbance spectra of $\mathrm{Ni}\left(6-\mathrm{CH}_{3} \mathrm{PyS}\right)_{2}(\mathrm{PyS})^{-}$ and $\mathrm{Ni}(\mathrm{PyS})_{2}\left(6-\mathrm{CH}_{3} \mathrm{PyS}\right)^{-}$are more similar, both under acidic and basic conditions, however they are distinct from one another (Table 5-6C).

The formation of unique electron rich heteroleptic products is further supported by the experimentally measured $\mathrm{p} K_{a}$ values. The most electron rich compound, $\mathrm{Ni}(6-$ $\left.\mathrm{CH}_{3} \mathrm{PyS}\right)_{2}(\mathrm{PyS})^{-}$, has the highest experimentally determined $\mathrm{p} K_{a}$ value of 11.2 . Compound $\mathrm{Ni}(\mathrm{PyS})_{2}\left(6-\mathrm{CH}_{3} \mathrm{PyS}\right)^{-}$has a value of 10.2 . These $\mathrm{p} K_{a}$ values for the heteroleptic compounds also fall between the measured values for the homoleptic analogues as would be expected. All values can be seen in Table 5-6. These distinct experimentally measured $\mathrm{p} K_{a}$ values offer additional support that both heteroleptic compounds were made.

The formation of the electron rich heteroleptic compounds was further investigated through the use of high-resolution ESI mass spectroscopy. For compounds $\mathrm{Ni}(\mathrm{PyS})_{2}\left(6-\mathrm{CH}_{3} \mathrm{PyS}\right)^{-}$and $\mathrm{Ni}\left(6-\mathrm{CH}_{3} \mathrm{PyS}\right)_{2}(\mathrm{PyS})^{-}$, peaks are expected at 404.99381 and 419.00946, correspoding to $\mathrm{N}_{3} \mathrm{~S}_{3} \mathrm{C}_{16} \mathrm{H}_{17} \mathrm{Ni}$ and $\mathrm{N}_{3} \mathrm{~S}_{3} \mathrm{C}_{17} \mathrm{H}_{19} \mathrm{Ni}$ respectively. The $\mathrm{PyS}^{-}$and 6- $\mathrm{CH}_{3} \mathrm{PyS}^{-}$ligands are expected to yield mass peaks at $110.00644\left(\mathrm{C}_{5} \mathrm{H}_{4} \mathrm{NS}\right)$ and 124.02209 $\left(\mathrm{C}_{6} \mathrm{H}_{6} \mathrm{NS}\right)$. As has been noted in our previous work, electron rich compounds are prone to complete dissociation using ESI. Not surprisingly, mass spectra of both 
electron rich compounds show peaks corresponding to ligands $\mathrm{PyS}^{-}$and $6-\mathrm{CH}_{3} \mathrm{PyS} \mathrm{S}^{-}$, but not the metal complexes themselves (Appendix Figure 18). However, the mass spectrum of compound $\mathrm{Ni}(\mathrm{PyS})_{2}\left(6-\mathrm{CH}_{3} \mathrm{PyS}\right)^{-}$has a 9:10 ratio of ligand 6- $\mathrm{CH}_{3} \mathrm{PyS}^{-}$to ligand $\mathrm{PyS} \mathrm{S}^{-}$, while compound $\mathrm{Ni}\left(6-\mathrm{CH}_{3} \mathrm{PyS}\right)_{2}(\mathrm{PyS})^{-}$has $10: 2$ of ligand $6-\mathrm{CH}_{3} \mathrm{PyS}^{-}$to ligand $\mathrm{PyS}$. Ligand dissociation for the electron rich compounds is not unexpected, as this same outcome was noted previously for the homoleptic compound $\mathrm{Ni}\left(6-\mathrm{CH}_{3} \mathrm{PyS}\right)_{3} .^{-208}$ Mass spectroscopy data does not help to support the existence of the electron rich compounds, however it does show that one of the electron poor compounds was made.

For the electron poor compound $\mathrm{Ni}\left(3-\mathrm{CF}_{3} \mathrm{PyS}\right)_{2}(\mathrm{PyS})^{-}$a mass peak is expected at 523.929453 corresponding to $\mathrm{C}_{17} \mathrm{H}_{10} \mathrm{~N}_{3} \mathrm{~S}_{3} \mathrm{~F}_{6} \mathrm{Ni}$. The experimental peak can be seen at 523.87260 (Appendix Figure 18), supporting the formation of this complex. For $\mathrm{Ni}(\mathrm{PyS})_{2}\left(3-\mathrm{CF}_{3} \mathrm{PyS}\right)^{-}$, a peak is expected at 455.942069 , corresponding to $\mathrm{C}_{16} \mathrm{H}_{11} \mathrm{~N}_{3} \mathrm{~S}_{3} \mathrm{~F}_{3} \mathrm{Ni}$. This peak was unfortunately not found. Instead, the peak corresponding to the homoleptic compound $\mathrm{Ni}\left(3-\mathrm{CF}_{3} \mathrm{PyS}\right)_{3}{ }^{-}$can be seen at 591.85272 (computed 591.916837). However the existence of compound $\mathrm{Ni}\left(3-\mathrm{CF}_{3} \mathrm{PyS}\right)_{3}{ }^{-}$in solution is not supported by UV-vis absorption spectroscopy, or experimentally determined reduction potential and $\mathrm{p} K_{a}$ values. It is possible that compound $\mathrm{Ni}\left(3-\mathrm{CF}_{3} \mathrm{PyS}\right)_{3}{ }^{-}$is being formed during the ionization process.

The UV-vis absorption spectra for solutions of $\mathrm{Ni}(\mathrm{PyS})_{2}\left(3-\mathrm{CF}_{3} \mathrm{PyS}\right)^{-}$and $\mathrm{Ni}(3-$ $\left.\mathrm{CF}_{3} \mathrm{PyS}\right)_{2}(\mathrm{PyS})^{-}$in $1: 1 \mathrm{H}_{2} \mathrm{O} / \mathrm{EtOH}$, both under acidic and basic conditions, shows the presence of two unique products when examined in the UV and near UV region. To 
ensure these absorption spectra were not composites of 2:1 ratios of the homoleptic products $\mathrm{Ni}\left(3-\mathrm{CF}_{3} \mathrm{PyS}\right)_{3}{ }^{-}$and $\mathrm{Ni}(\mathrm{PyS})_{3}{ }^{-}$in solution, absorption spectra of $2: 1$ and $1: 2$ $\mathrm{Ni}\left(3-\mathrm{CF}_{3} \mathrm{PyS}\right)_{3}{ }^{-}$and $\mathrm{Ni}(\mathrm{PyS})_{3}{ }^{-}$were acquired under both acidic and basic conditions. These spectra can be seen in Figure 5-7 and Appendix Figure 14 to Appendix Figure 16. From comparison of these spectra we can see that the measured UV-vis absorption spectra of solutions of $\mathrm{Ni}\left(3-\mathrm{CF}_{3} \mathrm{PyS}\right)_{2}(\mathrm{PyS})^{-}$and $\mathrm{Ni}(\mathrm{PyS})_{2}\left(3-\mathrm{CF}_{3} \mathrm{PyS}\right)^{-}$are distinct and are not the same as the absorption spectra of a mixture of the homoleptic complexes. As was the case for $\mathrm{Ni}\left(6-\mathrm{CH}_{3} \mathrm{PyS}\right)_{2}(\mathrm{PyS})^{-}$and $\mathrm{Ni}(\mathrm{PyS})_{2}\left(6-\mathrm{CH}_{3} \mathrm{PyS}\right)^{-}$, experimentally determined $\mathrm{p} K_{a}$ values offer further support for the formation of both $\mathrm{Ni}(\mathrm{PyS})_{2}\left(3-\mathrm{CF}_{3} \mathrm{PyS}\right)^{-}$and $\mathrm{Ni}(3-$ $\left.\mathrm{CF}_{3} \mathrm{PyS}\right)_{2}(\mathrm{PyS})^{-}$. Their experimentally measured $\mathrm{p} K_{a}$ values were determined to be 9.8 and 9.5, with the lower $\mathrm{p} K_{a}$ value corresponding to compound $\mathrm{Ni}\left(6-\mathrm{CH}_{3} \mathrm{PyS}\right)_{2}(\mathrm{PyS})^{-}$ which has two electron poor ligands. This experimental data supports the existence of the heteroleptic compounds in solution, and thus we proceeded to use comparison between experimental and computed data to help us further understand exactly which species are present. We also sought to understand how the presence of so many unique isomers in solution affects how these catalysts function. 


\subsubsection{Effects of isomers on catalytic properties and effectiveness of hydrogen production}

For the initial protonation step, the $\mathrm{p} K_{a}$ values of the three ligand nitrogen atoms are the thermodynamic quantities of interest. Catalyst $\mathrm{Ni}(\mathrm{PyS})_{2}\left(3-\mathrm{CF}_{3} \mathrm{PyS}\right)^{-}$provides an interesting example of the compounding influence of both electronic and structural features of the ligands on these $\mathrm{p} K_{a}$ values. Ligand placement in the central position, such that dechelation occurs at the nitrogen trans to a sulfur, corresponds to a marked decrease in the proton affinity of its nitrogen atom. This is true for all ligands, regardless of electronics (Table 5-2). When examining the acidity of each ligand for the three isomers of $\mathrm{Ni}(\mathrm{PyS})_{2}\left(3-\mathrm{CF}_{3} \mathrm{PyS}\right)^{-}$, this effect can clearly be seen. For $\mathrm{Ni}(\mathrm{PyS})_{2}\left(3-\mathrm{CF}_{3} \mathrm{PyS}\right)^{-}[\mathrm{L}]$, where the withdrawing ligand is positioned on the left, we see that this ligand does not have the lowest $\mathrm{p} K_{a}$ (Figure 5-8). Instead, the unsubstituted ligand in the central position

A

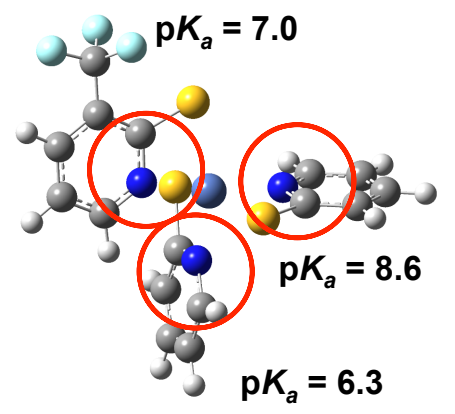

B

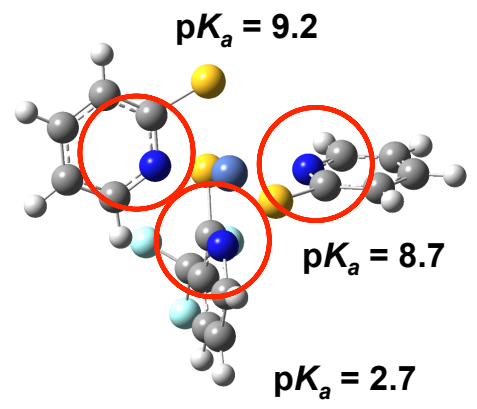

C

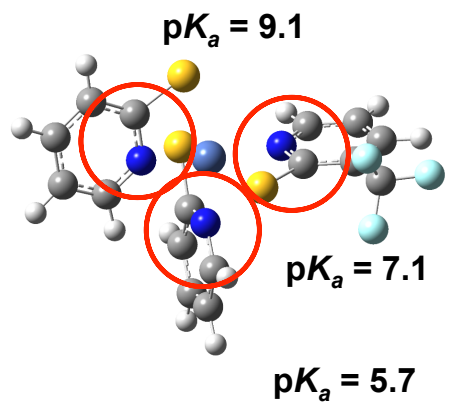

Figure 5-8: A) Optimized structure of $\left.\mathrm{Ni}(\mathrm{PyS})_{2}\left(3-\mathrm{CF}_{3} \mathrm{PyS}\right)^{-}[\mathrm{L}] \mathrm{B}\right) \mathrm{Ni}(\mathrm{PyS})_{2}\left(3-\mathrm{CF}_{3} \mathrm{PyS}\right)^{-}$ [C] and $\mathrm{C}) \mathrm{Ni}(\mathrm{PyS})_{2}\left(3-\mathrm{CF}_{3} \mathrm{PyS}\right)^{-}[\mathrm{R}]$ with three nitrogen protonation sites circled, with corresponding $\mathrm{p} K_{a}$ values beside them. 
is the most acidic, demonstrating that position can override electronics when it comes to influencing $\mathrm{p} K_{a}$ values. For $\mathrm{Ni}(\mathrm{PyS})_{2}\left(3-\mathrm{CF}_{3} \mathrm{PyS}\right)^{-}[\mathrm{C}]$, the withdrawing group is located in the central position and the compounding effect of both position and electronics leads to a staggering decrease in $\mathrm{p} K_{a}$ to 2.7 , relative to 7.0 and 7.1 for the same ligand in the $\mathrm{L}$ and $\mathrm{R}$ positions. The origin of the substantial effect of position on the acidity of ligand nitrogens is currently under investigation. It would be advantageous to be able to structurally force ligands into a select position so as to further tune the effects of ligands through positioning modification in addition to electronic modification. The implication for catalysis of this phenomenon is that without proper control over which isomer is formed during synthesis, effectiveness could be greatly diminished, or at the very least, experimental investigation of catalytic mechanisms is markedly more complex. 

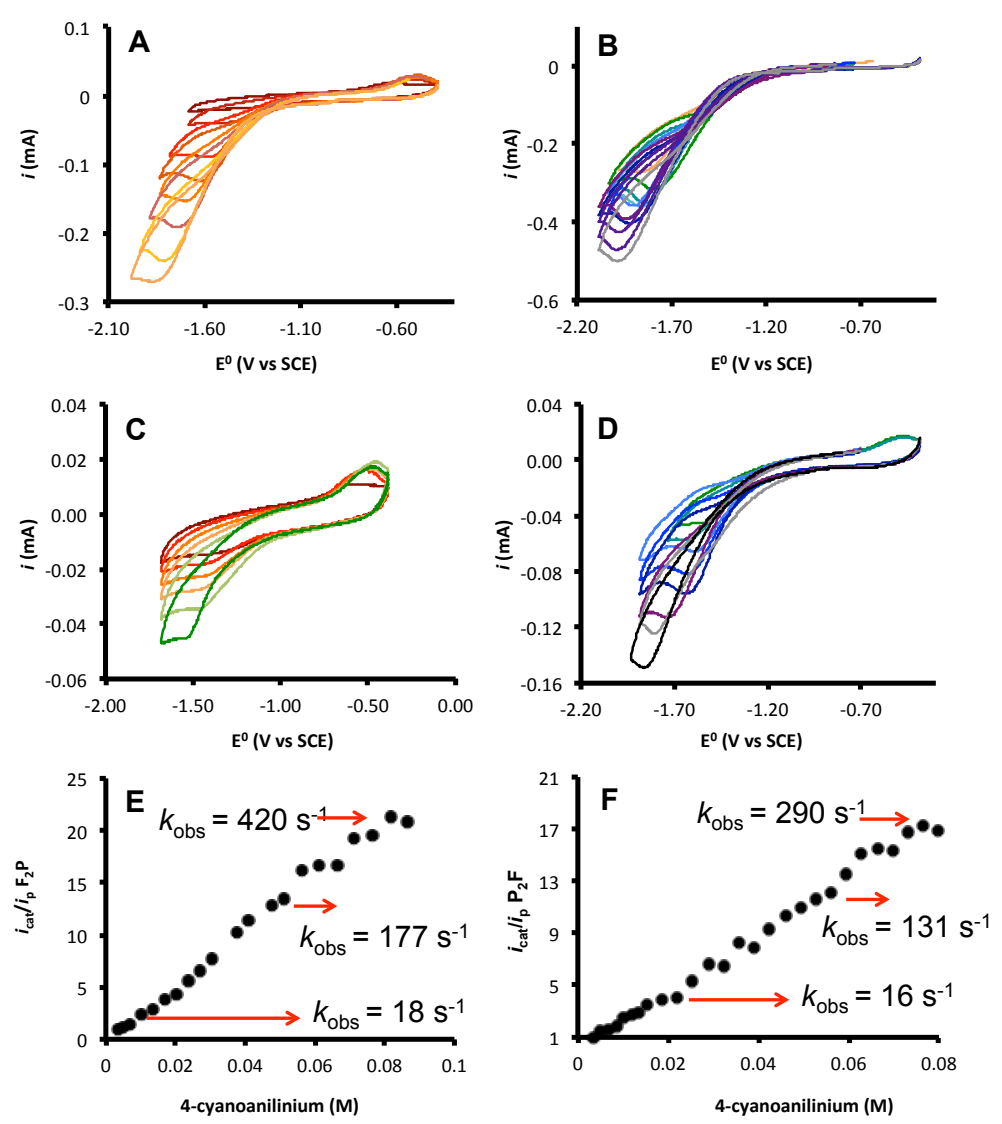

Figure 5-9: A) Cyclic voltammograms of $\mathrm{Ni}\left(6-\mathrm{CH}_{3} \mathrm{PyS}\right)_{2}(\mathrm{PyS})^{-}$with increasing concentration of 4-cyanoanilinium and increasing potential up to $0.1 \mathrm{M}$ 4cyanoanilinium showing a change in catalytic zone B) continuation of A with additional acid and larger potential sweep, showing a continued change in catalytic zone C) cyclic voltammograms of $\mathrm{Ni}(\mathrm{PyS})_{2}\left(6-\mathrm{CH}_{3} \mathrm{PyS}\right)^{-}$with increasing concentration of 4cyanoanilinium up to $0.03 \mathrm{M} 4$-cyanoanilinium $\mathrm{D}$ ) continuation of $\mathrm{B}$ with additional acid and applied potential, showing a continued change in catalytic zone E) plot of $i_{\text {cat }} / i_{\mathrm{p}}$ for $\left.\mathrm{Ni}\left(6-\mathrm{CH}_{3} \mathrm{PyS}\right)_{2}(\mathrm{PyS})^{-}\right)$plot of $i_{\text {cat }} / i_{\mathrm{p}}$ for $\mathrm{Ni}(\mathrm{PyS})_{2}\left(6-\mathrm{CH}_{3} \mathrm{PyS}\right)^{-}$.

Electrochemical investigation was undertaken to gain a better understanding of how the existence of multiple isomers affects the reduction potentials and rates of hydrogen production. In order to observe the catalytic response of different isomers at lower overpotentials, the initial sweep window was decreased from $-0.5 \mathrm{~V}$ to $-2.0 \mathrm{~V}$ vs 
SCE to $-0.5 \mathrm{~V}$ to $-1.60 \mathrm{~V}$ vs $\mathrm{SCE}$. For example, for $\mathrm{Ni}(\mathrm{PyS})_{2}\left(6-\mathrm{CH}_{3} \mathrm{PyS}\right)^{-}$, an initial potential sweep to $-1.60 \mathrm{~V}$ vs SCE results in a first redox event at $-1.45 \mathrm{~V}$ vs SCE. Comparison to computationally generated redox potential supports the assignment of this peak to the $\mathrm{Ni}(\mathrm{II}) \mathrm{H} / \mathrm{Ni}(\mathrm{I}) \mathrm{H}$ couple of six of the possible nine isomers of $\mathrm{Ni}(\mathrm{PyS})_{2}(6-$ $\mathrm{CH}_{3} \mathrm{PyS}$ )H (Table 5-4). From the shape of the $\mathrm{CV}$ trace, it appears catalysis is occurring in zone KS, indicating the presence of side reactions or depletion of the acid. Subsequent addition of acid does push catalysis closer to pure kinetic conditions, or zone K (Figure 5-9A). The remaining three isomers have higher overpotentials for the $\mathrm{Ni}(\mathrm{II}) \mathrm{H} / \mathrm{Ni}(\mathrm{I}) \mathrm{H}$ redox. These calculated values range from -1.67 to $-1.70 \mathrm{~V}$ vs SCE, thus the potential sweep was increased to $-1.85 \mathrm{~V}$ vs SCE to see if a second current response could be identified (Figure 5-9B). It is apparent from the shape of the CV trace that once the potential is increased, catalysis immediately reverts back to zone KS. We propose that this is due to an increased concentration of active catalyst in solution, causing hydrogen production to become dependent on substrate diffusion to the electrode once again. As the concentration of acid is increased, the data shows a second shift back towards zone K, indicating that pure kinetic conditions have been reached again. This switch in catalytic zones supports the existence of multiple distinct isomers of $\mathrm{Ni}(\mathrm{PyS})_{2}\left(6-\mathrm{CH}_{3} \mathrm{PyS}\right)^{-}$in solution as it demonstrates that under more negative potential, more species become active for hydrogen production. As would be expected, the rate of hydrogen production varies depending on the number of active catalyst in solution. The initial $k_{\mathrm{obs}}$ for $\mathrm{Ni}(\mathrm{PyS})_{2}\left(6-\mathrm{CH}_{3} \mathrm{PyS}\right)^{-}$is quite poor, at $18 \mathrm{~s}^{-1}$ (Figure 5-9E). When the applied potential 
and acid concentration is increased, this value jumps significantly to $420 \mathrm{~s}^{-1}$ (Figure 5-9E). The implications of these results for catalysis are that without control over the formation of selected isomers, catalysis can be limited by higher required overpotentials.

The same method was applied to understand the hydrogen production rates of the other electron rich compound $\mathrm{Ni}\left(6-\mathrm{CH}_{3} \mathrm{PyS}\right)_{2}(\mathrm{PyS})^{-}$(Figure 5-9C,D). No reduction peak is observed for this catalyst in the absence of acid when the potential is swept to $-1.65 \mathrm{~V}$ vs SCE. Following the first addition of acid, a reduction peak is observed at a potential of $-1.55 \mathrm{~V}$ vs SCE, the same potential that was measured when $-2.0 \mathrm{~V}$ vs SCE was applied (Figure 5-9C). The computed redox potentials for the first electrochemical step for four of the nine isomers of $\mathrm{Ni}\left(6-\mathrm{CH}_{3} \mathrm{PyS}\right)_{2}(\mathrm{PyS})^{-} \mathrm{H}$ fall within the margin of error to be reduced at this potential. As zone $\mathrm{K}$ is approached, a low rate of hydrogen production of $16 \mathrm{~s}^{-1}$ is measured, suggesting a low concentration of active catalyst in solution or poor catalyst performance. A low concentration of active catalyst makes sense given our computational findings. When the applied potential is swept furthr and concentration of acid is increased further the CV traces revert back to zone $\mathrm{KS}$ as seen in Figure 5-9D, likely this is due to the increased concentration of active catalyst in solution causing hydrogen production to become dependent on the concentration of acid once again. Further addition of acid pushes catalysis back into zone $\mathrm{K}$ and the measured rate increases to $131 \mathrm{~s}^{-1}$. We propose that this is once again due to the effective concentration of active catalyst increasing in solution as experimental conditions enable more isomers of $\mathrm{Ni}\left(6-\mathrm{CH}_{3} \mathrm{PyS}\right)_{2}(\mathrm{PyS})^{-}$to be reduced. Increases in the current response of $\mathrm{Ni}(6-$ 
$\left.\mathrm{CH}_{3} \mathrm{PyS}\right)_{2}(\mathrm{PyS})^{-}$can be seen in the plot of $i_{\text {cat }} / i_{\mathrm{p}}$. We hypothesize, based on computational data, that each increase in current corresponds with the reduction of additional isomers (Figure 5-9F). It is likely that additional mechanisms would also become accessible with an increase in both applied potential and concentration of acid. For example, isomers that can undergo second protonation at a ligand nitrogen cannot be reduced when the potential is swept out to $-1.65 \mathrm{~V}$ vs SCE. However, once the potential is swept to $-2.0 \mathrm{~V}$ vs SCE, reduction of these intermediates becomes a thermodynamically viable mechanism. The hydrogen production rate was further increased to $290 \mathrm{~s}^{-1}$ through continued addition of acid.

Poor hydrogen production by can also be understood by using computational data to interpret experimental results. Compound $\mathrm{Ni}\left(3-\mathrm{CF}_{3} \mathrm{PyS}\right)_{2}(\mathrm{PyS})^{-}$has a low measured rate of hydrogen production, and analysis of this catalyst provides an informative example. Experimental UV-vis absorption data indicates that $\mathrm{Ni}\left(3-\mathrm{CF}_{3} \mathrm{PyS}\right)_{2}(\mathrm{PyS})^{-}$has a
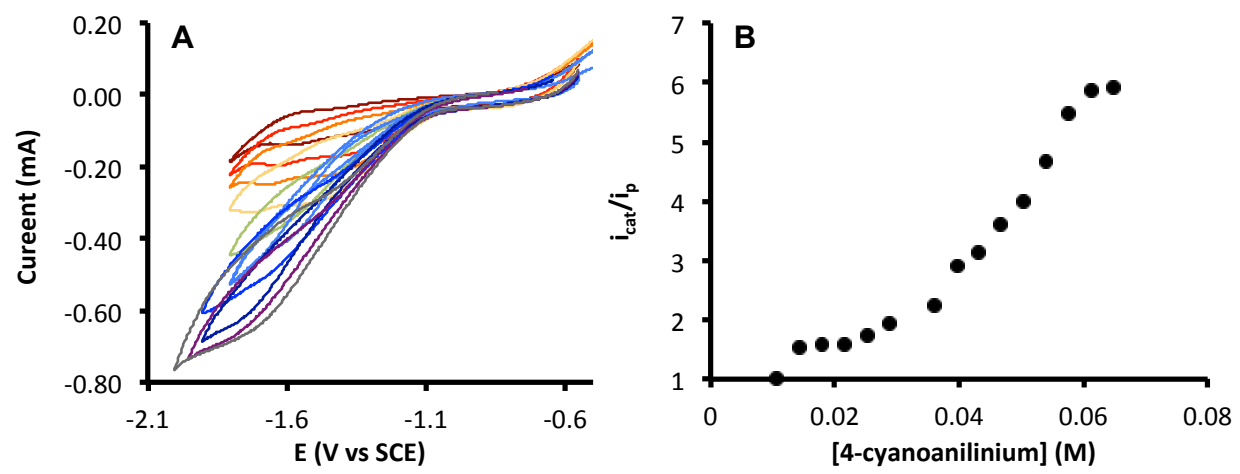

Figure 5-10: A) Cyclic voltammetry traces for $\mathrm{Ni}\left(3-\mathrm{CF}_{3} \mathrm{PyS}\right)_{2}(\mathrm{PyS})^{-}$with increasing additions of 4-cyanoanilinium up to $0.065 \mathrm{M}$ and B) plot of $i_{\text {cat }} / i_{p}$ vs [4-cyanoanilinium]. 
$p K_{a}$ of 9.5 and electrochemical data indicates the presence of two redox events within a potential window of $-1.80 \mathrm{~V}$ vs SCE, one taking place at $-1.52 \mathrm{~V}$ vs SCE and the other at -1.94 V vs SCE (Figure 5-10 and Appendix Figure 14). According to computational data, the measured $p K_{a}$ can be attributed to the protonation of the unsubstituted ligand on both $\mathrm{Ni}\left(3-\mathrm{CF}_{3} \mathrm{PyS}\right)_{2}(\mathrm{PyS})^{-}[\mathrm{L}]$ and $\mathrm{Ni}\left(3-\mathrm{CF}_{3} \mathrm{PyS}\right)_{2}(\mathrm{PyS})^{-}[\mathrm{R}]$. These two protonation sites have calculated $\mathrm{p} K_{a}$ values of 8.80 and 8.40 , respectively (Table 5-2). The unsubstituted ligand of $\mathrm{Ni}\left(3-\mathrm{CF}_{3} \mathrm{PyS}\right)_{2}(\mathrm{PyS})^{-}[\mathrm{C}]$ is not a favored protonation site. Due to its central positioning, it has a computed $\mathrm{p} K_{a}$ value of 5.20 . The low $\mathrm{p} K_{a}$ of $\mathrm{Ni}\left(3-\mathrm{CF}_{3} \mathrm{PyS}\right)_{2}(\mathrm{PyS})^{-[C]}$ is a detrimental for hydrogen production, as the first step in the catalytic cycle protonation (Table 5-2). As noted previously, computed energies of formation indicate that $\mathrm{Ni}\left(3-\mathrm{CF}_{3} \mathrm{PyS}\right)_{2}(\mathrm{PyS})^{-}[\mathrm{C}]$ is the most stable isomer of $\left(3-\mathrm{CF}_{3} \mathrm{PyS}\right)_{2}(\mathrm{PyS})^{-}$. Because of its greater stability relative to $\mathrm{Ni}\left(3-\mathrm{CF}_{3} \mathrm{PyS}\right)_{2}(\mathrm{PyS})^{-}[\mathrm{L}]$ and $\left.\mathrm{Ni}\left(3-\mathrm{CF}_{3} \mathrm{PyS}\right)_{2}(\mathrm{PyS})^{-[\mathrm{R}}\right]$, $\mathrm{Ni}\left(3-\mathrm{CF}_{3} \mathrm{PyS}\right)_{2}(\mathrm{PyS})[\mathrm{C}]$ likely exists in larger proportion, meaning the concentration of active catalyst is diminished under neutral conditions (Table 5-1). Additionally, due to dechelation of the ligands along the catalytic cycle, isomerization to lower energy configurations could occur. Thus, as hydrogen production proceeds for $\mathrm{Ni}(3-$ $\left.\mathrm{CF}_{3} \mathrm{PyS}\right)_{2}(\mathrm{PyS})^{-}[\mathrm{L}]$ and $\left.\mathrm{Ni}\left(3-\mathrm{CF}_{3} \mathrm{PyS}\right)_{2}(\mathrm{PyS})^{-[\mathrm{R}}\right]$, isomerization to $\mathrm{Ni}\left(3-\mathrm{CF}_{3} \mathrm{PyS}\right)_{2}(\mathrm{PyS})^{-}$ [C] could further decreasing the concentration of active catalyst in solution, resulting in the low rate of hydrogen production. 
Additionally, $\mathrm{Ni}\left(3-\mathrm{CF}_{3} \mathrm{PyS}\right)_{2}(\mathrm{PyS})^{-}[\mathrm{L}]$ and $\mathrm{Ni}\left(3-\mathrm{CF}_{3} \mathrm{PyS}\right)_{2}(\mathrm{PyS})^{-}[\mathrm{R}]$ are severely limited because they require a large overpotential for the final reduction step. $\mathrm{Ni}(3-$ $\left.\mathrm{CF}_{3} \mathrm{PyS}\right)_{2}(\mathrm{PyS})^{-}[\mathrm{L}]$ and $\mathrm{Ni}\left(3-\mathrm{CF}_{3} \mathrm{PyS}\right)_{2}(\mathrm{PyS})^{-}[\mathrm{R}]$ have initial computed $\mathrm{E}^{0}$ values of 1.53 and $-1.54 \mathrm{~V}$ vs SCE. For the first reduction step, it is interesting to note that both of these redox values for the first step are lower than for the unsubstituted $\mathrm{Ni}(\mathrm{PyS})_{3}$, demonstrating that even for heteroleptic compounds, the electronic effects of the ligands are as expected when the mechanism remains unchanged. However, following this reduction, protonation is possible for both compounds at a second ligand nitrogen. $\mathrm{Ni}(3-$ $\left.\mathrm{CF}_{3} \mathrm{PyS}\right)_{2}(\mathrm{PyS})^{-}[\mathrm{L}] \mathrm{N}^{\mathrm{L}} \mathrm{N}^{\mathrm{C}}$ has a $p K_{a}$ of 11.51 while $\mathrm{Ni}\left(3-\mathrm{CF}_{3} \mathrm{PyS}\right)_{2}(\mathrm{PyS})^{-}[\mathrm{R}] \mathrm{N}^{\mathrm{R}} \mathrm{N}^{\mathrm{C}}$ has a $\mathrm{p} K_{a}$ of 12.11. The subsequent redox events for both compounds are calculated to require
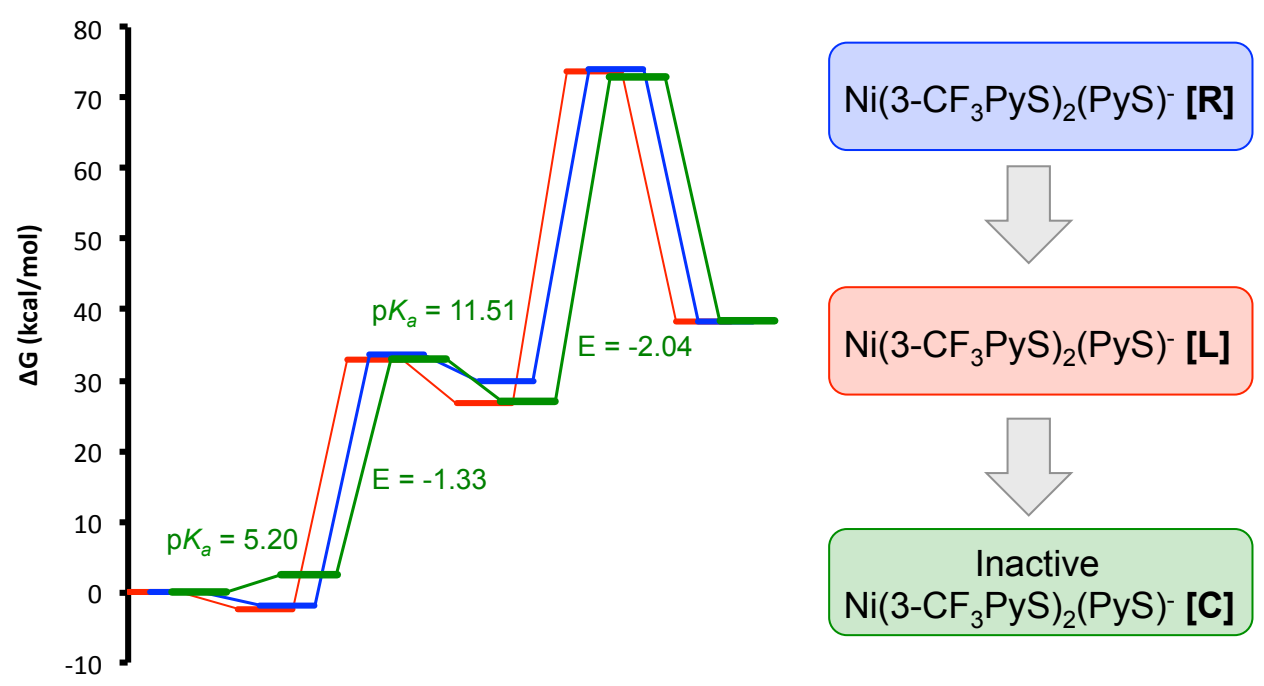

Figure 5-11: Reaction coordinates for the three isomers of $\mathrm{Ni}\left(3-\mathrm{CF}_{3} \mathrm{PyS}\right)_{2}(\mathrm{PyS})^{-}$ highlighting numerical thermodynamic values for each protonation and reduction of $\mathrm{Ni}\left(3-\mathrm{CF}_{3} \mathrm{PyS}\right)_{2}(\mathrm{PyS})^{-}[\mathrm{C}]$. Relative energies of formation for each of the three isomers are depicted on the right, with $\mathrm{Ni}\left(3-\mathrm{CF}_{3} \mathrm{PyS}\right)_{2}(\mathrm{PyS})^{-}[\mathrm{R}]$ being the least stable and $\mathrm{Ni}(3-$ $\left.\mathrm{CF}_{3} \mathrm{PyS}\right)_{2}(\mathrm{PyS})^{-}[\mathrm{C}]$ being the most stable. 
more than $-2.0 \mathrm{~V}$ vs SCE. Reduction of the compounds protonated at their metal centers is only calculated to require -1.13 and $-1.15 \mathrm{~V}$ vs SCE, respectively. However, these low reduction potentials are not observed experimentally. This may be due to the low $\mathrm{p} K_{a}$ value for direct protonation at the metal center and the absence of any proton-coupled transition steps that would result in a hydrogen being on the metal center. When up to 2.0 V vs SCE of potential is applied, a catalytic current is observed, though it rapidly plateaus (Figure 5-10). We propose that the limited effectiveness of compound Ni(3$\left.\mathrm{CF}_{3} \mathrm{PyS}\right)_{2}(\mathrm{PyS})^{-}$is a result of variable proton affinities for each isomer, resulting in a low concentration of active catalyst. Additionally, large required overpotentials along the catalytic cycle may also be contributing to the low overpotential. Ultimately, this catalyst rapidly ceases to produce hydrogen and it is possible that this is due to its conversion to the inactive $\mathrm{Ni}\left(3-\mathrm{CF}_{3} \mathrm{PyS}\right)_{2}(\mathrm{PyS})^{-}[\mathrm{C}]$ isomer.

Another indication that isomerization along the catalytic cycle affects hydrogen production rates is provided through a comparison of the rates of hydrogen production under extreme experimental conditions. If the conversion of isomers throughout the catalytic cycle causes a decrease in the effectiveness of hydrogen production, then the use of a high initial concentration of acid and a high initial overpotential should result in a faster rate of hydrogen production. The concentration of active catalyst in solution should be maximized prior to isomerization. An initial CV scan was taken of catalyst solutions with a concentration of $5.4 \times 10^{-3} \mathrm{M}$ 4-cyanoanilinium, and an applied potential window of $-0.5 \mathrm{~V} \mathrm{SCE}$ to $-2.0 \mathrm{~V}$ vs SCE to establish a clear $i_{p}$ value. A subsequent scan with a 4- 
cyanoanilinium concentration of $2.2 \times 10^{-2} \mathrm{M}$ was then run within a potential window of $0.5 \mathrm{~V}$ vs SCE to $-2.0 \mathrm{~V}$ vs SCE (Appendix Figure 17). Under these initial conditions, the majority of the catalyst in solution should be active and results should provide a more accurate comparison of hydrogen production rates between the four heteroleptic compounds. The observed rate constants for $\mathrm{Ni}\left(3-\mathrm{CF}_{3} \mathrm{PyS}\right)_{2}(\mathrm{PyS})^{-}, \mathrm{Ni}(\mathrm{PyS})_{2}\left(3-\mathrm{CF}_{3} \mathrm{PyS}\right)^{-}$, $\mathrm{Ni}(\mathrm{PyS})_{2}\left(6-\mathrm{CH}_{3} \mathrm{PyS}\right)^{-}$and $\mathrm{Ni}\left(6-\mathrm{CH}_{3} \mathrm{PyS}\right)_{2}(\mathrm{PyS})^{-}$were found to be 3218, 2077, 3275 and $4392 \mathrm{~s}^{-1}$ respectively. When the concentration of 4-cyanoanilinium was gradually increased along with the applied potential, the relative rates of reaction for $\mathrm{Ni}(3-$ $\left.\mathrm{CF}_{3} \mathrm{PyS}\right)_{2}(\mathrm{PyS})^{-}, \mathrm{Ni}(\mathrm{PyS})_{2}\left(3-\mathrm{CF}_{3} \mathrm{PyS}\right)^{-}, \mathrm{Ni}(\mathrm{PyS})_{2}\left(6-\mathrm{CH}_{3} \mathrm{PyS}\right)^{-}$and $\mathrm{Ni}\left(6-\mathrm{CH}_{3} \mathrm{PyS}\right)_{2}(\mathrm{PyS})^{-}$ were found to be $35,99,290$ and $420 \mathrm{~s}^{-1}$. The measured rates of hydrogen production are 1-2 orders of magnitude larger for the high acid, high potential conditions. Although decomposition of the catalyst is possible, these results support the hypothesis that interconversion of isomers along the catalytic cycle reduces the concentration of active catalyst in solution. Thus, the overall effectiveness of certain heteroleptic compounds is severely limited and we once again see the importance of structurally favoring the formation of more active isomers.

\subsection{Conclusions}

In summary, we have found that although we can make fairly accurate predictions about general trends in the physical properties of heteroleptic catalysts, the varied effects on hydrogen production efficiency of adding electron donating and withdrawing substituents in a non-uniform way are much more difficult to predict. The experimentally 
measured properties of each catalyst follow the trends we would expect, but physical properties alone do not provide enough information about the intricacies of the catalytic process, which ultimately allow us to improve catalyst structure. However, discrepancies in hydrogen production rates can be understood in a more detailed way as a consequence of how the concentration of active catalyst is impacted by the existence of many isomers of the same compound. Because each isomer has unique physical properties, the effective concentration of active catalyst in solution depends on experimental conditions, thus causing large fluctuations in measured rates of hydrogen production. From our investigation of both experimental and computational data for the four heteroleptic compounds studied herein, we see that in addition to electronics, the placement of ligands has an enormous impact on the properties of each isomer, particularly the $\mathrm{p} K_{a}$ values. This discovery will guide the design of future catalysts by providing evidence that the placement of ligands in the most strategic position is just as important as modification of the electronics of the ligands themselves. In the case of $\mathrm{Ni}(\mathrm{PyS})_{3}{ }^{-}$derivatives, placing an electron rich ligand in the central position can negate the effects of having increased electron density, by greatly reducing the proton affinity of that particular ligand. Because heteroleptic compounds can isomerize during catalysis, creating structural features that force the formation and maintenance of a particular isomer would be a very powerful tool in the creation of improved catalysts for many areas of chemistry, not limited to proton reduction. The use of a 4-coordinate ligand to maintain geometry may be one such way to allow catalysis to occur, while simultaneously imparting a measure of control over the 
mechanism through which that catalysis occurs. Additionally, understanding why the structure of heteroleptic compounds results in such drastically different properties from one ligand to another for each isomer is of the utmost importance. Current computational investigation is underway in our lab to explain the nature of these highly variable properties as well as to uncover strategies to target the synthesis particularly active isomers. It is our hypothesis that by selectively favoring the synthesis of only the most active heteroleptic catalysts, the effectiveness of catalysis could be greatly improved. 
CHAPTER 6

PHOTOCHEMICAL CONVERSION OF SOLAR ENERGY

Photocatalytic Water Reduction Using a Polymer Coated Carbon Quantum Dot

\section{Sensitizer and a Nickel Nanoparticle Catalyst}

This work has been published in IOP Nanotechnology. ${ }^{211}$

Virca, C.; Winter, H.; Goforth, A. M.; Mackiewicz, M.; McCormick, T.

Photocatalytic Water Reduction Using a Polymer Coated Carbon Quantum Dot Sensitizer and a Nickel Nanoparticle Catalyst. Nanotechnology 2017, 28.

\subsection{Introduction}

Solar driven water splitting ${ }^{3,153,212}$ has been studied as a method to store energy since Fujishima and Hondas's first $\mathrm{H}_{2}$ producing electrochemical photolysis experiments in $1972 .{ }^{55}$ Although significant progress has been made in the last few decades in the area of photochemical water splitting to improve the effectiveness of both catalysts ${ }^{61,75,157,213-}$ 215 and sensitizers, ${ }^{102,117,213}$ the development of benign, easily-synthesized, and inexpensive photosensitizers and catalysts remains of interest. ${ }^{53,57,92,216-221}$ To date, one of the most successful sensitizers, published by Eisenberg and co-workers, is CdSe quantum dots. ${ }^{63,155}$ Other photocatalyzed energy storage reactions can also be effectively sensitized through the use of quantum dots, ${ }^{222-225}$ such as using dual-sized CdTe quantum dot sensitizers to enhance photo-electrochemical water oxidation. ${ }^{226}$ However, despite the 
effectiveness of CdSe and CdTe quantum dot sensitizers, commercialization is limited due to toxicity. ${ }^{227}$ Consequently, the discovery, study, and use of more benign sensitizers are of significant interest.

Recent reports on the wide range of excitation and emission energies of carbon quantum dots (CQDs) suggest they may be suitable light absorbers for photochemical water splitting. ${ }^{113,114,117,118,228,229}$ Reisner and co-workers report $\mathrm{H}_{2}$ production from a system using a CQD sensitizer and a nickel-bis-diphosphine (Ni-P2N2) catalyst irradiated with UV-light. ${ }^{65}$ The luminescence quantum yield of the CQDs in this study was relatively low (2.3\% at $360 \mathrm{~nm}$ excitation). Polymer coatings have been shown to improve the emission quantum yields of CQDs; for example, a polyethylene glycol (PEG) coating on CQDs can increase fluorescence quantum yields by $100 \% .{ }^{120}$ The fluorescence of CQDs is attributed to surface defects, thus polymer passivation is thought to decrease non-radiative decay pathways, enhancing fluorescence quantum yields. ${ }^{12,230}$ We hypothesized that applying a PVP coating to CQDs would reduce non-radiative recombination and increase the probability of electron transfer from the sensitizer to a catalyst, thus increasing $\mathrm{H}_{2}$ production. PVP is selected for use in this study as it provides the added benefit of solubilizing the nanomaterials and has been applied in literature for this purpose. ${ }^{231}$ Furthermore, PVP coating on CQDs has been shown to both enhance fluorescence, similar to a PEG coating, but to have a less electronically insulating effect. $^{232}$ 
Recently, nickel nanoparticles (NiNPs) were shown to catalyze $\mathrm{H}_{2}$ production. ${ }^{151,231}$ When sensitized with 2-phenyl-4-(1-naphthyl)quinolinium, the rate of $\mathrm{H}_{2}$ production using a NiNP catalyst was $40 \%$ of that of an analogous system catalyzed by platinum nanoparticles (PtNPs) ${ }^{231} \mathrm{H}_{2}$ production in water required that the NiNPs be solubilized using a polyvinylpyrrolidone (PVP) coating. ${ }^{231}$ Thus, we chose PVP to stabilize and solubilize both the CQD sensitizer and the NiNP catalyst.

Herein, we report the effect of the amount of PVP on $\mathrm{H}_{2}$ production using CQDs as sensitizers and a NiNP catalyst, when irradiated with visible light $(470 \mathrm{~nm})$ (Figure 6-1). ${ }^{211}$ Specifically, the photophysical properties of PVP-coated CQDs are investigated and correlated to $\mathrm{H}_{2}$ production. The PVP coating of the CQD sensitizer was found to both increase CQD fluorescence quantum yields and affect $\mathrm{H}_{2}$ production. A 1:1 water/EtOH solution containing CQDs, PVP-coated NiNPs, and

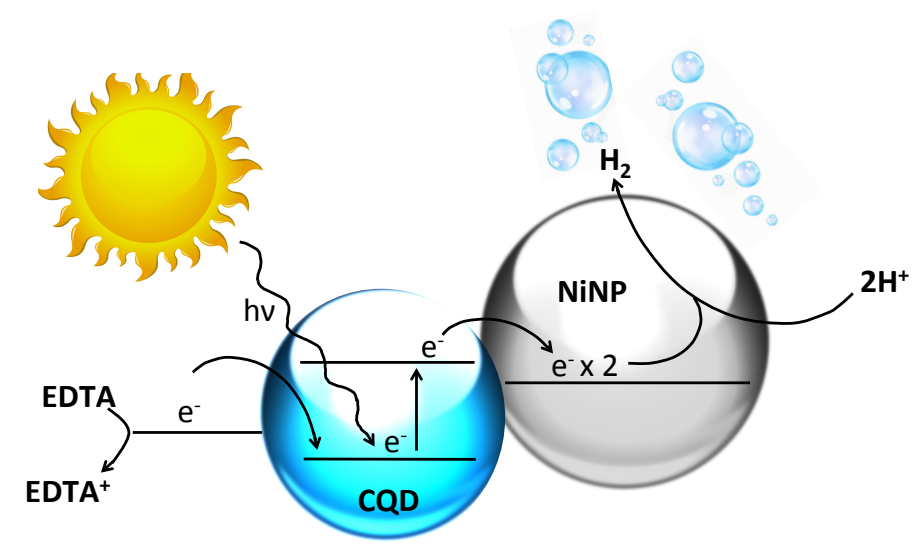

Figure 6-1: Schematic representation of electron movement through the CQD/NiNP $\mathrm{H}_{2}$ production system . 
ethylenediaminetetraacetic acid (EDTA) as the sacrificial electron donor, produced $\mathrm{H}_{2}$ gas when irradiated with light at $470 \mathrm{~nm}$. Both the catalyst and photosensitizer were functional without additional purification beyond wash/spinning centrifuge cycles, eliminating the need for additional tedious purification of the NiNPs and CQDs. Characterization of the nanomaterials and the role of PVP is described in detail below.

\subsection{Methods}

\subsubsection{Potassium Ferrioxalate Actinometry ${ }^{146}$}

All manipulations were performed in a dark room with a red light source until the experimental light source $(470 \mathrm{~nm})$ was measured. A solution of $0.15 \mathrm{M}$ $\mathrm{K}_{3} \mathrm{Fe}\left(\mathrm{C}_{2} \mathrm{O}_{4}\right)_{3} \cdot \mathrm{H}_{2} \mathrm{O}$ was prepared by dissolving $73.68 \mathrm{~g}$ of solid into $800 \mathrm{~mL}$ of water with $100 \mathrm{~mL}$ of $1 N$ sulphuric acid. This solution was brought to a total volume of $1 \mathrm{~L}$.

A calibration graph was then prepared from three standard solutions: 1) a $0.4 \times 10^{-6} \mathrm{M}$ solution of $\mathrm{Fe}^{2+}$ in sulphuric acid, 2) a $0.1 \%$ by weight solution of 1,10 phenanthroline in water and 3) a buffer solution of $600 \mathrm{~mL}$ of $\mathrm{H}_{3} \mathrm{CCOONa}$ and $360 \mathrm{~mL}$ of $1 N$ sulphuric acid diluted to a final volume of $1 \mathrm{~L}$. A series of standard solutions of total volume $10 \mathrm{~mL}$ was made in $25 \mathrm{~mL}$ volumetric flasks using $0,0.5,1,1.5,2.0,2.5$, 3.0, 3.5, 4.0, 4.5, $5.0 \mathrm{~mL}$ of standard solution 1 and sulphuric acid. $2 \mathrm{~mL}$ of solution 2 was then added to each $10 \mathrm{~mL}$ solution and a sufficient amount of solution 3 was added to reach the final volume of $10 \mathrm{~mL}$. These standard solutions were allowed to react for an hour in the dark. The absorption of each of these solutions was then measured at $510 \mathrm{~nm}$ 
using the iron-free solution as a blank. A linear plot of Io/I vs. molar concentration of $\mathrm{Fe}^{2+}$ phenanthroline complex was then generated.

The intensity of the $470 \mathrm{~nm}$ light source was then determined. In order to do this $30 \mathrm{~mL}$ of actinometer solution was irradiated under inert atmosphere for 10, 20 and 40 minutes. Next, $10 \mathrm{~mL}$ of solution was taken and $2 \mathrm{~mL}$ of phenanthroline solution was added along with $5 \mathrm{~mL}$ of buffer solution into a $25 \mathrm{~mL}$ volumetric flask. The volume was filled with water. Following $1 \mathrm{~h}$, the absorption was measured at $510 \mathrm{~nm}$. The number of photons was calculated using the following formula:

$$
n_{\mathrm{Fe}^{2+}}=\frac{6.023 \times 10^{20} \mathrm{~V}_{1} \mathrm{~V}_{3} \log _{10}\left(\mathrm{I}_{0} / \mathrm{I}\right)}{\mathrm{V}_{2} l \varepsilon}
$$

$\mathrm{V}_{1}=$ volume of irradiated actinometer solution

$\mathrm{V}_{2}=$ volume taken for light measurement

$\mathrm{V}_{3}=$ final diluted volume of $\mathrm{V}_{2}$

$\log _{10}\left(\mathrm{I}_{0} / \mathrm{I}\right)=$ measured optical density

$l=$ path length

$\varepsilon=$ molar extinction coefficient of $\mathrm{Fe}^{2+}$ complex (can be determined experimentally)- approximately $1.11 \times 10^{4} 1 \mathrm{~mol}^{-1} \mathrm{~cm}^{-1}$

The number of photons was determined using the following equation:

$$
n_{\mathrm{a}}=\frac{n_{\mathrm{Fe}^{2+}}}{\phi_{\lambda}}
$$

Where $\phi_{\lambda}$ is the quantum yield for $\mathrm{Fe}^{2+}$ formation at a given wavelength (in this case, 0.94). Dividing by $t$ (irradiation time in seconds) yields the number of photons absorbed by the actinometer per second. 
The quantum efficiency of $\mathrm{H}_{2}$ production was determined next, using the known amount of photons as calculated above and the measured $\mathrm{H}_{2}$ production:

$2.55 \times 10^{14}$ photons/s as measured above $1.596 \times 10^{17}$ photons/10 mins

$2.78 \mu$ mols $\mathrm{H}_{2} / 10$ mins measured as described in the manuscript

$$
\begin{gathered}
1.675 \times 10^{18} \mathrm{H} \text { atoms consumed } / 10 \text { mins } \\
\mathrm{A}_{\mathrm{Fe}^{3+}}=0.061553 \\
\mathrm{~A}_{\mathrm{CQD}}=0.00035 \\
\frac{\mathrm{A}_{\mathrm{Fe}^{3+}}}{\mathrm{A}_{\mathrm{CQD}}} \times \frac{1.596 \times 10^{17} \text { photons }}{10 \text { mins }}=\frac{2.8 \times 10^{19} \text { photons }}{10 \text { mins }} \\
\frac{1.675 \times 10^{18} \mathrm{H} \text { atoms }}{2.8 \times 10^{19} \text { photons }}=0.0597=5.97 \% \\
\mathrm{~A}=\text { absorbance of the compound }
\end{gathered}
$$

\section{Results and Discussion}

NiNPs were synthesized via thermolysis of nickel acetylacetonate $\left(\mathrm{Ni}(\mathrm{Acac})_{2}\right)$ in the presence of trioctylphosphine (TOP) and oleylamine according to a previously published method. ${ }^{151}$ The relatively short growth time and excess stabilizing TOP results in highly monodisperse NiNPs with an average diameter of $6 \mathrm{~nm}$ (TEM imagine in Figure 6-2A, DLS data in Appendix Figure 19. Exchanging the coating for 29K MW PVP makes the NPs dispersible in water. DLS data of the aqueous, PVP-coated NiNPs shows that the particles aggregate into polydispersed microstructures $c a .3 \mu \mathrm{m}$ in size (Appendix Figure 20). By TEM, CQDs around $5 \mathrm{~nm}$ in size were observed, and for certain small, well-resolved particles crystalline lattice fringes are visible that resemble 
those attributed to graphitic carbon in the literature (Figure 6-2B). ${ }^{65,118}$ Differing amounts of PVP were added to the CQDs as a weight percent of the CQD in solution.

\subsubsection{CQD Composition and Morphology.}

CQDs were synthesized through thermolysis of citric acid at $180^{\circ} \mathrm{C}$ for 24 hours. The formation of CQDs was monitored using ${ }^{1} \mathrm{H}$ and ${ }^{13} \mathrm{C}$ NMR. Citric acid was consumed almost entirely within 5 hours of heating; primarily aromatic, olefinic and aliphatic protons became apparent in ${ }^{1} \mathrm{H}$ NMR (S1). After 24 hours some olefinic protons are no longer visible in ${ }^{1} \mathrm{H}$ NMR (Appendix Figure 21) and the ${ }^{13} \mathrm{C}$ NMR spectrum
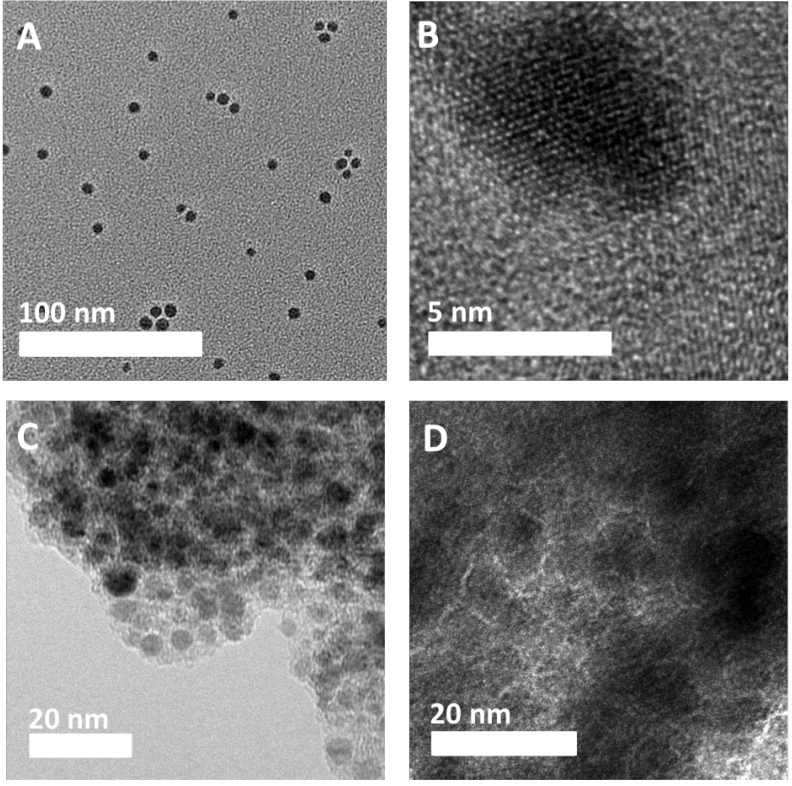

Figure 6-2: TEM images of $A$ ) as synthesized NiNPs showing consistent size distribution (size distribution in S5) B) CQD showing crystal-lattice fringes C) PVPcoated NiNPs and CQDs D) reaction mixture after irradiation. 
indicates the presence of aromatic, olefinic, nitrile and aliphatic carbon as well as possibly ketones, aldehydes, carboxylic acids and esters (Appendix Figure 22). These findings suggest that the emissive properties of the CQDs could be due to isolated pockets of aromatic carbon surrounded by aliphatic carbon regions in addition to quantum confinement effects as suggested previously. ${ }^{228}$ Minimally, NMR analysis indicates the CQDs are not pure "nano-graphene". The FT-IR spectrum of the 24 hour thermalized CQDs has a peak around $3400 \mathrm{~cm}^{-1}$ that has been assigned to $\mathrm{O}-\mathrm{H}$ stretching. The series of peaks around $2900 \mathrm{~cm}^{-1}$ have been assigned to C-H stretching. The sharp peak at $1530 \mathrm{~cm}^{-1}$ is characteristic of $\mathrm{C}=\mathrm{O}$, and that at $1450 \mathrm{~cm}^{-1}$ has been assigned to $\mathrm{C}=\mathrm{C}$ stretching (Appendix Figure 23). Our assignments and data are consistent with previous characterization of CQDs. ${ }^{120,233-235}$

Transmission electron microscopy (TEM) images of the 24 hour thermalized CQDs show formation of two distinct materials (Figure 6-3). Small aggregated structures approximately $100 \mathrm{~nm}$ in size composed of nanoparticles ranging from $10 \mathrm{~nm}$ to $20 \mathrm{~nm}$ are observed. These are similar to particles reported using the same preparation method. ${ }^{149}$ Large sheets composed of amorphous carbon are also observed. ${ }^{236}$ Previous reports on the synthesis of CQDs identify larger amorphous carbon domains alongside the CDQs. ${ }^{65}$ These images, together with NMR data, suggest a mixture of nano-materials rather than a homogenous CQD sample. TEM images of the PVP-coated CQD shows only amorphous carbon material, the polymer is not easily distinguishable from the CQDs (Figure 6-3C). 
After drop-casting solutions containing the CQDs, Ni NPs, and PVP, the aggregated components were imaged by TEM with EDX. TEM images taken of the Ni NPs mixed with PVP-coated CQDs show the $6 \mathrm{~nm}$ NiNPs within the PVP matrix, suggesting that they are likely closely associated in solution (Figure 6-2C). A coating of carbon material can be seen in these images, however, the carbon-containing polymer and CQDs cannot be distinguished using these techniques. EDX mapping shows overlaid nickel, oxygen, and carbon signals indicating relatively homogenous dispersion of the carbon (CQD and polymer) and nickel materials (Appendix Figure 24). Although dried imaging samples may not be completely indicative of solution behavior, these images, along with emission quenching studies described below lead us to believe the PVP, CQD and NiNPs are mixed together in solution. Imaging after catalysis was difficult due to the large amounts of PVP and EDTA present in the mixture. However, TEM images of a thin cross-section of the material display dark circular objects attributed to the NiNPs. These are no longer as uniform nor as well separated by the carbon material as the pre-reaction particles (Figure 6-2D). These images suggest aggregation of NiNPs as a possible explanation for the decreased catalytic activity. Larger NiNPs have previously been shown to be less catalytically active for $\mathrm{H}_{2}$ production. ${ }^{231}$ 

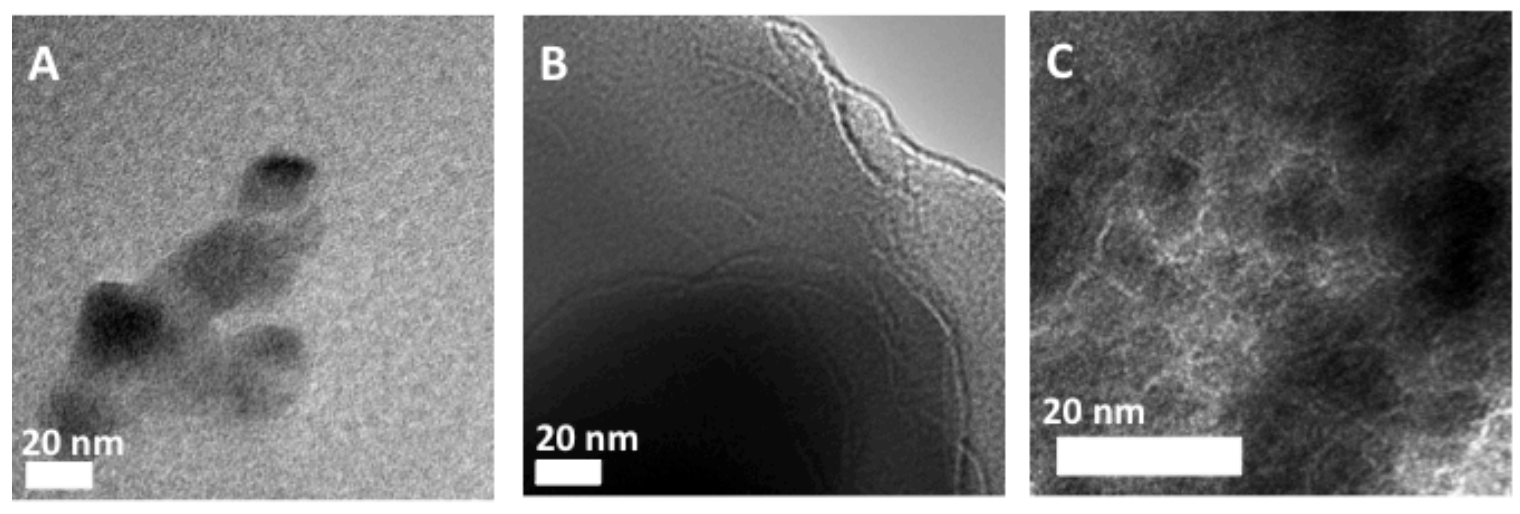

Figure 6-3: A) uncoated CQD sample showing approximately $20 \mathrm{~nm}$ structures aggregated together $\mathrm{B}$ ) uncoated CQD sample showing large amorphous sheets and C) PVP coated NiNPs and CQDs following irradiation with $470 \mathrm{~nm}$ light for 5 hours.

\subsubsection{Photoluminescence of PVP Coated CQDs}

PVP did not change the shape of the excitation or emission spectra of the CQDs; however fluorescence quantum yields were increased for PVP-coated samples relative to uncoated samples (Table 6-1). As expected, the photoluminescence spectra of the CQDs displayed excitation dependent emission (Figure 6-4). The CQDs have emission $\lambda_{\max }=456 \mathrm{~nm}$ when excited at $355 \mathrm{~nm}$. Excitation of the same sample at $470 \mathrm{~nm}$ (the wavelength used for $\mathrm{H}_{2}$ production experiments below) gives an emission at $\lambda_{\max }=$ $532 \mathrm{~nm}$ (Figure 6-4A). A shift in emission $\lambda_{\max }$ with varying excitation wavelength is documented for CQDs and has been attributed to quantum confinement effects in a highly polydisperse sample, and from diversity of emissive surface defects. ${ }^{228} \mathrm{UV}$-vis absorption of both uncoated and coated ( $0 \% \mathrm{wt}, 20 \mathrm{wt} \%$ and $50 \mathrm{wt} \%)$ particles display an onset of absorption starting around $700 \mathrm{~nm}$, with monotonically increasing absorption at shorter wavelengths, similar to previously published spectra (Figure 3B). ${ }^{116,228,230}$ 
Table 6-1: Quantum yields $(\Phi)$ for CQDs with various percentage PVP coatings by weight. Quantum yields were measured with $360 \mathrm{~nm}$ excitation and $470 \mathrm{~nm}$ excitation.

\begin{tabular}{|c|c|c|c|c|c|c|}
\hline & $0 \%$ & $5 \%$ & $10 \%$ & $20 \%$ & $35 \%$ & $50 \%$ \\
\hline $360 \mathrm{~nm}$ & $3.9 \%$ & $4.3 \%$ & $4.5 \%$ & $4.8 \%$ & $5.2 \%$ & $11.1 \%$ \\
\hline $470 \mathrm{~nm}$ & $0.4 \%$ & $0.8 \%$ & $1.1 \%$ & $1.4 \%$ & $1.3 \%$ & $1.4 \%$ \\
\hline
\end{tabular}

An increase in PVP causes an increase in fluorescence quantum yield, especially for excitation at $470 \mathrm{~nm}$ where over a three-fold increase in quantum yield (from $0.42 \%$ to $1.4 \%$ ) is observed when $20 \mathrm{wt} \%$ PVP is added (Table 6-1). The quantum yields were also found to be dependent on the excitation wavelengths (Appendix Table 3). Emission is observed with excitation energies as low as $525 \mathrm{~nm}$, however, as excitation becomes more red-shifted, quantum yields gradually decrease from $4.8 \%$ at $360 \mathrm{~nm}$ to $0.4 \%$ at $500 \mathrm{~nm}$ and become nearly negligible at $0.1 \%$ with $520 \mathrm{~nm}$ excitation. These suggest that non-radiative decay pathways are minimized due to the polymer coating.

Additional experiments were carried out to determine if PVP-coated CQDs were capable of undergoing upconversion as previously noted in the literature. ${ }^{113,114,237}$ Excitation with $720 \mathrm{~nm}$ light appears to give rise to a small emission peak at $\lambda_{\max }=456 \mathrm{~nm}$, the same that was observed when excited with $360 \mathrm{~nm}$ (Figure 6-4C). However, insertion of a shortpass filter $(<610 \mathrm{~nm})$ between the excitation source and sample, eliminating the scattered second order diffraction from the grating, results in complete elimination of the emission. This indicates that the emission observed without the shortpass filter is an artifact of the grating of the fluorometer, which allows second 
order diffraction of $\lambda / 2$ excitation light to hit the sample in addition to the desired excitation wavelength. Thus, CQDs' do not appear to upconvert NIR light under these conditions.
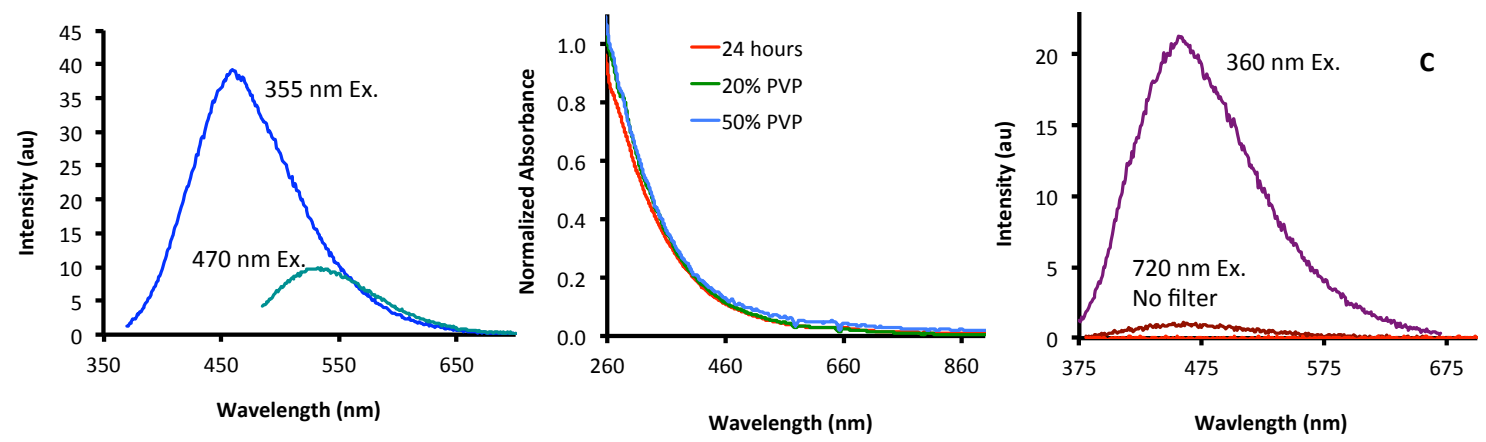

Figure 6-4: A) Emission for CQDs showing variation in emission based on excitation wavelength. B) UV-vis absorption spectra of CQDs with $0 \%, 20 \%$ and $50 \%$ PVP coating C) Emission of CQDs following excitation with 360 and $720 \mathrm{~nm}$; with and without a shortpass filter showing the disappearance of apparent upconversion with the filter in place.

\subsubsection{Hydrogen Production Using CQD Sensitizers and NiNP Catalysts.}

A maximum of $32( \pm 3.6) \mu$ mols of $\mathrm{H}_{2}$, corresponding $330 \mathrm{mmols} \mathrm{H}_{2} / \mathrm{g} \mathrm{CQD}$, was produced over 4 hours for a system containing $68 \mu \mathrm{g}$ of $20 \mathrm{wt} \%$ PVP-coated CQDs (Figure 6-5). $\mathrm{A} \mathrm{H}_{2}$ production quantum yield of $6 \%$ was determined using potassium ferrioxalate actinometry (see Supporting Information). ${ }^{146}$ The system by Reisner and coworkers with uncoated CQDs and Ni-P2N2 molecular catalyst produced $0.398 \mathrm{mmols}$ of $\mathrm{H}_{2} / \mathrm{g}$ CQD/h with a quantum efficiency of $1.4 \%$. ${ }^{65}$ Continuous $\mathrm{H}_{2}$ production was monitored using a Hiden Analytical Quadrupole Mass Analyzer sampling a flow of $\mathrm{N}_{2}$ 
gas through the irradiated reaction mixture. Solutions made with $0 \mathrm{wt} \%, 20 \mathrm{wt} \%$ and 50 wt\% PVP-coated CQDs under identical conditions show that increased polymer loading decreases the initial rate for $\mathrm{H}_{2}$ production (the initial rate was determined over a $10 \mathrm{~min}$ interval). The greatest amount of $\mathrm{H}_{2}$ was produced with for the $20 \mathrm{wt} \%$ PVP-coated CQDs over 5 hours, which is attributed to the intermediate amount of PVP stabilizing the system and allowing for an increase in the total amount of $\mathrm{H}_{2}$ produced (Figure 6-5A, Table 2). Though the initial rate of $\mathrm{H}_{2}$ production is lower for the $20 \% \mathrm{wt} \% \mathrm{PVP}$ coated CQD, due to the stabilizing effect of the PVP this rate is maintained, resulting in higher total amounts of $\mathrm{H}_{2}$ production. The $\mathrm{H}_{2}$ production rate remained the most consistent over an hour of irradiation with this intermediate amount of additional polymer.

After one hour, rates of $\mathrm{H}_{2}$ production decreased for all samples. Uncoated CQDs have the largest initial rate at $33 \mathrm{mmol} \mathrm{H} / \mathrm{g} \mathrm{CQD} / \mathrm{h}$ while PVP-coated CQDs at $20 \mathrm{wt} \%$ and $50 \mathrm{wt} \%$ produce $\mathrm{H}_{2}$ at rates of of 25 and $16 \mathrm{mmol}$ of $\mathrm{H}_{2} / \mathrm{g} \mathrm{CQD} / \mathrm{h}$ respectively (Table 6-2). For the uncoated CQDs the rate after 1 hour decreased to $19 \mathrm{mmol} \mathrm{H}_{2} / \mathrm{g}$ CQD/h while $\mathrm{H}_{2}$ production for the $20 \mathrm{wt} \%$ PVP-coated sample only decreased to $20 \mathrm{mmol} \mathrm{H}_{2} / \mathrm{g} \mathrm{CQD} / \mathrm{h}$. The rate of $\mathrm{H}_{2}$ production for the $50 \mathrm{wt} \%$ coated CQDs decreases to $7 \mathrm{mmol} \mathrm{H}_{2} / \mathrm{g} \mathrm{CQD} / \mathrm{h}$. We hypothesize that decreasing $\mathrm{H}_{2}$ production with increasing PVP beyond $20 \%$ by weight results from insulation that prohibits electron transfer thus decreasing overall $\mathrm{H}_{2}$ produced (Table 6-2). The insulating effect of the PVP in solution was observed by monitoring the effect of increased PVP on emission quenching. Emission of the CQDs was partially quenched by adding PVP-coated NiNPs. When an 
excess PVP was then added, the emission intensity increased, indicating excess PVP inhibits electron transfer from the CQD to the NiNP catalyst (Appendix Figure 25). This effect is observed without isolating the particles suggesting the PVP in solution is in dynamic contact with both the CQD and NiNP.
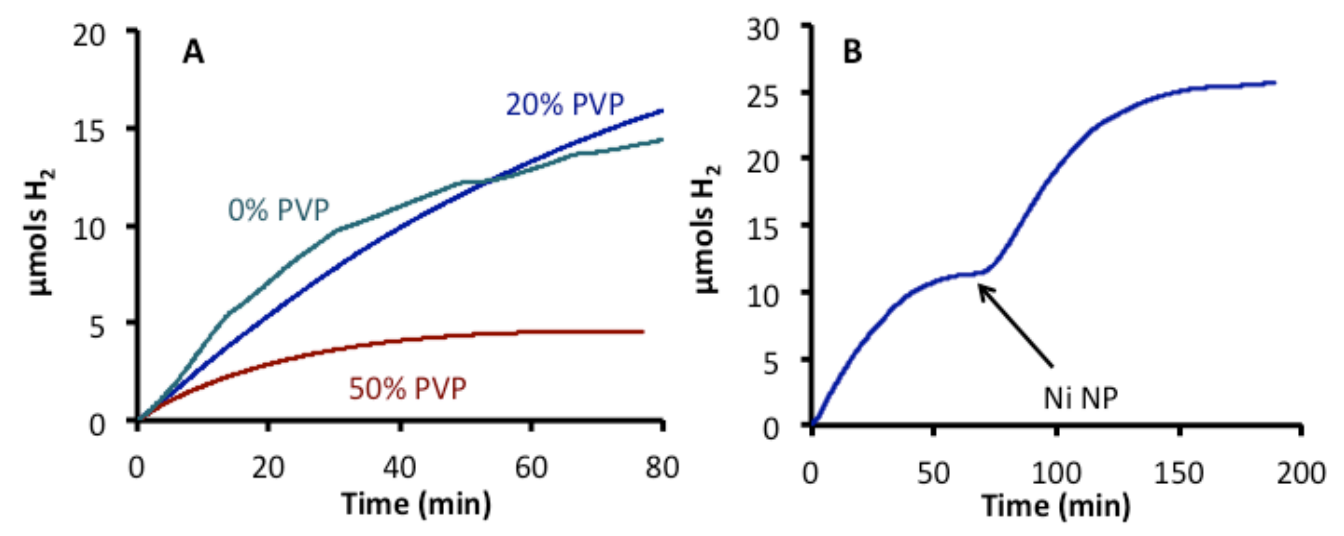

Figure 6-5: A) $\mathrm{H}_{2}$ production over time for uncoated, 20\% and 50\% PVP-coated CQDs. B) $\mathrm{H}_{2}$ production starting again following addition of $60 \mu \mathrm{g}$ NiNPs after initial decrease in $\mathrm{H}_{2}$ production at $70 \mathrm{~min}$. Reactions run using $60 \mu \mathrm{g}$ NiNPs and $680 \mu \mathrm{g}$ CQDs in 10 $\mathrm{mL}$ of $0.5 \mathrm{M}$ EDTA in $1: 1 \mathrm{H}_{2} \mathrm{O} / \mathrm{EtOH}$, irradiated with $470 \mathrm{~nm}$ LEDs.

Table 6-2: Instantaneous rates of $\mathrm{H}_{2}$ production of CQDs with varying polymer coating calculated at $\mathrm{t}=10 \mathrm{mins}$ and $\mathrm{t}=60 \mathrm{mins}$ using $6 \mu \mathrm{g} / \mathrm{mL}$ of NiNPs and $68 \mu \mathrm{g} / \mathrm{mL}$ of CQDs. Effect of PVP coating by weight percent of CQDs on total $\mathrm{H}_{2}$ production after $5 \mathrm{~h}$ in a total volume of $10 \mathrm{~mL}$.

\begin{tabular}{cccc}
\hline Instantaneous rate at & 0\% PVP & $\mathbf{2 0 \%}$ PVP & $\mathbf{5 0 \%}$ PVP \\
\hline 10 mins (mmols $\mathrm{H}_{2} / \mathrm{g}$ CQD/hour) & 33 & 25 & 16 \\
60 mins (mmols $\mathrm{H}_{2} / \mathrm{g}$ CQD/hour) & 19 & 20 & 7 \\
Total amount of $\mathrm{H}_{2}(\mu \mathrm{mol})$ & $20 \pm 2.8$ & $32 \pm 3.6$ & $6.4 \pm 1.1$ \\
\hline
\end{tabular}


Higher amounts of polymer coating on the CQDs likely increase the amount of polymer surrounding the NiNPs when mixed in solution. Supportive of this, TEM, SEM and EDX mapping of a mixture of CQD and NiNP with PVP coatings show that all components are uniformly aggregated together. PVP may inhibit catalyst aggregation, a mechanism of deactivation previously reported in the literature. ${ }^{238}$ Similar system instability has been reported for both NiNPs and PtNPs in photocatalytic $\mathrm{H}_{2}$ production. ${ }^{231}$
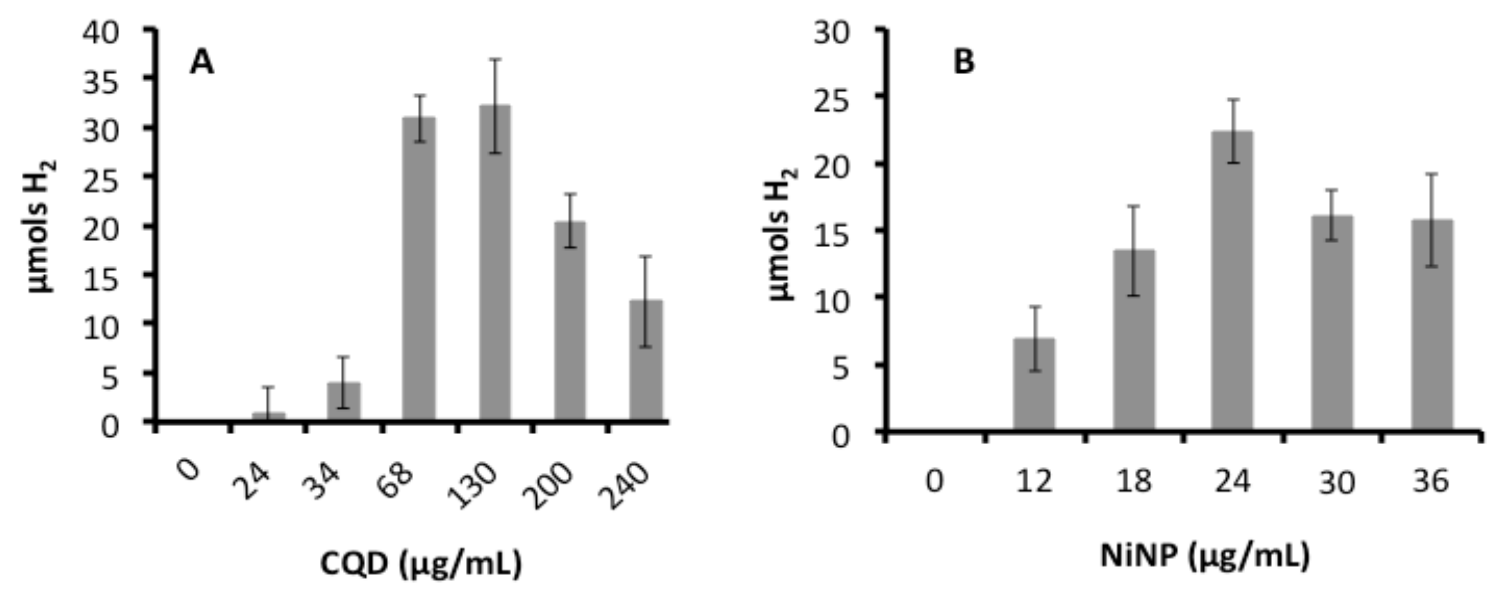

Figure 6-6: Effect of concentration of A) CQDs, with a constant $6 \mu \mathrm{g} / \mathrm{mL}$ of NiNPs and B) NiNPs, with a constant $68 \mu \mathrm{g} / \mathrm{mL}$ of CQD, on $\mathrm{H}_{2}$ production. $\mathrm{H}_{2}$ production amounts were measured over a period of five hours.

$\mathrm{H}_{2}$ production depends on the concentration of CQDs and NiNPs (Figure 6-6). Using a constant NiNP concentration $(6 \mu \mathrm{g} / \mathrm{mL})$, the CQD concentration was varied from $0-240 \mu \mathrm{g} / \mathrm{mL}$ (Figure 6-6A). Maximum $\mathrm{H}_{2}$ is produced using either $68 \mu \mathrm{g} / \mathrm{mL}$ or $130 \mu \mathrm{g} / \mathrm{mL} \mathrm{CQD}$ and production tapers off significantly with either more or less photosensitizer. Without CQDs, no $\mathrm{H}_{2}$ is detected. Higher concentrations of CQDs 
decrease $\mathrm{H}_{2}$ production, likely due to auto-quenching of the sensitizer. Using $68 \mu \mathrm{g} / \mathrm{mL}$ of $20 \mathrm{wt} \%$ PVP-coated CQDs as the sensitizer and varying NiNP concentrations, $\mathrm{H}_{2}$ production is maximized with $24 \mu \mathrm{g} / \mathrm{mL}$ of NiNP in solution. Over the course of 5 hours for a $10 \mathrm{~mL}$ volume, $22.4( \pm 2.4) \mu \mathrm{mols} \mathrm{H}_{2}$ is produced ( $330 \mathrm{mmols} \mathrm{H}_{2} / \mathrm{g}$ CQD). Any deviation from this concentration decreases $\mathrm{H}_{2}$ production, and without any NiNPs no $\mathrm{H}_{2}$ is detected. Variation in $\mathrm{H}_{2}$ production with increasing NiNP concentration may be due to competition by the catalysts for the reducing electrons.

Total amount of $\mathrm{H}_{2}$ is depends on the $\mathrm{pH}$ of solution. The optimal $\mathrm{pH}$ is the unadjusted value of 4.71 , formed by dissolving EDTA in a water/EtOH mixture. $\mathrm{H}_{2}$ production is lower at $\mathrm{pH} 3.13,7.06$ and 11.16 (Figure 6-7). This may be due to the sacrificial electron donor (SED) being less active in the protonated form at lower $\mathrm{pH}$, and proton reduction being less favored at higher $\mathrm{pH}$. A solution using $0.5 \mathrm{M}$ triethylamine (TEA) was also tested as a SED under basic conditions with a $\mathrm{pH}$ of 12.24 ; no $\mathrm{H}_{2}$ is produced in this case. Although TEA quenches sensitizer emission (Appendix Figure 26), we suspect the catalyst cannot be protonated due to the basicity of the solution, inhibiting $\mathrm{H}_{2}$ production. Additionally, using only water as the solvent results in no $\mathrm{H}_{2}$ production. 

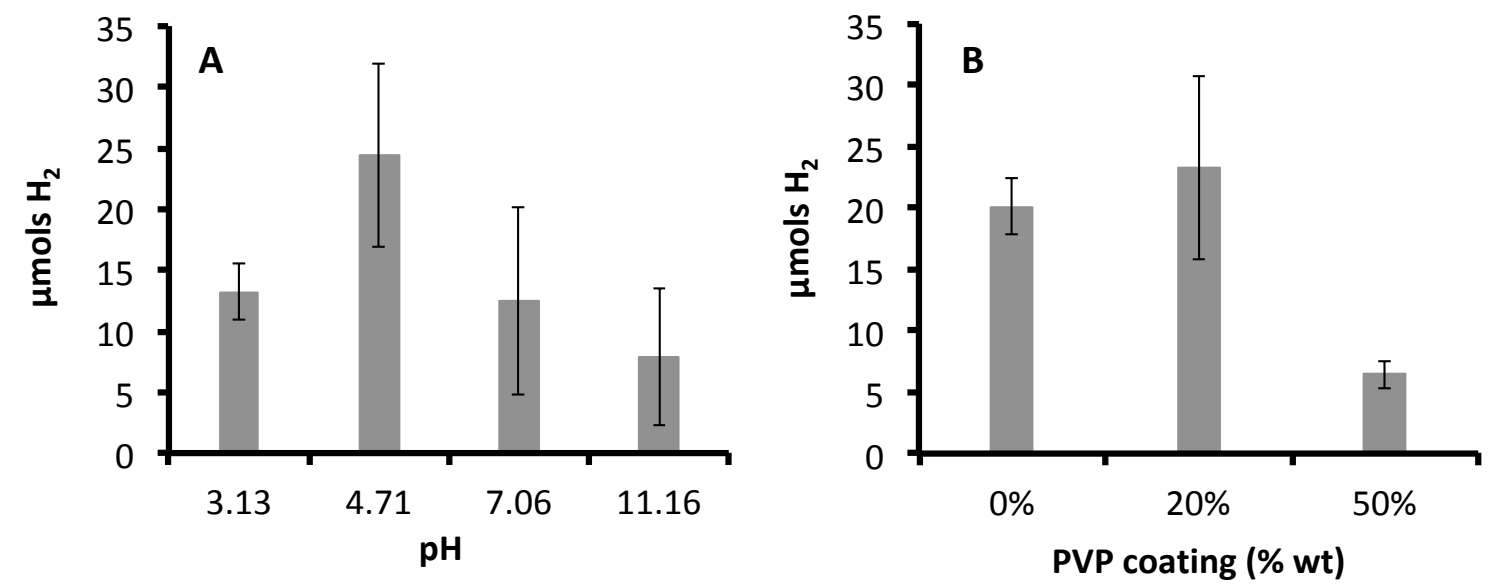

Figure 6-7: A) Effect of $\mathrm{pH}$ on total $\mathrm{H}_{2}$ production. Solution of $0.5 \mathrm{M}$ EDTA in 1:1 $\mathrm{H}_{2} \mathrm{O} / \mathrm{EtOH}$ used with $680 \mu \mathrm{g}$ CQD and $120 \mu \mathrm{g}$ NiNPs in a total volume of $10 \mathrm{~mL}$ B) Effect of PVP coating by weight percent of CQDs on total $\mathrm{H}_{2}$ production after $5 \mathrm{~h}$. Solution of $0.5 \mathrm{M}$ EDTA in $1: 1 \mathrm{H}_{2} \mathrm{O} / \mathrm{EtOH}$ used with $680 \mu \mathrm{g}$ CQD and $60 \mu \mathrm{g}$ NiNP in a total volume of $10 \mathrm{~mL}$.

Component stability was determined by re-introducing either the photosensitizer or catalyst after $\mathrm{H}_{2}$ production ceases. After $70 \mathrm{~min}$, a reaction containing $68 \mu \mathrm{g} / \mathrm{mL}$ $20 \mathrm{wt} \%$ PVP-coated CQDs and $6 \mu \mathrm{g} / \mathrm{mL}$ NiNPs stops producing $\mathrm{H}_{2}$. Upon addition of a $180 \mu \mathrm{g}$ aliquot of NiNPs into $10 \mathrm{~mL}$ of solution, $\mathrm{H}_{2}$ production resumes (Figure 6-8B). Subsequent aliquot addition every 30 min maintains $\mathrm{H}_{2}$ production for $150 \mathrm{~min}$, although the rate of hydrogen production decreases with each aliquot (Figure 6-8). An analogous experiment was performed where $2 \mathrm{mg}$ of CQDs were added after $130 \mathrm{~min}$. The rate of $\mathrm{H}_{2}$ production does not significantly increase with addition of CQD (Figure 6-8). These results suggest that the CQD sensitizer could be recycled however the NiNP catalyst could not. Using $180 \mu \mathrm{g}$ of NiNPs and $2000 \mu \mathrm{g}$ of CQDs in $30 \mathrm{~mL}$ of $0.5 \mathrm{M}$ EDTA in 1:1 EtOH/water, $\mathrm{H}_{2}$ production continued without additions for nearly four hours. These 
observations support that deactivation of the NiNP catalyst primarily causes cessation of $\mathrm{H}_{2}$ production.
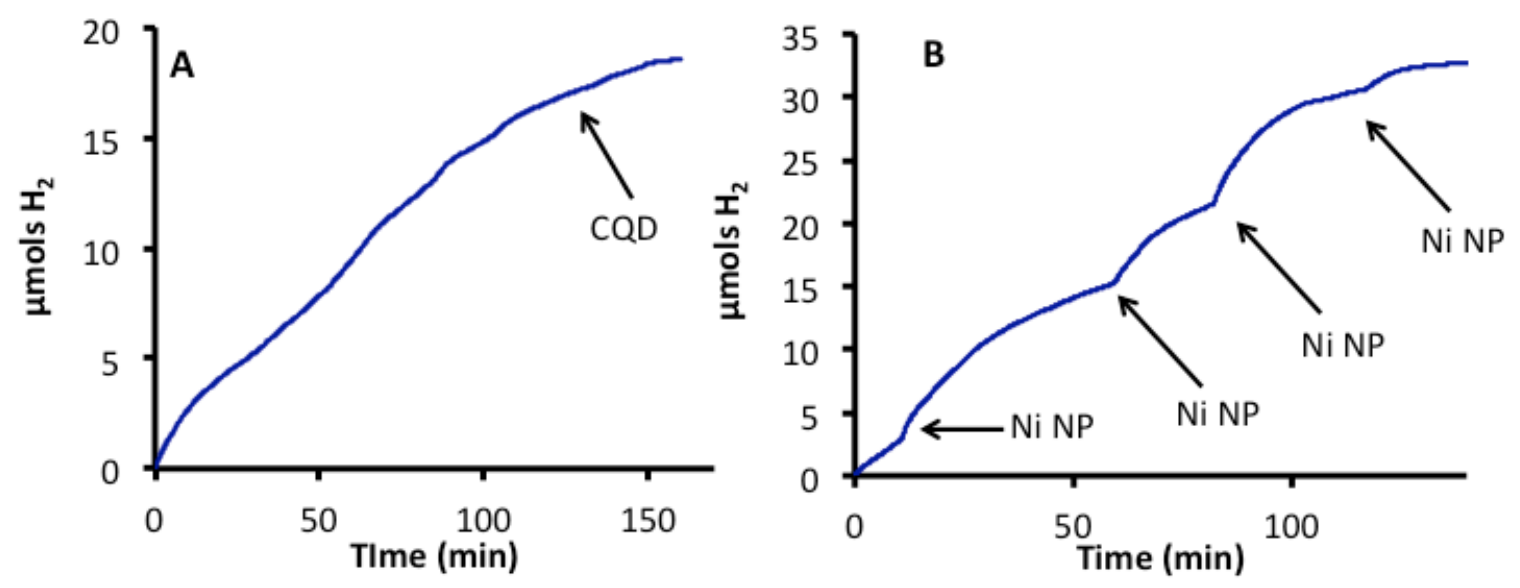

Figure 6-8: A) $\mathrm{H}_{2}$ production over time with CQD added after 130 minutes B) $\mathrm{H}_{2}$ production over time with continued addition of NiNPs as indicated by arrows to maintain production for 150 minutes. Solution of $0.5 \mathrm{M}$ EDTA in 1:1 $\mathrm{H}_{2} \mathrm{O} / \mathrm{EtOH}$ used with $680 \mu \mathrm{g}$ CQD / $10 \mathrm{~mL}$ and $60 \mu \mathrm{g}$ NiNP / $10 \mathrm{~mL}$ in total volume of $30 \mathrm{~mL}$.

\subsubsection{Mechanistic Investigation via Fluorescence Quenching Titrations.}

To gain insight into the mechanism of CQD sensitized $\mathrm{H}_{2}$ production, including how the sensitizer and catalyst interact with each other in solution, fluorescencequenching titrations were performed with a $10 \mathrm{~mL}$ CQD solution $(68 \mu \mathrm{g} / \mathrm{mL})$ in $1: 1$ EtOH/water. EDTA or NiNPs were added to the CQD solutions to observe reductive or oxidative quenching respectively. Quenching was observed in both cases. This indicates that electron transfer is possible both from the electron donor to the photosensitizer, and from the photosensitizer directly to the catalyst. The quenching rate coefficients for the EDTA SED is calculated from plots of $\mathrm{I}_{0} / \mathrm{I}$ vs concentration of quencher to be 1679.9 
mol $^{-1}$ (Appendix Figure 26). This indicates that $\mathrm{H}_{2}$ production with EDTA as the SED could occur via a reductive quenching pathway. TEA caused emission quenching but did not act as a sacrificial electron donor for hydrogen production. Two other sacrificial electron donors, triethanol amine and ascorbic acid, caused minimal $\left(3.7 \mathrm{~mol}^{-1}\right)$ or no quenching respectively. The solution of NiNPs in EtOH causes emission quenching (Appendix Figure 27). With continuous addition of NiNPs up to $1 \mathrm{mg} / \mathrm{mL}$, the fluorescence gradually quenches, indicating that the oxidative quenching pathway could also contribute to the $\mathrm{H}_{2}$ production mechanism. To further test the hypothesis that observed quenching was a result of electron transfer, and not energy transfer, experiments using methyl viologen (MV) as an oxidant and as an electron transfer indicator dye, were performed. Emission of the CQDs is quenched using MV (Appendix Figure 28). Additionally, an air-free solution containing CQDs, MV and EDTA was irradiated with $360 \mathrm{~nm}$ light and the solution subsequently turned blue indicating electron transfer to the MV from the photosensitizer. A solution without CQDs did not produce a significant color change.

\subsection{Conclusions}

In summary we have demonstrated that $\mathrm{H}_{2}$ is produced photocatalytically using PVP-coated CQDs and NiNPs when irradiated with $470 \mathrm{~nm}$ light. A system containing $68 \mu \mathrm{g} / \mathrm{mL}$ of CQD and $6 \mu \mathrm{g} / \mathrm{mL}$ of NiNPs (10 mL solution) produced is $32( \pm 3.6) \mu \mathrm{mols}$ of $\mathrm{H}_{2}$ ( $330 \mathrm{mmols} \mathrm{H}_{2} / \mathrm{g} \mathrm{CQD}$ ). Activity without re-addition continued for nearly four hours, though most $\mathrm{H}_{2}$ was produced in the first two hours as the reaction rate decreased. 
Properties of the CQDs were studied to correlate how the photophysical properties relate to $\mathrm{H}_{2}$ production. Addition of PVP to the CQDs caused an increase in fluorescence quantum yield. The increased emission quantum yield correlated to an increased amount of $\mathrm{H}_{2}$ production for the $20 \%$ coated particles. Interestingly, we note that though quantum yield increases as the amount of PVP by weight is increased, after $20 \% \mathrm{H}_{2}$ production is significantly suppressed due to an insulating effect of the polymer prohibiting electron transfer. 


\section{CHAPTER 7}

\section{CONCLUSIONS}

\section{A multifaceted approach to understanding solar energy conversion systems}

The production of hydrogen as a fuel source provides several avenues to develop fundamental scientific understanding while simultaneously contributing to the improvement of renewable energy technology. Photochemical and electrochemical methods are studied in unique ways and each divulges information that can be used to guide the development of catalytic materials and systems. Both computational and experimental methods can be used to understand the complex catalytic cycles of hydrogen production by molecular catalysts, while the study of nanomaterials using this joint approach remains markedly more complex. As such purely experimental methods were used to probe photochemical hydrogen production using a composite nanomaterial system.

On the other hand, our initial investigation of catalytic hydrogen production by $\mathrm{Ni}(\mathrm{PyS})_{3}{ }^{-}$demonstrates the usefulness of using computational and experimental methods to study intermediates and transition states throughout the catalytic cycle of proton reduction. Specifically, the DFT calculations performed herein supported the experimentally proposed catalytic cycle while providing insight into intermediate geometries and the location of electrons for reduced intermediates. Our investigation revealed that protonation at a pyridyl nitrogen is necessary prior to reduction, so as to lower the required overpotential. The experimentally tested system studied by Eiseberg 
and coworkers utilized $\mathrm{Ni}(\mathrm{PyS})_{3}{ }^{-}$as a photocatalyst in conjunction with a fluorescein sensitizer, and without initial protonation, electron transfer from the sensitizer could not occur. Protonation leads to ligand dechelation, which opens a coordination site at the nickel center. The possibility of water coordination was explored but found to be disfavored, and though coordination of hydroxide was energetically possible, it was determined to likely form an inert intermediate.

Exploration of the spin density of $\mathrm{Ni}(\mathrm{PyS}){ }_{3} \mathrm{H}^{\mathrm{N}-}$ revealed that electron density at this step is localized around the metal center. Another feature of this part of the catalytic cycle that could have been difficult to probe experimentally is the formation of the nickel-hydride intermediate $\mathrm{Ni}(\mathrm{PyS})_{3} \mathrm{H}^{\mathrm{N}} \mathrm{H}^{\mathrm{Ni}-}$. Computations provided support for the formation of this intermediate by analyzing the thermodynamics of a sequential protonelectron transfer, as well as by studying the spin density maps of this intermediate in differing spin states. Hydrogen elimination from the nickel hydride was then found to be a facile step. Through a computational exploration using DFT, we were able to provide support for a previously proposed mechanism. The use of joint theoretical and experimental methods provided details about the catalytic cycle, which prompted us to consider modifications to the catalyst that could then be studied using the same methodology.

The results of the initial investigation of $\mathrm{Ni}(\mathrm{PyS})_{3}{ }^{-}$demonstrated that a systematic approach could be used to undertake the study of hydrogen production by molecular proton reduction catalysts using computational and experimental results. To further 
understand how molecular nickel catalysts produce hydrogen, this method was applied in the exploration of the effect of slight electronic modifications to the ligands of $\mathrm{Ni}(\mathrm{PyS})_{3}{ }^{-}$ type compounds. The effectiveness of these compounds was determined by studying their rates of hydrogen production when used as electrocatalysts and by measuring their physical properties. Specifically, the $\mathrm{p} K_{a}$ and $\mathrm{E}^{0}$ values of each compound were measured experimentally, and generated computationally as well. The mechanism of hydrogen production undertaken by each derivative was probed using the same method which previously allowed us to support a CECE mechanism of hydrogen production for $\mathrm{Ni}(\mathrm{PyS})_{3}$.

A total of six derivatives of $\mathrm{Ni}(\mathrm{PyS})_{3}{ }^{-}$were synthesized and characterized. In this way, the effects of ligand modification could be evaluated on the basis of how they modulated compound properties and how that resulted in changed in the hydrogen production mechanisms of said compounds. What we found was that compounds containing electron poor ligands had a tendency to maintain the CECE mechanism followed by $\mathrm{Ni}(\mathrm{PyS})_{3}{ }^{-}$. The initial reduction step was found to be metal centered, as it was for $\mathrm{Ni}(\mathrm{PyS})_{3}{ }_{3}$, and for each derivative the overpotential of this step is greater than that required than for the second reduction step. TOF's of these derivatives are likely limited by this overpotential. Computed and experimental values of $\mathrm{E}^{0}$ and $\mathrm{p} K_{a}$ for the first two steps of the CECE catalytic cycles show a linear correlation with corresponding Hammett-constants. The relationship between the two parameters was found to be inversely favorable, with higher $\mathrm{p} K_{a}$ values and higher $\mathrm{E}^{0}$ values occurring under the 
same conditions, and low $\mathrm{p} K_{a}$ values and low $\mathrm{E}^{0}$ values occurring under the same conditions. The CECE mechanism of $\mathrm{Ni}(\mathrm{PyS})_{3}{ }^{-}$was the most profoundly affected by substitution with an electron rich ligand. It was found to cause a shift to a favored CCEE mechanism, which involves a proton shift from a pyridyl nitrogen to the nickel center following the second protonation. This was determined to likely be the result of a drastic change in physical properties as a result of increased electron rich character of the ligands. By looking at the effects of electron density on physical properties and catalytic mechanisms, we were able to identify the important characteristics of a proton reduction catalyst that promote favorable properties and, ultimately, should improve rates of hydrogen production.

Electron rich ligands were shown to increase the proton affinity of $\mathrm{Ni}(\mathrm{PyS})_{3}{ }^{-}$type catalysts, while electron poor ligands were shown to reduce the required overpotential for the first reduction step when a CECE mechanism is undertaken. Our next goal was to use this information to design catalyst that combined these two elements, in order to create a compound with both high proton affinity and low overpotentials for hydrogen production. Heteroleptic compound were thus designed using different ratios of substituted to unsubstituted ligands to see if we could exert control over the $\mathrm{p} K_{a}$ and $\mathrm{E}^{0}$ values of the compounds. Our expectation was that electron rich ligands would provide favored sites of protonation and electron poor ligands would reduce the required potential to drive hydrogen production. 
Although we found that we can make fairly accurate predictions about general trends for the physical properties of heteroleptic catalysts, the specific mechanism and efficiency of hydrogen production are much more difficult to predict on the basis of nonuniform addition of electron donating and withdrawing substituents. Experimentally determined properties of all four heteroleptic catalyst were found to follow the general trends we expected, but the physical properties alone could not provide enough information about the intricacies of the catalytic process, which ultimately give us the ability to improve catalyst structure. Part of the challenge in predicting reactivity arises from the complexity that is introduced by creating a large number of possible isomers for each heteroleptic compound. Because each isomer has corresponding unique physical properties, the concentration of active catalyst in solution fluctuates throughout the course of the reaction, leading to inconsistencies in measured rates of hydrogen production.

Computed and experimental data for the four heteroleptic compounds studied revealed that the placement of unique ligands greatly impacted the physical properties of each isomer, particularly the $\mathrm{p} K_{a}$ values. This effect was even greater than electronic effects in some situations. This result impacts how future catalysts are designed by providing evidence that ligand placement, in addition to the electronics of the ligands themselves, is just as important in dictating the resulting properties of the compound. Putting an electron rich ligand in the central position drastically decreased the proton affinity, thereby negating any benefits of placing an electron rich ligand in that position. 
The thermodynamics of the formation of each isomer of the starting catalysts was investigated and it was noted that the most stable isomer in some cases is not the most catalytically active. In some cases, the most stable isomer is catalytically inert under neutral reaction conditions. Due to isomerization through the course of the catalytic cycle, the concentration of active catalyst was hypothesized to decrease as hydrogen production occurs for certain compound. Thus, creating structural features that promote the initial formation and subsequent maintenance of a particularly active isomer could be a strategy for how to improve catalysts for many areas of chemistry. Geometry could be maintained through the use of a 4-coordinate ligand, which would also impart a measure of control over the mechanism through which catalysis proceeds.

This strategy could extend beyond the area of renewable energy and into areas such as targeted catalysis for synthesis of enantioselective products, for example. Additionally, understanding the underlying structural features of heteroleptic compounds that results in a diversity of physical properties is an important next step in the further development of effective catalysts that can selectively be tuned to operate through a particular mechanism. Current computational investigation continues to explore the origin of variability in physical properties as well as to target strategies that may be used in the selective synthesis of desired isomers. This work leads us to hypothesize that favoring the most active heteroleptic catalysts would lead to greatly enhanced catalytic effectiveness, as well as improved understanding of the operative mechanism by which they proceed. 
In addition to improving the effectiveness of hydrogen production by electrocatalysts, structural modification to alter the physical properties of catalysts is a useful strategy when working with photocatalysis as well. One of the great challenges of working with photocatalytic systems is ensuring the appropriate alignment of energy levels for each component. If the excited state of the selected photosensitizer is unable to transfer an electron to the catalyst, then no product can be formed. Modifying either the sensitizer or catalyst in order to properly align these energy levels may have detrimental consequences on other important parameters, such as $\mathrm{p} K_{a}$, as we demonstrated in the previous computational and experimental work. One way to broadly circumnavigate the issue of misaligned energy levels is through the use of nanomaterials, such as in our work using CQDs and NiNPs to produce hydrogen photocatalytically. Because of the wide range of excitation and emission energies of CQDs, they can effectively sensitize different species. In our particular work, hydrogen gas was produced photocatalytically using $470 \mathrm{~nm}$ light, PVP-coated CQDs and NiNPs. The study examined how the concentration of PVP affected the ability of CQD/NiNP composites to catalyze proton reduction. Composites made with a higher weight percent PVP showed decreased rates of hydrogen production, however this production was maintained over a longer period of time. Interestingly, an increase in the weight percent of PVP coating lead to an increase in the fluorescence quantum yield of the CQDs.

Ultimately, though the nanomaterials effectively produced hydrogen with visible light and were synthesized using simple procedures and inexpensive materials, their 
fundamental drawback comes from the difficulty with which they can be studied. As we have seen, molecular proton reduction catalysts can be probed in depth using computational and experimental methods. In order to study the mechanism of hydrogen production by $\mathrm{CQD} / \mathrm{NiNP}$ composites, certain luminescence quenching methods were utilized, with a specific emphasis on using fluorescence quenching titrations. However, these studies revealed only that hydrogen production could be occurring through either a reductive or oxidative quenching mechanism. Add-in experiments indicate that decomposition of the catalyst and the sensitizer both contributed to a decrease in hydrogen production, but no further details beyond this were identified. Clearly, though a functional, tunable hydrogen production system can be made using easily synthesized nanomaterials, mechanistic characterization using a joint theoretical and computational approach remains a more feasible process for studying molecular hydrogen production catalysts. 


\section{REFERENCES}

(1) Friedlingstein, P.; Andrew, R. M.; Rogelj, J.; Peters, G. P.; Canadell, J. G.; Knutti, R.; Luderer, G.; Raupach, M. R.; Schaeffer, M.; Vuuren, D. P. Van; Quéré, C. Le. Persistent Growth of $\mathrm{CO} 2$ Emissions and Implications for Reaching Climate Targets. Nat. Publ. Gr. 2014, 7, 709-715.

(2) Orbach, R. L. Our Sustainable Earth. Reports Prog. Phys. 2011, 74, 112801.

(3) Lewis, N. S. Powering the Planet. MRS Bull. 2007, 32, 808-820.

(4) Li, K.; An, X.; Park, K. H.; Khraisheh, M.; Tang, J. A Critical Review of CO2 Photoconversion: Catalysts and Reactors. Catal. Today 2014, 224, 3-12.

(5) McGuire, A. D.; Sitch, S.; Clein, J. S.; Dargaville, R. Carbon Balance of the Terrestrial Biosphere in the Twentieth Century. Global Biogeochemical Cycles, 2001, 5, 183-206.

(6) Justin, D.; Rabalais, N. N.; Turner, R. E. Effects of Climate Change on Hypoxia in Coastal Waters: A Doubled CO2 Scenario for the Northern Gulf of Mexico. Limnol. Oceanogr. 1996, 41, 992-1003.

(7) Malcolm, J. R.; Liu, C.; Neilson, R. P.; Hansen, L.; Hannah, L. Global Warming and Extinctions of Endemic Species from Biodiversity Hotspots. Conserv. Biol. 2006, 20, 538-548.

(8) Doney, S. C.; Fabry, V. J.; Feely, R. a; Kleypas, J. a. Ocean Acidification: The Other CO2 Problem. Ann. Rev. Mar. Sci. 2009, 1, 169-192.

(9) Manabe, S.; Stouffer, R. J. Century-Scale Effects of Increased Atmoshperic CO2 
on the Ocean-Atmosphere System. Nature, 1993, 364, 215-218.

(10) Fang, X.; Stefan, H. G. Simulations of Climate Effects on Water Temperature, Dissolved Oxygen, and Ice and Snow Covers in Lakes of the Contiguous U.S. under Past and Future Climate Scenarios. Limnol. Oceanogr. 2009, 54, 23592370.

(11) Ezeh, a C.; Bongaarts, J.; Mberu, B. Global Population Trends and Policy Options. Lancet 2012, 380, 142-148.

(12) Gerland, P.; Raftery, a. E.; Ev Ikova, H.; Li, N.; Gu, D.; Spoorenberg, T.; Alkema, L.; Fosdick, B. K.; Chunn, J.; Lalic, N.; Bay, G.; Buettner, T.; Heilig, G. K.; Wilmoth, J. World Population Stabilization Unlikely This Century. Science (80-. ). 2014, 346, 234-237.

(13) Martinot, E.; Chaurey, A.; Lew, D.; Moreira, J. R.; Wamukonya, N. Renewable Energy Markets in Developing Countries*. Annu. Rev. Energy Environ. 2002, 27, 309-348.

(14) Jorgenson, A. K. Economic Development and the Carbon Intensity of Human Well-Being. Nat. Clim. Chang. 2014, 4, 10-13.

(15) Ponce De Leon Barido, D.; Marshall, J. D. Relationship between Urbanization and CO2 Emissions Depends on Income Level and Policy. Environ. Sci. Technol. 2014, 48, 3632-3639.

(16) Nelson, V. Key World Energy Statistics 2013. Int. Energy Agency 2013, 17-44.

(17) Hertwich, E. G.; Gibon, T.; Bouman, E.; Arvesen, A.; Suh, S.; Heath, G.; 
Bergesen, J. D.; Ramirez, A.; Vega, M. I.; Shi, L. Integrated Life-Cycle Assessment of Electricity-Supply Scenarios Confirms Global Environmental Benefit of Low-Carbon Technologies. Proc. Natl. Acad. Sci. 2014.

(18) Balzani, V.; Credi, A.; Venturi, M. Photochemical Conversion of Solar Energy; 2008; Vol. 1.

(19) Moulé, A. J. Power from Plastic. Curr. Opin. Solid State Mater. Sci. 2010, 14, $123-130$.

(20) Xiao, S.; Xu, S. High-Efficiency Silicon Solar Cells-Materials and Devices Physics. Crit. Rev. Solid State Mater. Sci. 2014, 39, 277-317.

(21) Mark Bolinger, Joachim Seel, K. H. L. Utility-Scale Solar 2015: An Empirical Analysis of Project Cost, Performance, and Pricing Trends in the United States. 2017, 6-12.

(22) Barkhouse, D. A. R.; Gunawan, O.; Gokmen, T.; Todorov, T. K.; Mitzi, D. B. Solar Cell Efficiency Tables (Version 45). Prog. Photovoltaics Res. Appl. 2012, $20,6-11$.

(23) Green, M. A. Crystalline and Thin-Film Silicon Solar Cells : State of the Art and Future Potential. Elsevier 2003, 74, 181-192.

(24) Hsu, C.-H.; Wu, J.-R.; Lu, Y.-T.; Flood, D. J.; Barron, A. R.; Chen, L.-C. Fabrication and Characteristics of Black Silicon for Solar Cell Applications: An Overview. Mater. Sci. Semicond. Process. 2014, 25, 2-17.

(25) Yoshikawa, K.; Kawasaki, H.; Yoshida, W.; Irie, T.; Konishi, K.; Nakano, K.; Uto, 
T.; Adachi, D.; Kanematsu, M.; Uzu, H.; Yamamoto, K. Silicon Heterojunction Solar Cell with Interdigitated Back Contacts for a Photoconversion Efficiency over 26\%. Nat. Energy 2017, 2.

(26) Chen, Y.-H. H.; Paltsev, S.; Reilly, J.; Morris, J.; Karplus, V.; Gurgel, A.; N. Winchester, P. K.; Blanc, É.; Babiker, M. The MIT Economic Projection and Policy Analysis (EPPA) Model: Version 5. 2017, Technical.

(27) Sargent, H.; Sargent, E. H. Colloidal Quantum Dot Solar Cells. Nat. Photonics 2012, 6, 133-135.

(28) Fu, R.; Chung, D.; Lowder, T.; Feldman, D.; Ardani, K.; Fu, R.; Chung, D.; Lowder, T.; Feldman, D.; Ardani, K. U . S . Solar Photovoltaic System Cost Benchmark: Q1 2016 U . S . Solar Photovoltaic System Cost Benchmark: Q1 2016. Nrel 2016.

(29) Cao, W.; Xue, J. Recent Progress in Organic Photovoltaics: Device Architecture and Optical Design. Energy Environ. Sci. 2014, 2123-2144.

(30) Gu, S.; Neugebauer, H.; Sariciftci, N. S. Conjugated Polymer-Based Organic Solar Cells. Chem.Rev. 2007, 1324-1338.

(31) Roncali, J.; Leriche, P.; Blanchard, P. Molecular Materials for Organic Photovoltaics: Small Is Beautiful. Adv. Mater. 2014, 26, 3821-3838.

(32) Schön, J. H.; Kloc, C.; Dodabalapur, A.; Batlogg, B. Organic Single Crystals for Electronic and Optoelectronic Devices. MRS Proc. 2000, 10, 1-25.

(33) Jackson, N. E.; Savoie, B. M.; Marks, T. J.; Chen, L. X.; Ratner, M. a. The Next 
Breakthrough for Organic Photovoltaics? J. Phys. Chem. Lett. 2015, 6, 77-84.

(34) Kim, J. Y.; Lee, K.; Coates, N. E.; Moses, D.; Nguyen, T.; Dante, M.; Heeger, A. J. Efficient Tandem Polymer Solar Cells Fabricated by All-Solution Processing. Science (80-. ). 2007, 317, 222-226.

(35) Thompson, B. C.; Fréchet, J. M. J. Polymer-Fullerene Composite Solar Cells. Angew. Chemie - Int. Ed. 2008, 47, 58-77.

(36) Li, G.; Shrotriya, V.; Huang, J.; Yao, Y.; Moriarty, T.; Emery, K.; Yang, Y. HighEfficiency Solution Processable Polymer Photovoltaic Cells by Self-Organization of Polymer Blends. Nat. Mater. 2005, 4, 864-868.

(37) Mazzio, K. a.; Luscombe, C. K. The Future of Organic Photovoltaics. Chem. Soc. Rev. 2015, 44, 78-90.

(38) Ponomarenko, S. a; Luponosov, Y. N.; Min, J.; Solodukhin, a N. Design of Donor - Acceptor Star-Shaped Oligomers for E Ffi Cient Solution- Processible Organic Photovoltaics †. Faraday Discuss. 2014, 174, 1-27.

Li, M.; Gao, K.; Wan, X.; Zhang, Q.; Kan, B.; Xia, R.; Liu, F.; Yang, X.; Feng, H.; Ni, W.; Wang, Y.; Peng, J.; Zhang, H.; Liang, Z.; Yip, H. L.; Peng, X.; Cao, Y.; Chen, Y. Solution-Processed Organic Tandem Solar Cells with Power Conversion Efficiencies $>12 \%$. Nat. Photonics 2017, 11, 85-90.

(40) Baran, D.; Ashraf, R. S.; Hanifi, D. A.; Abdelsamie, M.; Gasparini, N.; Röhr, J. A.; Holliday, S.; Wadsworth, A.; Lockett, S.; Neophytou, M.; Emmott, C. J. M.; Nelson, J.; Brabec, C. J.; Amassian, A.; Salleo, A.; Kirchartz, T.; Durrant, J. R.; 
McCulloch, I. Reducing the Efficiency-Stability-Cost Gap of Organic Photovoltaics with Highly Efficient and Stable Small Molecule Acceptor Ternary Solar Cells. Nat. Mater. 2017, 16, 363-369.

(41) Zhao, W.; Li, S.; Yao, H.; Zhang, S.; Zhang, Y.; Yang, B.; Hou, J. Molecular Optimization Enables over 13\% Efficiency in Organic Solar Cells. J. Am. Chem. Soc. 2017, 139, 7148-7151.

(42) Sum, T. C.; Mathews, N. Advancements in Perovskite Solar Cells: Photophysics behind the Photovoltaics. Energy Environ. Sci. 2014, 2518-2534.

(43) Green, M.; Ho-Baillie, A.; Snaith, H. J. The Emergence of Perovskite Solar Cells. Nat. Photonics 2014, 8, 506-514.

(44) Zhou, H.; Chen, Q.; Li, G.; Luo, S.; Song, T.-B.; Duan, H.-S.; Hong, Z.; Liu, Y.; Yang, Y. Interface Engineering of Highly Efficient Perovskite Solar Cells. Science (80-. ). 2013, 27, 238-242.

(45) Christians, J. A.; Schulz, P.; Tinkham, J. S.; Schloemer, T. H.; Harvey, S. P.; Villers, B. J. T. de; Sellinger, A.; Berry, J. J.; Luther, J. M. Tailored Interfaces of Unencapsulated Perovskite Solar Cells for $>1,000$ Hour Operational Stability. Nat. Energy 2018, 3, DOI: 10.1038/s41560-017-0067-y.

(46) Niu, G.; Li, W.; Meng, F.; Wang, L.; Dong, H.; Qiu, Y. Study on the Stability of $\mathrm{CH}_{3} \mathrm{NH}_{3} \mathrm{PbI}_{3}$ Films and the Effect of Post-Modification by Aluminum Oxide in All-Solid-State Hybrid Solar Cells. J. Mater. Chem. A 2014, 2, 705-710.

(47) Dunn, B.; Kamath, H.; Tarascon, J.-M. Electrical Energy Storage for the Grid: A 
Battery of Choices. Science (80-. ). 2011, 334, 928-935.

(48) Ibrahim, H.; Ilinca, a.; Perron, J. Energy Storage Systems-Characteristics and Comparisons. Renew. Sustain. Energy Rev. 2008, 12, 1221-1250.

(49) Hou, Y.; Vidu, R.; Stroeve, P. Solar Energy Storage Methods. Ind. Eng. Chem. Res. 2011, 50, 8954-8964.

(50) Lund, H.; Salgi, G. The Role of Compressed Air Energy Storage (CAES) in Future Sustainable Energy Systems. Energy Convers. Manag. 2009, 50, 1172-1179.

(51) Schoenung, S. M.; Hassenzahl, W. Characteristics and Technologies for Long-vs. Short-Term Energy Storage A Study by the DOE Energy Storage Systems Program SAND2001-0765. Sandia Natl. Lab. U.S. Dept. Energy 2001, 1-46.

(52) Divya, K. C.; Østergaard, J. Battery Energy Storage Technology for Power systems-An Overview. Electr. Power Syst. Res. 2009, 79, 511-520.

(53) Tachibana, Y.; Vayssieres, L.; Durrant, J. R. Artificial Photosynthesis for Solar Water-Splitting. Nat. Photonics 2012, 6, 511-518.

(54) Barber, J. Photosynthetic Energy Conversion: Natural and Artificial. Chem. Soc. Rev. 2009, 38, 185-196.

(55) Fujishima, A.; Honda, K. Electrochemical Photolysis of Water at a Semiconductor Electrode. Nature 1972, 238, 37-38.

(56) Kim, D.; Sakimoto, K. K.; Hong, D.; Yang, P. Artificial Photosynthesis for Sustainable Fuel and Chemical Production. Angew. Chemie Int. Ed. 2015, 32593266. 
(57) Osterloh, F. E. Inorganic Nanostructures for Photoelectrochemical and Photocatalytic Water Splitting. Chem. Soc. Rev. 2013, 2294-2320.

(58) Liao, C.-H.; Huang, C.-W.; Wu, J. C. S. Hydrogen Production from Semiconductor-Based Photocatalysis via Water Splitting. Catalysts 2012, 2, 490516.

(59) Wang, M.; Chen, L.; Sun, L. Recent Progress in Electrochemical Hydrogen Production with Earth-Abundant Metal Complexes as Catalysts. Energy Environ. Sci. 2012, 5, 6763 .

(60) Doyle, R. L.; Godwin, I. J.; Brandon, M. P.; Lyons, M. E. G. Redox and Electrochemical Water Splitting Catalytic Properties of Hydrated Metal Oxide Modified Electrodes. Phys. Chem. Chem. Phys. 2013, 15, 13737-13783.

(61) Lazarides, T.; McCormick, T.; Du, P.; Luo, G.; Lindley, B.; Eisenberg, R. Making Hydrogen from Water Using a Homogeneous System without Noble Metals. J. Am. Chem. Soc. 2009, 131, 9192-9194.

(62) Han, Z.; Shen, L.; Brennessel, W. W.; Holland, P. L.; Eisenberg, R. Nickel Pyridinethiolate Complexes as Catalysts for the Light-Driven Production of Hydrogen from Aqueous Solutions in Noble-Metal-Free Systems. J. Am. Chem. Soc. 2013, 135, 14659-14669.

(63) Han, Z.; Eisenberg, R. Fuel from Water: The Photochemical Generation of Hydrogen from Water. Acc. Chem. Res. 2014, 47, 2537-2544.

(64) Varma, S.; Castillo, C. E.; Stoll, T.; Fortage, J.; Blackman, A. G.; Molton, F.; 
Deronzier, A.; Collomb, M.-N. Efficient Photocatalytic Hydrogen Production in Water Using a cobalt(III) Tetraaza-Macrocyclic Catalyst: Electrochemical Generation of the Low-Valent Co(I) Species and Its Reactivity toward Proton Reduction. Phys. Chem. Chem. Phys. 2013, 15, 17544-17552.

(65) Martindale, B. C. M.; Hutton, G. M.; Caputo, C.; Reisner, E. Solar Hydrogen Production Using Carbon Quantum Dots and a Molecular Nickel Catalyst. J. Am. Chem. Soc. 2015, 137, 6018-6026.

(66) Thoi, V. S.; Sun, Y.; Long, J. R.; Chang, C. J. Complexes of Earth-Abundant Metals for Catalytic Electrochemical Hydrogen Generation under Aqueous Conditions. Chem. Soc. Rev. 2013, 42, 2388-2400.

(67) McKone, J. R.; Marinescu, S. C.; Brunschwig, B. S.; Winkler, J. R.; Gray, H. B. Earth-Abundant Hydrogen Evolution Electrocatalysts. Chem. Sci. 2014, 5, 865878.

(68) Artero, V.; Chavarot-Kerlidou, M.; Fontecave, M. Splitting Water with Cobalt. Angew. Chemie - Int. Ed. 2011, 50, 7238-7266.

(69) Artero, V.; Fontecave, M. Some General Principles for Designing Electrocatalysts with Hydrogenase Activity. Coord. Chem. Rev. 2005, 249, 1518-1535.

(70) Darensbourg, M. Y.; Lyon, E. J.; Smee, J. J. The Bio-Organometallic Chemistry of Active Site Iron in Hydrogenases. Coord. Chem. Rev. 2000, 206-207, 533-561.

(71) Sun, Y.; Bigi, J. P.; Piro, N. A.; Tang, M. L.; Long, J. R.; Chang, C. J. Molecular Cobalt Pentapyridine Catalysts for Generating Hydrogen from Water. J. Am. 
Chem. Soc. 2011, 133, 9212-9215.

(72) King, A. E.; Surendranath, Y.; Piro, N. A.; Bigi, J. P.; Long, J. R.; Chang, C. J. A Mechanistic Study of Proton Reduction Catalyzed by a Pentapyridine Cobalt Complex: Evidence for Involvement of an Anation-Based Pathway. Chem. Sci. 2013, $4,1578$.

(73) Nippe, M.; Khnayzer, R. S.; Panetier, J. A.; Zee, D. Z.; Olaiya, B. S.; HeadGordon, M.; Chang, C. J.; Castellano, F. N.; Long, J. R. Catalytic Proton Reduction with Transition Metal Complexes of the Redox-Active Ligand bpy2PYMe. Chem. Sci. 2013, 4, 3934.

(74) Stubbert, B. D.; Peters, J. C.; Gray, H. B. Rapid Water Reduction to H 2 Catalyzed by a Cobalt Bis(iminopyridine) Complex. J. Am. Chem. Soc. 2011, 133, 1807018073.

(75) Helm, M. L.; Stewart, M. P.; Bullock, M.; Dubois, M. R.; Dubois, D. L. A Synthetic Nickel Electrocatalyst. Science (80-. ). 2011, 333, 863-866.

(76) Raugei, S.; Helm, M. L.; Hammes-Schiffer, S.; Appel, A. M.; O’Hagan, M.; Wiedner, E. S.; Bullock, R. M. Experimental and Computational Mechanistic Studies Guiding the Rational Design of Molecular Electrocatalysts for Production and Oxidation of Hydrogen. Inorg. Chem. 2016, 55, 445-460.

(77) Bhattacharjee, A.; Andreiadis, E. S.; Chavarot-Kerlidou, M.; Fontecave, M.; Field, M. J.; Artero, V. A Computational Study of the Mechanism of Hydrogen Evolution by Cobalt(diimine-Dioxime) Catalysts. Chem. a Eur. J. 2013, 19, 
$15166-15174$.

(78) Gao, H.; Huang, J.; Chen, L.; Liu, R.; Chen, J. Synthesis, Characterization and Computational Study of Heterobimetallic CoFe Complexes for Mimicking Hydrogenase. RSC Adv. 2013, 3, 3557.

(79) Hammes-Schiffer, S. Proton-Coupled Electron Transfer: Moving Together and Charging Forward. J. Am. Chem. Soc. 2015, 137, 8860-8871.

(80) Solis, B. H.; Hammes-Schiffer, S. Theoretical Analysis of Mechanistic Pathways for Hydrogen Evolution Catalyzed by Cobaloximes; 2011; Vol. 50.

(81) Hammes-Schiffer, S. Proton-Coupled Electron Transfer: Classification Scheme and Guide to Theoretical Methods. Energy Environ. Sci. 2012, 5, 7696-7703.

(82) Solis, B. H.; Hammes-Schiffer, S. Computational Study of Anomalous Reduction Potentials for Hydrogen Evolution Catalyzed by Cobalt Dithiolene Complexes. $J$. Am. Chem. Soc. 2012, 134, 15253-15256.

(83) Lim, C. H.; Holder, A. M.; Musgrave, C. B. Mechanism of Homogeneous Reduction of $\mathrm{CO} 2$ by Pyridine: Proton Relay in Aqueous Solvent and Aromatic Stabilization. J. Am. Chem. Soc. 2013, 135, 142-154.

(84) Liu, S.; Ess, D. H.; Schauer, C. K. Density Functional Reactivity Theory Characterizes Charge Separation Propensity in Proton-Coupled Electron Transfer Reactions. J. Phys. Chem. A 2011, 115, 4738-4742.

(85) Savéant, J.-M. Molecular Catalysis of Electrochemical Reactions. Mechanistic Aspects. Chem. Rev. 2008, 108, 2348-2378. 
(86) Rountree, E. S.; McCarthy, B. D.; Eisenhart, T. T.; Dempsey, J. L. Evaluation of Homogeneous Electrocatalysts by Cyclic Voltammetry. Inorg. Chem. 2014.

(87) Elgrishi, N.; McCarthy, B. D.; Rountree, E. S.; Dempsey, J. L. Reaction Pathways of Hydrogen-Evolving Electrocatalysts: Electrochemical and Spectroscopic Studies of Proton-Coupled Electron Transfer Processes. ACS Catal. 2016, 36443659.

(88) Dempsey, J. L.; Winkler, J. R.; Gray, H. B. Kinetics of Electron Transfer Reactions of H 2 -Evolving Cobalt Diglyoxime Catalysts. J. Am. Chem. Soc. 2010, 91125, 1060-1065.

(89) Han, Z.; McNamara, W. R.; Eum, M.-S.; Holland, P. L.; Eisenberg, R. A Nickel Thiolate Catalyst for the Long-Lived Photocatalytic Production of Hydrogen in a Noble-Metal-Free System. Angew. Chem. Int. Ed. Engl. 2012, 51, 1667-1670.

(90) Fox, M. A.; Bard, A. J. Artificial Photosynthesis: Solar Splitting of Water to Hydrogen and Oxygen. Acc. Chem. Res. 1995, 28, 141-145.

(91) Eckenhoff, W. T.; Eisenberg, R. Molecular Systems for Light Driven Hydrogen Production. Dalton Trans. 2012, 41, 13004-13021.

(92) Kudo, A.; Miseki, Y. Heterogeneous Photocatalyst Materials for Water Splitting. Chem. Soc. Rev. 2009, 38, 253-278.

(93) Chen, X.; Shen, S.; Guo, L.; Mao, S. S. Semiconductor-Based Photocatalytic Hydrogen Generation. Chem. Rev. 2010, 110, 6503-6570.

(94) Maeda, K.; Domen, K. Photocatalytic Water Splitting: Recent Progress and Future 
Challenges. J. Phys. Chem. Lett. 2010, 1, 2655-2661.

(95) Amouyal, E. Photochemical Production of Hydrogen and Oxygen from Water: A Review and State of the Art. Sol. Energy Mater. Sol. Cells 1995, 38, 249-276.

(96) Housecroft, C. E.; Sharpe, A. G. Inorganic Chemistry, 3rd ed.; Pearson Education Limited: Essex, 2008.

(97) Germanenko, I. N.; Li, S.; El-shall, M. S.; Commonwealth, V.; Uni, V. Decay Dynamics and Quenching of Photoluminescence from Silicon Nanocrystals by Aromatic Nitro Compounds. J. Phys. Chem. B 2006, 59-66.

(98) Song, J. H.; Sailor, M. J. Quenching of Photoluminescence from Porous Silicon by Aromatic Molecules. 1997, 7863, 7381-7385.

(99) Gonzalez, C. M.; Iqbal, M.; Dasog, M.; Piercey, D. G.; Lockwood, R.; Klapötke, T. M.; Veinot, J. G. C. Detection of High-Energy Compounds Using Photoluminescent Silicon Nanocrystal Paper Based Sensors. Nanoscale 2014, $2608-2612$.

(100) Content, S.; Trogler, W. C.; Sailor, M. J. Detection of Nitrobenzene, DNT , and TNT Vapors by Quenching of Porous Silicon Photoluminescence. Chem. Eur. J. 2000, 6, 2205-2213.

(101) Kagalwala, H. N.; Gottlieb, E.; Li, G.; Li, T.; Jin, R.; Bernhard, S. Photocatalytic Hydrogen Generation System Using a Nickel-Thiolate Hexameric Cluster. Inorg. Chem. 2013, 52, 9094-9101.

(102) McCormick, T. M.; Calitree, B. D.; Orchard, A.; Kraut, N. D.; Bright, F. V; Detty, 
M. R.; Eisenberg, R. Reductive Side of Water Splitting in Artificial Photosynthesis: New Homogeneous Photosystems of Great Activity and Mechanistic Insight. J. Am. Chem. Soc. 2010, 132, 15480-15483.

(103) Rehm, J. M.; Mclendon, G. L.; Fauchet, P. M. Conduction and Valence Band Edges of Porous Silicon Determined by Electron Transfer. J. 1996, 7863, 44904491.

(104) Esswein, A. J.; Nocera, D. G. Hydrogen Production by Molecular Photocatalysis. Chem. Rev. 2007, 107, 4022-4047.

(105) Fuller, Z. J.; Bare, W. D.; Kneas, K.; Xu, W. Y.; Demas, J. N.; DeGraff, B. Photostability of Luminescent ruthenium(II) Complexes in Polymers and in Solution. Anal. Chem. 2003, 75, 2670-2677.

(106) Magde, D.; Wong, R.; Seybold, P. G. Fluorescence Quantum Yields and Their Relation to Lifetimes of Rhodamine $6 \mathrm{G}$ and Fluorescein in Nine Solvents: Improved Absolute Standards for Quantum Yields. Photochem. Photobiol. 2002, $75,327-334$.

(107) Konishi, T.; Ikeda, A.; Asai, M.; Hatano, T.; Shinkai, S.; Fujitsuka, M.; Ito, O.; Tsuchiya, Y.; Kikuchi, J. Improvement of Quantum Yields for Photoinduced Energy/Electron Transfer by Isolation of Self-Aggregative Zinc Tetraphenyl Porphyrin-Pendant Polymer Using Cyclodextrin-Inclusion in Aqueous Soultion. Fullerenes Nanotub. Build. Blocks Next Gener. Nanodevices 2003, 2003-15, 6578. 
(108) Islam, S. D.; Konishi, T.; Fujitsuka, M.; Ito, O.; Nakamura, Y.; Usui, Y. Photosensitized Reduction of Methyl Viologen Using Eosin-Y in Presence of a Sacrificial Electron Donor in Water-Alcohol Mixture. Photochem. Photobiol. 2000, 71, 675-680.

(109) Suzuki, K.; Kobayashi, A.; Kaneko, S.; Takehira, K.; Yoshihara, T.; Ishida, H.; Shiina, Y.; Oishi, S.; Tobita, S. Reevaluation of Absolute Luminescence Quantum Yields of Standard Solutions Using a Spectrometer with an Integrating Sphere and a Back-Thinned CCD Detector. Phys. Chem. Chem. Phys. 2009, 11, 9850.

(110) Shaner, M. R.; Fountaine, K. T.; Ardo, S.; Coridan, R. H.; Atwater, H. a.; Lewis, N. S. Photoelectrochemistry of Core-shell Tandem Junction $\mathrm{N}-\mathrm{p}^{+}-\mathrm{Si} / \mathrm{n}-\mathrm{WO}{ }_{3}$ Microwire Array Photoelectrodes. Energy Environ. Sci. 2014, 7, 779-790.

(111) Liu, G.; Wang, T.; Zhang, H.; Meng, X.; Hao, D.; Chang, K.; Li, P.; Kako, T.; Ye, J. Nature-Inspired Environmental “ Phosphorylation ” Boosts Photocatalytic H 2 Production over Carbon Nitride Nanosheets under Visible-Light Irradiation Angewandte. Agewandte 2015, 54, 1-6.

(112) Demchenko, A. P.; Dekaliuk, M. O. Novel Fluorescent Carbonic Nanomaterials for Sensing and Imaging. Methods Appl. Fluoresc. 2013, 1, 042001-0420018.

(113) Zhuo, S.; Shao, M.; Lee, S. T. Upconversion and Downconversion Fluorescent Graphene Quantum Dots: Ultrasonic Preparation and Photocatalysis. ACS Nano 2012, 6, 1059-1064.

(114) Zhang, X.; Huang, H.; Liu, J.; Liu, Y.; Kang, Z. Carbon Quantum Dots Serving as 
Spectral Converters through Broadband Upconversion of near-Infrared Photons for Photoelectrochemical Hydrogen Generation. J. Mater. Chem. A 2013, 1, 1152911533.

(115) Shen, J.; Zhu, Y.; Chen, C.; Yang, X.; Li, C. Facile Preparation and Upconversion Luminescence of Graphene Quantum Dots. Chem. Commun. 2011, 47, 2580-2582.

(116) Liang, Q.; Ma, W.; Shi, Y.; Li, Z.; Yang, X. Easy Synthesis of Highly Fluorescent Carbon Quantum Dots from Gelatin and Their Luminescent Properties and Applications. Carbon N. Y. 2013, 60, 421-428.

(117) Yu, X.; Liu, R.; Zhang, G.; Cao, H. Carbon Quantum Dots as Novel Sensitizers for Photoelectrochemical Solar Hydrogen Generation and Their Size-Dependent Effect. Nanotechnology 2013, 24, 335401-335408.

(118) Yu, H.; Zhao, Y.; Zhou, C.; Shang, L.; Peng, Y.; Cao, Y.; Wu, L.-Z.; Tung, C.-H.; Zhang, T. Carbon Quantum dots/TiO2 Composites for Efficient Photocatalytic Hydrogen Evolution. J. Mater. Chem. A 2014, 2, 3344-3351.

(119) Fan, W.; Bai, H.; Shi, W. Semiconductors with NIR Driven Upconversion Performance for Photocatalysis and Photoelectrochemical Water Splitting. CrystEngComm 2014, 16, 3059-3067.

(120) Shen, J.; Zhu, Y.; Yang, X.; Zong, J.; Zhang, J.; Li, C. One-Pot Hydrothermal Synthesis of Graphene Quantum Dots Surface-Passivated by Polyethylene Glycol and Their Photoelectric Conversion under near-Infrared Light. New J. Chem. 2012, $36,97-101$. 
(121) Virca, C. N.; Mccormick, T. M. DFT Analysis into the Intermediates of Nickel Pyridine Thiolate Catalyzed Proton Reduction Carolyn N. Virca and Theresa M. McCormick: Supporting Information. Dalt. Trans. 2015, 1-28.

(122) M. J. Frisch, G. W. Trucks, H. B. Schlegel, G. E. Scuseria, M. A. Robb, J. R. Cheeseman, G. Scalmani, V. Barone, B. Mennucci, G. A. Petersson, H. Nakatsuji, M. Caricato, X. Li, H. P. Hratchian, A. F. Izmaylov, J. Bloino, G. Zheng, J. L. Sonnenberg, M. Had, and D. J. F. Gaussian 09 Revision. Gaussian, Inc.

(123) Becke, A. D. Density-Functional Exchange-Energy Approximation with Correct Asymptotic-Behavior. Phys. Rev. 1988, A, 3098-3100.

(124) Miehlich, B.; Savin, A.; Stoll, H.; Preuss, H. Results Obtained with the Correlation-Energy Density Functionals of Becke and Lee, Yang and Parr. Chem. Phys. Lett 1989, 157, 200-206.

(125) Perdew, J. P. Density-Functional Approximation for the Correlation Energy of the Inhomogeneous Electron Gas. Phys. Rev. B 1986, 33, 8822-8824.

(126) Lee, C.; Yang, W.; Parr, R. G. Development of the Colle-Salvetti CorrelationEnergy Formula into a Functional of the Electron Density. Physical Review B, 1988, 37, 785-789.

(127) Solis, B. H.; Hammes-Schiffer, S. Proton-Coupled Electron Transfer in Molecular Electrocatalysis: Theoretical Methods and Design Principles. Inorg. Chem. 2014, $53,6427-6443$.

(128) Chen, S.; Raugei, S.; Rousseau, R.; Dupuis, M.; Bullock, R. M. Homogeneous Ni 
Catalysts for H2 Oxidation and Production: An Assessment of Theoretical Methods, from Density Functional Theory to Post Hartree-Fock Correlated WaveFunction Theory. J. Phys. Chem. A 2010, 114, 12716-12724.

(129) Barone, V.; Cossi, M. Quantum Calculation of Molecular Energies and Energy Gradients in Solution by a Conductor Solvent Model. J. Phys. Chem. A 1998, 102, 1995-2001.

(130) Cossi, M.; Rega, N.; Scalmani, G.; Barone, V. Energies, Structures, and Electronic Properties of Molecules in Solution with the C-PCM Solvation Model. J. Comp. Chem. 2003, 24, 669-681.

(131) Schn, P. E. N.; Schn, P. N.; Rosenfield, S. G.; Berends, H. P.; Gelmini, L.; Stephan, D. W.; Mascharak, P. K. New Octahedral Thiolato Complexes of Divalent Nickel : Syntheses, Structures, and. Inorg. Chem. 1987, 2792-2797.

(132) Qi, X.; Liu, L.; Fu, Y.; Guo, Q. Ab Initio Calculations of P K a Values of Transition-Metal Hydrides in Acetonitrile. Organometallics 2006, 25, 5879-5886.

(133) Fourmond, V.; Jacques, P. A.; Fontecave, M.; Artero, V. H2evolution and Molecular Electrocatalysts: Determination of Overpotentials and Effect of Homoconjugation. Inorg. Chem. 2010, 49, 10338-10347.

(134) Felton, G. A. N.; Glass, R. S.; Lichtenberger, D. L.; Evans, D. H. Iron-Only Hydrogenase Mimics. Thermodynamic Aspects of the Use of Electrochemistry to Evaluate Catalytic Efficiency for Hydrogen Generation. Inorg. Chem. 2006, 45, $9181-9184$. 
(135) Roberts, J. A. S.; Bullock, R. M. Direct Determination of Equilibrium Potentials for Hydrogen Oxidation/production by Open Circuit Potential Measurements in Acetonitrile. Inorg. Chem. 2013, 52, 3823-3835.

(136) Savéant, J. M.; Vianello, E. Potential-Sweep Voltammetry: General Theory of Chemical Polarization. Electrochim. Acta 1967, 12, 629-646.

(137) Saveant, J. M.; Vianello, E. Potential-Sweep Chronoamperometry: Kinetic Currents for First-Order Chemical Reaction Parallel to Electron-Transfer Process (Catalytic Currents). Electrochim. Acta 1965, 10, 905-920.

(138) Saveant, J. M.; Su, K. B. Homogenous Redox Catalysis of Electrochemical Reaction. J. Electroanal. Chem 1984, 171, 341-349.

(139) Hu, X.; Brunschwig, B. S.; Peters, J. C. Electrocatalytic Hydrogen Evolution at Low Overpotentials by Cobalt Macrocyclic Glyoxime and Tetraimine Complexes. J. Am. Chem. Soc. 2007, 129, 8988-8998.

(140) Bigi, J. P.; Hanna, T. E.; Harman, W. H.; Chang, A.; Chang, C. J. Electrocatalytic Reduction of Protons to Hydrogen by a Water-Compatible Cobalt Polypyridyl Platform. Chem. Commun. 2010, 46, 958-960.

(141) Kilgore, U. J.; Roberts, J. A. S.; Pool, D. H.; Appel, A. M.; Stewart, M. P.; Dubois, M. R.; Dougherty, W. G.; Kassel, W. S.; Bullock, R. M.; Dubois, D. L. [ Ni ( P $\mathrm{Ph} 2 \mathrm{~N}$ C6H4X2 ) 2 ] 2 p Complexes as Electrocatalysts for H 2 Production : Effect of Substituents, Acids, and Water on Catalytic Rates. J. Am. Chem. Soc. 2011, $133,5861-5872$. 
(142) Appel, A. M.; Pool, D. H.; O’Hagan, M.; Shaw, W. J.; Yang, J. Y.; Rakowski Dubois, M.; Dubois, D. L.; Bullock, R. M. [Ni(PPh2NBn2) 2(CH3CN)]2+ as an Electrocatalyst for H 2 Production: Dependence on Acid Strength and Isomer Distribution. ACS Catal. 2011, 1, 777-785.

(143) Stubbert, B. D.; Peters, J. C.; Gray, H. B. Rapid Water Reduction to H2 Catalyzed by a Cobalt Bis(iminopyridine) Complex. J. Am. Chem. Soc. 2011, 133, 1807018073.

(144) Helm, M. L.; Stewart, M. P.; Bullock, R. M.; Dubois, M. R.; Dubois, D. L. A Synthetic Nickel Electrocatalyst with a Turnover Frequency Above 100,000 S-1 for H2 Production. Science (80-. ). 2011, 863-866.

(145) Mccrory, C. C. L.; Uyeda, C.; Peters, J. C. Electrocatalytic Hydrogen Evolution in Acidic Water with Molecular Cobalt Tetraazamacrocycles. 2012.

(146) Rabek, J. F. Experimental Methods in Photochemistry and Photophysics Part 2. In; John Wiley \& Sons Ltd.: Belfast, 1982; pp 944-946.

(147) Complexes, T. N.; Gill, B. N. S.; Nyholm, R. S. Gill and Nyholm. 3997802. Complex Halides.

(148) Rosenfield, S. G.; Berends, H. P.; Gelmini, L.; Stephan, D. W.; Mascharak, P. K. New Octahedral Thiolato Complexes of Divalent Nickel: Syntheses, Structures, and Properties of (Et4N) and (Ph4P). CH3CN. Inorg. Chem. 1987, 26, 2792-2797.

(149) Guo, C. X.; Zhao, D.; Zhao, Q.; Wang, P.; Lu, X. Na+-Functionalized Carbon Quantum Dots: A New Draw Solute in Forward Osmosis for Seawater 
Desalination. Chem. Commun. 2014, 50, 7318-7321.

(150) Chen, Y.; Peng, D.-L.; Lin, D.; Luo, X. Preparation and Magnetic Properties of Nickel Nanoparticles via the Thermal Decomposition of Nickel Organometallic Precursor in Alkylamines. Nanotechnology 2007, 18, 1-8.

(151) Cao, S.; Wang, C.-J.; Lv, X.-J.; Chen, Y.; Fu, W.-F. A Highly Efficient Photocatalytic H2 Evolution System Using Colloidal CdS Nanorods and Nickel Nanoparticles in Water under Visible Light Irradiation. Appl. Catal. B Environ. 2015, 162, 381-391.

(152) Du, P.; Eisenberg, R. Catalysts Made of Earth-Abundant Elements (Co, Ni, Fe) for Water Splitting: Recent Progress and Future Challenges. Energy Environ. Sci. 2012, 5, 6012 .

(153) Das, A.; Han, Z.; Brennessel, W. W.; Holland, P. L.; Eisenberg, R. Nickel Complexes for Robust Light-Driven and Electrocatalytic Hydrogen Production from Water. ACS Catal. 2015, 1397-1406.

(154) James, T. L.; Cai, L.; Muetterties, M. C.; Holm, R. H. Dihydrogen Evolution by Protonation Reactions of Nickel(I). Inorg. Chem. 1996, 35, 4148-4161.

(155) Han, Z.; Qiu, F.; Eisenberg, R.; Holland, P. L.; Krauss, T. D. Robust Photogeneration of H2 in Water Using Semiconductor Nanocrystals and a Nickel Catalyst. Science 2012, 338, 1321-1324.

(156) McLaughlin, M. P.; McCormick, T. M.; Eisenberg, R.; Holland, P. L. A Stable Molecular Nickel Catalyst for the Homogeneous Photogeneration of Hydrogen in 
Aqueous Solution. Chem. Commun. 2011, 47, 7989-7991.

(157) Jacques, P.-A.; Artero, V.; Pécaut, J.; Fontecave, M. Cobalt and Nickel DiimineDioxime Complexes as Molecular Electrocatalysts for Hydrogen Evolution with Low Overvoltages. Proc. Natl. Acad. Sci. U. S. A. 2009, 106, 20627-20632.

(158) Cherdo, S.; Ghachtouli, S. El; Sircoglou, M.; Brisset, F.; Orio, M.; Aukauloo, A. A Nickel Dimethyl Glyoximato Complex to Form Nickel Based Nanoparticles for Electrocatalytic H2 Production. Chem. Commun. 2014, 50, 13514-13516.

(159) Mondal, B.; Sengupta, K.; Rana, A.; Mahammed, A.; Botoshansky, M.; Dey, S. G.; Gross, Z.; Dey, A. Cobalt Corrole Catalyst for E Ffi Cient Hydrogen Evolution Reaction from H $2 \mathrm{O}$ under Ambient Conditions : Reactivity, Spectroscopy, and Density Functional Theory Calculations. Inorg. Chem. 2013, 52, 3381-3387.

(160) Gan, L.; Groy, T. L.; Tarakeshwar, P.; Mazinani, S. K. S.; Shearer, J.; Mujica, V.; Jones, A. K. A Nickel Phosphine Complex as a Fast and Efficient Hydrogen Production Catalyst. J. Am. Chem. Soc. 2015.

(161) Raugei, S.; DuBois, D. L.; Rousseau, R.; Chen, S.; Ho, M.-H.; Bullock, R. M.; Dupuis, M. Toward Molecular Catalysts by Computer. Acc. Chem. Res. 2015, 150109134700000 .

(162) Hammes-Schiffer, S. Theory of Proton-Coupled Electron Transfer in Energy Conversion Processes. Acc. Chem. Res. 2009, 42, 1881-1889.

(163) Wiedner, E. S.; Appel, A. M.; Dubois, D. L.; Bullock, R. M. Thermochemical and Mechanistic Studies of Electrocatalytic Hydrogen Production by Cobalt 
Complexes Containing Pendant Amines. Inorg. Chem. 2013, 52, 14391-14403.

(164) Liao, R.-Z.; Wang, M.; Sun, L.; Siegbahn, P. E. M. The Mechanism of Hydrogen Evolution in $\mathrm{Cu}$ (bztpen)-Catalysed Water Reduction: A DFT Study. Dalt. Trans. 2015, 9736-9739.

(165) Muckerman, J. T.; Fujita, E. Theoretical Studies of the Mechanism of Catalytic Hydrogen Production by a Cobaloxime. Chem. Commun. 2011, 47, 12456-12458.

(166) Solis, B. H.; Yu, Y.; Hammes-Schiffer, S. Effects of Ligand Modification and Protonation on Metal Oxime Hydrogen Evolution Electrocatalysts. Inorg. Chem. 2013, 52, 6994-6999.

(167) Hagan, M. O.; Ho, M.; Yang, J. Y.; Appel, A. M.; Dubois, M. R.; Raugei, S.; Shaw, W. J.; Dubois, D. L.; Bullock, R. M. Proton Delivery and Removal in [Ni(PR2NR' 2)2]2+ Hydrogen Production and Oxidation Catalysts. J. Am. Chem. Soc. 2012, 134, 19409-19424.

(168) Fernandez, L. E.; Horvath, S.; Hammes-Schiffer, S. Theoretical Analysis of the Sequential Proton-Coupled Electron Transfer Mechanisms for H 2 Oxidation and Production Pathways Catalyzed by Nickel Molecular Electrocatalysts. J. Phys. Chem. C 2012, 116, 3171-3180.

(169) Chen, S.; Ho, M. H.; Bullock, R. M.; Dubois, D. L.; Dupuis, M.; Rousseau, R.; Raugei, S. Computing Free Energy Landscapes: Application to Ni-Based Electrocatalysts with Pendant Amines for $\mathrm{H} 2$ Production and Oxidation. ACS Catal. 2014, 4, 229-242. 
(170) Petrou, A. L.; Koutselos, A. D.; Wahab, H. S.; Clegg, W.; Harrington, R. W.; Henderson, R. a. Kinetic and Theoretical Studies on the Protonation of [Ni(2$\mathrm{SC} 6 \mathrm{H} 4 \mathrm{~N})\{\mathrm{PhP}(\mathrm{CH} 2 \mathrm{CH} 2 \mathrm{PPh} 2) 2\}]+$ : Nitrogen versus Sulfur as the Protonation Site. Inorg. Chem. 2011, 50, 847-857.

(171) Cramer, C. J.; Truhlar, D. G. Density Functional Theory for Transition Metals and Transition Metal Chemistry. Phys. Chem. Chem. Phys. 2009, 11, 10757-10816.

(172) Cano, J.; Ruiz, E.; Alvarez, S.; Verdaguer, M. Spin Density Distribution in Transition Metal Complexes: Some Thoughts and Hints. Comments Inorg. Chem. 1998, 20, 27-56.

(173) Luca, O. R.; Blakemore, J. D.; Konezny, S. J.; Praetorius, J. M.; Schmeier, T. J.; Hunsinger, G. B.; Batista, V. S.; Brudvig, G. W.; Hazari, N.; Crabtree, R. H. Organometallic Ni Pincer Complexes for the Electrocatalytic Production of Hydrogen. Inorg. Chem. 2012, 51, 8704-8709.

(174) Lyaskovskyy, V.; Bruin, B. De. Redox Non-Innocent Ligands: Versatile New Tools to Control Catalytic Reactions. ACS Catal. 2012, 2, 270-279.

(175) Ciancanelli, R.; Noll, B. C.; DuBois, D. L.; Rakowski DuBois, M. Comprehensive Thermodynamic Characterization of the Metal-Hydrogen Bond in a Series of Cobalt-Hydride Complexes. J. Am. Chem. Soc. 2002, 124, 2984-2992.

(176) Hammes-Schiffer, S.; Soudackov, A. V. Proton-Coupled Electron Transfer in Solution, Proteins, and Electrochemistry. J. Phys. Chem. B 2008, 112, 1410814123. 
(177) Wayner, D. D. M.; Parker, V. D. Bond Energies in Solution from Electrode Potentials and Thermochemical Cycles. A Simplified and General Approach1. Acc. Chem. Res. 1993, 26, 287-294.

(178) Chen, S.; Rousseau, R.; Raugei, S.; Dupuis, M.; DuBois, D. L.; Bullock, R. M. Comprehensive Thermodynamics of Nickel Hydride Bis(diphosphine) Complexes: A Predictive Model through Computations. Organometallics 2011, 30, 6108-6118.

(179) Rosser, T. E.; Gross, M. A.; Lai, Y.-H.; Reisner, E. Precious-Metal Free Photoelectrochemical Water Splitting with Immobilised Molecular Ni and Fe Redox Catalysts. Chem. Sci. 2016, 7, 4024-4035.

(180) Chen, S.; Ho, M.; Bullock, R. M.; Daniel, L.; Dupuis, M.; Rousseau, R.; Raugei, S. Computing Free Energy Landscapes : Application to Ni-Based Electrocatalysts with Pendant Amines for H2 Production and Oxidation Computing Free Energy Landscapes: Application to Ni-Based Electrocatalysts with Pendant Amines for H2 Production and Oxidation. ACS Catal. 2013, 4, 229-242.

(181) Hammes-Schiffer, S. Catalysts by Design: The Power of Theory. Acc. Chem. Res. 2017, 50, 561-566.

(182) Solis, B. H.; Hammes-Schiffer, S. Substituent Effects on Cobalt Diglyoxime Catalysts for Hydrogen Evolution. J. Am. Chem. Soc. 2011, 133, 19036-19039.

(183) Raugei, S.; DuBois, D. L.; Rousseau, R.; Chen, S.; Ho, M.-H.; Bullock, R. M.; Dupuis, M. Toward Molecular Catalysts by Computer. Acc. Chem. Res. 2015, 48, $248-255$. 
(184) Anson, C. W.; Ghosh, S.; Hammes-Schiffer, S.; Stahl, S. S. Co(salophen)Catalyzed Aerobic Oxidation of P-Hydroquinone: Mechanism and Implications for Aerobic Oxidation Catalysis. J. Am. Chem. Soc. 2016, 138, 4186-4193.

(185) Panetier, J. A.; Letko, C. S.; Tilley, T. D.; Head-Gordon, M. Computational Characterization of Redox Non-Innocence in Cobalt-Bis(Diaryldithiolene)Catalyzed Proton Reduction. J. Chem. Theory Comput. 2016, 12, 223-230.

(186) De Proft, F.; Forquet, V.; Ourri, B.; Chermette, H.; Geerlings, P.; Morell, C. Investigation of Electron Density Changes at the Onset of a Chemical Reaction Using the State-Specific Dual Descriptor from Conceptual Density Functional Theory. Phys. Chem. Chem. Phys. 2015, 17, 9359-9368.

(187) Tognetti, V.; Morell, C.; Joubert, L. Quantifying Electro/nucleophilicity by Partitioning the Dual Descriptor. J. Comput. Chem. 2015, 36, 649-659.

(188) Virca, C. N.; McCormick, T. DFT Analysis into the Intermediates of Nickel Pyridinethiolate Catalysed Proton Reduction. Dalt. Trans. 2015.

(189) Hansch, C.; Leo, a; Taft, R. W. A Survey of Hammett Substituent Constants and Resonance and Field Parameters. Chem. Rev. 1991, 91, 165-195.

(190) O’Hagan, M.; Shaw, W. J.; Raugei, S.; Chen, S.; Yang, J. Y.; Kilgore, U. J.; Dubois, D. L.; Bullock, R. M. Moving Protons with Pendant Amines: Proton Mobility in a Nickel Catalyst for Oxidation of Hydrogen. J. Am. Chem. Soc. 2011, 133, 14301-14312.

(191) Rakowski DuBois, M.; DuBois, D. L. The Roles of the First and Second 
Coordination Spheres in the Design of Molecular Catalysts for H2 Production and Oxidation. Chem. Soc. Rev. 2009, 38, 62-72.

(192) Yang, J. Y.; Bullock, R. M.; DuBois, M. R.; DuBois, D. L. Fast and Efficient Molecular Electrocatalysts for $\mathrm{H} 2$ Production: Using Hydrogenase Enzymes as Guides. MRS Bull. 2011, 36, 39-47.

(193) Goff, A. L.; Artero, V.; Jousselme, B.; Tran, P.; Guillet, N.; Metaye, R.; Fihri, A.; Palacin, S.; Fontecave, M. From Hydrogenases to Noble Metal-Free Catalytic Nanomaterials for H2 Production and Uptake. Science (80-. ). 2009, 326, 13841387.

(194) Rountree, E. S.; Martin, D. J.; Mccarthy, B. D.; Dempsey, J. L. Linear Free Energy Relationships in the Hydrogen Evolution Reaction: Kinetic Analysis of a Cobaloxime Catalyst. 2016.

(195) Wiedner, E. S.; Brown, H. J. S.; Helm, M. L. Kinetic Analysis of Competitive Electrocatalytic Pathways: New Insights into Hydrogen Production with Nickel Electrocatalysts. 2016.

(196) Costentin, C.; Savøant, J. Multielectron , Multistep Molecular Catalysis of Electrochemical Reactions: Benchmarking of Homogeneous Catalysts. 2014, $1226-1236$.

(197) Costentin, C.; Drouet, S.; Robert, M.; Save, J. Turnover Numbers, Turnover Frequencies, and Overpotential in Molecular Catalysis of Electrochemical Reactions. Cyclic Voltammetry and Preparative-Scale Electrolysis. J. Am. Chem. 
Soc. 2012, 134, 11235-11242.

(198) Solis, B. H.; Hammes-Schiffer, S. Theoretical Analysis of Mechanistic Pathways for Hydrogen Evolution Catalyzed by Cobaloximes. Inorg. Chem. 2011, 50, $11252-11262$.

(199) Gärtner, F.; Boddien, A.; Barsch, E.; Fumino, K.; Losse, S.; Junge, H.; Hollmann, D.; Brückner, A.; Ludwig, R.; Beller, M. Photocatalytic Hydrogen Generation from Water with Iron Carbonyl Phosphine Complexes: Improved Water Reduction Catalysts and Mechanistic Insights. Chem. an Eur. J. 2011, 17, 6425-6436.

(200) Kachmar, A.; Vetere, V.; Maldivi, P.; Franco, A. New Insights in the Electrocatalytic Proton Reduction and Hydrogen Oxidation by Bioinspired Catalysts: A DFT Investigation. J. Phys. Chem. A 2010, 114, 11861-11867.

(201) Poree, C.; Schoenebeck, F. A Holy Grail in Chemistry: Computational Catalyst Design: Feasible or Fiction? Acc. Chem. Res. 2017, 50, 605-608.

(202) Mavros, M. G.; Tsuchimochi, T.; Kowalczyk, T.; McIsaac, A.; Wang, L. P.; Voorhis, T. Van. What Can Density Functional Theory Tell Us about Artificial Catalytic Water Splitting? Inorg. Chem. 2014, 53, 6386-6397.

(203) Du, P.; Eisenberg, R. Catalysts Made of Earth-Abundant Elements (Co, Ni, Fe) for Water Splitting: Recent Progress and Future Challenges. Energy Environ. Sci. 2012, 5, 6012 .

(204) Mccullough, B. J.; Neyhouse, B. J.; Schrage, B. R.; Reed, D. T.; Osinski, A. J.; Ziegler, C. J.; White, T. A. Visible-Light-Driven Photosystems Using Heteroleptic 
Cu(I) Photosensitizers and Rh(III) Catalysts To Produce H 2. 2017.

(205) Morris, A. J.; Meyer, G. J.; Fujita, E. Molecular Approaches to the Photocatalytic Reduction of Carbon Dioxide for Solar Fuels. Acc. Chem. Res. 2009, 42, 19831994.

(206) Horvath, S.; Fernandez, L. E.; Appel, A. M.; Hammes-Schiffer, S. PH-Dependent Reduction Potentials and Proton-Coupled Electron Transfer Mechanisms in Hydrogen-Producing Nickel Molecular Electrocatalysts. Inorg. Chem. 2013, 52, $3643-3652$.

(207) Fernandez, L. E.; Horvath, S.; Hammes-Schiffer, S. Theoretical Analysis of the Sequential Proton-Coupled Electron Transfer Mechanisms for H 2 Oxidation and Production Pathways Catalyzed by Nickel Molecular Electrocatalysts. J. Phys. Chem. C 2012, 116, 3171-3180.

(208) Virca, C. N.; Lohmolder, J. R.; Tsang, J. B.; Davis, M. M.; McCormick, T. M. Effect of Ligand Modification on the Mechanism of Electrocatalytic Hydrogen Production by Ni(pyridinethiolate)3- Derivatives. J. Phys. Chem. A Just Accept. Manuscr. 2018.

(209) Andrieux, C. P.; Dumas-Bouchiat, J. M.; Savéant, J. M. Homogeneous Redox Catalysis of Electrochemical Reactions. Part IV. Kinetic Controls in the Homogeneous Process as Characterized by Stationary and Quasi-Stationary Electrochemical Techniques. J. Electroanal. Chem. 1980, 113, 1-18.

(210) Butler, M.; Cabrera, G. M. A Mass Spectrometry and DFT Study of Pyrithione 
Complexes with Transition Metals in the Gas Phase. J. Mass Spectrom. 2017, 52, $728-738$.

(211) Virca, C.; Winter, H.; Goforth, A. M.; Mackiewicz, M.; McCormick, T. Photocatalytic Water Reduction Using a Polymer Coated Carbon Quantum Dot Sensitizer and a Nickel Nanoparticle Catalyst. Nanotechnology 2017, 28.

(212) Berardi, S.; Drouet, S.; Francàs, L.; Gimbert-Suriñach, C.; Guttentag, M.; Richmond, C.; Stoll, T.; Llobet, A. Molecular Artificial Photosynthesis. Chem. Soc. Rev. 2014, 7501-7519.

(213) Luo, S.-P.; Mejía, E.; Friedrich, A.; Pazidis, A.; Junge, H.; Surkus, A.-E.; Jackstell, R.; Denurra, S.; Gladiali, S.; Lochbrunner, S.; Beller, M. Photocatalytic Water Reduction with Copper-Based Photosensitizers: A Noble-Metal-Free System. Angew. Chemie 2013, 125, 437-441.

(214) Xu, Y.; Xu, R. Nickel-Based Cocatalysts for Photocatalytic Hydrogen Production. Appl. Surf. Sci. 2015, 351, 779-793.

(215) Rao, H.; Yu, W.-Q.; Zheng, H.-Q.; Bonin, J.; Fan, Y.-T.; Hou, H.-W. Highly Efficient Photocatalytic Hydrogen Evolution from Nickel Quinolinethiolate Complexes under Visible Light Irradiation. J. Power Sources 2016, 324, 253-260.

(216) McConnell, I.; Li, G.; Brudvig, G. W. Energy Conversion in Natural and Artificial Photosynthesis. Chem. Biol. 2010, 17, 434-447.

(217) Gust, D.; Moore, T. A.; Moore, A. L. Solar Fuels via Artificial PhotosynthesisGust-Moore-ar900209b.pdf. 2009, 42, 1890-1898. 
(218) Nocera, D. G.; Lewis, N. S. Powering the Planet: Chemical Challegenges in Solar Energy Utilization. PNAS 2007, 104, 15729-15735.

(219) Mckone, J. R.; Lewis, N. S.; Gray, H. B. Will Solar-Driven Water-Splitting Devices See the Light of Day? Chem. Mater. 2013, 26, 407-414.

(220) Gray, H. B. Powering the Planet with Solar Fuel. Nat. Chem. 2009, 1, 7.

(221) Kantürk Figen, A.; Coşkuner Filiz, B. Hydrogen Production by the Hydrolysis of Milled Waste Magnesium Scraps in Nickel Chloride Solutions and Nickel Chloride Added in Marmara Sea and Aegean Sea Water. Int. J. Hydrogen Energy $\mathbf{2 0 1 5}, 40,16169-16177$.

(222) R. Wang, K. Pan, D. Han, J. Jiang, C. Xiang, Z. Huang, L. Zhang, X. X. SolarDriven $\mathrm{H} 2 \mathrm{O} 2$ Generation From H2O and O2 Using Earth-Abundant Mixed-Metal Oxide@Carbon Nitride Photocatalysts Authors. ChemSusChem 2016, 9, 24702479.

(223) He, W., Yang, Y., Wang, L., Yang, J., Xiang, X., Yan, D. and Li, F. Photoelectrochemical Water Oxidation Efficiency of a Core/Shell Array Photoanode Enhanced by a Dual Suppression Strategy. ChemSusChem 2015, 8, $1568-1576$.

(224) Xiang, X.; Fielden, J.; Rodríguez-Córdoba, W.; Huang, Z.; Zhang, N.; Luo, Z.; Musaev, D. G.; Lian, T.; Hill, C. L. Electron Transfer Dynamics in Semiconductor-Chromophore-Polyoxometalate Catalyst Photoanodes. J. Phys. Chem. C 2013, 117, 918-924. 
(225) He, W.; Wang, R.; Zhang, L.; Zhu, J.; Xiang, X.; Li, F. Enhanced Photoelectrochemical Water Oxidation on a BiVO 4 Photoanode Modified with Multi-Functional Layered Double Hydroxide Nanowalls. J. Mater. Chem. A 2015, 3, 17977-17982.

(226) Tang, Y.; Wang, R.; Yang, Y.; Yan, D.; Xiang, X. Highly Enhanced Photoelectrochemical Water Oxidation Efficiency Based on Triadic Quantum Dot/Layered Double Hydroxide/BiVO 4 Photoanodes. ACS Appl. Mater. Interfaces 2016, 8, 19446-19455.

(227) European Comission. Directive 2011/65/EU. Dir. 2011/65/EU.

(228) Lim, S. Y.; Shen, W.; Gao, Z. Carbon Quantum Dots and Their Applications. Chem. Soc. Rev. 2014, 44, 362-381.

(229) Wang, W.; Yu, J. C.; Shen, Z.; Chan, D. K. L.; Gu, T. G-C3N4 Quantum Dots: Direct Synthesis, Upconversion Properties and Photocatalytic Application. Chem. Commun. 2014, 50, 10148-10150.

(230) Cao, L.; Wang, X.; Meziani, M. J.; Lu, F.; Wang, H.; Luo, P. G.; Lin, Y.; Harruff, B.; Veca, L. M.; Murray, D.; Xie, S. Y.; Sun, Y. P. Carbon Dots for Multiphoton Bioimaging. J. Am. Chem. Soc. 2007, 129, 11318-11319.

(231) Yamada, Y.; Miyahigashi, T.; Kotani, H.; Ohkubo, K.; Fukuzumi, S. Photocatalytic Hydrogen Evolution with Ni Nanoparticles by Using 2-Phenyl-4-(1Naphthyl)quinolinium Ion as a Photocatalyst. Energy Environ. Sci. 2012, 5, 61116118. 
(232) Kudr, J.; Richtera, L.; Nejdl, L.; Blazkova, I.; Milosavljevic, V.; Moravec, Z.; Wawrzak, D.; Kopel, P.; Ruttkay-Nedecky, B.; Adam, V.; Kizek, R. Characterization of Carbon Dots Covered with Polyvinylpyrrolidone and Polyethylene Glycol. Int. J. Electrochem. Sci. 2015, 10, 8243-8254.

(233) Yang, Z.-C.; Li, X.; Wang, J. Intrinsically Fluorescent Nitrogen-Containing Carbon Nanoparticles Synthesized by a Hydrothermal Process. Carbon N. Y. 2011, $49,5207-5212$.

(234) Nan, F.; Kang, Z.; Wang, J.; Shen, M.; Fang, L. Carbon Quantum Dots Coated BiVO4 Inverse Opals for Enhanced Photoelectrochemical Hydrogen Generation. Appl. Phys. Lett. 2015, 106, 153901-153907.

(235) Zhu, S.; Zhang, J.; Tang, S.; Qiao, C.; Wang, L.; Wang, H.; Liu, X.; Li, B.; Li, Y.; Yu, W.; Wang, X.; Sun, H.; Yang, B. Surface Chemistry Routes to Modulate the Photoluminescence of Graphene Quantum Dots: From Fluorescence Mechanism to up-Conversion Bioimaging Applications. Adv. Funct. Mater. 2012, 22, 47324740.

(236) Martindale, B. C. M.; Hutton, G. A. M.; Caputo, C. A.; Reisner, E. Supporting Information Solar Hydrogen Production Using Carbon Quantum Dots and a Molecular Nickel Catalyst. J. Am. Chem. Soc. 2015, 137, 6018-6026.

(237) Jia, X.; Li, J.; Wang, E. One-Pot Green Synthesis of Optically pH-Sensitive Carbon Dots with Upconversion Luminescence. Nanoscale 2012, 4, 5572-5575.

(238) Mahyari, M.; Shaabani, A. Nickel Nanoparticles Immobilized on Three- 
Dimensional Nitrogen-Doped Graphene as a Superb Catalyst for the Generation of Hydrogen from the Hydrolysis of Ammonia Borane. J. Mater. Chem. A 2014, 2, $16652-16659$. 


\section{APPENDIX}

\section{ADDITIONAL EXPERIMENTAL AND COMPUTATIONAL DATA}

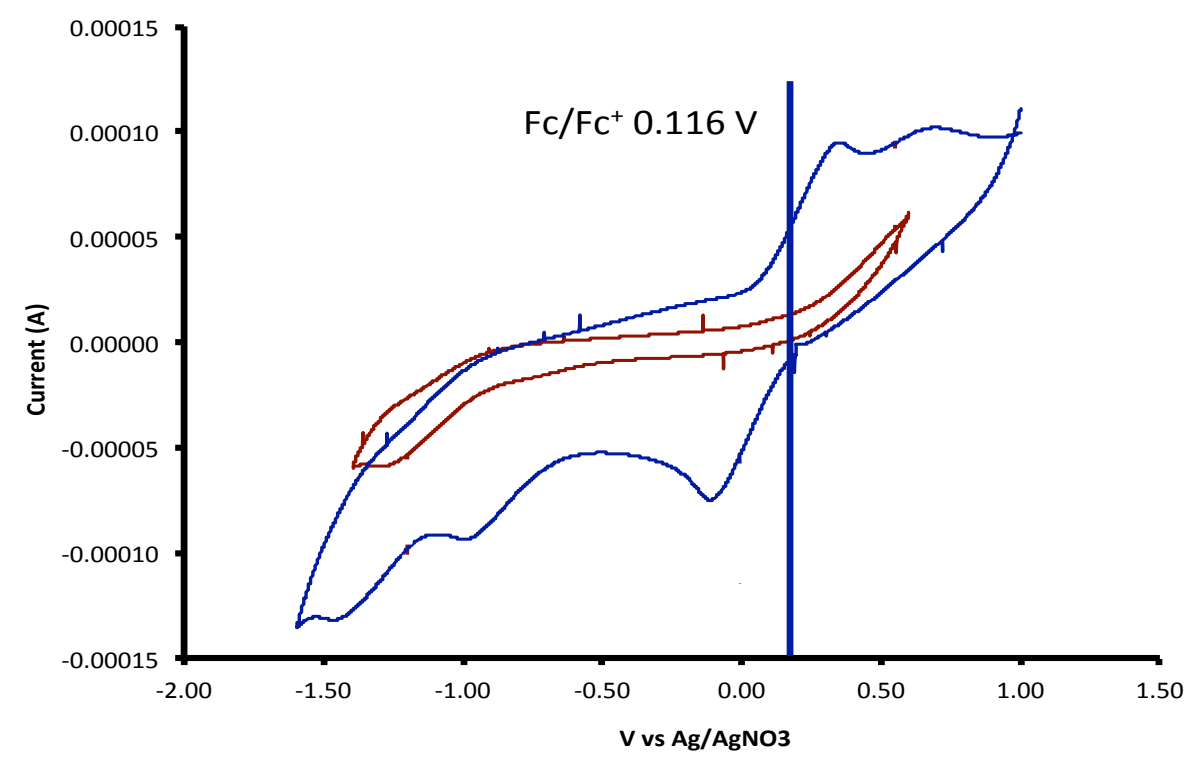

Appendix Figure 1: Cyclic voltammograms of a $1 \times 10^{-3} \mathrm{M}$ solution of $\mathrm{Ni}(\mathrm{PyS})_{3}{ }^{-}$in dry/degassed acetonitrile with TBAF without a proton source or ferrocene (red) and with both ferrocene and 4-cyanoanilinium (blue). Scan started in the negative direction at $0 \mathrm{~V}$ vs $\mathrm{Ag} / \mathrm{AgNO}_{3}$ using a $500 \mathrm{mV}$ scan rate using a glassy carbon working electrode, platinum coil counter electrode and $\mathrm{Ag} / \mathrm{AgNO}_{3}$ reference with acetonitrile solution. 

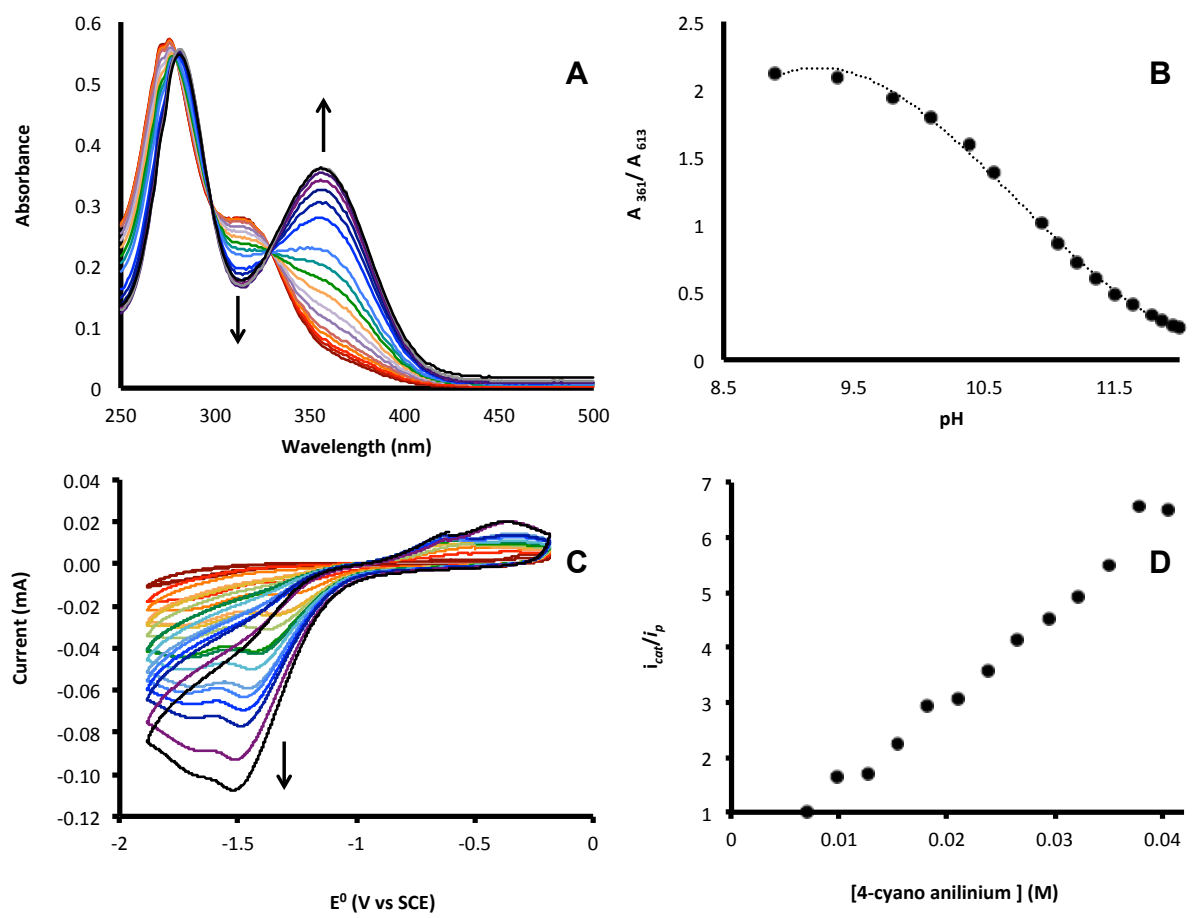

Appendix Figure 2: A) UV-vis absorbance spectra of a $2 \times 10^{-3} \mathrm{M}$ solution of $\mathrm{Ni}(3-$ $\left.\mathrm{CF}_{3} \mathrm{PyS}\right)_{3}{ }_{3}^{-}$in $1: 1 \mathrm{H}_{2} \mathrm{O} / \mathrm{EtOH}$ as it is titrated with $0.1 \mathrm{M}$ aqueous $\mathrm{HCl}$ to yield $\mathrm{Ni}(3-$ $\left.\mathrm{CF}_{3} \mathrm{PyS}\right)_{3} \mathrm{H}$. B) plot of the ratio of the absorbance at $\lambda_{\max }$ for $\mathrm{Ni}\left(3-\mathrm{CF}_{3} \mathrm{PyS}\right)_{3}{ }_{3} / \mathrm{Ni}(3-$ $\left.\mathrm{CF}_{3} \mathrm{PyS}\right)_{3} \mathrm{H}$ vs $\mathrm{pH}$. C) Cyclic voltammograms of a $1.4 \times 10^{-3} \mathrm{M} \mathrm{Ni}\left(3-\mathrm{CF}_{3} \mathrm{PyS}\right)_{3}{ }^{-}$in dry $/$ degassed acetonitrile taken at a scan rate of $500 \mathrm{mV} / \mathrm{s}$ starting at $0 \mathrm{~V}$ vs $\mathrm{Ag}^{+} / \mathrm{AgNO}_{3}$ and D) plot of $i_{\text {cat }} / i_{\mathrm{p}}$ vs [4-cyanoanilinium] 

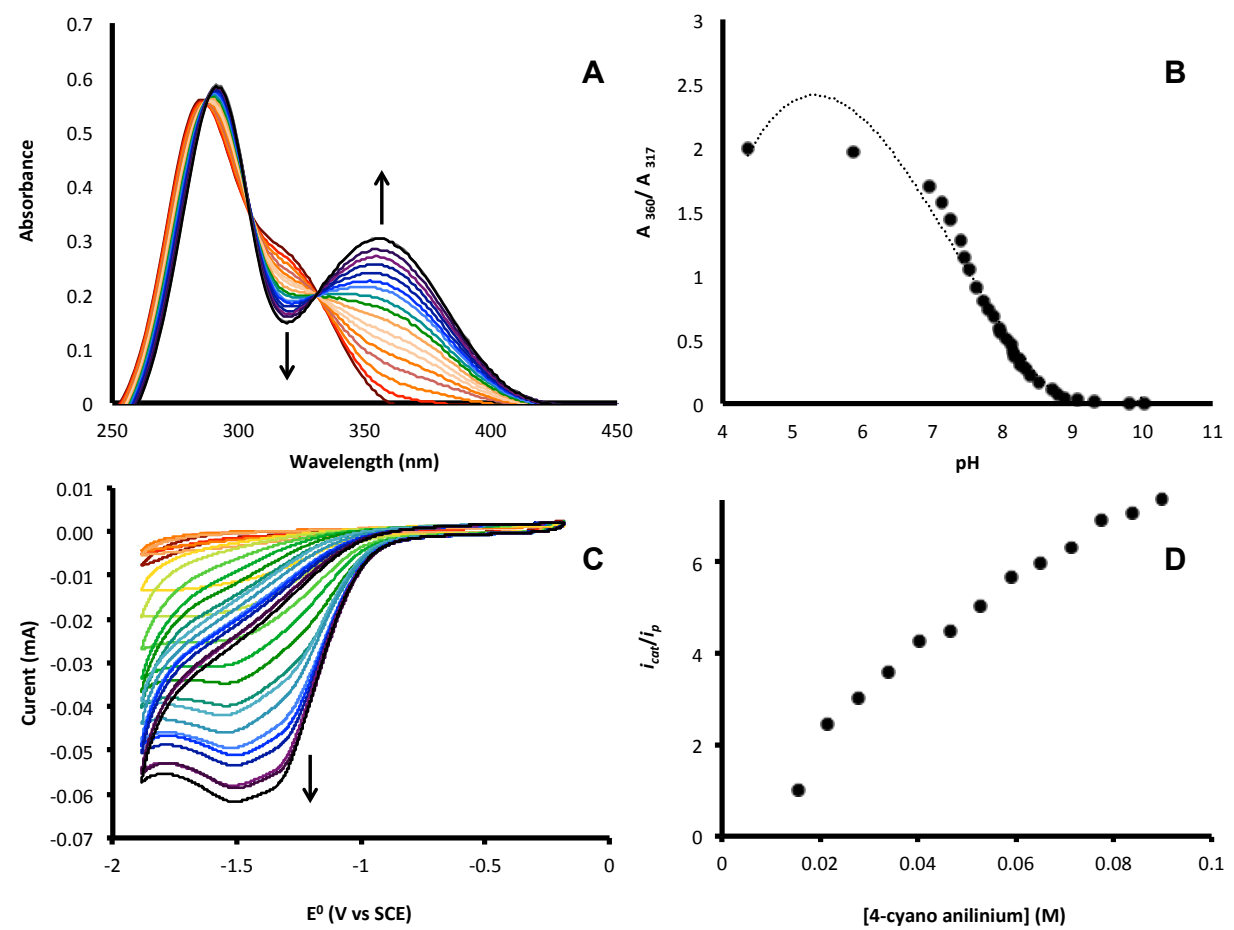

Appendix Figure 3: A) UV-vis absorbance spectra of a $2 \times 10^{-3} \mathrm{M}$ solution of $\mathrm{Ni}(5-$ $\left.\mathrm{CF}_{3} \mathrm{PyS}\right)_{3}{ }^{-}$in $1: 1 \mathrm{H}_{2} \mathrm{O} / \mathrm{EtOH}$ as it is titrated with $0.1 \mathrm{M}$ aqueous $\mathrm{HCl}$ to yield $\mathrm{Ni}(5-$ $\left.\mathrm{CF}_{3} \mathrm{PyS}\right)_{3} \mathrm{H} \mathrm{B}$ ) plot of the ratio of the absorbance at $\lambda_{\max }$ for $\mathrm{Ni}\left(5-\mathrm{CF}_{3} \mathrm{PyS}\right)_{3}{ }^{-} / \mathrm{Ni}(5-$ $\left.\mathrm{CF}_{3} \mathrm{PyS}\right)_{3} \mathrm{H}$ vs $\mathrm{pH} \mathrm{C}$ ) Cyclic voltammograms of a $6.2 \times 10^{-3} \mathrm{M} \mathrm{Ni}\left(5-\mathrm{CF}_{3} \mathrm{PyS}\right)_{3}{ }^{-}$in dry/degassed acetonitrile taken at a scan rate of $500 \mathrm{mV} / \mathrm{s}$ starting at $0 \mathrm{~V}$ vs $\mathrm{Ag}^{+} / \mathrm{AgNO}_{3}$ and D) plot of $i_{\text {cat }} / i_{\mathrm{p}}$ vs [4-cyanoanilinium] 

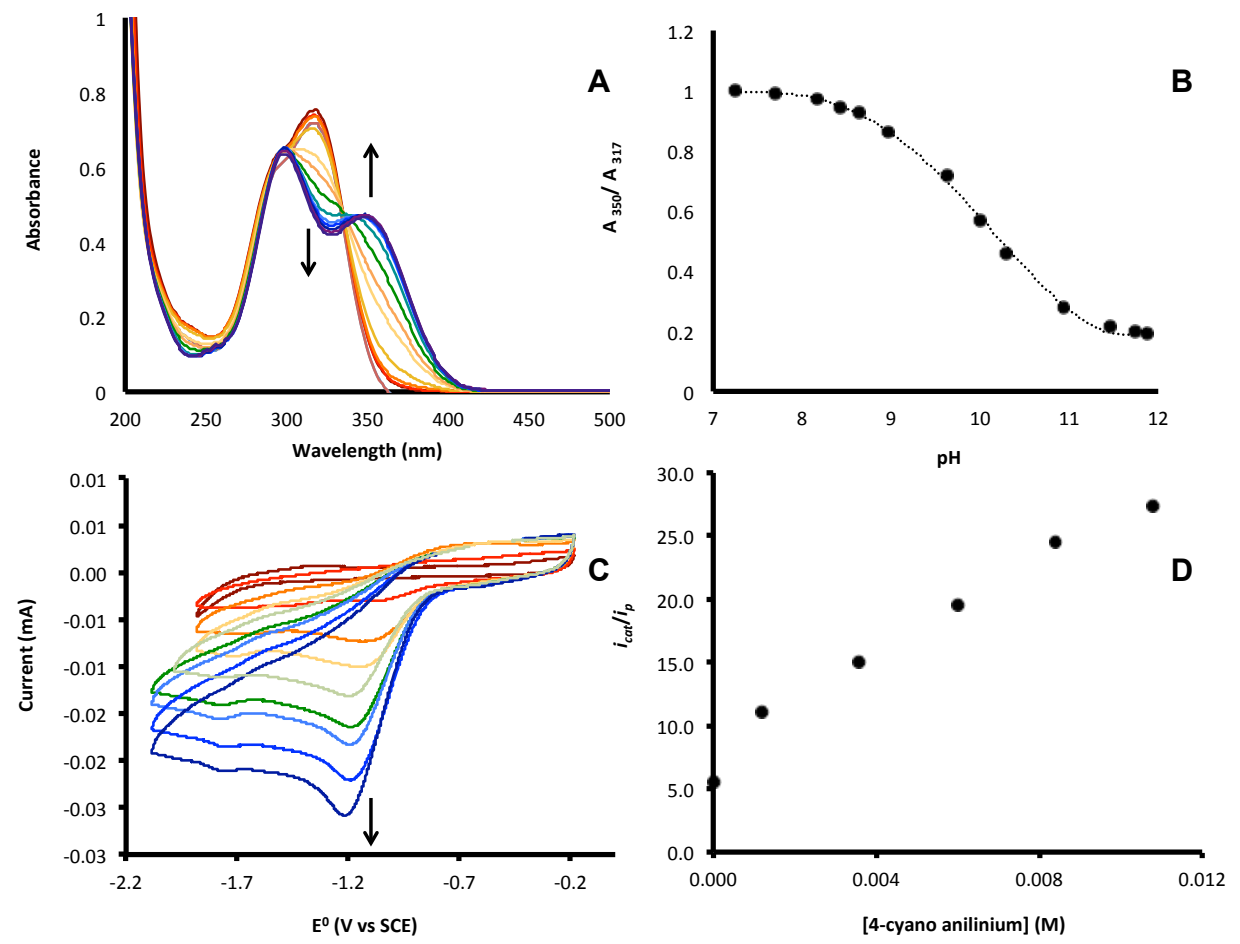

Appendix Figure 4: A) UV-vis absorbance spectra of a $1.1 \times 10^{-4} \mathrm{M}$ solution of Ni(6-S-3COOHPyS $)_{3}{ }^{-}$in $1: 1 \mathrm{H}_{2} \mathrm{O} / \mathrm{EtOH}$ as it is titrated with $0.1 \mathrm{M}$ aqueous $\mathrm{HCl}$ to yield $\mathrm{Ni}(6-\mathrm{S}-3-$ $\mathrm{COOHPyS})_{3} \mathrm{H} \mathrm{B}$ ) plot of the ratio of the absorbance at $\lambda_{\max }$ for Ni(6-S-3-COOHPyS $)_{3}{ }^{-}$ $/ \mathrm{Ni}(6-\mathrm{S}-3-\mathrm{COOHPyS})_{3} \mathrm{H}$ vs $\mathrm{pH} \mathrm{C}$ ) Cyclic voltammograms of a $1.2 \times 10^{-3} \mathrm{M} \mathrm{Ni(6-S-3-}$ $\mathrm{COOHPyS})_{3}{ }^{-}$in dry/degassed acetonitrile taken at a scan rate of $500 \mathrm{mV} / \mathrm{s}$ starting at $0 \mathrm{~V}$ vs $\mathrm{Ag}^{+} / \mathrm{AgNO}_{3}$ and D) plot of $i_{\text {cat }} / i_{\mathrm{p}}$ vs [4-cyanoanilinium] 

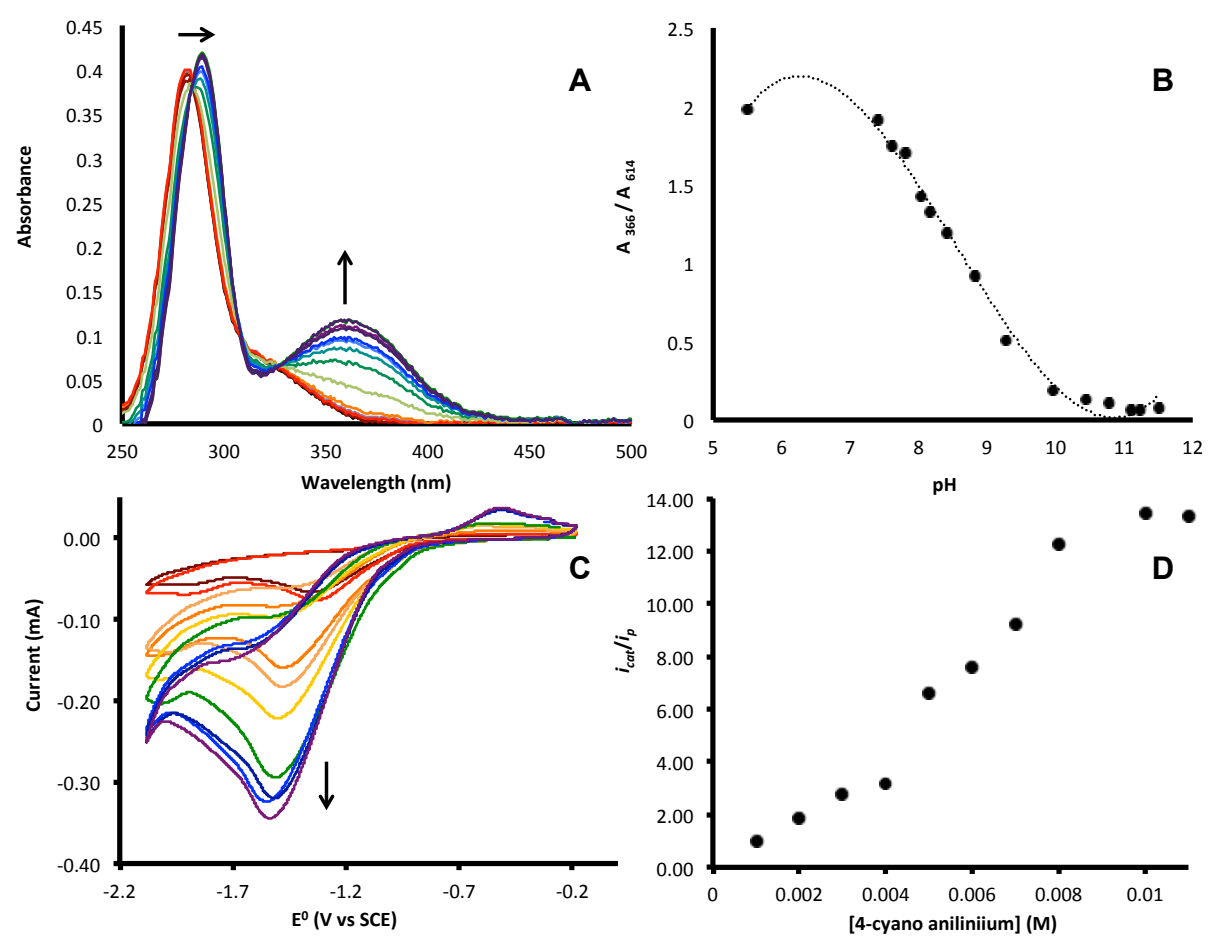

Appendix Figure 5: A) UV-vis absorbance spectra of a $1.2 \times 10^{-4} \mathrm{M}$ solution of Ni(2-S-3COOHPyS $)_{3}{ }^{-}$in $1: 1 \mathrm{H}_{2} \mathrm{O} / \mathrm{EtOH}$ as it is titrated with $0.1 \mathrm{M}$ aqueous $\mathrm{HCl}$ to yield $\mathrm{Ni}(2-\mathrm{S}-$ $3-\mathrm{COOHPyS})_{3} \mathrm{H} \mathrm{B}$ ) plot of the ratio of the absorbance at $\lambda_{\max }$ for Ni(2-S-3-COOHPyS $)_{3}{ }^{-}$ $/ \mathrm{Ni}(2-\mathrm{S}-3-\mathrm{COOHPyS})_{3} \mathrm{H}$ vs $\mathrm{pH} \mathrm{C}$ ) Cyclic voltammograms of a $1.0 \times 10^{-3} \mathrm{M} \mathrm{Ni}(2-\mathrm{S}-3-$ $\mathrm{COOHPyS})_{3}{ }^{-}$in dry/degassed acetonitrile taken at a scan rate of $500 \mathrm{mV} / \mathrm{s}$ starting at $0 \mathrm{~V}$ vs $\mathrm{Ag}^{+} / \mathrm{AgNO}_{3}$ and D) plot of $i_{\text {cat }} / i_{\mathrm{p}}$ vs [4-cyanoanilinium] 

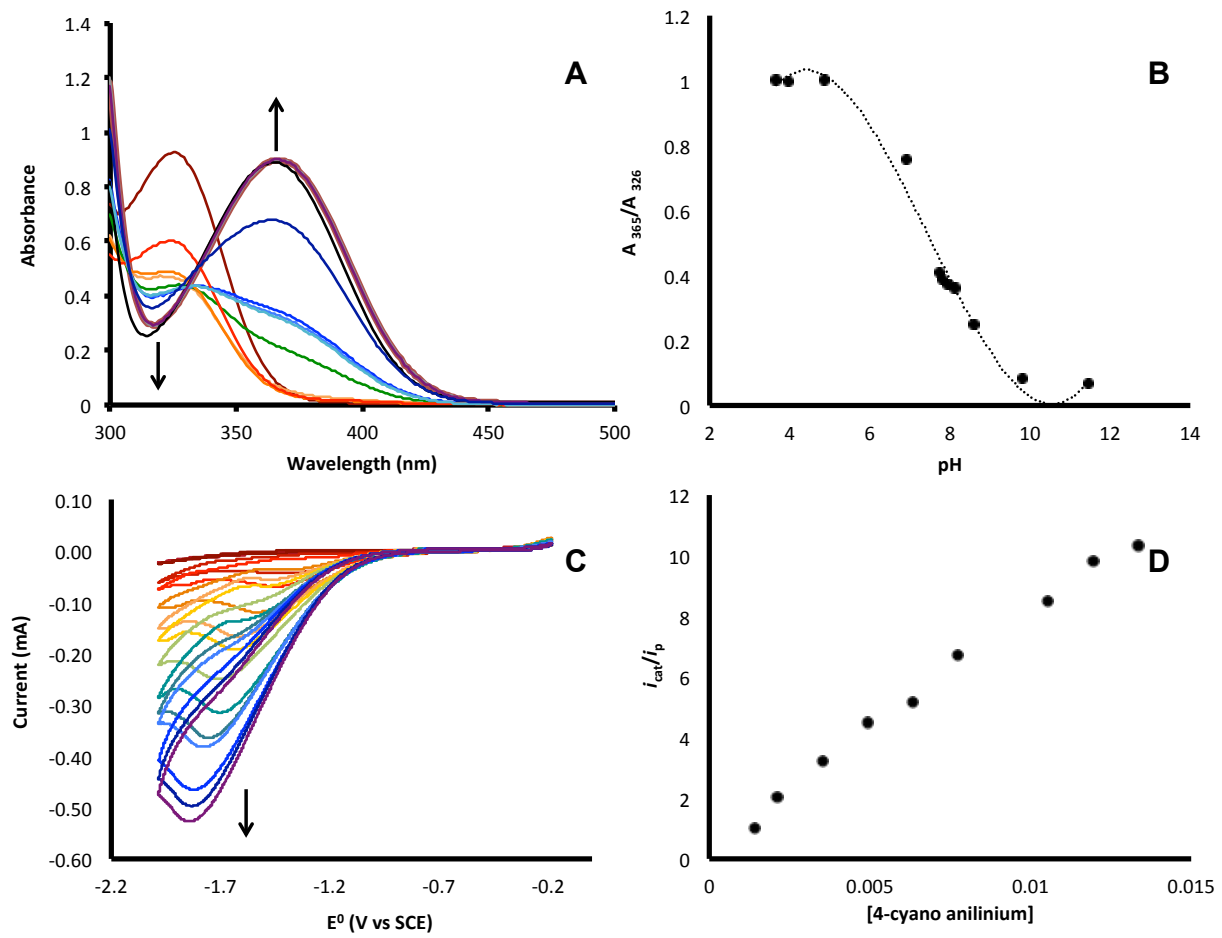

Appendix Figure 6: A) UV-vis absorbance spectra of a $1 \times 10^{-6} \mathrm{M}$ solution of $\mathrm{Ni}(5-$ ClPyS $)_{3}{ }^{-}$in $1: 1 \mathrm{H}_{2} \mathrm{O} / \mathrm{EtOH}$ as it is titrated with $0.1 \mathrm{M}$ aqueous $\mathrm{HCl}$ to yield $\mathrm{Ni}(5-$ $\mathrm{ClPyS})_{3} \mathrm{H} \mathrm{B}$ ) plot of the ratio of the absorbance at $\lambda_{\max }$ for $\mathrm{Ni}(5-\mathrm{ClPyS})_{3}{ }^{-} \mathrm{Ni}(5-\mathrm{ClPyS})_{3} \mathrm{H}$ vs $\mathrm{pH} \mathrm{C}$ ) Cyclic voltammograms of a $0.7 \times 10^{-3} \mathrm{M} \mathrm{Ni}(5-\mathrm{ClPyS})_{3}{ }^{-}$in dry/degassed acetonitrile taken at a scan rate of $500 \mathrm{mV} / \mathrm{s}$ starting at $0 \mathrm{~V} \mathrm{vs} \mathrm{Ag}^{+} / \mathrm{AgNO}_{3}$ and D) plot of $i_{\text {cat }} / i_{\mathrm{p}}$ vs [4-cyanoanilinium] 

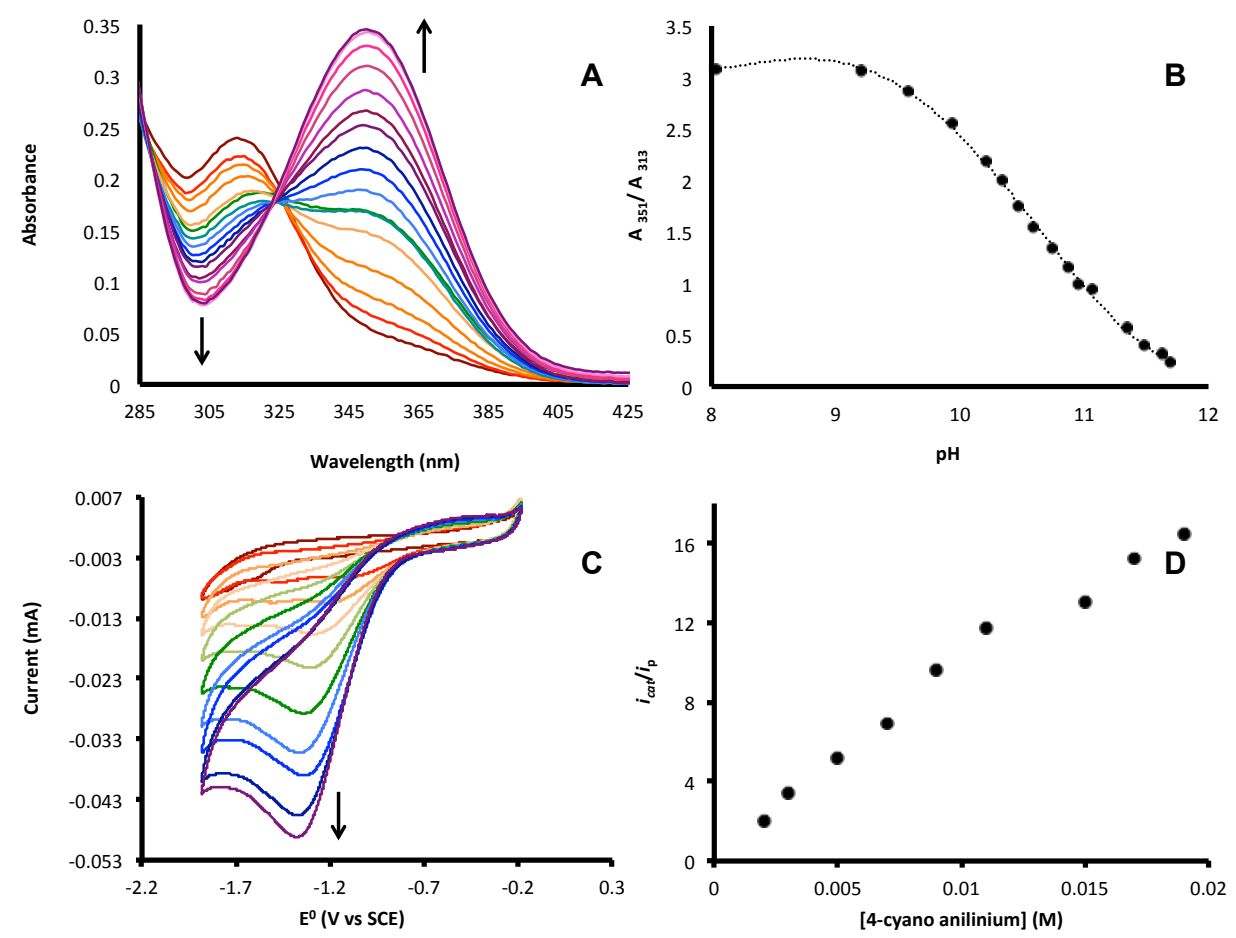

Appendix Figure 7: A) UV-vis absorbance spectra of a $1 \times 10^{-6} \mathrm{M}$ solution of $\mathrm{Ni}(6-$ $\left.\mathrm{CH}_{3} \mathrm{PyS}\right)_{3}{ }^{-}$in $1: 1 \mathrm{H}_{2} \mathrm{O} / \mathrm{EtOH}$ as it is titrated with $0.1 \mathrm{M}$ aqueous $\mathrm{HCl}$ to yield $\mathrm{Ni}(6-$ $\left.\left.\mathrm{CH}_{3} \mathrm{PyS}\right)_{3} \mathrm{H} \mathrm{B}\right)$ plot of the ratio of the absorbance at $\lambda_{\max }$ for $\mathrm{Ni}\left(6-\mathrm{CH}_{3} \mathrm{PyS}\right)_{3}{ }^{-} / \mathrm{Ni}(6-$ $\left.\mathrm{CH}_{3} \mathrm{PyS}\right)_{3} \mathrm{H}$ vs $\mathrm{pH} \mathrm{C}$ ) Cyclic voltammograms of a $1.0 \times 10^{-3} \mathrm{M} \mathrm{Ni}\left(6-\mathrm{CH}_{3} \mathrm{PyS}\right)_{3}{ }^{-}$in dry/degassed acetonitrile taken at a scan rate of $500 \mathrm{mV} / \mathrm{s}$ starting at $0 \mathrm{~V}$ vs $\mathrm{Ag}^{+} / \mathrm{AgNO}_{3}$ and D) plot of $i_{\text {cat }} / i_{\mathrm{p}}$ vs [4-cyanoanilinium]. 


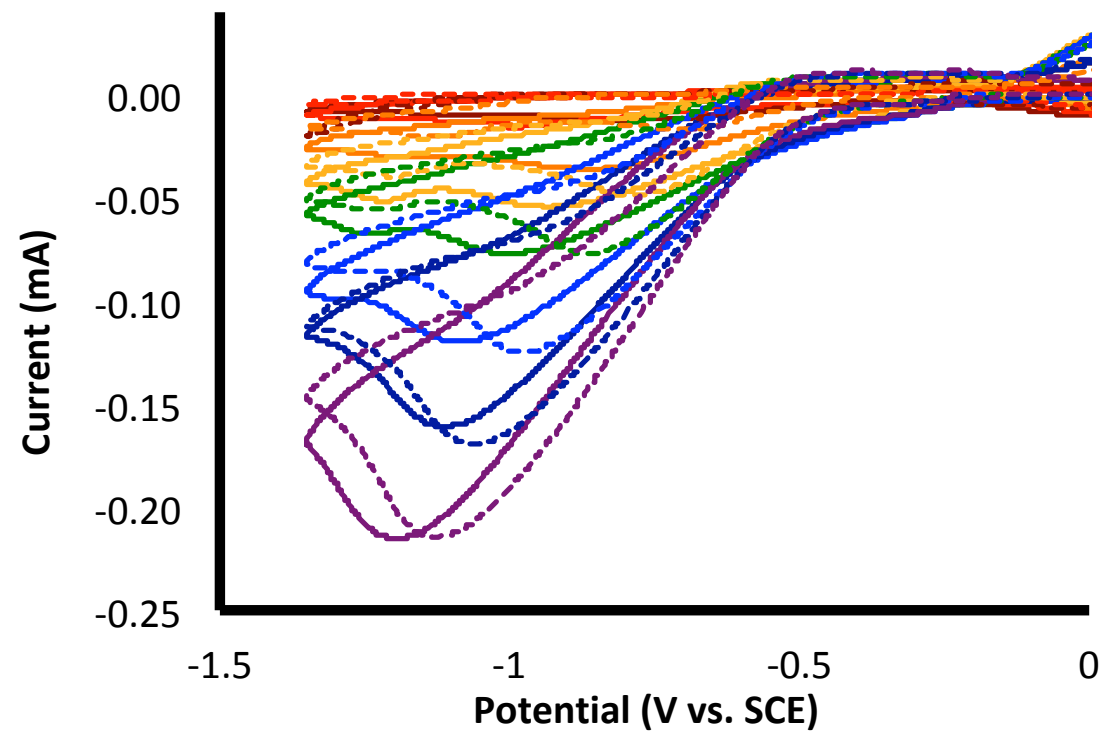

Appendix Figure 8: Cyclic voltammograms of $\mathrm{Ni}\left(6-\mathrm{CH}_{3} \mathrm{PyS}\right)_{3}{ }^{-}$in $1: 1 \mathrm{H}_{2} \mathrm{O} / \mathrm{EtOH}$, using $\mathrm{LiCl}$ and ferrocene, with a glassy carbon working electrode, platinum coil counter electrode and silver wire pseudo reference electrode. Increasing additions of $\mathrm{HCl}$ (dotted) and $\mathrm{DCl}$ (solid) were made and resulted in a thermodynamic shift of $\mathrm{E}^{0}$ (starting with $1,2,3$ equivalents and subsequently increasing to 2 equivalent jumps) thus showing both catalytic wave and kinetic isotope effects. 

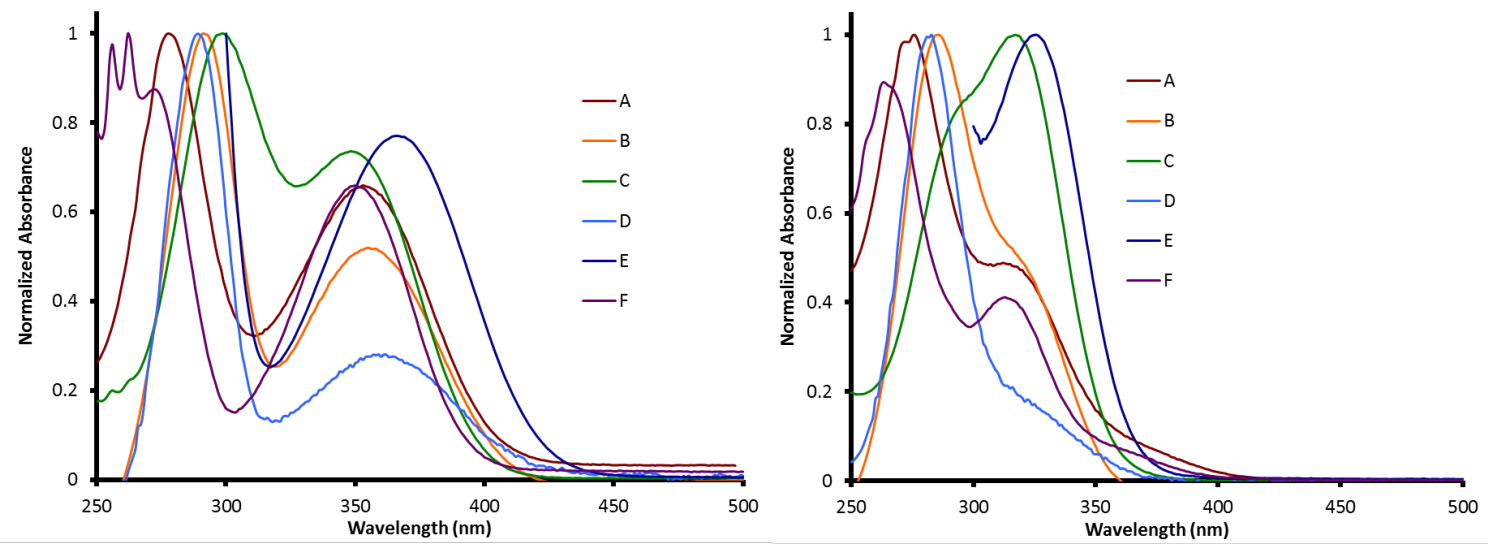

Appendix Figure 9: Normalized UV-vis absorbance spectra for compounds A) $\mathrm{Ni}(3-$ $\left.\left.\left.\left.\left.\mathrm{CF}_{3} \mathrm{PyS}\right)_{3}{ }^{-} \mathrm{B}\right) \mathrm{Ni}\left(5-\mathrm{CF}_{3} \mathrm{PyS}\right)_{3}{ }^{-} \mathrm{C}\right) \mathrm{Ni}(6-\mathrm{S}-3-\mathrm{COOHPyS})_{3}{ }^{-} \mathrm{D}\right) \mathrm{Ni}(2-\mathrm{S}-3-\mathrm{COOHPyS})_{3}{ }^{--} \mathrm{E}\right)$ $\mathrm{Ni}(5-\mathrm{ClPyS})_{3}{ }^{-}$and $\left.\mathrm{F}\right) \mathrm{Ni}\left(6-\mathrm{CH}_{3} \mathrm{PyS}\right)_{3}{ }^{-}$in $1: 1 \mathrm{H}_{2} \mathrm{O} / \mathrm{EtOH}$. Panel A shows the fully protonated spectra obtained by adding excess $1 \mathrm{M}$ aqueous $\mathrm{HCl}$ and panel $\mathrm{B}$ shows the fully deprotonated spectra obtained by adding excess $1 \mathrm{M}$ aqueous $\mathrm{NaOH}$. 

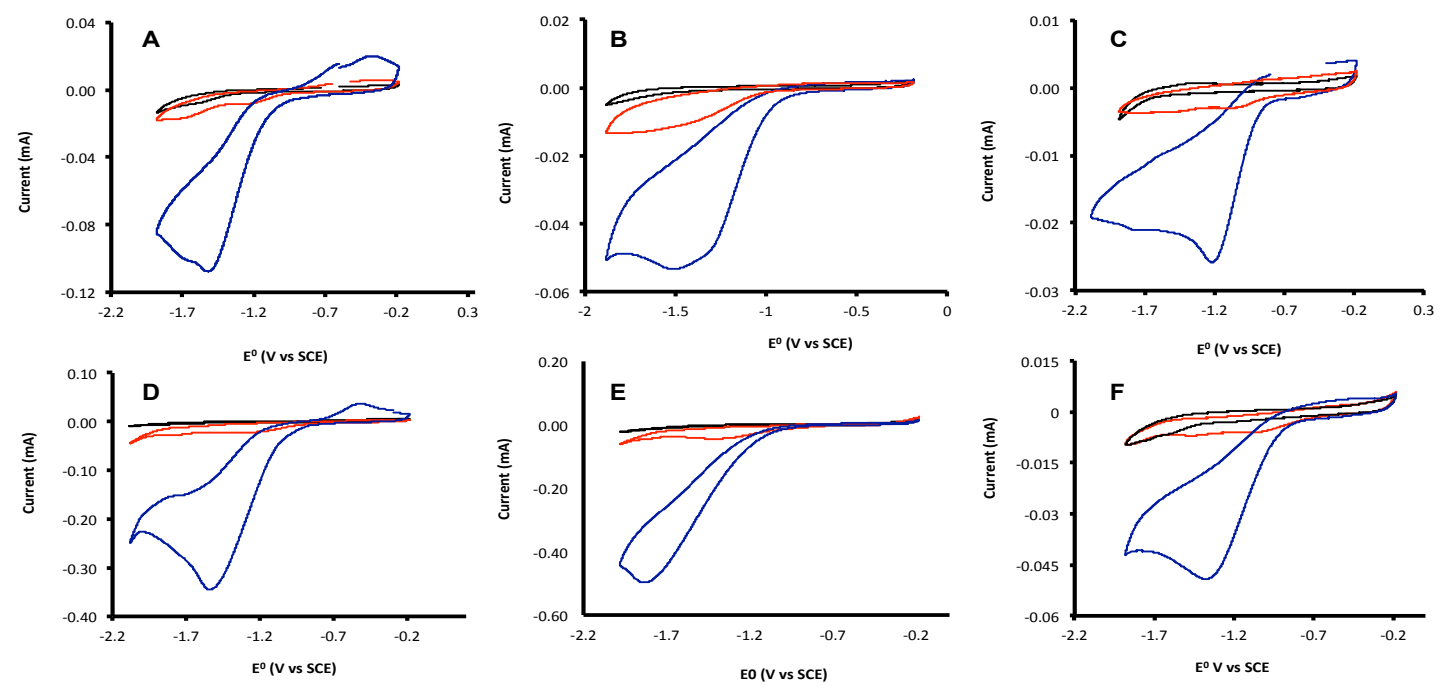

Appendix Figure 10: Cyclic voltammograms of a solution of catalyst in dry/degassed acetonitrile with TBAF A) $\left.\left.\mathrm{Ni}\left(3-\mathrm{CF}_{3} \mathrm{PyS}\right)_{3}{ }^{-} \mathrm{B}\right) \mathrm{Ni}\left(5-\mathrm{CF}_{3} \mathrm{PyS}\right)_{3}{ }^{-} \mathrm{C}\right) \mathrm{Ni}(6-\mathrm{S}-3-\mathrm{COOHPyS})_{3}{ }^{-}$ D) $\left.\mathrm{Ni}(2-\mathrm{S}-3-\mathrm{COOHPyS})_{3}{ }^{-} \mathrm{E}\right) \mathrm{Ni}(5-\mathrm{ClPyS})_{3}{ }^{-}$and $\left.\mathrm{F}\right) \mathrm{Ni}\left(6-\mathrm{CH}_{3} \mathrm{PyS}\right)_{3}{ }^{-}$without 4cyanoanilinium (black), with 1 equivalent of 4-cyanoanilinium (red) and with excess 4cyanoanolinium (blue) at the following equivalents of acid relative to the complex: A) 41, B) 25, C) 15, D) 12 , E) 23, F) 19. 


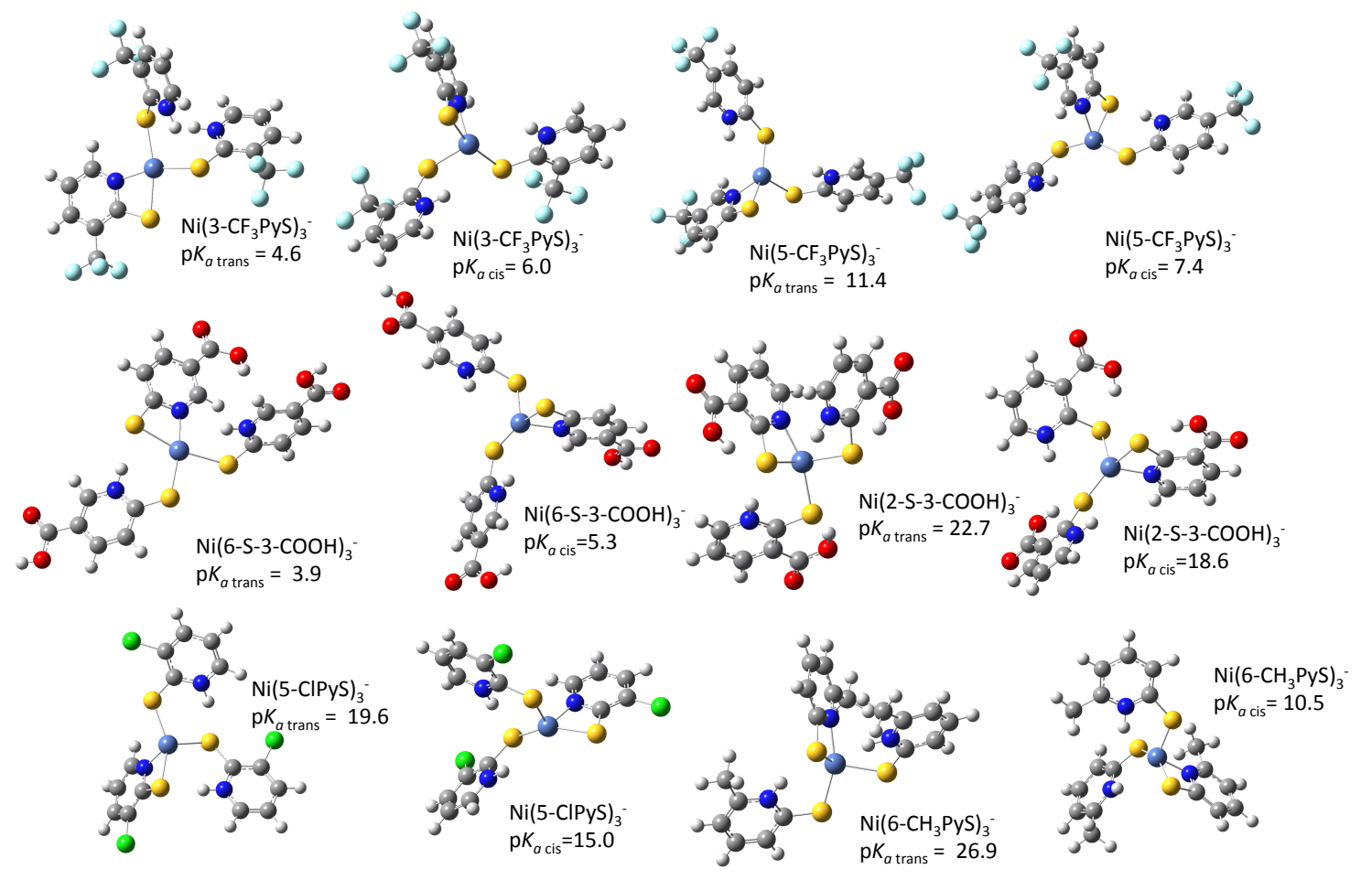

Appendix Figure 11: Optimized structures of the twice protonated intermediate in a CCEE mechanism with corresponding calculated $\mathrm{p} K_{a}$ values for protonation at the nitrogen atom positioned either cis or trans to the originally protonated nitrogen. 
Appendix Table 1: Computed $\mathrm{p} K_{a}$ values for the second protonation event in a CECE mechanism.

\begin{tabular}{|c|c|c|c|c|c|c|c|c|c|}
\hline Second Protonation & & & & & & & & & \\
\hline Compound & L/C pKa & L/R pKa & C/L pKa & C/R pKa & R/L pKa & $\mathrm{R} / \mathrm{C}$ pKa & L/M & $\mathrm{C} / \mathrm{M}$ & $\mathrm{R} / \mathrm{M}$ \\
\hline $\mathrm{Ni}\left(3-\mathrm{CF}_{3} \mathrm{PyS}\right)_{2}(\mathrm{PyS})^{-[\mathrm{L}]}$ & 11.51 & 9.65 & - & - & - & - & 0.95 & - & - \\
\hline $\mathrm{Ni}\left(3-\mathrm{CF}_{3} \mathrm{PyS}\right)_{2}(\mathrm{PyS})^{-}[\mathrm{C}]$ & 12.82 & 10.46 & 11.51 & 11.33 & 11.60 & 14.30 & -0.83 & -1.46 & 1.13 \\
\hline $\mathrm{Ni}\left(3-\mathrm{CF}_{3} \mathrm{PyS}\right)_{2}(\mathrm{PyS})^{-}[\mathrm{R}]$ & - & - & - & - & 9.77 & 12.11 & - & - & 1.40 \\
\hline $\mathrm{Ni}(\mathrm{PyS})_{2}\left(3-\mathrm{CF}_{3} \mathrm{PyS}\right)^{-[L]}$ & 13.24 & 13.83 & - & - & 9.99 & 14.65 & 1.02 & - & 3.55 \\
\hline $\mathrm{Ni}(\mathrm{PyS})_{2}\left(3-\mathrm{CF}_{3} \mathrm{PyS}\right)^{-}[\mathrm{C}]$ & 11.67 & 13.50 & - & - & 14.80 & 12.37 & 4.19 & - & - \\
\hline $\mathrm{Ni}(\mathrm{PyS})_{2}\left(3-\mathrm{CF}_{3} \mathrm{PyS}\right)^{-[R]}$ & 13.76 & 11.68 & - & - & 13.06 & 14.53 & 4.19 & - & - \\
\hline $\mathrm{Ni}(\mathrm{PyS})_{2}\left(6-\mathrm{CH}_{3} \mathrm{PyS}\right)^{-[\mathrm{L}]}$ & 14.43 & - & 16.56 & 14.21 & - & - & 1.39 & 2.20 & - \\
\hline $\begin{array}{c}\mathrm{Ni}(\mathrm{PyS})_{2}\left(6-\mathrm{CH}_{3} \mathrm{PyS}\right)^{-} \\
{[\mathrm{C}]}\end{array}$ & - & 13.83 & 15.84 & 13.53 & 11.73 & 14.45 & 6.77 & 1.38 & 1.10 \\
\hline $\begin{array}{c}\mathrm{Ni}(\mathrm{PyS})_{2}\left(6-\mathrm{CH}_{3} \mathrm{PyS}\right)^{-} \\
{[\mathrm{R}]}\end{array}$ & 14.53 & 16.55 & 14.59 & 15.19 & 14.56 & 14.16 & (S) 8.32 & (S) 9.25 & 1.53 \\
\hline $\mathrm{Ni}\left(6-\mathrm{CH}_{3} \mathrm{PyS}\right)_{2}(\mathrm{PyS})^{-[\mathrm{L}]}$ & - & - & 15.87 & 16.53 & - & - & - & 3.61 & - \\
\hline $\mathrm{Ni}\left(6-\mathrm{CH}_{3} \mathrm{PyS}\right)_{2}(\mathrm{PyS})^{-}[\mathrm{C}]$ & 15.85 & 16.58 & 16.87 & 18.64 & 17.66 & 16.24 & 3.65 & - & 3.91 \\
\hline $\begin{array}{c}\mathrm{Ni}\left(6-\mathrm{CH}_{3} \mathrm{PyS}\right)_{2}(\mathrm{PyS})^{-} \\
{[\mathrm{R}]}\end{array}$ & 16.52 & 15.80 & 16.82 & 14.85 & - & - & 3.60 & (S) 10.09 & - \\
\hline
\end{tabular}


Appendix Table 2: Computed values for $\mathrm{E}^{0}$ for the second reduction event in a CECE mechanism.

\begin{tabular}{|c|c|c|c|c|c|c|c|c|c|}
\hline Compound & L/C EO & L/R EO & C/LEO & C/R EO & R/L EO & R/C EO & L/M EO & C/M EO & R/M EO \\
\hline $\mathrm{Ni}\left(3-\mathrm{CF}_{3} \mathrm{PyS}\right)_{2}(\mathrm{PyS})^{-}[\mathrm{L}]$ & -2.04 & -1.56 & - & - & - & - & -1.13 & - & - \\
\hline $\mathrm{Ni}\left(3-\mathrm{CF}_{3} \mathrm{PyS}\right)_{2}(\mathrm{PyS})^{-}[\mathrm{C}]$ & -2.04 & -1.98 & -2.04 & -2.00 & -2.04 & - & -1.10 & -0.82 & -1.13 \\
\hline $\mathrm{Ni}\left(3-\mathrm{CF}_{3} \mathrm{PyS}\right)_{2}(\mathrm{PyS})^{-}[\mathrm{R}]$ & - & - & - & - & -1.92 & -2.03 & - & - & -1.15 \\
\hline $\mathrm{Ni}(\mathrm{PyS})_{2}\left(3-\mathrm{CF}_{3} \mathrm{PyS}\right)^{-[L]}$ & -1.98 & -2.02 & - & - & -1.88 & -2.34 & -1.17 & - & -1.03 \\
\hline $\mathrm{Ni}(\mathrm{PyS})_{2}\left(3-\mathrm{CF}_{3} \mathrm{PyS}\right)^{-[\mathrm{C}]}$ & -2.01 & -2.27 & - & - & -2.33 & -1.99 & -1.03 & - & - \\
\hline $\mathrm{Ni}(\mathrm{PyS})_{2}\left(3-\mathrm{CF}_{3} \mathrm{PyS}\right)^{-[R]}$ & -2.28 & -2.02 & - & - & -2.04 & -2.06 & -0.96 & - & - \\
\hline $\mathrm{Ni}(\mathrm{PyS})_{2}\left(6-\mathrm{CH}_{3} \mathrm{PyS}\right)^{-[\mathrm{L}]}$ & -2.40 & - & -2.40 & -2.34 & - & - & -1.08 & -1.28 & - \\
\hline $\mathrm{Ni}(\mathrm{PyS})_{2}\left(6-\mathrm{CH}_{3} \mathrm{PyS}\right)^{-}[\mathrm{C}]$ & - & - & -1.95 & -1.85 & -2.29 & -2.36 & -1.04 & -1.09 & -1.13 \\
\hline $\mathrm{Ni}(\mathrm{PyS})_{2}\left(6-\mathrm{CH}_{3} \mathrm{PyS}\right)^{-[\mathrm{R}]}$ & -2.36 & -2.39 & - & -2.39 & -2.43 & -2.33 & - & - & -1.25 \\
\hline $\mathrm{Ni}\left(6-\mathrm{CH}_{3} \mathrm{PyS}\right)_{2}(\mathrm{PyS})^{-[L]}$ & - & - & -2.31 & -1.92 & - & - & - & -1.23 & - \\
\hline $\mathrm{Ni}\left(6-\mathrm{CH}_{3} \mathrm{PyS}\right)_{2}(\mathrm{PyS})^{-}[\mathrm{C}]$ & -1.87 & -2.80 & -2.31 & -1.93 & -2.77 & -1.93 & -1.23 & -1.44 & -1.19 \\
\hline $\mathrm{Ni}\left(6-\mathrm{CH}_{3} \mathrm{PyS}\right)_{2}(\mathrm{PyS})^{-}[\mathrm{R}]$ & -1.97 & -1.98 & -1.97 & -2.32 & - & - & -1.23 & -1.59 & - \\
\hline
\end{tabular}




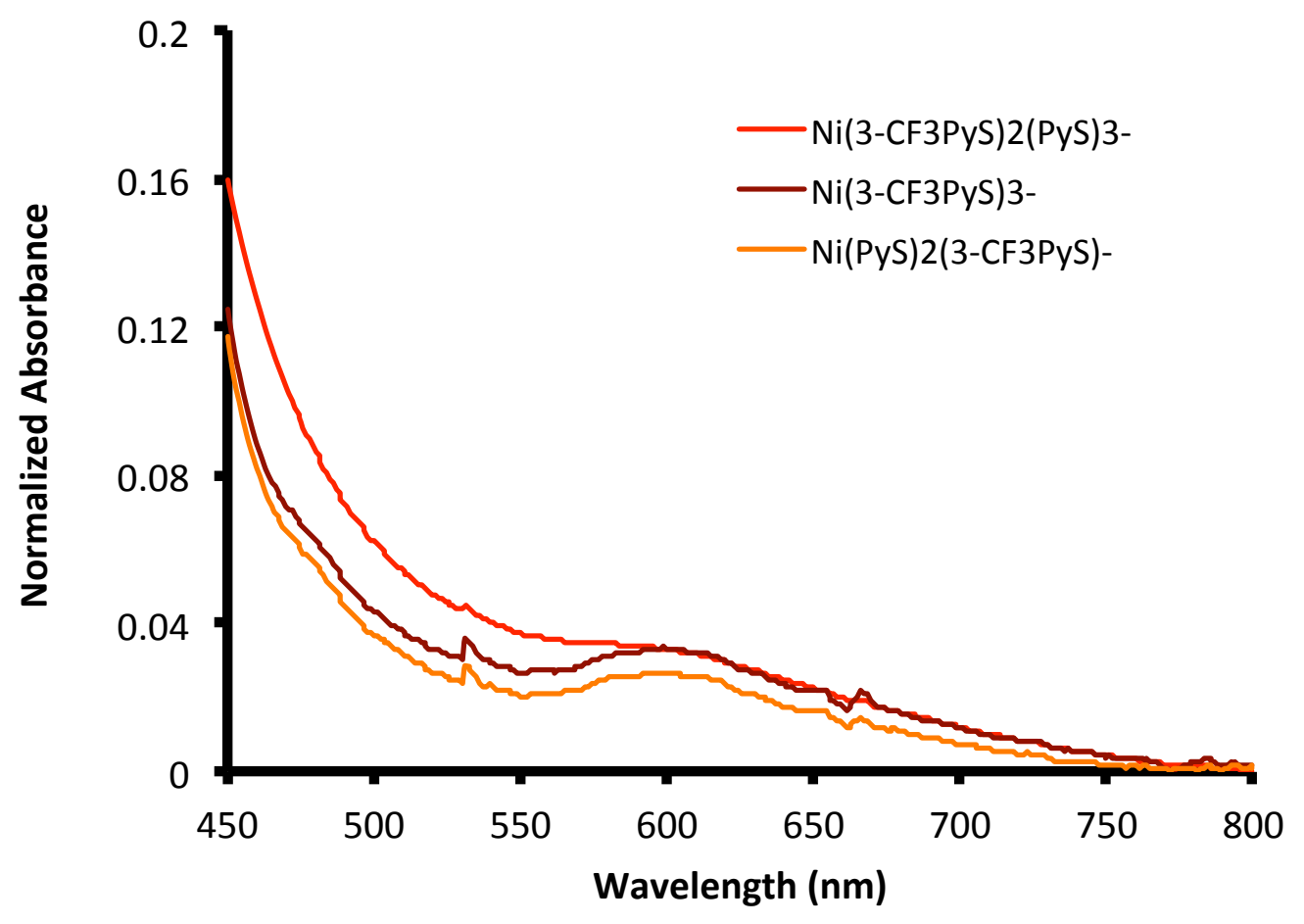

Appendix Figure 12: Absorbance spectra for solutions of $\mathrm{Ni}\left(3-\mathrm{CF}_{3} \mathrm{PyS}\right)_{3}{ }^{-}$, $\mathrm{Ni}(3-$ $\left.\mathrm{CF}_{3} \mathrm{PyS}\right)_{2}(\mathrm{PyS})^{-}$and $\mathrm{Ni}(\mathrm{PyS})_{2}\left(3-\mathrm{CF}_{3} \mathrm{PyS}\right)^{-}$in $1: 1 \mathrm{H}_{2} \mathrm{O} / \mathrm{EtOH}$. 

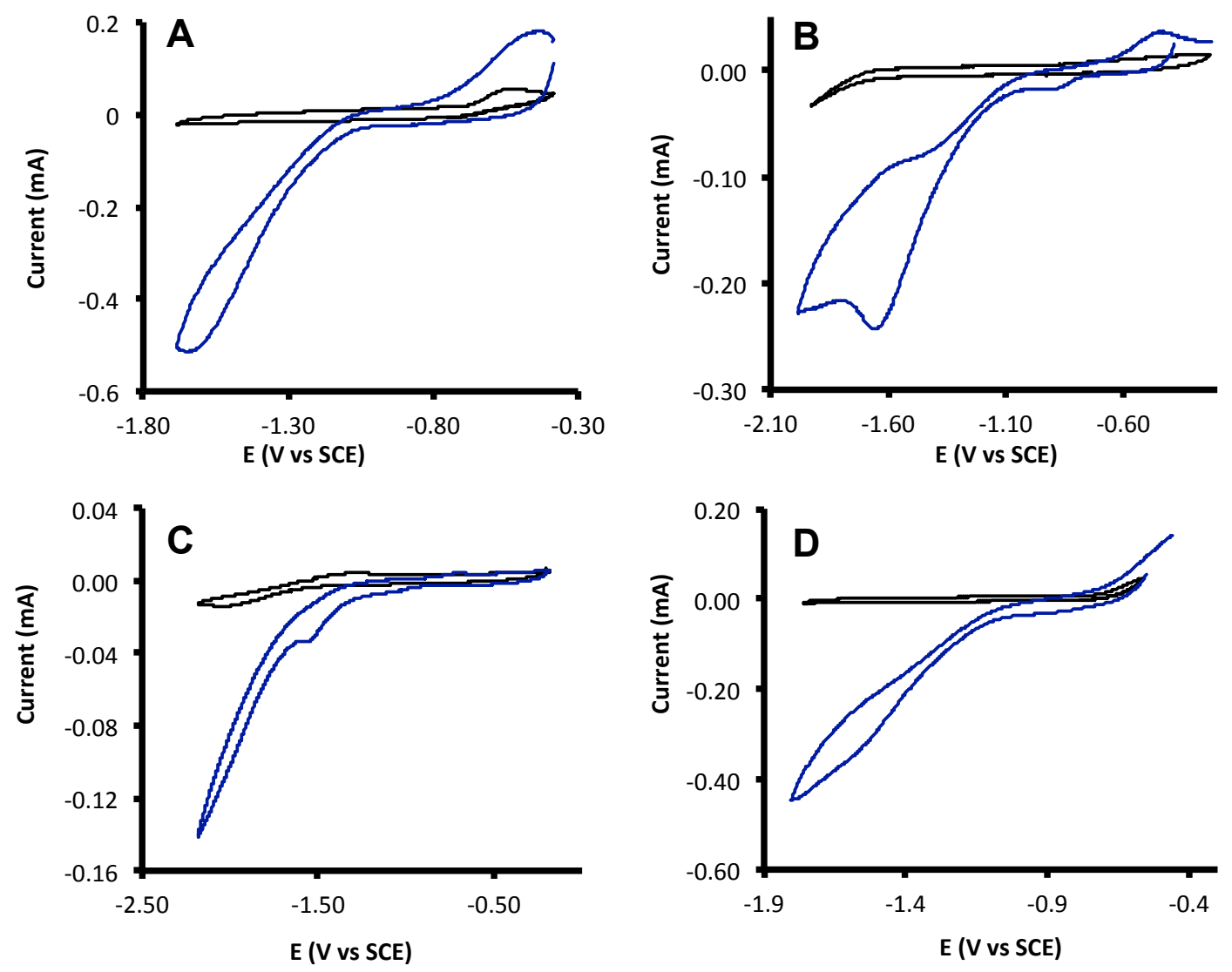

Appendix Figure 13: Cyclic voltammetry traces in the absence of acid (black trace) and in the presence of 4-cyanoanilinium (blue trace) for $\left.\mathrm{A}) \mathrm{Ni}\left(3-\mathrm{CF}_{3} \mathrm{PyS}\right)_{2}(\mathrm{PyS})^{-} \mathrm{B}\right)$ $\left.\mathrm{Ni}(\mathrm{PyS})_{2}\left(3-\mathrm{CF}_{3} \mathrm{PyS}\right)^{-} \mathrm{C}\right) \mathrm{Ni}(\mathrm{PyS})_{2}\left(6-\mathrm{CH}_{3} \mathrm{PyS}\right)^{-}$and D) $\mathrm{Ni}\left(6-\mathrm{CH}_{3} \mathrm{PyS}\right)_{2}(\mathrm{PyS})^{-}$. 

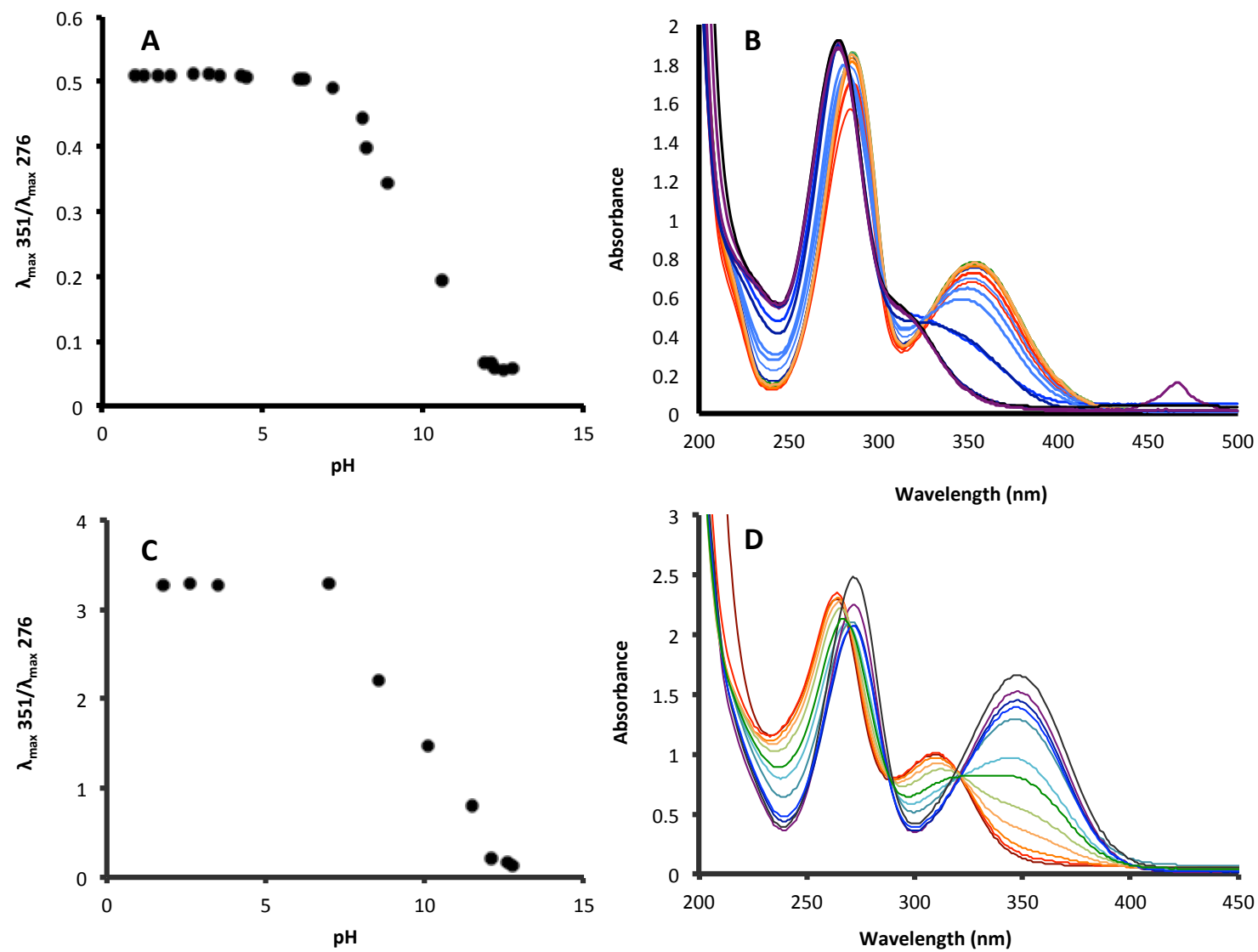

Appendix Figure 14: $\mathrm{Ni}\left(3-\mathrm{CF}_{3} \mathrm{PyS}\right)_{2}(\mathrm{PyS})^{-}$series A) and $\left.\mathrm{C}\right)$ absorbance ratio of protonated and deprotonated catalyst as a function of $\mathrm{pH}$ where inflection point is used to determine $\mathrm{p} K_{a} \mathrm{~B}$ ) and D) UV-vis absorbance spectra. 

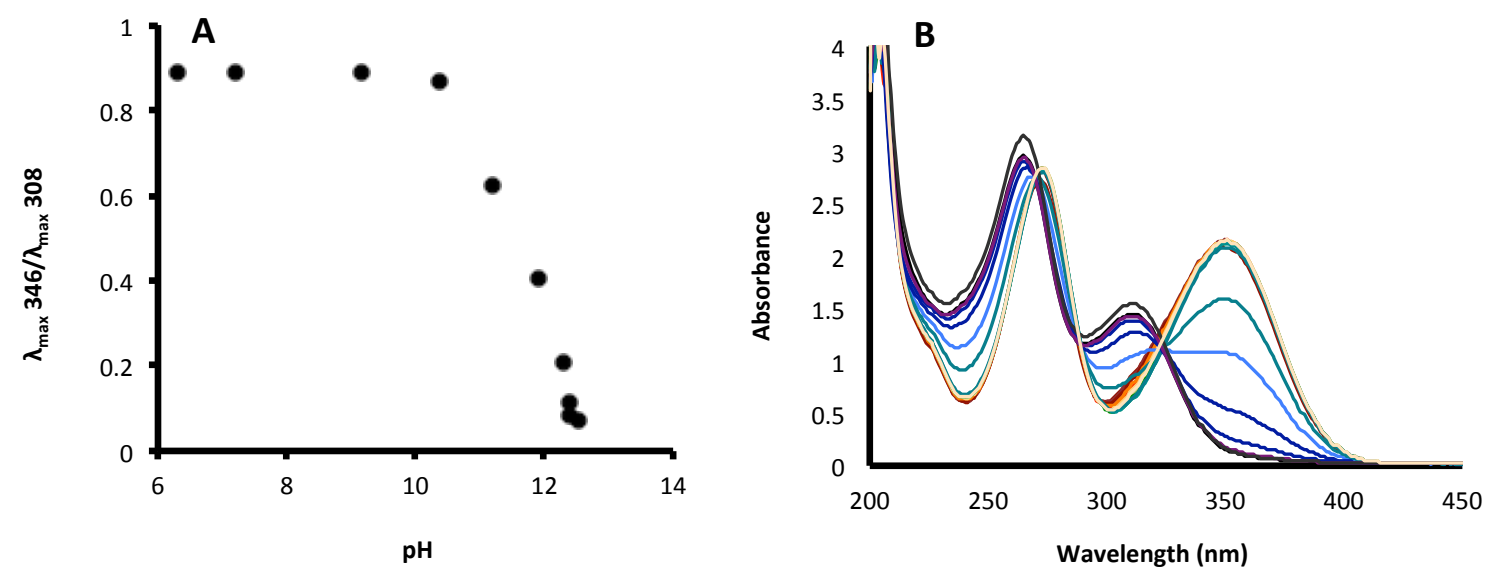

Appendix Figure 15: $\mathrm{Ni}\left(6-\mathrm{CH}_{3} \mathrm{PyS}\right)_{2}(\mathrm{PyS})^{-}$data $\left.\mathrm{A}\right)$ absorbance ratio of protonated and deprotonated catalyst as a function of $\mathrm{pH}$ where inflection point is used to determine $\left.\mathrm{p} K_{a} \mathrm{~B}\right) \mathrm{UV}$-vis absorbance spectra. 

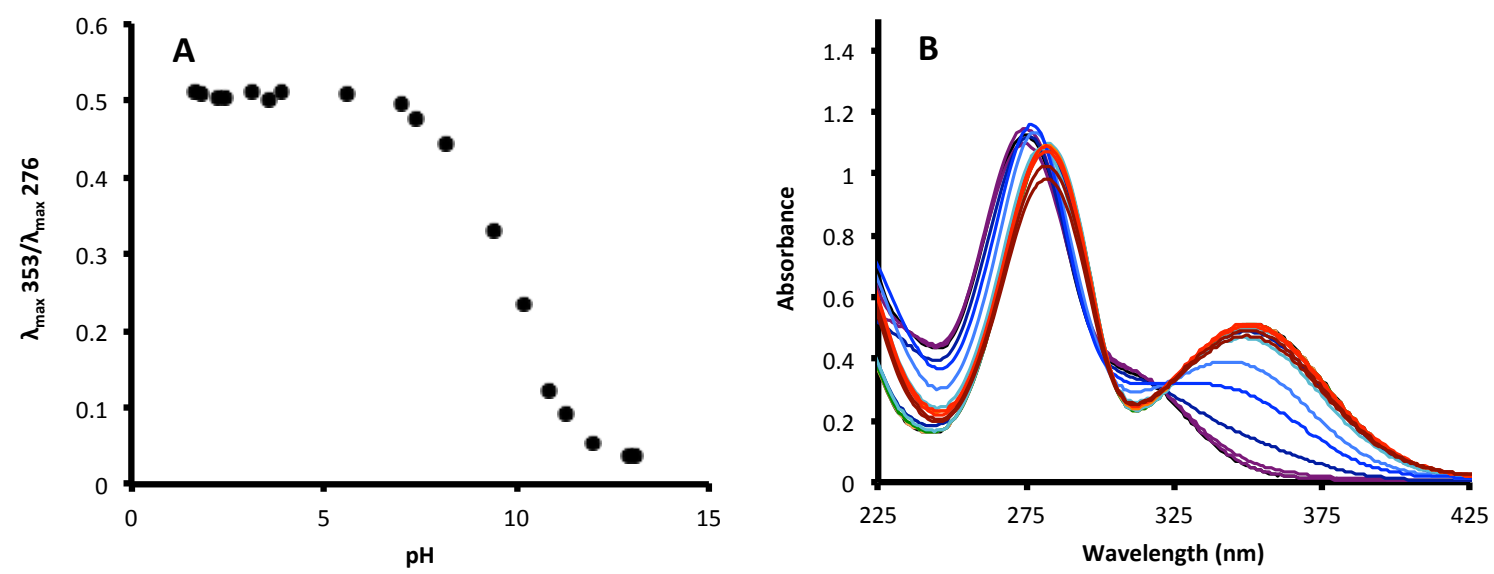

Appendix Figure 16: $\mathrm{Ni}(\mathrm{PyS})_{2}\left(3-\mathrm{CF}_{3} \mathrm{PyS}\right)^{-}$data for $\left.\mathrm{A}\right)$ absorbance ratio of protonated and deprotonated catalyst as a function of $\mathrm{pH}$ where inflection point is used to determine $\left.\mathrm{p} K_{a} \mathrm{~B}\right) \mathrm{UV}$-vis absorbance spectra. 

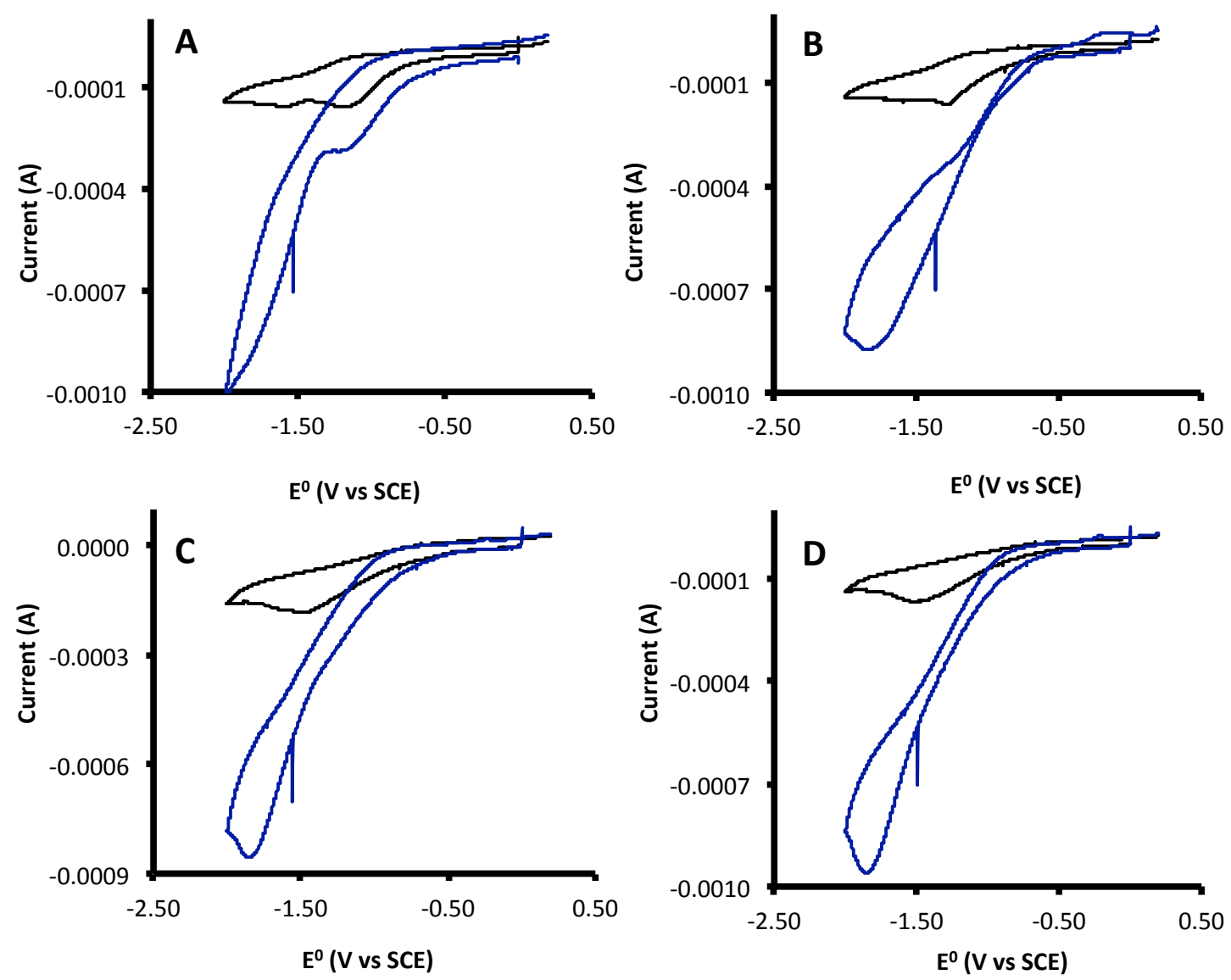

Appendix Figure 17: Cyclic voltammetry traces with $10^{-3} \mathrm{M}$ 4-cyanoanilinium (black trace) and with $2.2 \times 10^{-2} \mathrm{M}$ 4-cyanoanilinium (blue trace) for A) $\mathrm{Ni}\left(3-\mathrm{CF}_{3} \mathrm{PyS}\right)_{2}(\mathrm{PyS})^{-}$ B) $\left.\mathrm{Ni}(\mathrm{PyS})_{2}\left(3-\mathrm{CF}_{3} \mathrm{PyS}\right)^{-} \mathrm{C}\right) \mathrm{Ni}(\mathrm{PyS})_{2}\left(6-\mathrm{CH}_{3} \mathrm{PyS}\right)^{-}$and D) $\mathrm{Ni}\left(6-\mathrm{CH}_{3} \mathrm{PyS}\right)_{2}(\mathrm{PyS})^{-}$. 

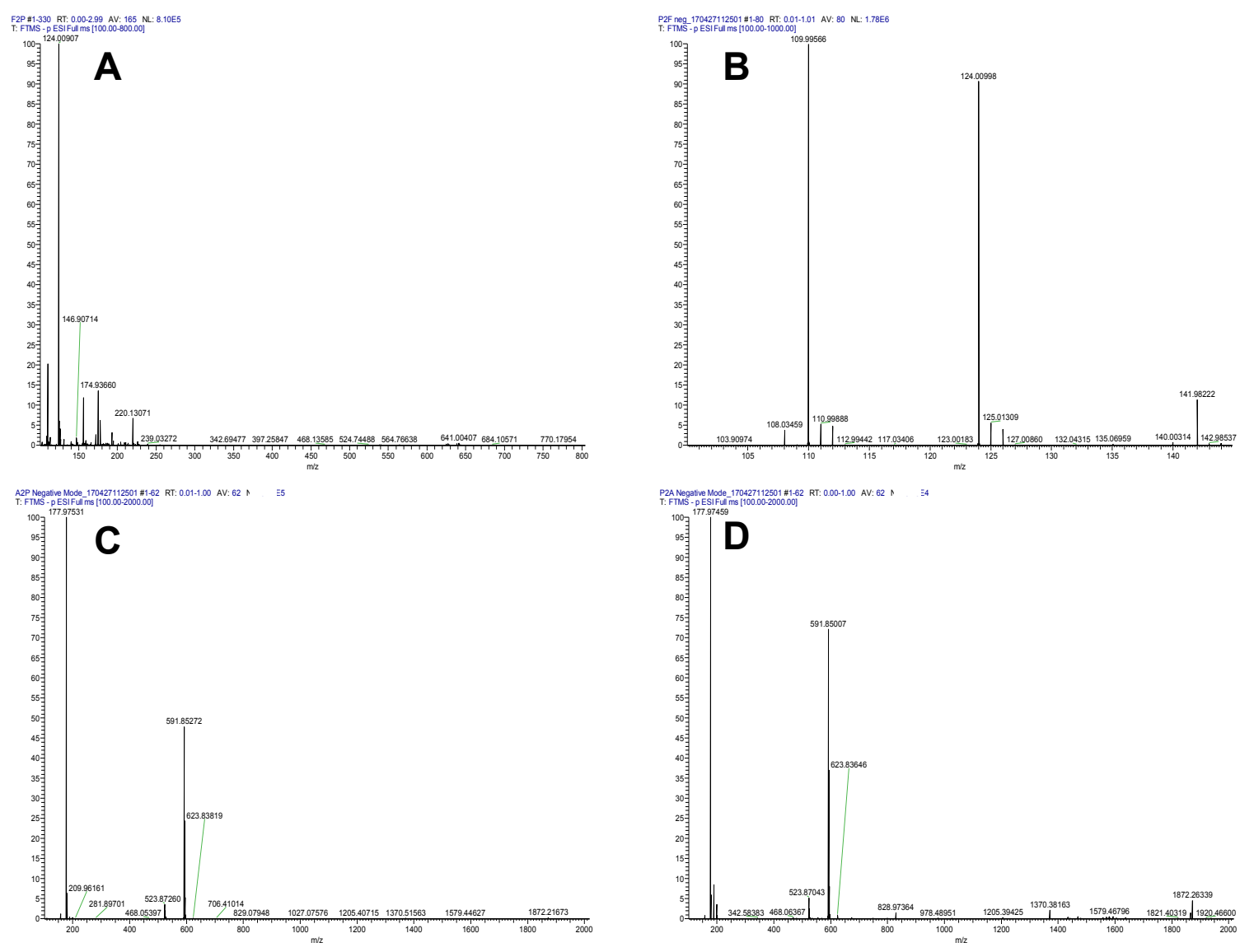

Appendix Figure 18: Mass spectra for A) $\left.\mathrm{Ni}\left(6-\mathrm{CH}_{3} \mathrm{PyS}\right)_{2}(\mathrm{PyS})^{-} \mathrm{B}\right) \mathrm{Ni}(\mathrm{PyS})_{2}(6-$ $\left.\left.\left.\mathrm{CH}_{3} \mathrm{PyS}\right)^{-} \mathrm{C}\right) \mathrm{Ni}(\mathrm{PyS})_{2}\left(3-\mathrm{CF}_{3} \mathrm{PyS}\right)^{-} \mathrm{D}\right) \mathrm{Ni}\left(3-\mathrm{CF}_{3} \mathrm{PyS}\right)_{2}(\mathrm{PyS})^{-}$. Spectra were recorded on a thermal electron LTQ-Orbitrap Discovery high-resolution mass spectrometer with negative mode ESI. 


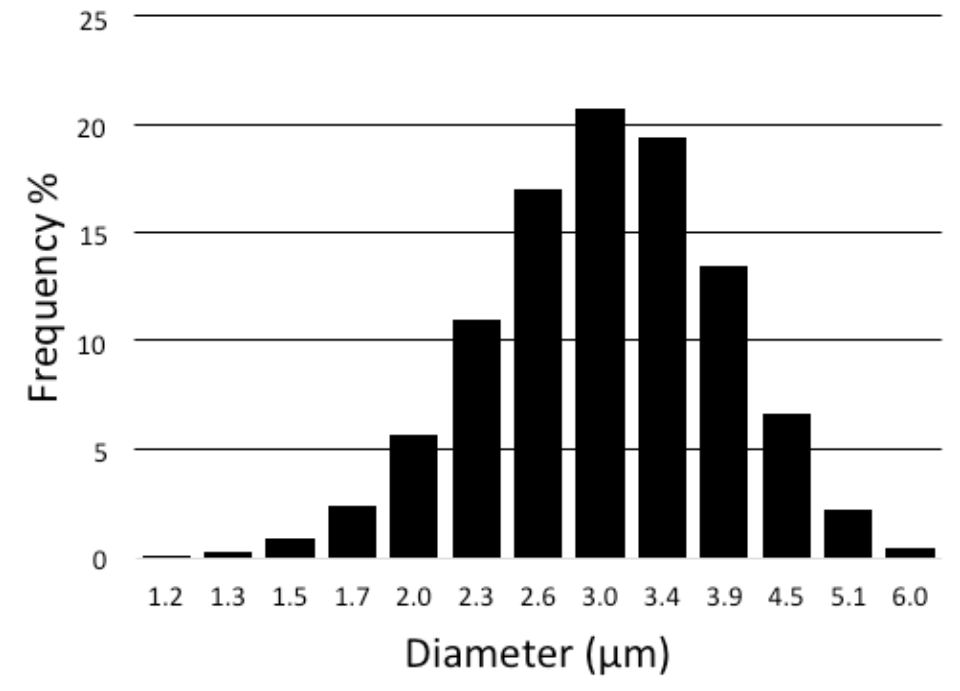

Appendix Figure 19: Size distribution of NiNPs as determined through TEM. 


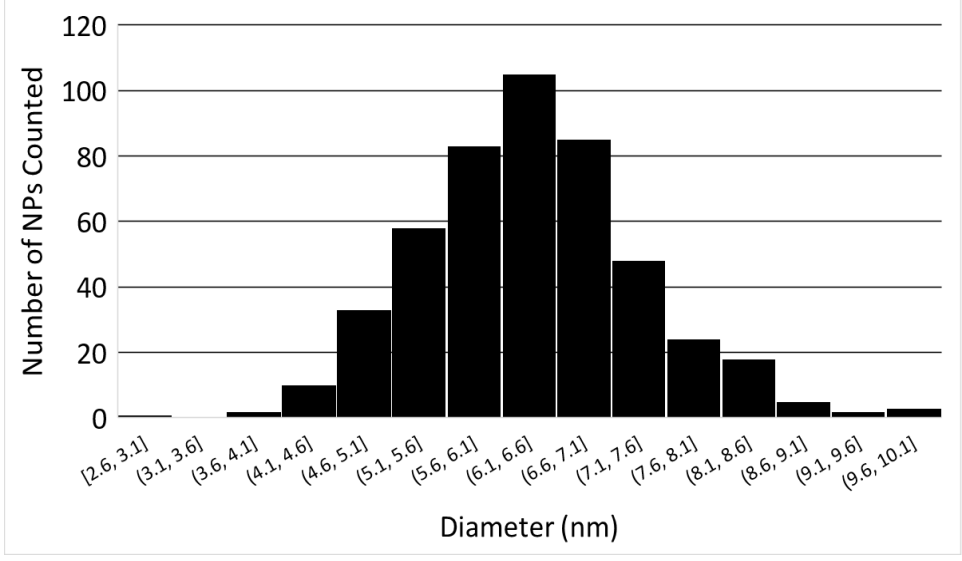

Appendix Figure 20: Dynamic Light Scattering (DLS) data of NiNPs coated with PVP. DLS measurements were performed on a Horiba LB-550 DLS instrument. A concentrated $100 \mu \mathrm{L}$ sample of Ni NPs was added to $2 \mathrm{~mL}$ of DI water. The dispersion was then sonicated, passed through a $0.2 \mu \mathrm{m}$ PTFE syringe filter, and sonicated in the measurement cuvette before measurement. 


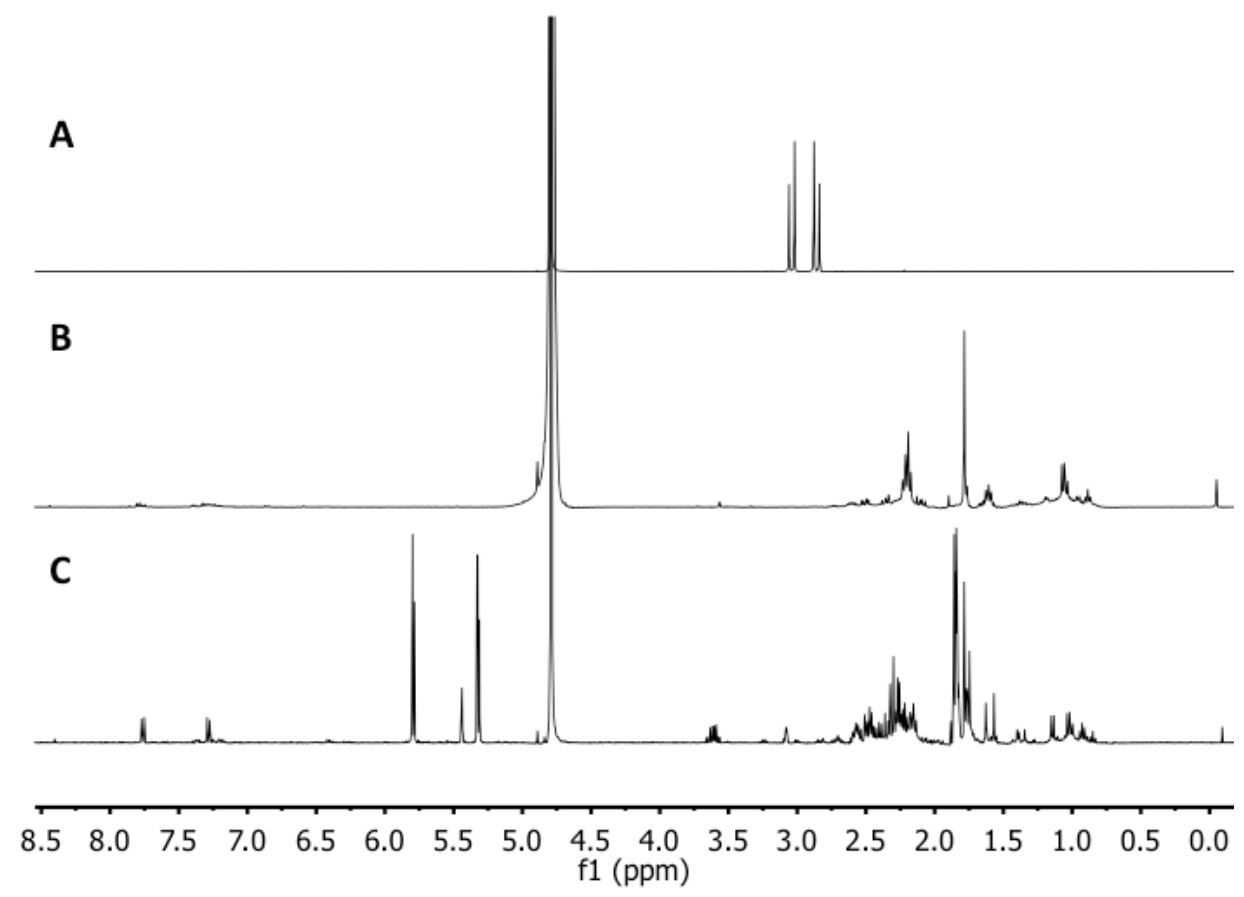

Appendix Figure 21: ${ }^{1} \mathrm{H}$ NMR in $\mathrm{D}_{2} \mathrm{O}$ of A) citric acid B) CQDs after 5 hours of heating at $180^{\circ} \mathrm{C}$ and $\mathrm{C}$ ) CQDs after 24 hours of heating at $180^{\circ} \mathrm{C}$. 


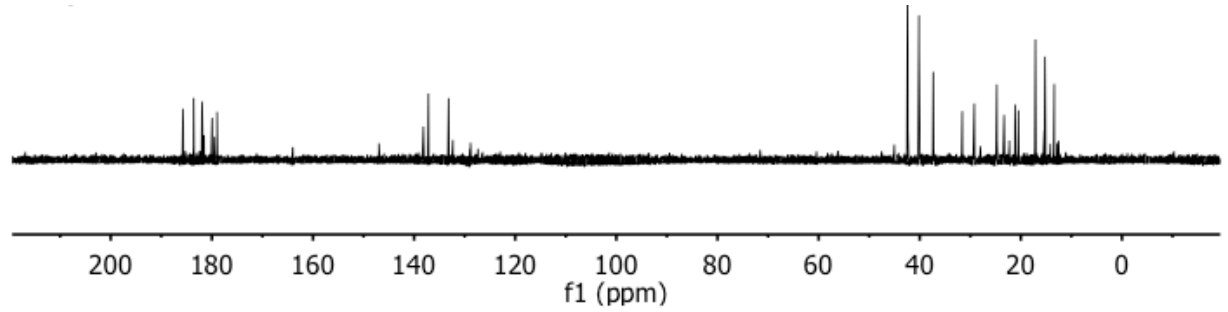

Appendix Figure 22: ${ }^{13} \mathrm{C}$ NMR in $\mathrm{H}_{2} \mathrm{O}$ of CQDs after 24 hours of heating at $180^{\circ} \mathrm{C}$. 


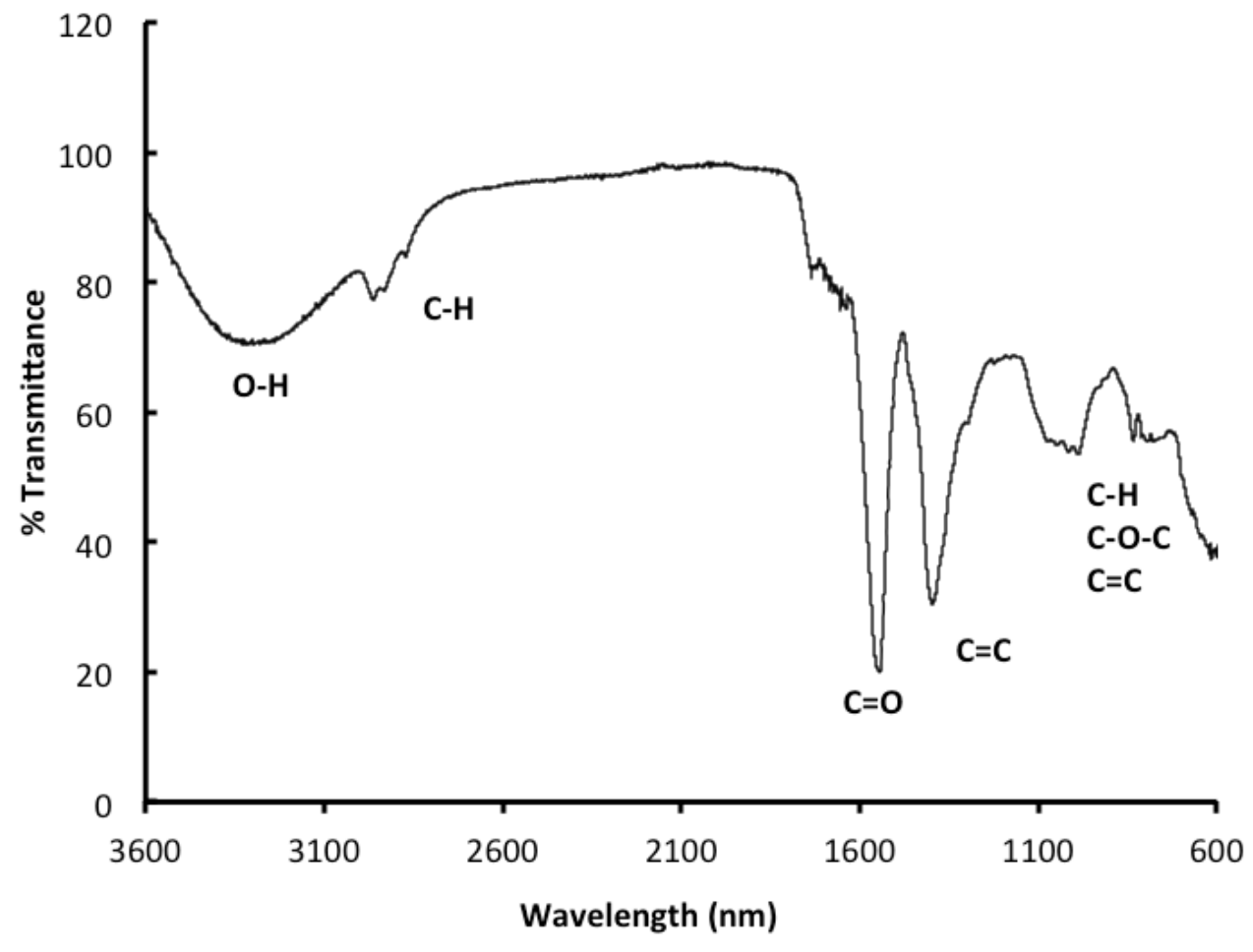

Appendix Figure 23: FTIR spectrum of uncoated CQDs. 


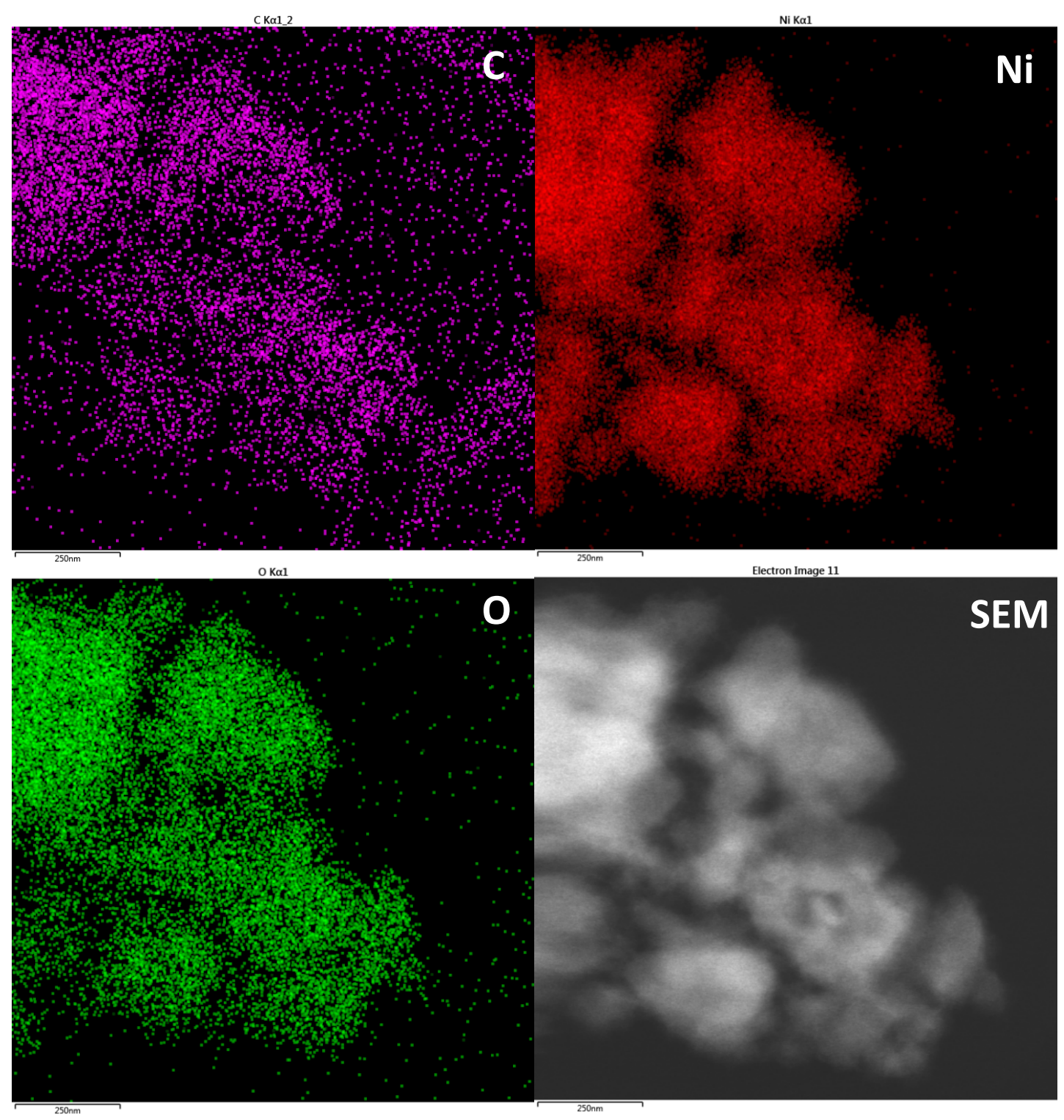

Appendix Figure 24: Electron Dispersive X-Ray (EDX) mapping of NiNP microstructures (coated with PVP). All scale bars are $250 \mathrm{~nm}$. 
Appendix Table 3: Change in QY as excitation wavelength is shifted bathochromically.

\begin{tabular}{|l|l|l|l|l|l|l|l|l|l|}
\hline & $360 \mathrm{~nm}$ & $380 \mathrm{~nm}$ & $400 \mathrm{~nm}$ & $420 \mathrm{~nm}$ & $440 \mathrm{~nm}$ & $460 \mathrm{~nm}$ & $480 \mathrm{~nm}$ & $500 \mathrm{~nm}$ & $520 \mathrm{~nm}$ \\
\hline$\Phi$ & $4.8 \%$ & $3 \%$ & $2.5 \%$ & $2.4 \%$ & $1.6 \%$ & $1.2 \%$ & $1.0 \%$ & $0.4 \%$ & $0.1 \%$
\end{tabular}



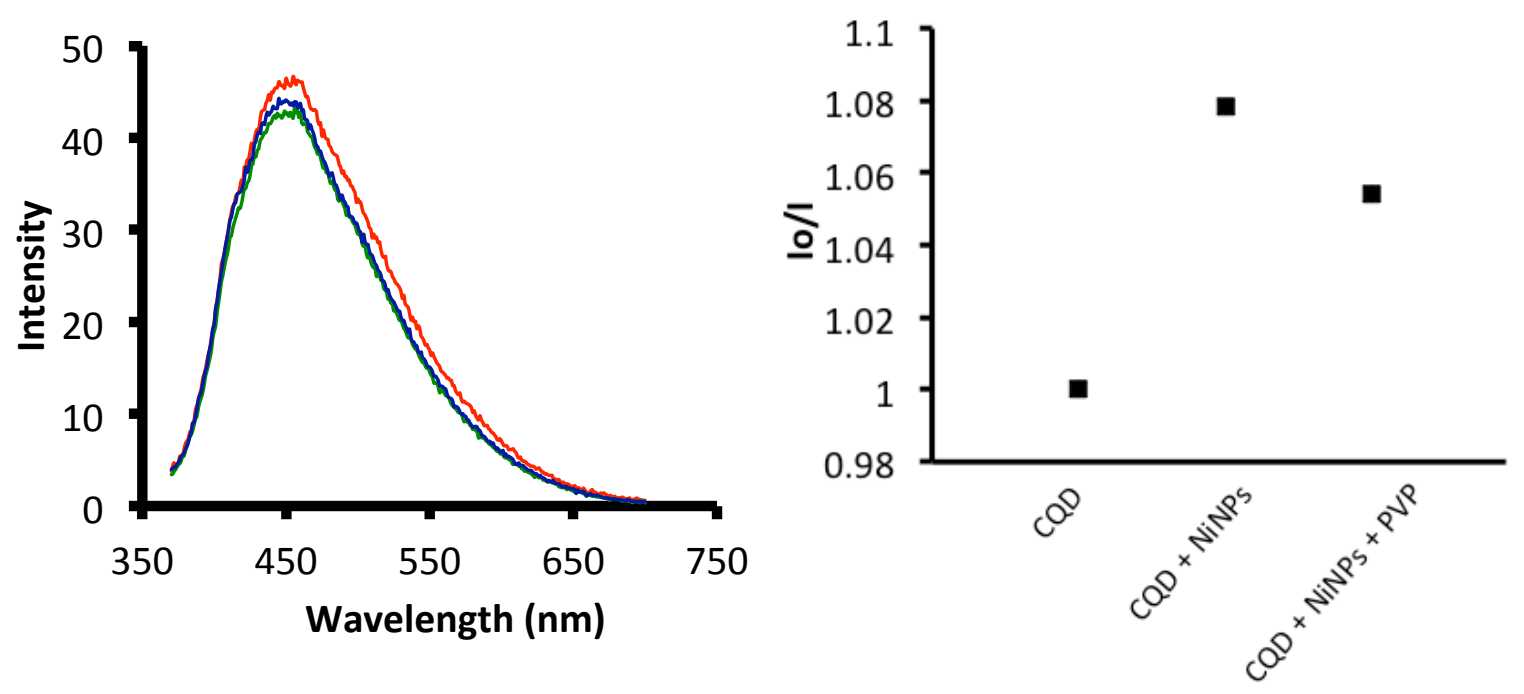

Appendix Figure 25: A) Emission spectrum of CQDs $(68 \mu \mathrm{g} / \mathrm{mL})$ with excitation at 360 $\mathrm{nm}$ (red). Emission spectrum showing decrease in emission following addition of $100 \mu \mathrm{L}$ NiNPs $(6 \mu \mathrm{g} / \mathrm{mL})$ (green) and subsequent spectrum showing increase in emission following addition of $500 \mu \mathrm{L}$ of a $1.0 \times 10^{-3} \mathrm{M}$ PVP solution (blue). All solutions are in 1:1 $\mathrm{H}_{2} \mathrm{O} / \mathrm{EtOH}$. B) Plot of $\mathrm{I}_{0} / \mathrm{I}$ using $\lambda_{\max }$ of the CQDs as $\mathrm{I}_{0}$ and $\lambda_{\max }$ as I following the addition of NiNPs and PVP. 

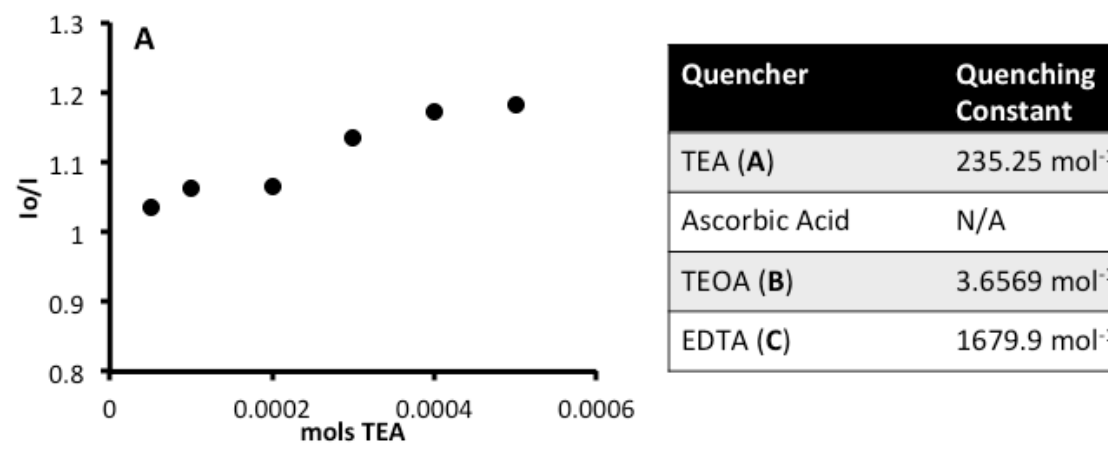

\begin{tabular}{|ll|}
\hline TEA (A) & $235.25 \mathrm{~mol}^{-1}$ \\
\hline Ascorbic Acid & N/A \\
\hline TEOA (B) & $3.6569 \mathrm{~mol}^{-1}$ \\
\hline EDTA (C) & $1679.9 \mathrm{~mol}^{-1}$ \\
\hline
\end{tabular}
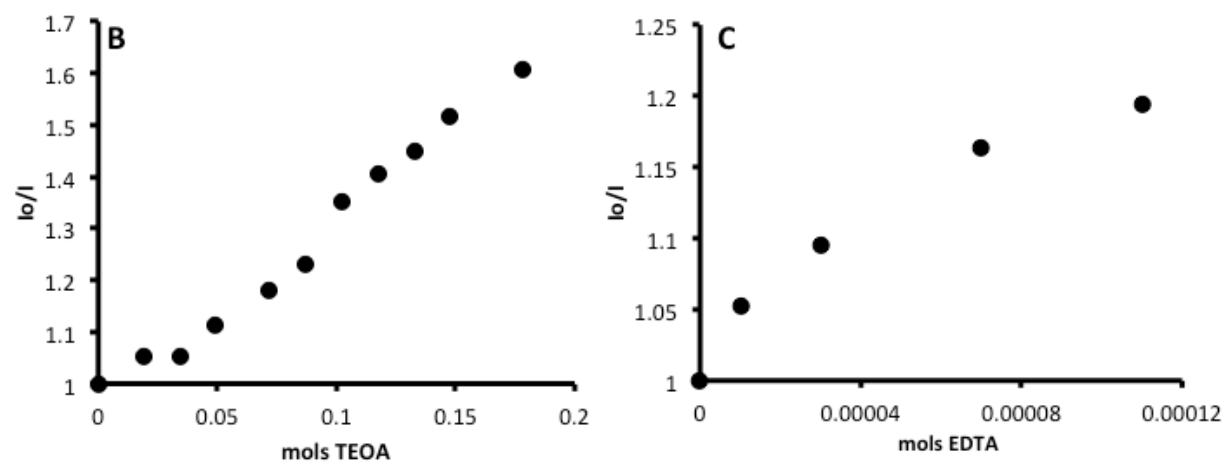

Appendix Figure 26: Change in emission intensity $\left(\mathrm{I}_{0}\right)$ of CQDs as a function of added quencher, $\mathrm{I}_{0} / \mathrm{I}$ vs mols of quencher for A) TEA, B) AA (N/A) C) TEOA, and D) EDTA. 

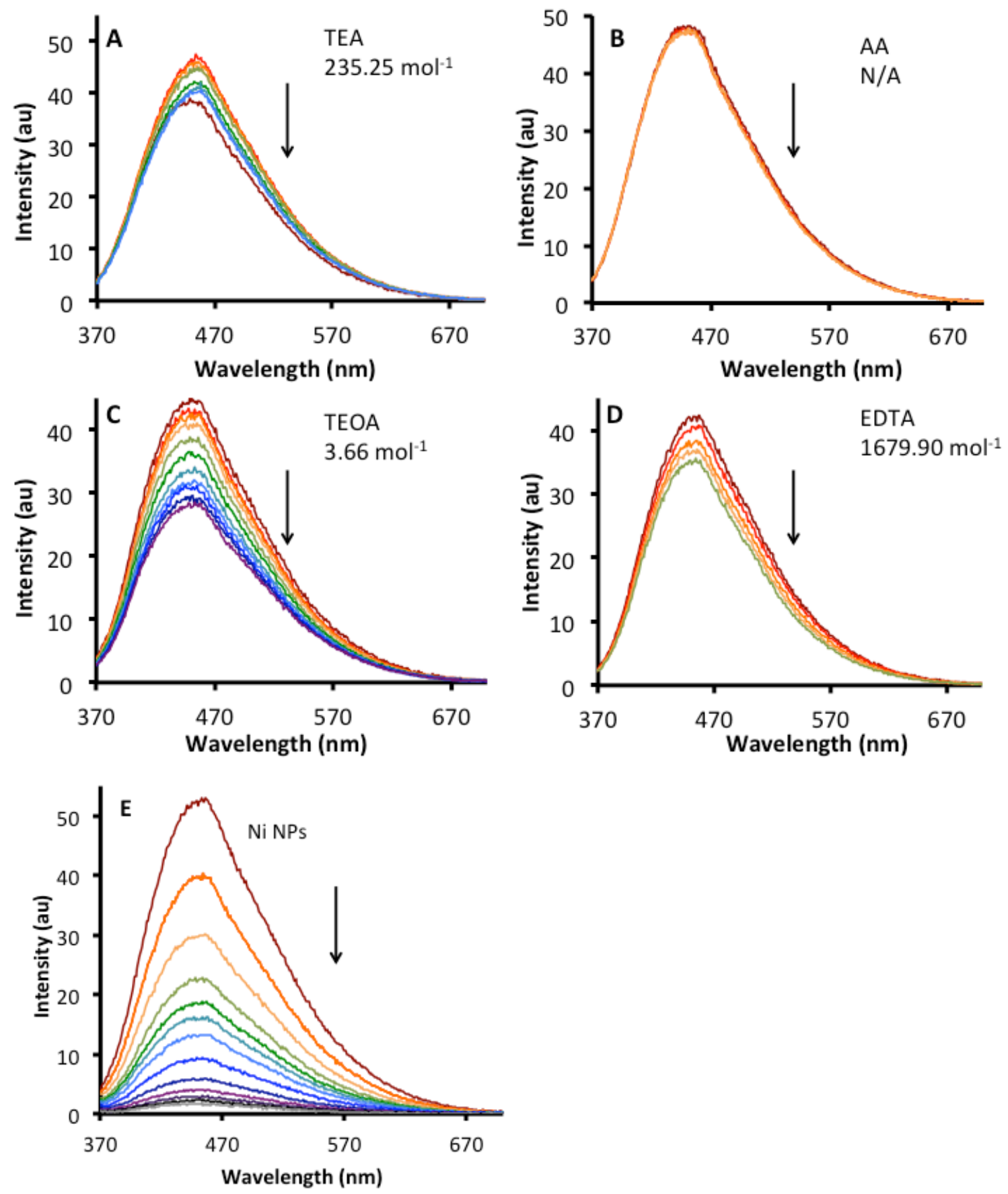

Appendix Figure 27: CQD emission quenching (4 mg CQD in $10 \mathrm{~mL}$ 1:1 $\mathrm{H}_{2} \mathrm{O} / \mathrm{EtOH}$ ) using A) TEA, $50 \mu \mathrm{mol}$ aliquots B) AA, $1 \mu \mathrm{mol}$ aliquots C) TEAO, 19 mmol aliquots D) EDTA (10 $\mu$ mol additions) E) NiNPs (30 $\mu$ g additions). 


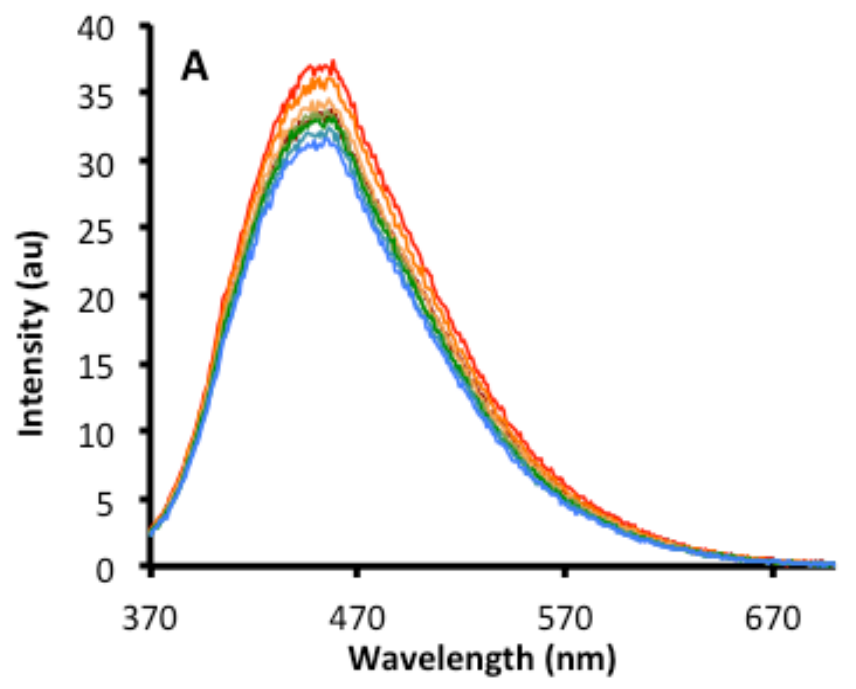

B

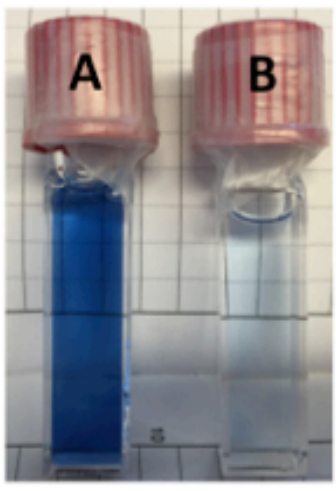

A) CQD, EDTA, MV

B) EDTA, MV

Appendix Figure 28: A) Quenching of CQD (4 mg in $\left.10 \mathrm{~mL} \mathrm{1:1} \mathrm{H}_{2} \mathrm{O} / \mathrm{EtOH}\right)$ emission by 0.01 mol aliquots of methyl viologen $B$ ) Reduction of methyl viologen by CQDs using $360 \mathrm{~nm}$ irradiation. 